DIVERSIDADE DE CIANOBACTÉRIAS NAS ÁREAS DA LAGOA DO CASAMENTO E DOS BUTIAZAIS DE TAPES E SEUS ECOSSISTEMAS ASSOCIADOS (RS, BRASIL)

Dissertação apresentada para obteção do título de Mestre em Microbiologia, área de Biologia e Sistemática de Microrganismos junto ao Programa de Pós-Graduação em Microbiologia do Instituto de Biociências, Letras e Ciências Exatas da Universidade Estadual Paulista "Júlio de Mesquita Filho”, Campus de São José do Rio Preto.

Orientador: Luis Henrique Zanini Branco

Co-orientadora: Vera Regina Werner

São José do Rio Preto, março de 2010 


\title{
DIVERSIDADE DE CIANOBACTÉRIAS NAS ÁREAS DA LAGOA DO CASAMENTO E DOS BUTIAZAIS DE TAPES E SEUS ECOSSISTEMAS ASSOCIADOS (RS, BRASIL)
}

\begin{abstract}
Dissertação apresentada para obteção do título de Mestre em Microbiologia, área de Biologia e Sistemática de Microrganismos junto ao Programa de Pós-Graduação em Microbiologia do Instituto de Biociências, Letras e Ciências Exatas da Universidade Estadual Paulista "Júlio de Mesquita Filho”, Campus de São José do Rio Preto.
\end{abstract}

Comissão Examinadora

Prof. Dr. Luis Henrique Zanini Branco

Professor Doutor

Universidade Estadual Paulista "Júlio de Mesquita Filho"

Prof $^{a}$. Dr ${ }^{\mathrm{a}}$. Maria Teresa de Paiva Azevedo

Professora Doutora

Instituto de Botânica de São Paulo

Prof. Dr. Carlos Eduardo de Mattos Bicudo

Professor Doutor

Instituto de Botânica de São Paulo 


\section{AGRADECIMENTOS}

Este trabalho é parte de um sonho que se realiza e o resultado de uma dedicação ao conhecimento das cianobactérias. Através da minha admiração pelo grupo de estudo, conheci pessoas que contribuíram grandemente para a conquista deste sonho. Além delas, outras pessoas também foram importantes, oferecendo suporte afetivo, indispensável para a superação dos obstáculos. A todas essas pessoas, gostaria de expressar meus sinceros agradecimentos.

Agradeço, em primeiro lugar, a Deus pela vida e por dirigir meus passos por caminhos tão gratificantes e prazerosos. Pelo Seu imenso amor e misericórdia, por ser meu auxiliador e principal fonte de conforto.

Ao meu orientador, Prof. Dr. Luis Henrique Zanini Branco, pela orientação, pelos ótimos ensinamentos e conselhos, e exemplo de dedicação e profissionalismo.

À minha co-orientadora, Dra. Vera Regina Werner, quem me apresentou o grupo das cianobactérias de maneira tão apaixonada que ficou impossível não me encantar por elas e por permitir o uso irrestrito de sua biblioteca. Pelo exemplo de competência, dedicação e postura científica, pela incansável disposição em me ensinar, pelos valiosos conselhos e pela inestimável amizade.

Ao Prof. Dr. Leandro Astarita e à Prof ${ }^{a}$. Dra. Eliane Santarém, do Laboratório de Biotecnologia Vegetal da Pontifícia Universidade Católica do Rio Grande do Sul, pelos valiosos ensinamentos e exemplo profissional, ainda tão vivos para mim.

Aos colegas e ex-colegas de laboratório, Nadia, Carmelia, Fernanda, Haruo, Jeferson e Pablo, por compartilharem comigo horas agradáveis durante o trabalho, pelas valiosas sugestões que contribuíram para o presente estudo, pelo apoio e carinho constantes.

Aos presidentes e diretores da Fundação Zoobotânica do Rio Grande do Sul e aos diretores do Museu de Ciências Naturais da FZB, por terem propiciado a infra-estrutura indispensável para a execução de parte desta pesquisa.

A toda minha família pelo incentivo e carinho.

Aos meus queridos pais, meus melhores exemplos de ética, pelo amor incondicional, apoio e auxílio, minha eterna gratidão, reconhecimento e admiração. Ao meu pai pelo 
exemplo de coragem, competência e caráter. À minha mãe, pelo afeto e exemplo de dedicação e perseverança.

Ao meu amado irmão, Guilherme, pelo apoio, força, companheirismo, carinho e momentos de descontração.

Ao meu amor, Guilherme, pelo apoio, paciência, carinho e compreensão perante minhas ausências em várias ocasiões.

Aos meus amados amigos, pela lealdade e carinho que sempre recebi de todos.

À Dona Marta Nunes e Paula Tozzato, a família que vim a conhecer e estimar, por me receberem tão bem em sua casa e terem feito eu me sentir acolhida, sempre com palavras de carinho e incentivo. 


\section{RESUMO}

As cianobactérias são dotadas de grande variabilidade morfológica e plasticidade ecológica e estão adaptadas aos mais diversos ambientes e regiões geográficas. O conhecimento taxonômico do grupo no Brasil ainda é restrito e concentrado principalmente no estado de São Paulo. Lagoas e banhados costeiros constituem hábitats de interesse científico, pois podem abrigar espécies não encontradas em outras condições ambientais e fornecer informações importantes do ponto de vista taxonômico, ecológico e evolutivo. A planície costeira do Rio Grande do Sul apresenta uma forte dominância de ecossistemas de áreas úmidas, destacandose entre eles, lagoas e lagunas de água doce e banhados. $\mathrm{O}$ objetivo deste estudo consiste no levantamento e estudo taxonômico das cianobactérias ocorrentes em ambientes aquáticos na área da lagoa do Casamento e ecossistemas associados, assim como na área dos butiazais (formação vegetal dominada pela palmeira butiá, Butia capitata (Martius) Beccari) nos arredores da cidade de Tapes. Os resultados obtidos baseiam-se na análise de 90 amostras de plâncton e espremidos de macrófitas que foram coletadas em maio, junho, outubro, novembro e dezembro de 2003, em 28 pontos das áreas (incluindo diferentes habitats como lagoas, banhados e sangradouro). Foram identificados 92 táxons específicos de cianobactérias, pertencentes a 39 gêneros. Synechococcophycidae foi representada por 34 espécies (37\%), Oscillatoriophycidae por 33 espécies (36\%) e Nostocophycidae por 25 espécies (27\%). Entre as espécies identificadas, 24 (26\%) são novas ocorrências para o Rio Grande do Sul. Três táxons foram identificados em nível genérico e provavelmente constituirão novos táxons para a ciência. Phormidium foi o gênero que apresentou o maior número de espécies identificadas (8), seguido de Aphanocapsa, Chroococcus e Oscillatoria (7 cada um). A espécie mais amplamente distribuída na região estudada foi Geitlerinema splendidum (Greville ex Gomont) Anagnostidis, ocorrendo em 11 corpos d'água, seguida de Phormidium tergestinum (Kützing) Anagnostidis et Komárek, que foi observada em 10. Das 92 espécies identificadas, 49 foram encontradas somente em lagoas, cinco somente em banhados, enquanto 38 foram observadas tanto em lagoas como em banhados. A maior riqueza específica foi registrada na área da lagoa do Casamento, com 48 espécies, enquanto na área dos butiazais foram registradas apenas 13 exclusivas espécies. Trinta e um táxons específicos tiveram ocorrência registrada tanto na área da lagoa do Casamento como na área dos butiazais em Tapes. 
ABSTRACT

Cyanobacteria have wide morphological diversity and ecological plasticity and are adapted to different environments and geographic regions. The taxonomic knowledge of the group in Brazil is still limited and it is mainly concentrated in the São Paulo State. Additionally, coastal lagoons and wetlands are habitats of scientific interest because they may harbor species not found in other environmental conditions and provide important information in terms of taxonomic, ecological and evolutionary. The coastal plain of the Rio Grande do Sul State has a strong dominance of wetland ecosystems, especially lakes and freshwater lagoons and marshes. The aim of this paper is the taxonomic study of the cyanobacteria in aquatic environments in the areas of Casamento lagoon and of the butiazais (vegetation mainly composed by the palm tree Butia capitata (Martius) Beccari) around Tapes City, as well as associated ecosystems. Results are based on the analysis of 90 samples obtained during the project "Assessment of the biodiversity of the Casamento lagoon and butiazais areas, coastal plain of Rio Grande do Sul State". Samples of plankton and squeezing submerged parts of aquatic macrophytes were collected in May, June, October, November and December 2003, in 28 sites (including different habitats such as ponds, wetlands and spillway). Ninety two specific taxa, belonging to 39 genera, were identified. Synechococcophycidae was represented by 34 species (37\%), Oscillatoriophycidae by 33 species (36\%) and Nostocophycidae, by 25 species (25\%). Among the identified species, 24 (26\%) are firstly recorded for Rio Grande do Sul State. Three taxa were identified only at generic level and are probably new to science. Phormidium was the genus which presented the highest number of identified species (8), followed by Aphanocapsa, Chroococcus and Oscillatoria (with 7 species each). Geitlerinema splendidum (Greville ex Gomont) Anagnostidis was the most widely distributed species, occurring in 11 water bodies, followed by Phormidium tergestinum (Kützing) Anagnostidis et Komárek, that occurred in 10. From the total amount of 92 identified species, 49 were found only in ponds, five were exclusive of wetlands, while 38 were observed occurring in both ponds and wetlands. The Casamento lagoon area presented the highest species richness, with 48 species, while the butiazais area presented only 13 species. Thirty one taxa were common for Casamento lagoon and butiazais of Tapes City areas. 


\section{SUMÁRIO}

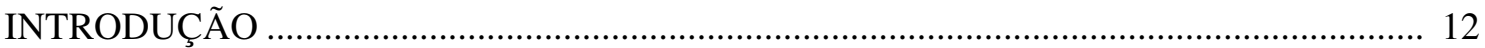

Cyanobacteria …………………………………………………………………. 12

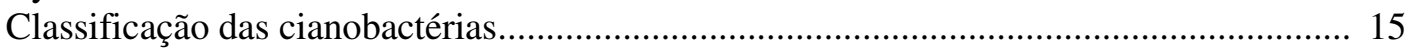

Diversidade de cianobactérias em lagoas e banhados ..................................................... 18

Planície costeira do Rio Grande do Sul ......................................................................... 20

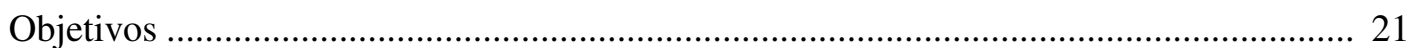

MATERIAL E MÉTODOS ........................................................................................... 22

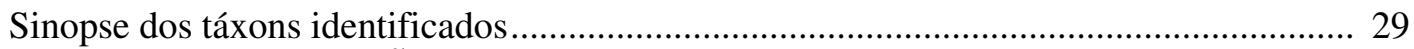

RESULTADOS E DISCUSS ÃO ……………………………………………………. 35

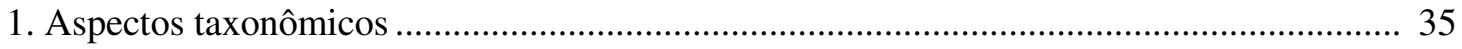

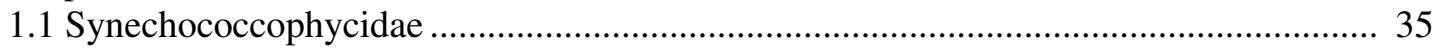

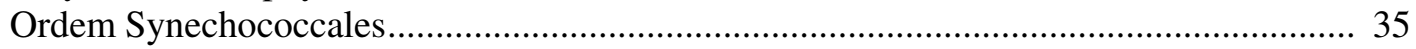

Chave para identificação das famílias encontradas......................................................... 35

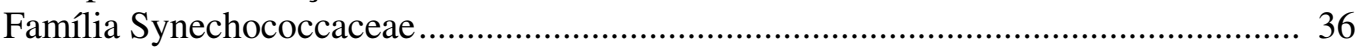

Subfamília Aphanothecoideae......................................................................... 36

Chave para identificação dos gêneros encontrados ............................................... 36

Aphanothece Nägeli ......................................................................................... 37

Chave para a identificação das espécies encontradas ........................................ 37

A. comasii Komárková-Legnerová ............................................................ 38

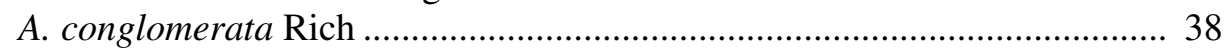

A. minutissima (W. West) Komárková-Legnerová et Cronberg ..................... 39

A. smithii Komárková-Legnerová et Cronberg .............................................. 40

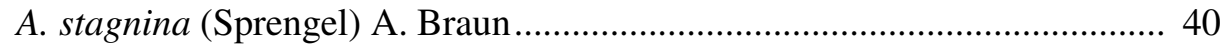

Cyanodictyon Pascher .......................................................................................... 43

Chave para identificação das espécies encontradas......................................... 43

C. reticulatum (Lemmermann) Geitler ........................................................ 43

C. tubiforme Cronberg ………………………………………………....... 44

Epigloeosphaera Komárková-Legnerová .............................................................. 45

Epigloeosphaera sp............................................................................... 45

Gloeothece Nägeli........................................................................................... 46

G. incerta Skuja ...................................................................................... 47

Família Merismopediaceae...................................................................................... 48

Chave para identificação das subfamílias encontradas ................................................ 49

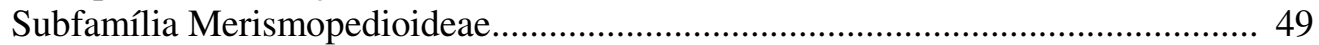

Chave para identificação dos gêneros encontrados ............................................... 49

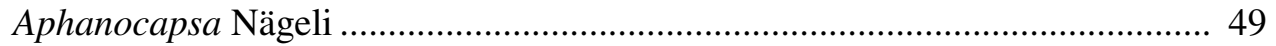

Chave para identificação das espécies encontradas......................................... 50

A. conferta (W. et G. S. West) Komárková-Legnerová .................................. 50

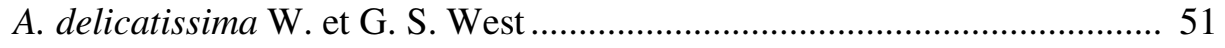

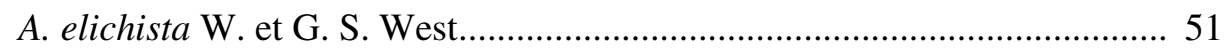

A. holsatica (Lermmermann) Cronberg et Komárek ………………………... 52

A. incerta (Lemmermann) Cronberg et Komárek ............................................ 52

A. cf. incerta (Lemmermann) Cronberg et Komárek ........................................ 53

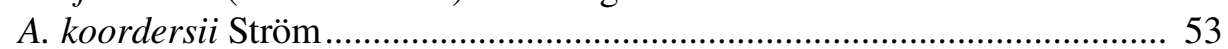

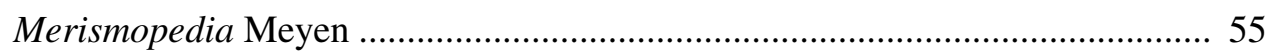

Chave para identificação das espécies encontradas.......................................... 55

M. elegans A. Braun in Kützing ………………………………………...... 56 


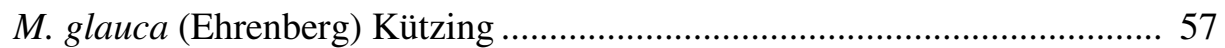

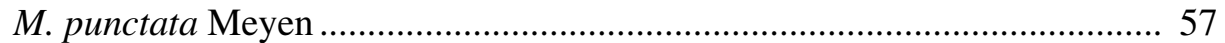

M. tenuissima Lemmermann.................................................................... 58

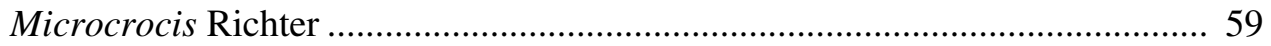

M. pulchella (Buell) Geitler ......................................................................... 59

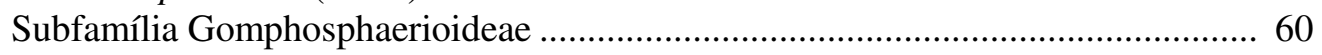

Chave para identificação dos gêneros encontrados .................................................6 60

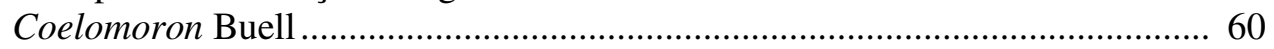

C. pusillum (Van Goor) Komárek................................................................... 61

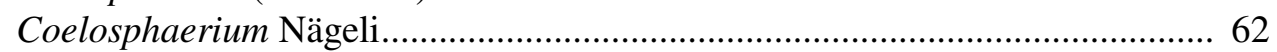

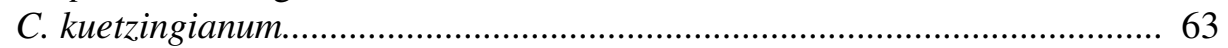

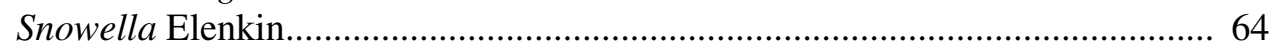

S. lacustris (Chodat)Komárek et Hindák ........................................................ 65

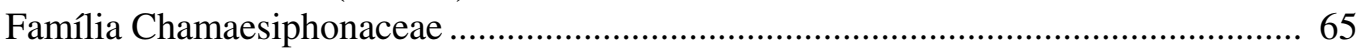

Chamaesiphon Braunt et Grunow ................................................................... 66

C. amethystinus (Rostafinski) Lemmermann ................................................ 67

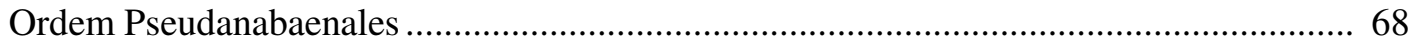

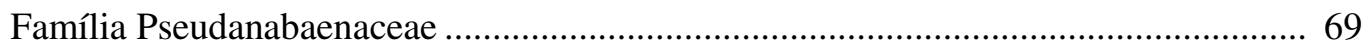

Chave para identificação das subfamílias encontradas ............................................... 70

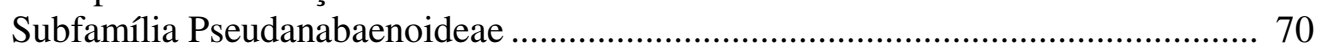

Chave para identificação dos gêneros encontrados ............................................ 70

Geitlerinema (Anagnostidis et Komárek) Anagnostidis ..................................... 70

Chave para identificação das espécies encontradas.......................................... 71

G. amphibium (Agardh ex Gomont) Anagnostidis ....................................... 71

G. splendidum (Greville ex Gomont) Anagnostidis...................................... 72

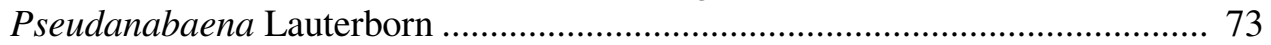

P. catenata Lauterborn.............................................................................. 73

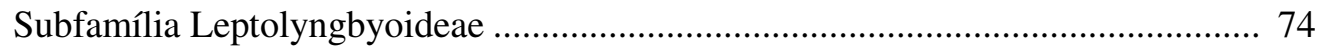

Chave para identificação dos gêneros encontrados ............................................... 74

Leptolyngbya Anagnostidis et Komárek ........................................................... 74

Chave para identificação das espécies encontradas......................................... 74

L. cebennensis (Gomont) Umezaki et M. Watanabe..................................... 75

L. lagerheimii (Gomont) Anagnostidis et Komárek ...................................... 75

L. perelegans (Lemmermann) Anagnostidis et Komárek ............................... 76

Planktolyngbya Anagnostidis et Komárek......................................................... 77

Chave para identificação das espécies encontradas.......................................... 78

P. contorta (Lemmermann) Anagnostidis et Komárek.................................. 78

P. limnetica (Lemmermann) Komárková-Legnerová et Cronberg ................. 79

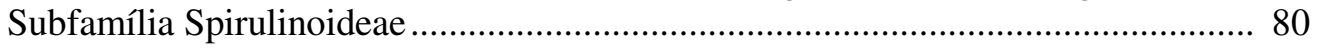

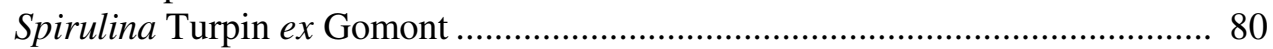

S. laxissima G. S. West f. major Desikachary .............................................. 81

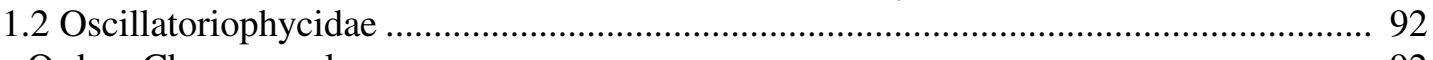

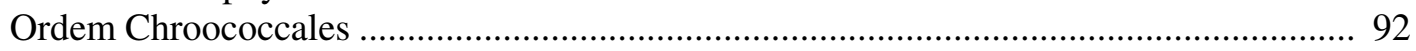

Chave para identificação das famílias encontradas ...................................................... 93

Família Microcystaceae ........................................................................................... 93

Chave para identificação dos gêneros encontrados .............................................. 93

Eucapsis Clement et Shantz ...................................................................... 94

E. parallelepipedon (Schmidle) Komárek et Hindák....................................... 94

Microcystis Kützing ex Lemmermann ............................................................. 95

Chave para identificação das espécies encontradas........................................ 95

M. aeruginosa (Kützing) Kützing ................................................................ 96

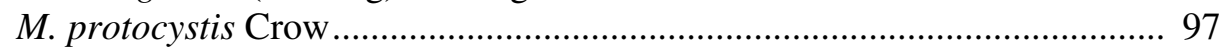

M. smithii Komárek et Anagnostidis............................................................ 97

M. wesenbergii (Komárek) Komárek in Kondrateva..................................... 98

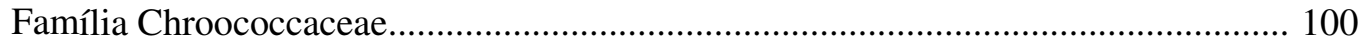




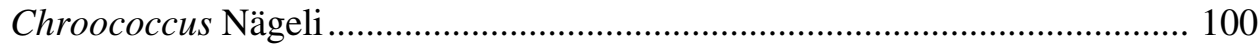

Chave para identificação das espécies encontradas......................................... 101

C. dispersus (Keissler) Lemmermann........................................................ 102

C. distans (G. M. Smith) Komárková-Legnerová et Cronberg..................... 102

C. limneticus Lemmermann ...................................................................... 103

C. microscopicus Komárková-Legnerová et Cronberg................................. 104

C. minimus (Keissler) Lemmermann ............................................................ 104

C. minutus (Kützing) Nägeli .................................................................... 105

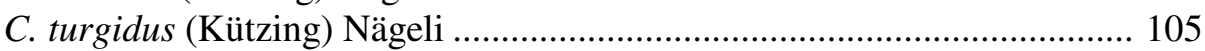

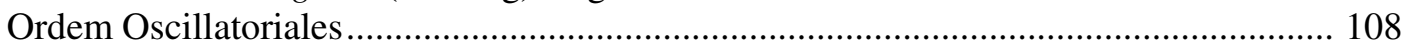

Chave para identificação das famílias encontradas.................................................... 109

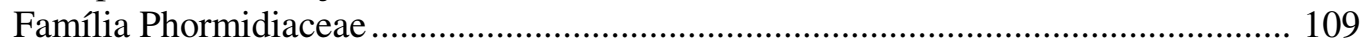

Chave para identificação das subfamílias encontradas ............................................. 110

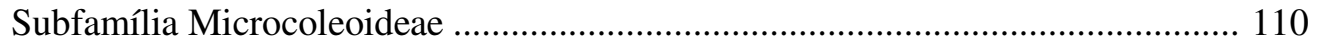

Microcoleus Desmazières ex Gomont............................................................ 110

Chave para identificação das espécies encontradas......................................... 110

M. lacustris (Rabenhorst) Farlow ex Gomont............................................... 110

M. subtorulosus Gomont ex Gomont ........................................................ 111

Subfamília Phormidioideae................................................................................. 112

Chave para identificação dos gêneros encontrados ............................................. 112

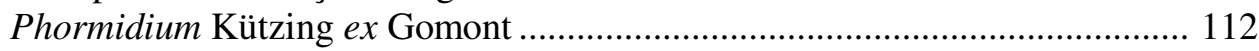

Chave para identificação das espécies encontradas......................................... 114

P. aerugineo-caeruleum (Gomont) Anagnostidis et Komárek ..................... 115

$P$. amoenum Kützing ex Anagnostidis et Komárek .................................... 115

P. autumnale (Agardh) Trevisan ex Gomont ............................................. 116

P. chalybeum (Mertens ex Gomont) Anagnostidis et Komárek.................... 117

P. formosum (Bory ex Gomont) Anagnostidis et Komárek .......................... 117

P. granulatum (Gardner) Anagnostidis........................................................ 118

P. hamelii (Frémy) Anagnostidis et Komárek ............................................ 119

P. tergestinum (Kützing) Anagnostidis et Komárek ..................................... 119

Planktothrix Anagnostidis et Komárek .......................................................... 122

Chave para identificação das espécies encontradas....................................... 122

P. agardhii (Gomont) Anagnostidis et Komárek.......................................... 123

P. isothrix (Gomont) Komárek et Komárková................................................. 123

Trichodesmium Ehrenberg ex Gomont......................................................... 124

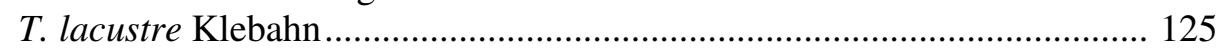

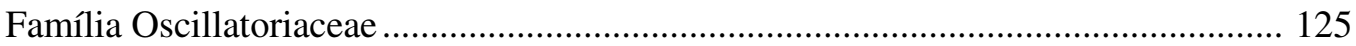

Chave para identificação dos gêneros encontrados ........................................... 126

Lyngbya Agardh ex Gomont ....................................................................... 127

L. martensiana Meneghini ex Gomont ....................................................... 127

Oscillatoria Vaucher ex Gomont .................................................................... 128

Chave para identificação das espécies encontradas......................................... 128

O. cf. anguina Bory ex Gomont ................................................................... 129

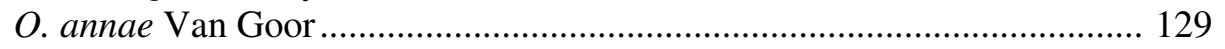

O. curviceps Agardh ex Gomont............................................................... 130

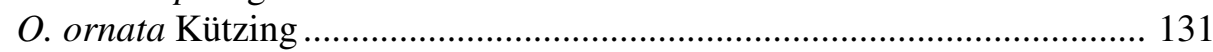

O. princeps Vaucher ex Gomont............................................................. 131

O. sancta Kützing ex Gomont................................................................ 132

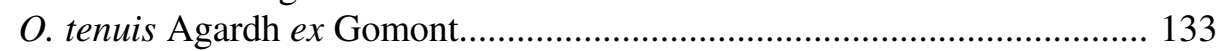

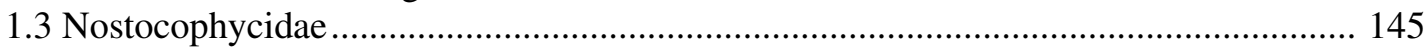

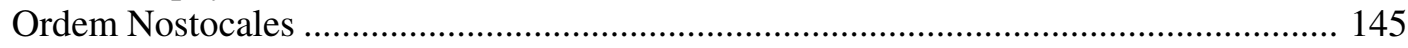

Chave para identificação das famílias encontradas ....................................................... 147

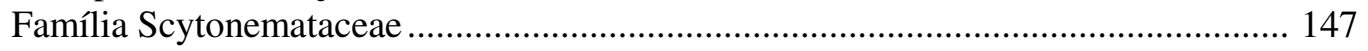

Scytonema Agardh ex Bornet et Flahault ......................................................... 148

S. mirabile (Dillwyn) Bornet .................................................................... 148 


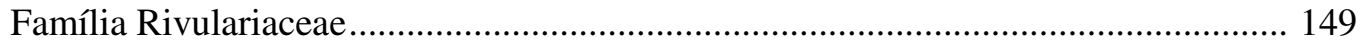

Chave para identificação dos gêneros encontrados ........................................... 149

Calothrix Agardh ex Bornet et Flahault .......................................................... 150

Chave para identificação das espécies encontradas......................................... 150

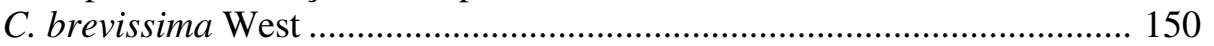

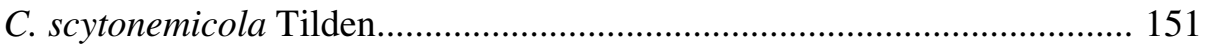

Gloeotrichia Agardh ex Bornet et Flahault................................................... 151

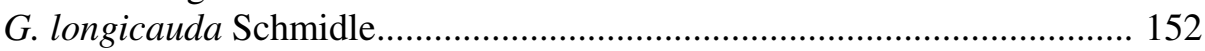

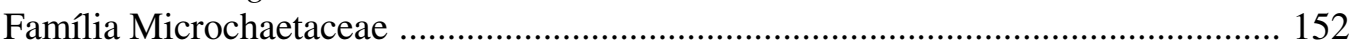

Microchaete Thuret ex Bornet et Flahault....................................................... 153

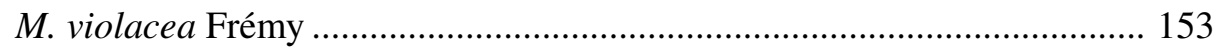

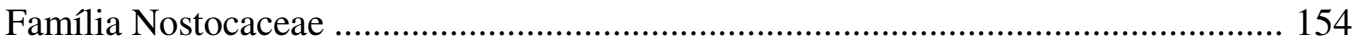

Chave para identificação das subfamílias encontradas ......................................... 155

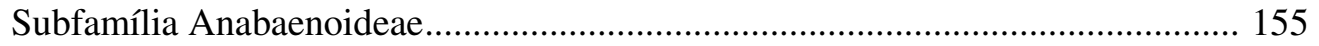

Chave para identificação dos gêneros encontrados ............................................. 155

Anabaena Bory ex Bornet et Flahault ............................................................. 156

Chave para identificação das espécies encontradas........................................ 157

A. inaequalis (Kützing) Bornet et Flahault ................................................... 157

A. oscillarioides Bory ex Bornet et Flahault ................................................ 158

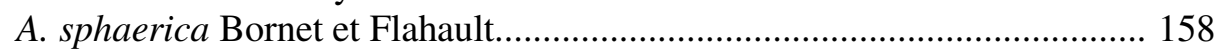

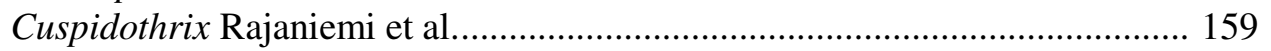

C. issatschenkoi (Usacev) Rajaniemi et al................................................ 160

Cylindrospermopsis (Wolosynska) Seenayya et Subba Raju .......................... 160

C. raciborskii (Wolosynska) Seenayya et Subba Raju ................................. 161

Cylindrospermum Kützing ex Bornet et Flahault.............................................. 162

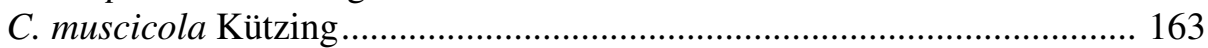

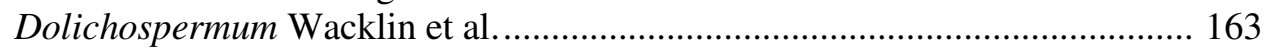

Chave para identificação das espécies encontradas....................................... 164

D. crassum (Lemmermann) Wacklin et al................................................. 164

D. flos-aquae (Lyngbye) Wacklin et al....................................................... 165

D. spiroides (Klebahn) Wacklin et al........................................................... 166

D. planctonicum (Brunnthaler) Wacklin et al............................................ 167

D. cf. solitarium (Klebahn) Wacklin et al................................................. 168

D. viguieri (Denis et Frémy) Wacklin et al................................................... 169

Hydrocoryne Schwabe ex Bornet et Flahault ................................................ 170

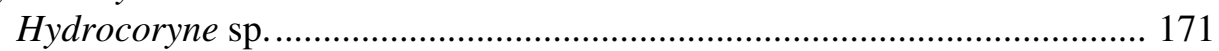

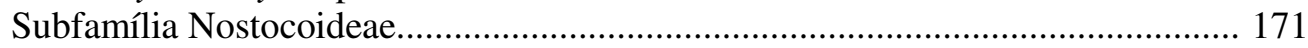

Chave para identificação dos gêneros encontrados ............................................. 171

Aulosira Kirchner ex Bornet et Flahault ....................................................... 172

A. laxa Kirchner ex Bornet et Flahault........................................................ 172

Nostoc Vaucher ex Bornet et Flahault............................................................ 173

Chave para identificação das espécies encontradas......................................... 174

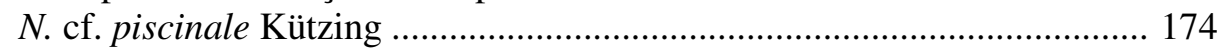

N. spongiaeforme Agardh ........................................................................ 174

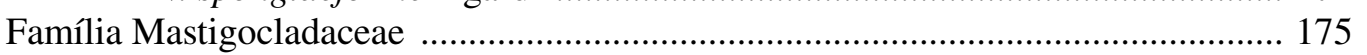

Hapalosiphon Nägeli ex Bornet et Flahault .............................................. 176

Chave para identificação das espécies encontradas ............................................. 176

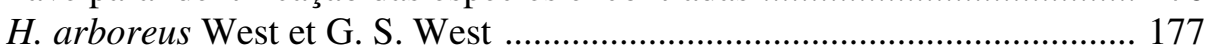

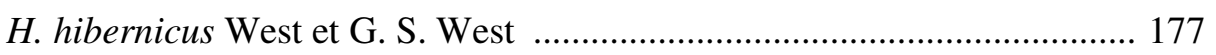

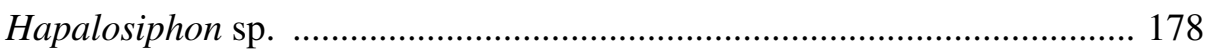

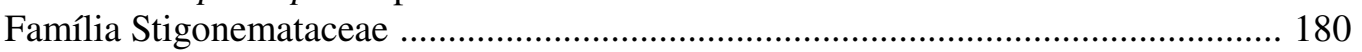

Stigonema Agardh ex Bornet et Flahault ................................................... 180

S. ocellatum (Dillwyn) Thuret ex Bornet et Flahault .................................. 181

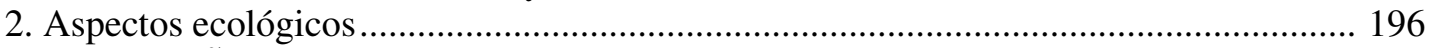

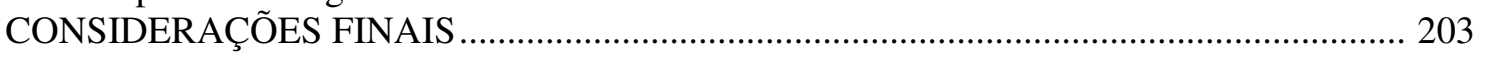


REFERÊNCIAS BIBLIOGRÁFICAS 205

ÍNDICE ALFABÉTICO DOS TÁXONS ESPÉCÍFICOS IDENTIFICADOS 


\section{INTRODUÇÃO}

\section{CYANOBACTERIA}

As cianobactérias constituem um grupo filogeneticamente coeso dentro do domínio Bacteria. São os mais antigos organismos fotossintetizantes produtores de oxigênio, tendo desempenhado um papel crítico na introdução de $\mathrm{O}_{2}$ na atmosfera e no desenvolvimento do mecanismo de produção primária de matéria orgânica no planeta (WHITTON \& POTTS, 2000b).

Estudos com fósseis encontrados no Canadá, por S. A. Tyler e E. S. Barghoorn em 1964, e na Austrália, por E. S. Barghoorn e J. W. Schopf em 1965, indicam que a história evolutiva das cianobactérias teve início há 3,5 bilhões de anos, no Eon Arqueano (SCHOPF, 2000; SCHOPF \& WALTER, 1982). No entanto, os relatos fósseis mais abundantes provêm do Proterozoico, quando todos os grupos dentro das cianobactérias estavam presentes, recebendo de Schopf \& Walter (1982) a denominação de "Idade das Cianobactérias".

A longa história evolutiva conferiu aos membros do grupo a capacidade para colonizar os mais variados tipos de hábitats. Ocorrem nos ambientes aquáticos de água doce, lênticos ou lóticos, podendo fazer parte de comunidades planctônicas, bentônicas, metafíticas e perifíticas (WHITTON \& POTTS, 2000a). Ocupam os mais variados tipos de solos, podendo desempenhar papel importante em estágios iniciais do processo de sucessão primária no solo, principalmente em regiões de vegetação escassa como desertos, semidesertos e regiões polares. Vivem em ambientes subaéreos como rochas e troncos de árvores (FRÉMY, 1930; DESIKACHARY, 1959) e em ambientes extremos como águas termais (MILLER, 2007), ambientes marinhos, hipersalinos, áridos (WHITTON \& POTTS, 2000a).

A origem antiga, de adaptação a um ambiente extremo e dinâmico como era a Terra no passado, talvez tenha favorecido o desenvolvimento da grande plasticidade fisiológica exibida pelo grupo. As cianobactérias também têm importância evolutiva em relação às plantas, pois é cada vez mais aceita a teoria de que originaram os cloroplastos das plantas por endossimbiose (GIOVANNONI et al., 1988; RAVEN \& ALLEN, 2003).

São procariontes gram-negativos e, assim como as algas e as plantas, possuem clorofila $a$, uma das características que as distingue das demais bactérias fotossintetizantes 
(GRAHAM \& WILCOX, 2000). Três gêneros, Prochloron Lewin, Prochlorococcus Chisholm et al. e Prochlorothrix Buger-Wiersma, Stal e Mur, apresentam clorofila $a$ e $b$ (BURGER-WIERSMA et al., 1989; URBACH et al., 1992) e um, Acaryochloris Miyashita et Chihara, possui clorofila $a$ e $d$ (MIYASHITA et al., 1996). Além de clorofila, os demais pigmentos que participam da fotossíntese em cianobactérias são xantofilas, $\beta$-caroteno e ficobiliproteínas (ficoeritrina, ficocianina e aloficocianina), todos eles organizados nos tilacoides, que são membranas lipoproteicas distribuídas no citoplasma. Acumulam cianoficina, uma substância de reserva semelhante ao glicogêneo, e reproduzem-se apenas assexuadamente e não possuem elementos móveis em nenhuma fase de desenvolvimento.

Algumas cianobactérias produzem células especializadas na fixação de nitrogênio (heterócitos), células que auxiliam na sobrevivência quando sob condições de estresse (acinetos) e na dispersão (hormogônios).

Algumas apresentam a propriedade de flutuação, conferida pela capacidade de produzir aerótopos, estruturas proteicas que armazenam ar e possibilitam o deslocamento do organismo na coluna d'água.

Formam um grupo de grande diversidade fisiológica, sendo capazes de realizar metabolismo anaeróbico e muitos grupos dentro de Cyanobacteria compartilham com bactérias fototróficas a habilidade de realizar fotossíntese anoxigênica, utilizando $\mathrm{H}_{2} \mathrm{~S}$ como doador de elétrons (PADAN \& COHEN, 1982; COHEN et al., 1986; GARCIA-PICHEL \& CASTENHOLZ, 1990). E compartilham com muitas arqueobactérias a habilidade de usar o elemento enxofre na respiração anaeróbica (OREN \& SHILO, 1979).

As cianobactérias exibem grande diversidade morfológica ocorrendo desde formas unicelulares que se reproduzem por fissão binária, até formas filamentosas complexas, que possuem uma variedade de células diferenciadas, algumas das quais podem formar ramificações verdadeiras (WHITTON \& POTTS, 2000b). Quanto ao tamanho, as células podem variar desde o típico tamanho bacteriano $(0,5-1 \mu \mathrm{m})$ até células consideradas grandes, com $100 \mu \mathrm{m}$. Embora não possuam elementos móveis como flagelos e cílios, muitas espécies apresentam movimentos de deslizamento que, embora não se compreenda o mecanismo, acredita-se que aconteça devido à extrusão de mucilagem através de poros e à presença de fibrilas localizadas externamente à parede celular (HOICZYK \& BAUMEISFER, 1995).

Trata-se de um grupo ecologicamente importante sob vários aspectos. Alguns organismos formam relações simbióticas com plantas, fungos, esponjas e protistas (ADAMS, 2000). Somente as cianobactérias, além de algumas outras poucas bactérias, são capazes de fixar nitrogênio atmosférico. Essa capacidade confere ao grupo importância na área da agricultura, 
enriquecendo o solo a partir da liberação de substâncias como o nitrato e o oxigênio, agindo como fertilizantes e, por consequência, aumentando a produtividade. As tentativas de melhorar o rendimento de culturas, pela adição de cianobactérias no solo, são mais comuns em plantações de arroz (WHITTON, 2000) e, embora muitos estudos mostrem os efeitos positivos do uso das cianobactérias em culturas, são poucos os locais onde essa vantagem é explorada.

As cianobactérias têm importância também na caracterização do solo onde ocorrem. A produção de polissacarídeos extracelulares auxilia na agregação das partículas do solo, protegendo-o contra erosão (FALCHINI et al., 1996).

Muitas espécies possuem alto valor nutricional, sendo fonte de proteínas e vitaminas. $\mathrm{Na}$ indústria, Arthrospira (comercialmente Spirulina) é um dos gêneros mais importantes dentre os cultivados, sendo utilizado principalmente como suplemento alimentar (VONSHAK \& TOMASELLI, 2000).

Embora alguns táxons exibam uma amplitude de tolerância grande, adaptando-se a condições ambientais distintas, outros podem ser considerados bioindicadores, sendo característicos de determinados ambientes. Enquanto algumas espécies são adaptadas a ambientes limpos, outras são características de ambientes poluídos e muitas espécies ainda, podem ser encontradas tanto em ambientes poluídos como não poluídos.

O grupo engloba organismos que, cada vez mais, apresentam destaque, principalmente em águas continentais, ora por sua dominância no ambiente, podendo ocasionar, por este fato, problemas de saúde pública e de abastecimento, ora por sua importância inequívoca devido à potencial toxicidade (GRAHAM \& WILCOX 2000).

O constante aumento no número de corpos d'água eutrofizados está proporcionando condições para a ocorrência de florações de cianobactérias que normalmente causam alterações na coloração, sabor e cheiro das águas, além de poderem conferir toxidez às mesmas. Muitos casos de intoxicação causados pelo consumo de água contendo cianobactérias tóxicas e/ou seus produtos já foram documentados (BERG et al., 1987; NEHRING, 1993; KIM et al., 1995; ONODERA et al., 1997; VEZIE et al., 1997; VASCONCELOS, 1999; KAAS \& HENRIKSEN, 2000; VIEIRA et al., 2003; YUAN et al., 2006).

As cianotoxinas podem ser classificadas em peptídeos cíclicos, lipopolissacarídeos e alcaloides, de acordo com a sua estrutura química (CHORUS \& BARTRAM, 1999), ou em citotoxinas, dermatotoxinas, hepatotoxinas e neurotoxinas, de acordo com o seu modo de ação (SIVONEN \& JONES, 1999). As citotoxinas, como a cilindrospermopsina, atuam inibindo a síntese proteica, podendo causar danos ao fígado, rins e tecido linfoide. As dermatotoxinas são lipopolissacarídeos, pigmentos ou compostos de parede celular, que podem causar irritação nos 
olhos, pele, febre, fadiga, tontura e gastrenterite. As hepatotoxinas, peptídeos cíclicos como microcistinas e nodularinas, inibem as fosfatases dos tipos 1 e 2A, causando desnaturação das proteínas no fígado e o aparecimento de tumores hepáticos. As neurotoxinas, alcaloides como anatoxinas, saxitoxinas e goniautoxinas, inibem as transmissões neuromusculares, causando paralisia progressiva, respiração abdominal forte, cianose, convulsão e morte por asfixia (CHORUS \& BERTRAM, 1999).

Apesar dos problemas ambientais e de saúde pública causados por esses organismos, também devem ser considerados os benefícios oferecidos por eles, como a inegável importância ecológica que desempenham, seu uso em biodegradação e biorremediação (DUMANS, 1988; SHASHIREKHA et al., 2005; PANDI et al., 2009), além de serem utilizados no desenvolvimento de produtos farmacológicos (BOROWITZKA, 1995; KREITLOW et al., 1999).

Mesmo com a reconhecida importância ecológica, o conhecimento taxonômico do grupo concentra-se principalmente nos países na Europa, sendo pouco conhecida a diversidade do grupo na América do Sul e, por consequência, no Brasil, sendo que a flora é mais bem conhecida na região sudeste do Brasil (BICUDO \& BICUDO (1969), OLIVEIRA (1976), SENNA (1979, 1982), BAETA NEVEZ (1983, 1991, 1992), SANT’ANNA (1984, 1888, 1991, 1997), HUSZAR et al. (1989), SANT'ANNA et al. (1983, 1985, 1989, 1991, 1995), SENNA \& PEREIRA (1986), AZEVEDO (1991), BRANCO (1991), HUSZAR \& SILVA (1992), SANT’ ANNA \& AZEVEDO (1995), AZEVEDO et al. (1996), BRANCO et al. (1996, 1997, 1999)). Na região sul, poucos estudos taxonômicos sobre cianobactérias foram realizados no estado do Rio Grande do Sul e resumem-se aos de Torgan et al. (1981), Torgan \& Paula (1994), Franceschini (1983, 1990), Werner (1984, 1988, 2002), Werner \& Rosa (1992) e Werner \& Sant'Anna (1998, 2000), sendo esses seis últimos, específicos sobre organismos provenientes de lagoas ou lagunas costeiras do estado.

\section{CLASSIFICAÇÃO DAS CIANOBACTÉRIAS}

Um sistema de classificação taxonômica é um método de registro da biodiversidade na Terra em grupos taxonômicos e deve refletir as relações evolutivas (WILMOTTE \& GOLUBIC, 1991; KOMÁREK, 2003b; HOFFMANN et al., 2005).

Tradicionalmente, os sistemas de classificação das cianobactérias eram baseados exclusivamente em dados morfológicos, em que essas eram classificadas como algas azuis (Cyanophyta) entre as algas eucarióticas, sob o código de nomenclatura botânica. Desde o primeiro 
registro desses organismos, feito por Christian Gottfried Ehrenberg (EHRENBERG, 1838), muitos sistemas de classificação foram propostos.

Os trabalhos de Thuret (1875), Bornet \& Flahault (1886-1888) e Gomont (1892) foram os primeiros que apresentaram descrições taxonômicas de cianobactérias. Ainda baseadas apenas em dados morfológicos e seguindo os moldes botânicos, as obras de Bornet \& Flahault (1886-1888) e Gomont (1892) foram indicadas como pontos de partida nomenclatural ("nomenclatural starting points") para as formas filamentosas heterocitadas e homocitadas, respectivamente.

Outros trabalhos foram desenvolvidos posteriormente são também de grande importância para a sistemática do grupo. A publicação mais conhecida é a de Geitler (1932) que, por meio do estudo da diversidade de cianobactérias, principalmente da Europa Central, apresentou aproximadamente 1300 espécies de cianobactérias distribuídas em 145 gêneros, 20 famílias e 3 ordens. Em seu estudo, além das características morfológicas e métricas, foram considerados também os aspectos ecológicos. Outros trabalhos importantes foram realizados de maneira semelhante ao de Geitler (1932), como Frémy (1929-1933, 1930), Elenkin (1935, 1938-1949), Geitler (1942), Desikachary (1959), Starmach (1966) e Bourrelly (1970a).

As publicações de Drouet \& Daily (1956) e de Drouet $(1968,1973,1978,1981)$ trouxeram outra proposta de classificação para as cianobactérias. Nesse sistema, denominado Drouetiano, as mais de 2000 espécies descritas até então foram reduzidas a 62 espécies pertencentes a 24 gêneros. Essa redução no número de espécies e gêneros, baseou-se na hipótese de que a maioria das espécies de cianobactérias tratava-se, na verdade, de variações fenotípicas do mesmo genótipo, como resposta a fatores ambientais.

A partir do momento em que se observou que o grupo possuía estrutura celular característica de procariontes, Stanier et al. (1978) propuseram que a nomenclatura das cianobactérias fosse regida pelo código bacteriológico e, em 1979, Rippka et al. criaram uma classificação bacteriológica para esses organismos. Tal classificação foi modificada e incluída no "Bergey’s Manual of Bacteriology" (BOONE et al., 2001), que é uma das obras mais importantes sobre diferentes grupos de bactérias e amplamente aceita pela comunidade de microbiologistas, embora não seja o documento oficial da classificação bacteriológica.

Atualmente, segundo o "Bergey's Manual”, Cyanobacteria inclui as proclorófitas e as cianobactérias e é dividida em cinco subseções (CASTENHOLZ, 2001), baseado principalmente no tipo de talo, no tipo de reprodução, na capacidade de produzir células diferenciadas e na formação de ramificações verdadeiras.

Subseção I: talo unicelular ou pseudofilamentoso, reprodução por fissão binária em 1 ou mais planos; 
Subseção II: talo unicelular ou pseudofilamentoso, reprodução por fissão múltipla ou em combinação com fissão binária;

Subseção III: talo filamentoso homocitado, reprodução por hormogônios e hormocitos;

Subseção IV: talo filamentoso heterocitado, reprodução por hormogônios e hormocitos, sem ramificações verdadeiras;

Subseção V: talo filamentoso heterocitado, reprodução por hormogônios e hormocitos, com ramificações verdadeiras.

Konstantinos Anagnostidis e Jiri Komárek revisaram a classificação das cianobactérias sob os parâmetros botânicos (ANAGNOSTIDIS \& KOMÁREK, 1985; 1990; KOMÁREK \& ANAGNOSTIDIS, 1989; 1998; 2005) e, no trabalho publicado em 1985, dividiram o grupo em quatro ordens, Chroococcales, Oscillatoriales, Nostocales e Stigonematales. A partir de uma extensa revisão, utilizando critérios morfológicos, bioquímicos, ecológicos, ultraestruturais e moleculares, esses autores elaboraram um sistema de classificação onde as cianobactérias estão organizadas em ordens, famílias e gêneros e cujos agrupamentos taxonômicos estão baseados principalmente no padrão de divisão celular, forma celular, organização das células na bainha ou envelope mucilaginoso.

Nostocales: talo filamentoso heterocitado, reprodução por hormogônios e hormocitos, sem ramificações verdadeiras;

Stigonematales: talo filamentoso heterocitado, reprodução por hormogônios e hormocitos, com ramificações verdadeiras;

Chroococcales: talo unicelular ou pseudofilamentoso, reprodução por fissão binária em 1 ou mais planos e/ou fissão múltipla;

Oscillatoriales: talo filamentoso homocitado, reprodução por hormogônios e hormocitos.

Aos poucos, estudos de âmbito botânico e bacteriológico estão convergindo; a classificação botânica está usando dados genéticos em adição aos tradicionais dados morfológicos, citológicos, ecológicos e bioquímicos (HOFFMANN et al., 2005; KOMÁREK \& ANAGNOSTIDIS, 2005), enquanto a classificação bacteriológica utiliza a nomenclatura botânica, em que as subseções nas quais o grupo está dividido equivalem às ordens na classificação botânica. Todavia, a nomenclatura difere nos dois sistemas de classificação, apesar de algumas propostas de unificação (OREN, 2004; HOFFMANN et al., 2005). 
Nos últimos anos, com a introdução de métodos modernos e a consequente mudança no entendimento desses organismos, as pesquisas com cianobactérias cresceram e influenciaram sua taxonomia. Com isso, os critérios utilizados na classificação do grupo precisaram ser reavaliados.

Em 2005, Hoffmann et al. readequaram o sistema de classificação anterior com base em dados morfológicos, ultraestruturais e genéticos, principalmente de 16S rRNA. Nesse sistema, as proclorófitas foram incluídas em Cyanobacteria, algumas formas cocoides e filamentosas são interpretadas como polifiléticas e as espécies heterocitadas formam um clado único e estão organizadas em uma subclasse. A divisão em subclasses foi baseada na disposição dos tilacoides na célula e na presença de células diferenciadas. As cocoides e as formas filamentosas foram separadas em nível de ordem.

Gloeobacterophycidae: talo unicelular, sem tilacoides;

Synechococcophycidae: talo unicelular, pseudofilamentoso ou filamentoso, tilacoides com arranjo parietal;

Oscillatoriophycidae: talo unicelular, pseudofilamentoso ou filamentoso, tilacoides com arranjo radial;

Nostocophycidae: talo filamentoso, tilacoides com arranjo irregular.

Nota-se assim, que a construção de classificações baseando-se em diferentes tipos de informações gera diferentes classificações. Sabe-se hoje, que dados moleculares são critérios básicos na classificação taxonômica, no entanto não se pode pensar que o sistema filogenético correto vai ser construído sem a combinação cuidadosa do maior número de dados possíveis.

\section{DIVERSIDADE DE CIANOBACTÉRIAS EM LAGOAS E BANHADOS}

No Brasil, em geral, usa-se o termo lagoa para referir-se a todos os corpos d'água costeiros e mesmo interiores, independentemente de sua origem. No entanto, segundo Esteves (1998), lagos e lagoas possuem conceitos diferentes: lagos são corpos d'água interiores, de água doce, salobra ou salgada, sem comunicação direta com o mar e suas águas têm em geral baixo teor de íons quando comparadas com as águas oceânicas, enquanto lagoas diferem de lagos por apresentarem profundidades menores, em que a radiação pode alcançar o sedimento.

Corpos d'água conhecidos como banhados são elementos paisagísticos inundados que geralmente se desenvolvem próximos às margens de rios e lagos (GORHAM, 1996). Quando originados a partir de lagos, estes podem, eventualmente, ser convertidos inteiramente em banhados pela deposição de silte e turfa. Os maiores banhados formam-se em terrenos planos nos quais os 
solos úmidos são invadidos por vegetações formadores de turfeiras. Tanto lagos como banhados não são elementos permanentes, pois são fenômenos de curta duração em escala geológica.

Didaticamente, as lagoas podem ser divididas em compartimentos (ESTEVES, 1998), no entanto, estes não podem ser considerados como porções isoladas, pois estão em constante interação através de trocas de matéria e energia: região litorânea e região limnética ou pelágica.

Região Litorânea: corresponde ao compartimento da lagoa que está em contato direto com o ecossistema terrestre adjacente, sendo assim, influenciado diretamente por ele; trata-se de uma região com grande número de nichos ecológicos e cadeias alimentares; apresenta todos os níveis tróficos de um ecossistema, podendo ser considerado um compartimento autônomo. Nesta região as cianobactéiras podem ser encontradas constituindo as comunidades bentônicas, perifíticas, metafíticas e planctônicas.

Região Limnética ou Pelágica: corresponde à região que compreende a coluna d'água sobre o substrato lacustre. O plâncton e o nécton são suas comunidades características.

Tanto em lagoas e banhados, as cianobactérias podem ser encontradas constituindo as comunidades:

- Bentônica: conjunto de organismos que, em parte ou em todo seu ciclo de vida, permanecem aderidos ao sedimento do fundo de ambientes aquáticos;

- Perifítica: conjunto de organismos aderidos a substratos inorgânicos ou orgânicos vivos ou mortos. Podem ser epipélicos, quando aderidos a sedimentos orgânicos, epilíticos, sobre rochas, epifíticos, na superfície de algas ou macrófitas, epizoicos, sobre animais, e episâmicos, sobre grãos-de-areia.

- Planctônica: conjunto de organismos suspensos na coluna d'água e não dispõem de movimentos próprios capazes de se opor à força das correntes de água.

- Metafítica: conjunto de organismos não estritamente aderidos a um substrato nem verdadeiramente suspenso. Normalmente origina-se de populações de microrganismos livres que se agregam entre macrófitas ou detritos da região litorânea, como resultado do movimento da água induzido pelo vento.

As cianobactérias são constituintes importantes das comunidades planctônicas. Uma característica marcante em quase todas as espécies de cianobactérias encontradas nessa comunidade é a presença de aerótopos. Outra adaptação que pode ser observada nas cianobactérias planctônicas é a presença de envelope mucilaginoso. Muitas espécies, quando em condições favoráveis, formam florações, principalmente em ambientes eutrofizados.

Dentre as cianobactérias planctônicas, destacam-se os gêneros: Anabaenopsis, Aphanizomenon, Aphanothece, Cyanodictyon, Cylindrospermopsis, Dolichospermum, 
Limnothrix, Microcystis, Planktolyngbya, Planktothrix, Prochlorothix, Pseudanabaena, Radiocystis, Romeria, Snowella, Synechococcus, Synechocystis, Trichodesmium.

A comunidade metafítica também é bastante rica quanto à diversidade de cianobactérias. As espécies encontradas nesta comunidade podem ter origem das comunidades planctônicas, bentônicas e perifíticas.

Dentre as cianobactérias metafíticas, destacam-se os gêneros: Aphanocapsa, Aphanothece, Chroococcus, Geitlerinema, Gloeocapsa, Gloeothece, Gloeotrichia, Hapalosiphon, Leptolyngbya, Merismopedia, Microcrocis, Nostoc, Oscillatoria, Phormidium, Romeria, Schizothrix, Spirulina, Stigonema.

Lagoas e banhados costeiros apresentam condições físicas e químicas especiais, constituindo hábitats de interesse científico, pois podem abrigar espécies não encontradas em outras condições ambientais e fornecer informações importantes do ponto de vista taxonômico e evolutivo. O estudo realizado por Werner (2002) é o mais amplo abordando lagoas e lagunas costeiras do Rio Grande do Sul, tendo resultado no registro de 77 táxons específicos, incluindo a descrição de uma nova espécie para a ciência (Aphanothece zulanirae Werner et Sant'Anna), a primeira citação para o Brasil de Microcrocis pulchella (Buell) Geitler, a primeira citação para o estado de outras 11 espécies e outros três táxons são provavelmente novidades taxonômicas ainda a serem confirmadas. Estes resultados demonstram o desconhecimento da flora existente nestes ambientes e ilustram a alta e importante diversidade encontrada nestes ambientes costeiros.

\section{PLANÍCIE COSTEIRA DO RIO GRANDE DO SUL}

A planície costeira do Rio Grande do Sul é constituída em parte pela Bacia de Pelotas e está apoiada sobre o embasamento composto pelo complexo cristalino pré-cambriano e pelas sequências sedimentares e vulcânicas, paleozoicas e mesozoicas da Bacia do Paraná (VILLWOCK \& TOMAZELLI, 2007). A planície é alongada na direção sudoeste-nordeste (SO-NE) e está localizada entre os paralelos $29^{\circ} 12^{\prime}$ e $33^{\circ} 48^{\prime}$ de latitude sul e os meridianos $49^{\circ} 40^{\prime}$ e $53^{\circ} 30^{\prime}$. Compreende uma área de aproximadamente $33.000 \mathrm{~km}^{2}$, em grande parte ocupada por um grande número de corpos d'água, alguns com grandes dimensões, tais como a laguna dos Patos com $10.000 \mathrm{~km}^{2}$, a lagoa Mirim com 3,770 $\mathrm{km}^{2} \mathrm{e}$ a lagoa Mangueira com 802 $\mathrm{km}^{2}$; apresenta $600 \mathrm{~km}$ de extensão e largura em torno de 60 a $70 \mathrm{~km}$ na porção centro-sul e de 15 a 20 km na porção norte (TOMAZELLI et al., 2000; WESCHENFELDER et al., 2005). 
A planície costeira consiste num conjunto de faces agrupadas dentro de um sistema de leques aluviais e do sistema tipo laguna-barreira (VILLWOCK et al., 1986).

A planície costeira é uma região de clima subtropical úmido; a precipitação pluviométrica anual fica entre 1.000 e $1.500 \mathrm{~mm}$ e a temperatura média anual oscila entre 16 e $20^{\circ} \mathrm{C}$. A média do mês mais quente fica entre 22 e $26^{\circ} \mathrm{C}$ e a média do mês mais frio entre 10 e $15^{\circ} \mathrm{C}$ (NIMER, 1977; VILLWOCK \& TOMAZELLI, 2007). Os ventos são característicos da região, possuindo direções predominantes relativamente constantes.

Em toda a planície costeira existe uma forte dominância de ecossistemas de áreas úmidas, como estuários e deltas; praias marinhas, rios e arroios; savanas; palmares; campos e florestas de inundação estacional, temporária ou permanente; lagoas e lagunas de água doce ou salobra; e banhados, sendo, estes últimos, de especial importância (BURGER \& RAMOS, 2007).

A planície costeira pertence a duas províncias biogeográficas distintas: a província Atlântica, com vegetação florestal predominantemente tropical e que se estende pelo litoral norte do estado e a província Pampeana, dominada por uma vegetação campestre de caráter subtropical e que se estende pelo litoral centro-sul (WAECHTER, 1985). Além dos elementos provenientes das províncias, estão presentes também componentes patagônicos, andinos, chaquenhos e holárticos (BECKER et al., 2007) e, devido a esta característica, a biota da planície costeira apresenta baixo número de endemismos quando comparada a outras regiões.

\section{OBJETIVOS}

\section{Geral}

O levantamento e estudo taxonômico das cianobactérias ocorrentes em ambientes aquáticos na área da lagoa do Casamento e ecossistemas associados, assim como em áreas adjacentes à lagoa do Cerro.

\section{Específicos}

- Estudo taxonômico das cianobactérias encontradas nos ambientes inventariados;

- Análise das variações morfológicas e métricas das populações ocorrentes nos diferentes ambientes analisados;

- Ampliar o conhecimento da diversidade e distribuição das cianobactérias no estado do Rio Grande do Sul e, consequentemente, no Brasil. 


\section{MATERIAL E MÉTODOS}

\section{Área de Estudo}

A região estudada engloba quatro áreas indicadas como prioritárias para a zona costeira meridional do Brasil no Workshop "Avaliação de Ações Prioritárias para as Zonas Costeira e Marinha", todas elas situadas ao sul de Porto Alegre. Como três destas áreas são geograficamente contíguas, foram estudadas em conjunto e receberam a denominação de “Área da lagoa do Casamento", sendo composta pelas regiões da lagoa do Casamento, da lagoa dos Gateados e do banhado da fazenda Cavalhada, classificadas como insuficientemente conhecida, de extrema importância biológica e de grande importância biológica, respectivamente. A área denominada "região dos butiazais de Tapes" inclui apenas uma área prioritária classificada como de extrema importância biológica (BRASIL, 2002). A área dos butiazais de Tapes recebeu essa denominação por ser uma região dominada por butiá, uma palmeira da espécie Butia capitata.

As duas regiões de estudo estão localizadas entre os paralelos $30^{\circ} 40^{\prime}$ e $30^{\circ} 10^{\prime}$ de latitude sul e os meridianos $50^{\circ} 30^{\prime}$ e $51^{\circ} 30^{\prime}$ de longitude oeste (Figura 1). A área apresenta complexos mosaicos de dunas, banhados, campos e matas. Apesar das duas regiões se encontrarem geograficamente próximas, as áreas da lagoa do Casamento e dos butiazais de Tapes apresentam diferenças quanto ao relevo, composição do ambiente e uso da terra, configurando paisagens distintas (BECKER et al., 2007).

\section{Área da lagoa do Casamento}

A região está situada na península de Mostardas, limite leste da laguna dos Patos, possui aproximadamente 235.600 ha e abrange partes dos municípios de Palmares do Sul, Capivari do Sul, Mostardas e Viamão. Segundo Ramos et al. (2007), a região da lagoa do Casamento e ecossistemas associados é composta por um mosaico de ambientes, o que permite dividi-la em 11 unidades de paisagem, de acordo com as áreas urbanas, a vegetação, o relevo, os corpos d água e o uso da terra.

A área é caracterizada por grandes planícies, lagoas, banhados, florestas, campos e áreas agrícolas. As áreas urbanas são representadas por manchas das cidades de Capivari do 
Sul e Palmares do Sul. Além das manchas urbanas, a região é composta por campos de dunas, campos arenosos, campos de pastagem e áreas de silvicultura.

Os corpos d'água são representados pelos rios Capivari e Palmares e pela sanga do Cerrito. As lagoas presentes são as lagoas do Capivari, da Anastácia, dos Gateados e do Casamento, além do sangradouro, que exerce função importante no escoamento da lagoa dos Gateados para a lagoa do Casamento.

A maior parte da região é de planície, predominando campos de dunas e campos arenosos, às vezes com suaves depressões. Também são observadas coxilhas suaves e arredondadas, constituídas por mosaicos de campos, pequenos açudes, áreas de pecuária, matas ciliares e sede de fazendas.

A região também apresenta banhados com vegetação herbácea, arbustiva, arbórea, porções com florestas de restinga, florestas paludosas, dunas vegetadas, bancos de areia, macrófitas aquáticas, além de ilhas preservadas, representando assim, uma área de grande biodiversidade, apesar de bastante fragmentada.

\section{Área dos butiazais de Tapes}

Localiza-se entre os municípios de Barra do Ribeiro e Tapes e abrange uma área de 83.174 ha. Caracteriza-se por duas áreas de planícies, uma fluvial e outra lagunar, cortadas longitudinalmente pela Coxilha das Lombas, com morros graníticos ao noroeste e a laguna dos Patos a leste. Segundo Ramos et al. (2007) a região pode ser dividida em 12 unidades de paisagens.

Grande parte da região apresenta áreas planas com variedade de paisagens, como cordões rochosos, cristas praiais, lagoas, mosaico de banhados naturais, fragmentados por áreas de arrozais e campos úmidos, pequenas represas e canais de drenagem.

A região também apresenta coxilhas e morros graníticos com uma cobertura diversa. Nessas localidades encontramos florestas, áreas de campos com butiazais e depressões úmidas. Em muitas áreas a cobertura natural foi substituída por extensas áreas de silvicultura, com plantações de eucaliptos e pinheiros. Porções dessas regiões são constituídas por campos com agropecuária e florestas de galeria, às vezes com um relevo bastante acidentado. Uma pequena parte de floresta nativa é encontrada em morros graníticos.

As lagoas são representadas pelas lagoas das Capivaras, do Charutão, Redonda, do Cerro, Comprida e Suja e outros corpos d'água entre dunas e banhados. 


\section{Amostragem e métodos de coletas}

O presente estudo foi baseado na análise de 90 amostras obtidas em diferentes sistemas aquáticos da planície costeira do Rio Grande do Sul. As coletas ocorreram por meio do programa de trabalho "Avaliação da biodiversidade na região da lagoa do Casamento e dos butiazais de Tapes, Planície Costeira do Rio Grande do Sul”, desenvolvido por pesquisadores do Museu de Ciências Naturais da Fundação Zoobotânica do Rio Grande do Sul.

As coletas foram realizadas nos meses de maio e junho (período de águas altas) e em outubro, novembro e dezembro de 2003 (período de águas baixas), sendo amostrados 16 ambientes aquáticos, dos quais 15 foram incluídos neste estudo.

As amostras estudadas foram obtidas em 28 pontos fixos de coleta (Tabela 1), distribuídos pelas sete lagoas, cinco banhados, um sangradouro, um arroio e um açude, sendo 18 pontos na área da lagoa do Casamento e 10 na dos butiazais de Tapes.

Tabela 1: Pontos e ambientes amostrados nas áreas da lagoa do Casamento (LC) e dos butiazais de Tapes (BT) com suas respectivas localizações geográficas.

\begin{tabular}{cclll}
\hline Ponto & Região & \multicolumn{1}{c}{ Ambiente } & Localização(UTM) & \multicolumn{1}{c}{ Cidade } \\
\hline 1 & LC & banhado entre lagoas do Casamento e do & $541830-6654326$ & Capivari do Sul \\
2 & & Capivari & & \\
3 & LC & lagoa do Capivari & $542910-6655896$ & Capivari do Sul \\
4 & LC & lagoa do Casamento - margem & $541607-6654229$ & Palmares do Sul \\
5 & LC & lagoa do Casamento - margem & $541719-6654246$ & Palmares do Sul \\
6 & LC & lagoa do Casamento - zona pelágica & $542604-6650282$ & Palmares do Sul \\
7 & LC & lagoa dos Gateados - margem sul & $532524-662175$ & Mostardas \\
8 & LC & lagoa dos Gateados - margem sul & $534469-6622054$ & Mostardas \\
9 & LC & lagoa dos Gateados - margem sul & $534328-6622078$ & Mostardas \\
10 & LC & lagoa dos Gateados - zona pelágica & $532703-6622801$ & Mostardas \\
11 & LC & lagoa dos Gateados - margem do canal & $533050-6620403$ & Mostardas \\
12 & bC & sanhado dos Gateados - margem & $531876-6628854$ & Palmares do Sul \\
13 & LC & lagoa dos Gateados - margem norte & $532237-6625117$ & Mostardas \\
14 & LC & lagoa dos Gateados - margem noroeste & $532053-6624520$ & Mostardas \\
15 & LC & lagoa dos Gateados - margem & $532285-6624514$ & Mostardas \\
16 & LC & lagoa dos Gateados - zona pelágica & $533263-6624909$ & Mostardas \\
17 & LC & lagoa dos Gateados - zona pelágica & $534199-6622969$ & Mostardas \\
18 & LC & banhado - Rincão do Anastácio & $530749-6639690$ & Palmares do Sul \\
19 & BT & lagoa das Capivaras - margem & $473595-6629067$ & Tapes \\
20 & BT & lagoa das Capivaras - zona pelágica & $473595-6629067$ & Tapes \\
21 & BT & banhado com Sphagnum & $473385-6628689$ & Tapes \\
22 & BT & lagoinha entre dunas & $473435-6628655$ & Tapes \\
23 & BT & banhado entre dunas & $473603-6628803$ & Tapes \\
24 & BT & lagoa do Charutão - margem & $465956-6623899$ & Tapes \\
25 & BT & lagoa do Charutão - zona pelágica & $465745-6623421$ & Tapes \\
26 & BT & açude da Fazenda São Miguel & $464203-6623642$ & Tapes \\
27 & BT & lagoa Redonda & $465503-6622735$ & Tapes \\
28 & BT & arroio Araçá & $461948-6626264$ & Tapes \\
\hline & & & &
\end{tabular}


Foram obtidas, quando possível, dados físicos e químicos dos pontos amostrados, como salinidade, $\mathrm{pH}$, condutividade da água, bem como profundidade total e transparência da água, estimada através da leitura do desaparecimento visual do disco de Secchi.

Todas as amostras coletadas foram acondicionadas em frascos de vidro incolores, etiquetados com indicação do número de registro do Herbário Prof. Alarich R. H. Schultz (HAS) do Museu de Ciências Naturais da Fundação Zoobotânica do Rio Grande do Sul, em Porto Alegre, onde foram depositados. Do total de amostras, 90 foram selecionadas para esse estudo (Tabela 2).

Para a coleta de cianobactérias planctônicas, foram utilizados métodos de filtragem da água e concentração com rede de plâncton de $25 \mu \mathrm{m}$ de abertura de malha (passada no mínimo 30 vezes próximo à superfície da água) e pela coleta direta na superfície da água.

As cianobactérias perifíticas foram coletadas por meio do recolhimento de materiais frouxamente aderidos ao substrato (metafíton) através da técnica de espremido de partes submersas de macrófitas aquáticas e de algas macroscópicas.

Para a preservação do material coletado, foram utilizadas soluções de Transeau ou de formaldeído, nas proporções 1:1 e 4:1, respectivamente, com a água da amostra.

\section{Análise e identificação}

Para estudos de identificação foram preparadas, no mínimo, cinco lâminas de cada amostra, a fim de se obter a maior representatividade possível em relação ao número de espécies e para estudo da variabilidade morfológica.

A análise das amostras foi efetuada utilizando-se microscópios fotônicos Zeiss Axioplan, Leica DMLB (Fundação Zoobotânica do Rio Grande do Sul) e Olympus BH2, com câmara clara (Laboratório de Biologia, Ecologia e Taxonomia de Algas, BETA, Departamento de Zoologia e Botânica, UNESP, campus de São José do Rio Preto).

Quando o material estudado fora encontrado emaranhado com algas, detritos ou partículas, foi necessária a separação prévia, sob lupa, em placas de Petri com água destilada e auxílio de pinças e agulhas histológicas, para facilitar a visualização ao microscópio. Para uma visualização melhor da mucilagem, foi utilizado tinta nanquim.

Os caracteres analisados e que possibilitaram a identificação dos táxons apresentados neste trabalho foram os seguintes: 1) morfologia externa, 2) planos de divisão; 3) tipo e dimensões de colônias; 4) distribuição das células na colônia; 5) presença ou ausência, forma, dimensões e coloração da mucilagem; 6) forma e dimensões celulares; 7) presença ou 
ausência, disposição e número de grânulos; 8) presença ou ausência, disposição e número de aerótopos; 9) relação celular entre comprimento e largura; 10) estrutura do tricoma; 11) forma do ápice do tricoma; 12) diâmetro da espira, em tricomas espiralados; 13) distância entre as espiras, em tricomas espiralados; 14) forma, posição, número e dimensões dos heterócitos; 15) forma, posição, número e dimensões dos acinetos.

O sistema de classificação utilizado foi o de HOFFMANN et al. (2005) para níveis taxonômicos superiores a família e para níveis iguais ou inferiores a família os trabalhos de Anagnostidis \& Komárek (1990 - Stigonematales) e Komárek \& Anagnostidis (1989 Nostocales, 1998 - Chroococcales e 2005 - Oscillatoriales). A identificação específica dos espécimes foi baseada na literatura especializada para taxonomia de cianobactérias e, sempre que possível, foram comparadas com suas descrições originais.

Os táxons inventariados foram descritos e ilustrados por meio de fotomicrografias e/ou de desenhos feitos com auxílio de câmara-clara acoplada ao sistema óptico do microscópio.

Nas descrições das espécies foram utilizadas as abreviações diâm. (diâmetro), compr. (comprimento) e alt. (altura).

Tabela 2: Amostras estudadas, incluindo os dados de coleta. $\mathrm{F}=$ frasco, $\mathrm{R}=$ rede, $\mathrm{E}=$ espremido

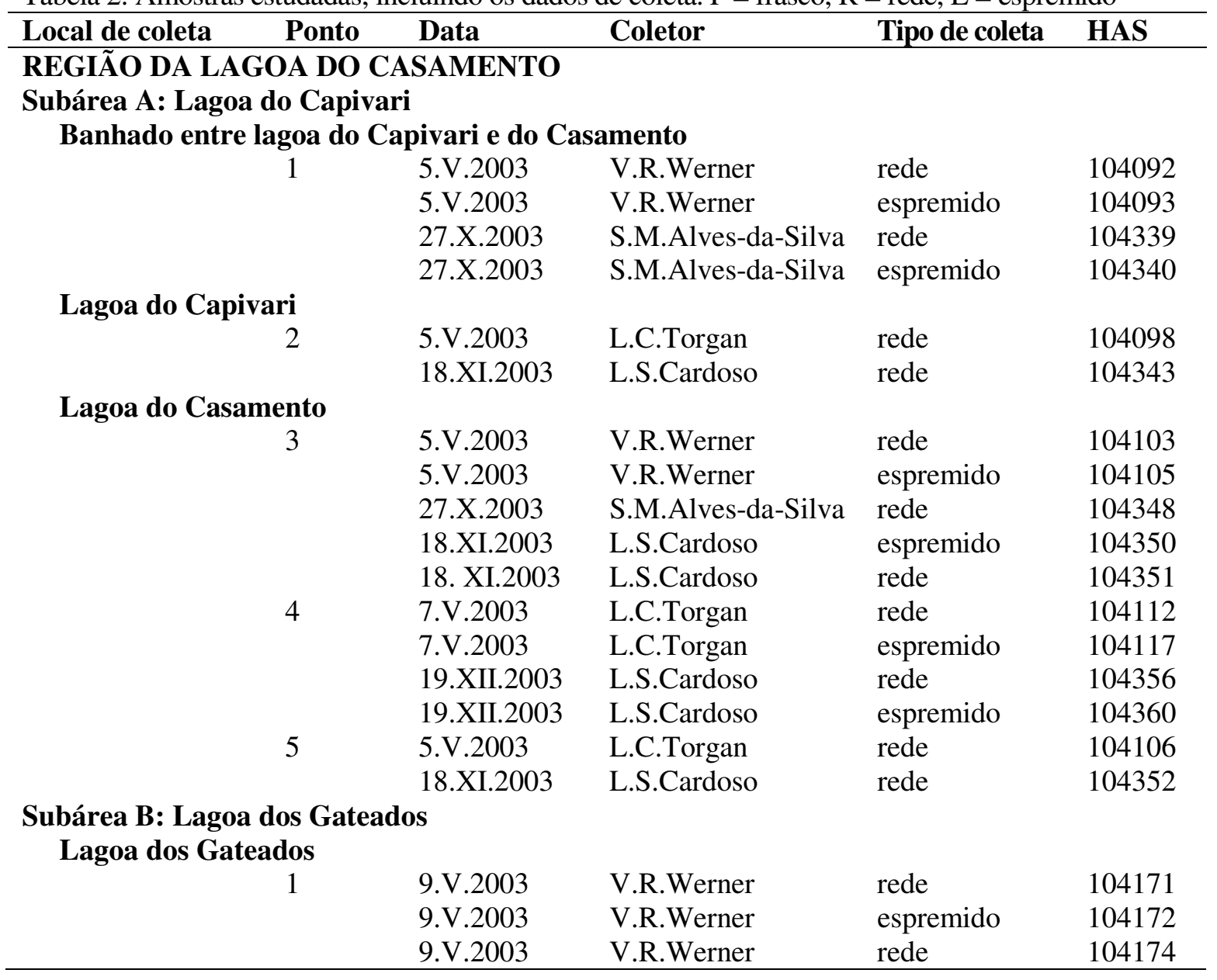


Tabela 2 (continuação).

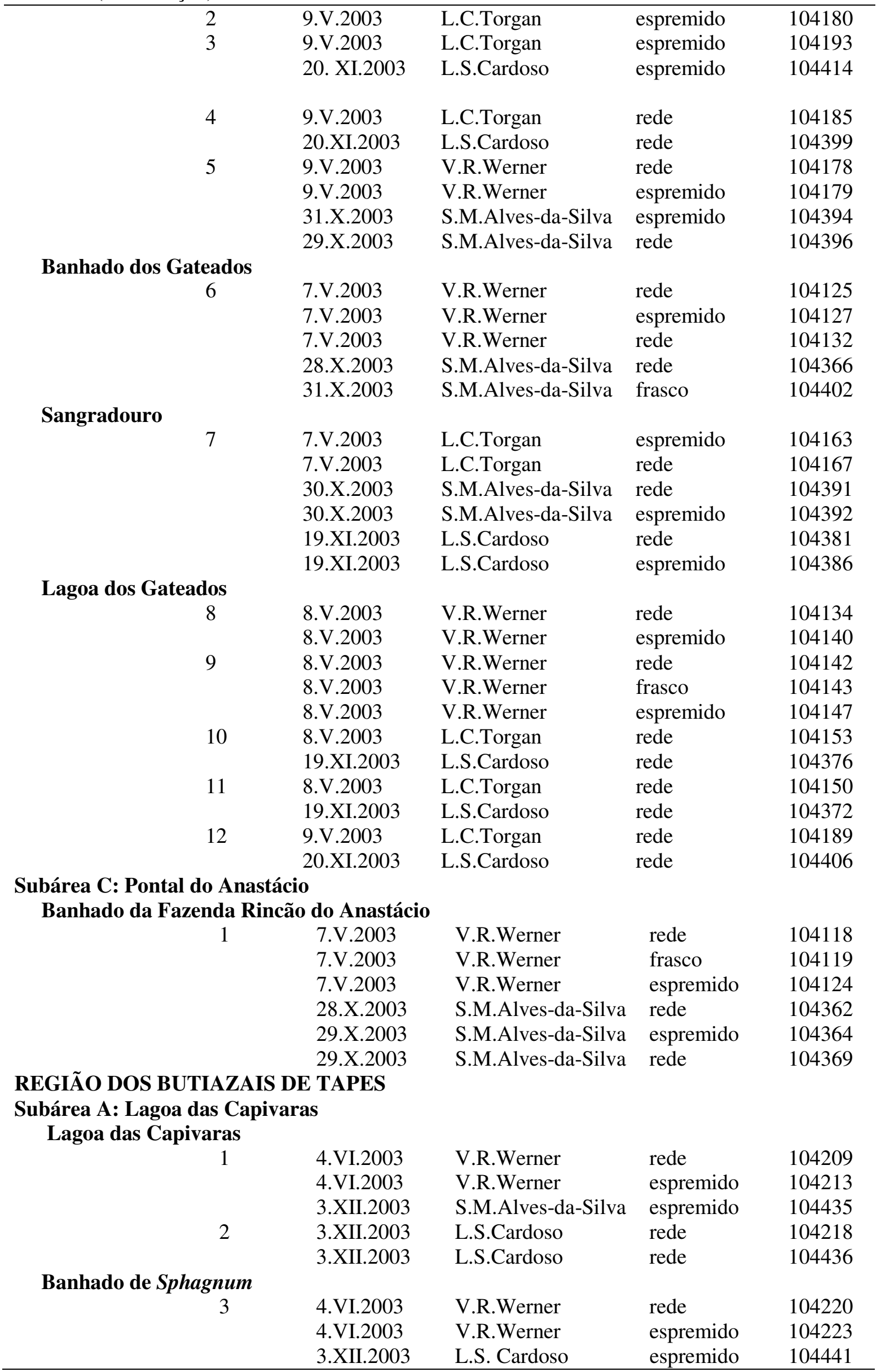


Tabela 2 (continuação).

\begin{tabular}{|c|c|c|c|c|}
\hline \multicolumn{5}{|l|}{ Lagoinha entre dunas } \\
\hline \multirow[t]{4}{*}{4} & 4.VI.2003 & V.R.Werner & rede & 104227 \\
\hline & 4.VI.2003 & V.R.Werner & espremido & 104230 \\
\hline & 3.XII.2003 & L.S.Cardoso & rede & 104442 \\
\hline & 3.XII.2003 & L.S.Cardoso & espremido & 104445 \\
\hline \multicolumn{5}{|l|}{ Banhado entre dunas } \\
\hline \multirow[t]{4}{*}{5} & 4.VI.2003 & V.R.Werner & rede & 104232 \\
\hline & 4.VI.2003 & V.R.Werner & espremido & 104234 \\
\hline & 3.XII.2003 & L.S.Cardoso & rede & 104446 \\
\hline & 3.XII.2003 & L.S.Cardoso & espremido & 104449 \\
\hline \multicolumn{5}{|c|}{$\begin{array}{l}\text { Subárea B: Banhado Redondo } \\
\text { Lagoa do Charutão }\end{array}$} \\
\hline \multirow[t]{2}{*}{1} & 3.VI.2003 & V.R.Werner & rede & 104195 \\
\hline & 2.XII.2003 & S.M.Alves-da-Silva & rede & 104416 \\
\hline \multirow[t]{4}{*}{2} & 3.VI.2003 & L.C.Torgan & rede & 104197 \\
\hline & 4.VI.2003 & L.C.Torgan & espremido & 104202 \\
\hline & 2.XII.2003 & L.S.Cardoso & rede & 104420 \\
\hline & 2.XII.2003 & L.S.Cardoso & espremido & 104425 \\
\hline \multicolumn{5}{|c|}{ Açude da Fazenda São Miguel } \\
\hline \multirow[t]{4}{*}{3} & 4.VI.2003 & V.R.Werner & rede & 104203 \\
\hline & 4.VI.2003 & V.R.Werner & espremido & 104207 \\
\hline & 2.XII.2003 & L.S.Cardoso & rede & 104427 \\
\hline & 2.XII.2003 & L.S.Cardoso & espremido & 104431 \\
\hline \multicolumn{5}{|l|}{ Lagoa Redonda } \\
\hline \multirow{5}{*}{ 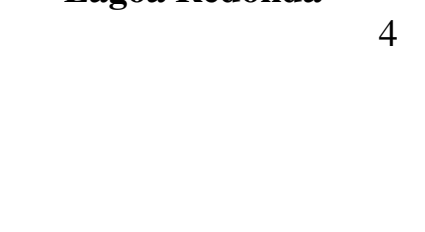 } & 4.VI.2003 & V.R.Werner & rede & 104235 \\
\hline & 5.VI.2003 & V.R.Werner & espremido & 104240 \\
\hline & 3.XII.2003 & L.S.Cardoso & rede & 104450 \\
\hline & 3.XII.2003 & L.S.Cardoso & rede & 104451 \\
\hline & 3.XII.2003 & L.S.Cardoso & espremido & 104455 \\
\hline \multicolumn{5}{|l|}{ Subárea C: Arroio Araçá } \\
\hline \multirow[t]{2}{*}{1} & 4.VI.2003 & V.R.Werner & rede & 104242 \\
\hline & 3.XII.2003 & L.S.Cardoso & frasco & 104457 \\
\hline
\end{tabular}

\section{Aspectos ecológicos}

Para análise ecológica, a diferença entre todos os habitats em termos da composição de espécies neles encontradas foi mensurada através da diversidade beta (MAGURRAN, 1988), utilizando-se o índice de Whittaker $(\beta \mathrm{W}=(\mathrm{S} / \alpha)-1$, onde $\mathrm{S}$ é o número total de espécies e $\alpha$ é a riqueza média) e utilizando-se o inverso do índice de Jaccard (1-Cj, onde $\mathrm{Cj}-\mathrm{j} /(\mathrm{a}+\mathrm{b}$ j), sendo j o número de espécies comuns entre as duas áreas, a o número de espécies da área $\mathrm{A}$ e b o número de espécies na área B) (WHITTAKER, 1972).

A similaridade entre os 15 ambientes foi comparada com base na composição (presença/ausência) das espécies. Para isso, foram feitas análises de dendrogramas utilizandose o coeficiente de Jaccard, para a matriz qualitativa (MAGURRAN, 1988). Estas avaliações foram conduzidas através do programa MVSP (KOVACH, 1998). 
A influência dos fatores abióticos ( $\mathrm{pH}$, condutividade, profundidade e Secchi) sobre a riqueza foi verificada através de análises de correlação de Spearman (ZAR, 1996). Os testes estatísticos foram realizados utilizando-se o programa BioEstat (AYRES et al., 2005).

\section{SINOPSE DOS TÁXONS IDENTIFICADOS}

Nos ecossistemas aquáticos estudados foram registrados 92 táxons específicos pertencentes às suclasses Synechococcophycidae (Synechococcales [25], Pseudanabaenales [9]), Oscillatoriophycidae (Chroococcales [12], Oscillatoriales [21]) e Nostocophycidae (Nostocales 25). Estes são apresentados na sinopse que se segue.

Cyanoprokaryota/ Cyanobacteria/Cyanophyceae

Synechococcophycidae

Synechococcales

Synechococcaceae

Aphanothecoideae

Aphanothece Nägeli

A. comasii Komárková-Legnerová

A. conglomerata Rich

A. minutissima (W. West) Komárková-Legnerová et Cronberg

A. smithii Komárková-Legnerová et Cronberg

A. stagnina (Sprengel) Braum

Cyanodictyon Pascher

C. reticulatum (Lemmermann) Geitler

C. tubiforme Cronberg

Epigloeosphaera Komárková-Legnerová

Epigloeosphaera sp.

Gloeothece Nägeli

G. incerta Skuja

Merismopediaceae

Merismopedioideae

Aphanocapsa Nägeli

A. conferta (W. et G. S. West) Komárková-Legnerová et Cronberg

A. delicatissima W. et G. S. West

A. elachista W. et. G. S. West

A. holsatica (Lemmermann) Cronberg et Komárek

A. incerta (Lemmermann) Cronberg et Komárek

A. cf. incerta (Lemmermann) Cronberg et Komárek

A. koordersii StrØm

Merismopedia Meyen

M. elegans A. Braum in Kützing

M. glauca (Ehrenberg) Kützing 
M. punctata Meyen

M. tenuissima Lemmermann

Microcrocis Richter

M. pulchella (Buell) Geitler

Gomphosphaerioideae

Coelomoron Buell

C. pusillum (Van Goor) Komárek

Coelosphaerium Nägeli

C. kuetzingianum Nägeli

Snowella Elenkin

S. lacustris (Chodat) Komárek et Hindák

Chamaesiphonaceae

Chamaesiphon Braum et Grunow in Rabenhorst

C. amethystinus (Rostafinski) Lemmermann

Psedanabaenales

Pseudanabaenaceae

Pseudanabaenoideae

Geitlerinema (Anagnostidis et Komárek) Anagnostidis

G. amphibium (Agardh ex Gomont) Anagnostidis

G. splendidum (Greville ex Gomont) Anagnostidis

Pseudanabaena Lauterborn

$P$. catenata Lauterborn

Leptolyngbyoideae

Leptolyngbya Anagnostidis et Komárek

L. cebennensis (Gomont) Umezaki et M. Watanabe

L. lagerheimii (Gomont) Anagnostidis et Komárek

L. perelegans (Lemmermann) Anagnostidis et Komárek

Planktolyngbya Anagnostidis et Komárek

$P$. contorta (Lemmermann) Anagnostidis et Komárek

P. limnetica (Lemmermann) Komárková-Legnerová et Cronberg

Spirulinoideae

Spirulina Turpin ex Gomont

S. laxissima f. major G. S. West

Oscillatoriophycidae

Chroococcales

Microcystaceae

Eucapsis Clements et Shantz

E. parallelepipedon (Schmidle) Komárek et Hindák

Microcystis Kützing ex Lemmermann

$M$. aeruginosa Kützing

$M$. protocystis Crow

M. smithii Komárek et Anagnostidis

$M$. wesenbergii (Komárek) Komárek

Chroococcaceae

Chroococcus Nägeli

C. dispersus (Keissler) Lemmermann

C. distans (G. M. Smith) Komárková-Legnerová et Cronberg

C. limneticus Lemmermann

C. microscopicus Komárková-Legnerová et Cronberg

C. minimus (Keissler) Lemmermann 


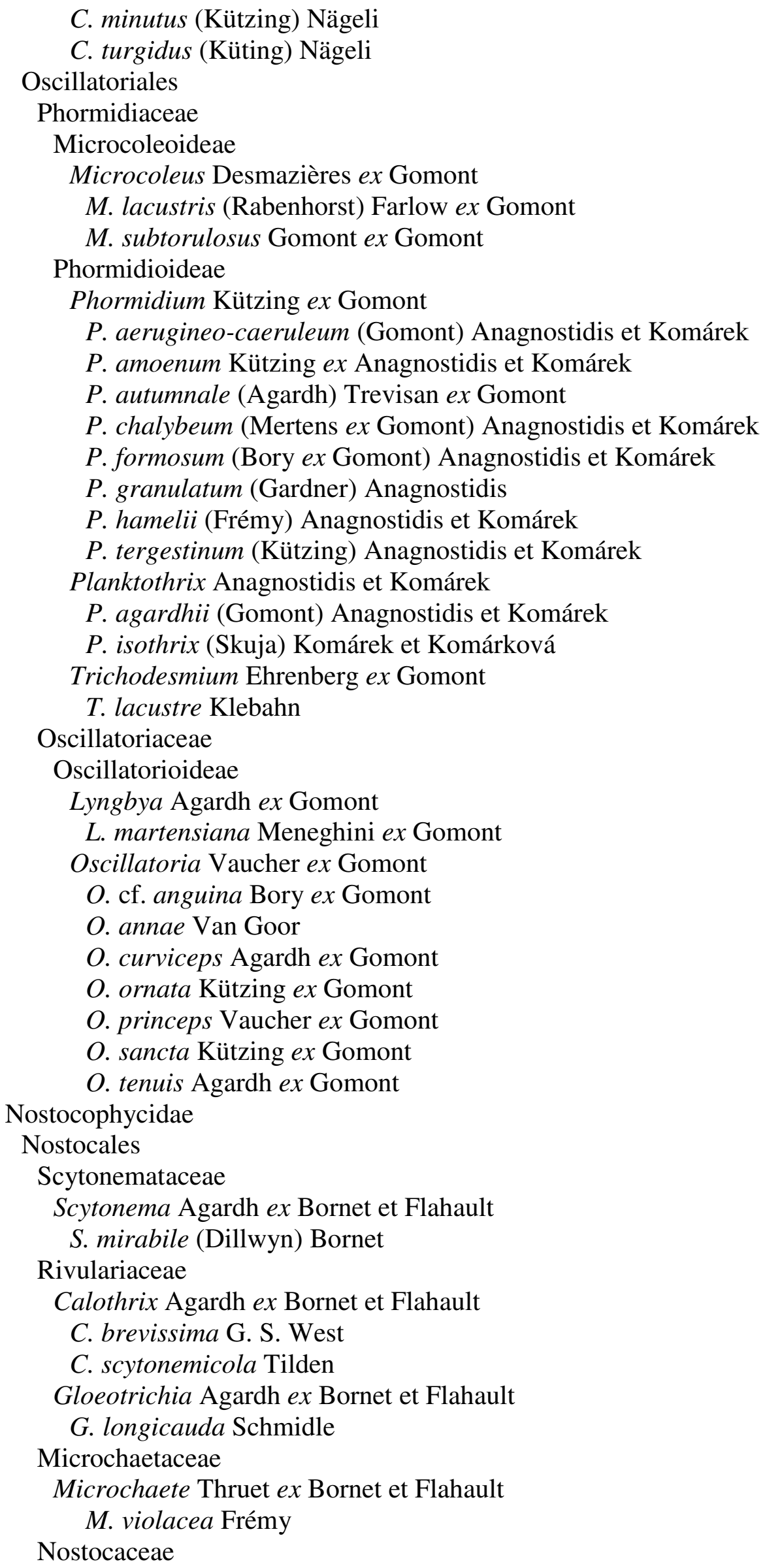


Anabaenoideae

Anabaena Bory ex Bornet et Flahault

A. inaequalis (Kützing) Bornet et Flahault

A. oscillarioides Bory ex Bornet et Flahault

A. sphaerica Bornet et Flahault

Cuspidothrix Rajaniemi et al.

C. issatschenkoi (Usacev) Rajaniemi et al.

Cylindrospermopsis (Wolosynska) Seenayya et Subba Raju

C. raciborskii (Wolosynska) Seenayya et Subba Raju

Cylindrospermum Kützing ex Bornet et Flahault

C. muscicola Kützing ex Bornet et Flahault

Dolichospermum Wacklin et al.

D. crassum ([Lemmermann] Komárková-Legnerová) Wacklin et al.

D. flos-aquae ([Lyngby] Brebisson) Wacklin et al.

D. planctonicum (Brunnthaler) Wacklin et al.

D. cf. solitarium (Klebahn) Wacklin et al.

D. spiroides (Klebahn) Wacklin et al.

D. viguieri (Denis et Frémy) Wacklin et al.

Hydrocoryne Schwabe ex Bornet et Flahault

Hydrocoryne sp.

Nostocoideae

Aulosira Kirchner ex Bornet et Flahault

A. laxa Kirchner ex Bornet et Flahault

Nostoc Vaucher ex Bornet et Flahault

$N$. cf. piscinalis Kützing ex Bornet et Flahault

$N$. spongiaeforme Agardh ex Bornet et Flahault

Mastigocladaceae

Hapalosiphon Nägeli in Kützing ex Bornet et Flahault

$H$. arboreus W. et G. S. West

H. hibernicus West et G. S. West

Hapalosiphon sp.

Stigonemataceae

Stigonema Agardh ex Bornet et Flahault

S. ocellatum (Dillwyn) Thuret ex Bornet et Flahault 


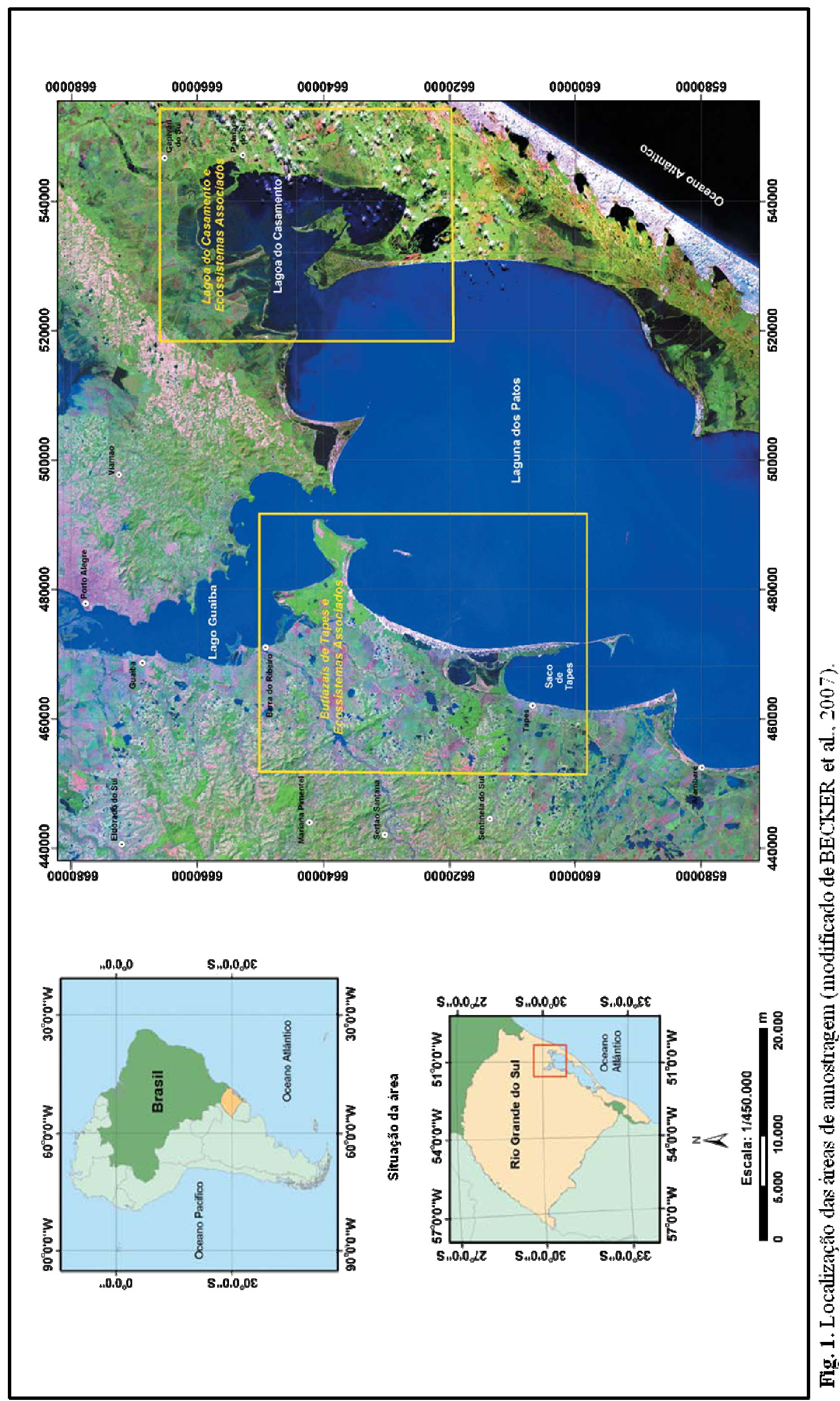




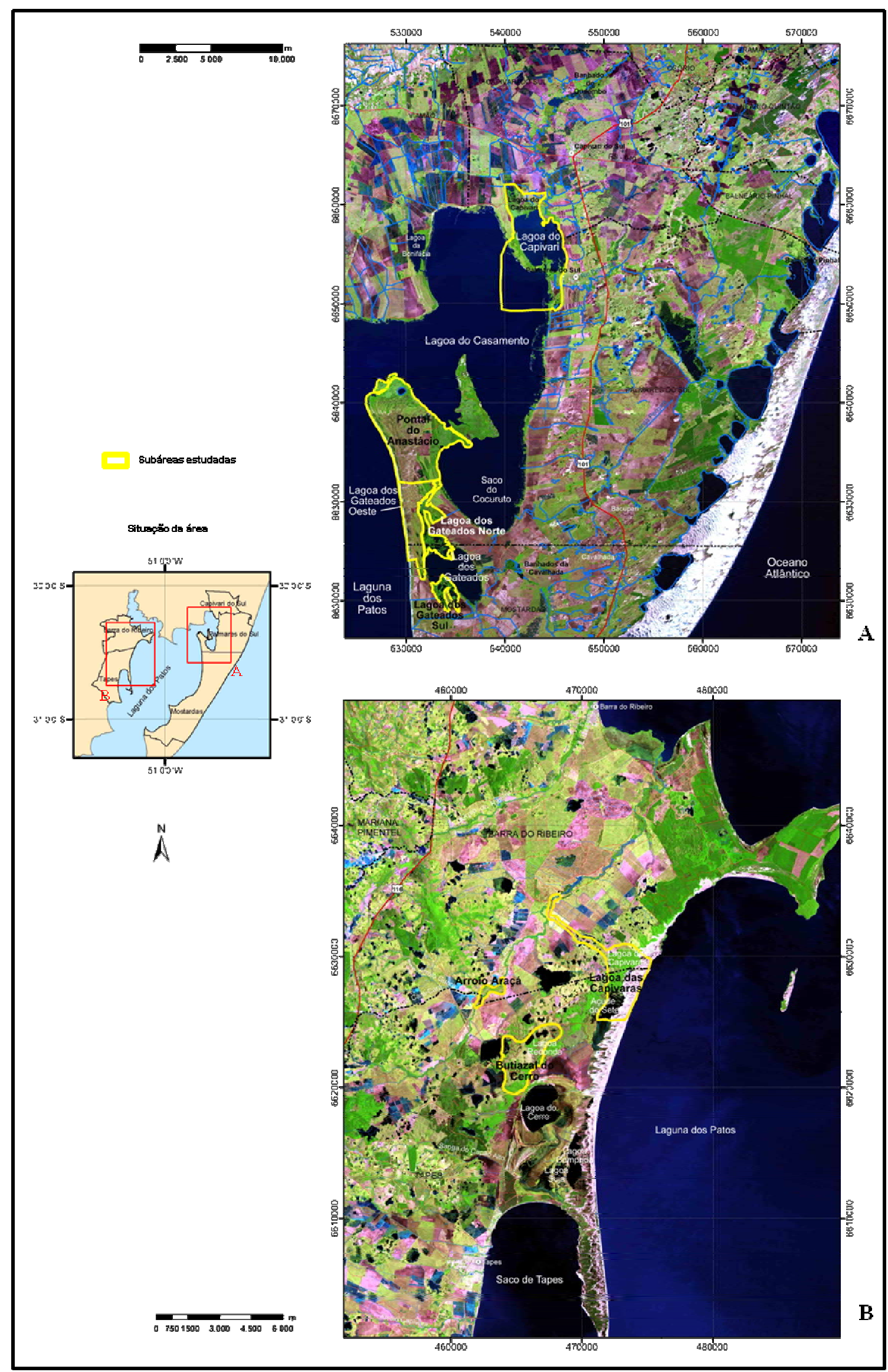

Fig. 2: A-B. A. Area da lagoa do Casamento e ecossistemas associados: B. Area dos Butiazais de Tapes e ecossistemas associados (modificado de BECKER et al. 2007). 


\section{RESULTADOS E DISCUSSÃO}

\section{ASPECTOS TAXONÔMICOS}

\subsection{SYNECHOCOCCOPHYCIDAE}

A subclasse Synechococcophycidae abrange as cianobactérias que apresentam tilacoides dispostos na região periférica das células. É composta por duas ordens que diferem entre si pela morfologia do talo: Synechococcales e Pseudanabaenales.

\section{SYNECHOCOCCALES}

A ordem Synechococcales é formada pelas cianobactérias unicelulares ou pseudofilamentosas. Nos sistemas de classificação propostos anteriormente, as cianobactérias que constituem a ordem Synechococcales, estavam incluídas em outras ordens e famílias. Segundo Rabenhorst (1865), as formas cocóides compunham a ordem Cytiphora, formada por uma única família, Chroococcaceae. Já no sistema de classificação de Geitler (1932), essas cianobactérias estavam classificadas na ordem Chroococcales, mais especificamente na família Chroococcaceae, composta pelas formas cocóides cujas células estão dispostas de maneira mais ou menos irregular no envelope mucilaginoso. No sistema de Komárek e Anagnostidis (1998), esses organismos integravam a ordem Chroococcales, dividida em 11 famílias de acordo com o tipo de divisão celular.

Segundo Hoffmann et al. (2005), as cianobactérias da ordem Synechococcales são distribuídas em quatro famílias: Acaryochloridaceae, Chamaesiphonaceae, Merismopediaceae e Synechococcaceae.

No presente estudo, três das quatro famílias são representadas pelo registro de 25 espécies: Synechococcaceae (9), Merismopediaceae (15) e Chamaesiphonaceae (1).

\section{CHAVE PARA IDENTIFICAÇÃO DAS FAMÍLIAS ENCONTRADAS}

1. Organismos sésseis Chamaesiphonaceae

1. Organismos não sésseis 
2. Divisão celular em único plano Synechococcaceae

2. Divisão celular em dois planos Merismopediaceae

\section{SYNECHOCOCCACEAE Komárek et Anagnostidis, 1995.}

A família Synechococcaceae destaca-se dentre as demais famílias de Synechococcophycidae por apresentar maior número de gêneros (27). Caracteriza-se pelas células que se dividem por fissão binária em um único plano de divisão nas sucessivas gerações. São células solitárias ou reunidas em colonias, com células irregularmente dispostas ou mais ou menos orientadas na colônia, às vezes formando pseudofilamentos. As células podem ser esféricas, alongadas, ovais, elípticas ou cilíndricas A mucilagem pode ser difluente ou firme, formando colônias esféricas, ovais, alongadas ou irregulares, às vezes clatradas e em muitos gêneros as células apresentam envelope mucilaginoso individual. Segundo Komárek \& Anagnostidis (1998), Synechococcaceae é definida por apresentar células alongadas e pela divisão celular ocorrer em apenas um plano em sucessivas gerações.

Synechococcaceae é dividida em duas subfamílias com base na capacidade de formar pseudofilamentos. Em Synechococcoideae, as células dispõem-se mais em uma direção formando pseudofilamentos e, em Aphanothecoideae, os organismos podem ser solitários ou coloniais cujas células apresentam disposição irregular na colônia, nunca formando pseudofilamentos (KOMÁREK \& ANAGNOSTIDIS, 1998).

No presente estudo foi registrada a ocorrência de nove espécies distribuídas em quatro gêneros, Aphanothece (5), Cyanodictyon (2), Epigloeosphaeria (1) e Gloeothece (1), pertencentes a uma única subfamília, Aphanothecoideae.

Subfamília Aphanothecoideae Komárek et Anagnostidis, 1995.

\section{CHAVE PARA IDENTIFICAÇÃO DOS GÊNEROS ENCONTRADOS}

1. Células dispostas acima da mucilagem colonial ...................................................... Epigloeosphaera

1. Células dispostas no interior da colônia .............................................................................2

2. Células com envelope mucilaginoso lamelado ............................................... Gloeothece

2. Células com ou sem envelope mucilaginoso, quando presente, nunca lamelado ......................3

3. Células dispostas irregularmente na colônia ...................................................Aphanothece

3. Células dispostas formando fileiras na colônia ............................................ Cyanodictyon 


\section{Aphanothece Nägeli, 1849.}

Espécie-tipo: Aphanothece microscopica Nägeli, Gatt. einz. Algen, p. 59. 1849.

O gênero Aphanothece caracteriza-se por apresentar colônias micro ou macroscópicas, com células que se dispõem densa ou esparsa e irregularmente no envelope mucilaginoso; células ovais a cilíndricas, retas ou levemente curvas, com ou sem aerótopos; reprodução por meio da fragmentação da colônia (KOMÁREK \& ANAGNOSTIDIS, 1998).

Apresenta ampla distribuição em todo o mundo e as espécies que o compõem ocupam os mais diversos hábitats. Segundo Komárek (1995), a taxonomia do gênero é confusa por diversas razões, tais como a morfologia bastante simples apresentada pelo grupo e a falta de precisão na descrição das espécies bem como a identificação errônea que ocorre com frequência; muitas das espécies já descritas são evidentemente sinônimos; espécies tropicais são normalmente identificadas com base em chaves de identificação de espécies européias ou norte-americanas; o pouco conhecimento sobre as espécies tropicais acarreta muitas identificações incorretas na literatura.

Komárek \& Anagnostidis (1998) dividem Aphanothece em três subgêneros. Anathece, constituído principalmente por espécies planctônicas, Aphanothece, formado por espécies coloniais edáficas, bentônicas, metafíticas ou aerofíticas, e Cyanogastrum, caracterizado por Komárek (1995) como um grupo composto por espécies tropicais que exibem colônias com mucilagem distinta e delimitada.

Segundo Hoffmann et al. (2005), as espécies de Aphanothece que possuem células pequenas fazem parte da família Synechococcaceae, e espécies com células grandes, como $A$. stagnina (Sprengel) Braun, foram reposicionados na família Cyanobacteriaceae (subclasse Oscillatoriophycidae). Cabe ressaltar que as espécies de Aphanothece que constituem a família Synechococcaceae, segundo Hoffmann et al. (2005), não apresentam suporte molecular nem estudos ultraestruturais.

No presente estudo foram documentadas cinco espécies de Aphanothece, três pertencentes ao Anathece (A. conglomerata, A. minutissima e A. smithii), uma ao Aphanothece (A. stagnina) e uma ao Cyanogastrum (A. comasii).

\section{Chave para identificação das espécies encontradas}

1. Células com aerótopos A. conglomerata

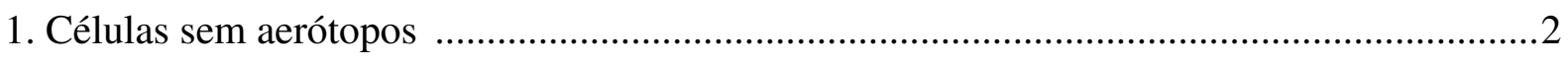

2. Células densamente aglomeradas no centro da colônia ...................................... A. comasii

2. Células dispostas esparsa e irregularmente na colônia 
3. Células maiores que 3,0 $\mu$ m diâm.

A. stagnina

3. Células com até 2,0 $\mu \mathrm{m}$ diâm.

.4

4. Células 0,6-1,0 $\mu \mathrm{m}$ diâm.

A. minutissima

4. Células 1,2-2,0 $\mu \mathrm{m}$ diâm.

A. smithii

Aphanothece comasii Komárek-Legnerová et Tavera, Algolog. Stud., v. 83, p. 408. 1996.

(Figs. 3A, 9A)

Colônias microscópicas esféricas ou ovais, 20,0-37,0 $\mu \mathrm{m}$ diâm., 30,0-49,0 $\mu \mathrm{m}$ compr.; células dispostas densa e irregularmente no centro da colônia; mucilagem homogênea, firme, incolor, margem evidente, espessa; células ovais com extremidades arredondadas, 1,8-3,0 $\mu \mathrm{m}$ diâm., 2,7-4,0 $\mu \mathrm{m}$ compr., 1,2 a 1,6 vez mais longas que largas; conteúdo celular verdeazulado, homogêneo ou granuloso; sem aerótopos.

Os espécimes observados e identificados como A. comasii possuem dimensões celulares que estão de acordo com as descritas para a espécie por Komárková-Legnerová \& Tavera (1996). A grande maioria da população observada era formada por colônias pequenas com poucas células dispostas densamente no centro da colônia, enquanto as colônias mais desenvolvidas apresentaram células mais frouxamente arranjadas. Embora Werner (2002) tenha observado representantes da espécie em água salobra no Rio Grande do Sul, a população estudada foi observada em ambiente de água doce, no plâncton, estando de acordo com o observado na descrição original da espécie.

Material examinado: HAS 104131, HAS 104132, HAS 104376.

Aphanothece conglomerata Rich, Trans. R. Soc. S. Afr., v. 20, p. 185. 1932.

(Fig. 3B)

Colônias microscópicas, alongadas ou irregulares, 28,5-78,0 $\mu$ m diâm., 80,0-213,0 $\mu \mathrm{m}$ compr.; células dispostas esparsa e irregularmente na colônia; mucilagem homogênea, firme, incolor, raramente lamelada, margem evidente ou raramente difluente; células ovais com extremidades arredondadas, 3,0-3,5 $\mu \mathrm{m}$ diâm., 4,0-5,8 $\mu \mathrm{m}$ compr., 1,3 a 1,7 vez mais longas que largas; conteúdo celular verde-azulado, homogêneo ou granuloso; com aerótopos.

As populações estudadas apresentaram dimensões dentro dos limites métricos descritos para a espécie.

Grande parte dos espécimes analisados era constituída por várias colônias agregadas e envoltas por uma mucilagem comum, às vezes lamelada. Essa característica aproxima morfologicamente a A. conglomerata de A. elebans (Brébisson) Elenkin, sendo estas, 
diferenciadas pela região de ocorrência e pelas dimensões celulares. A. elabens é típica de zonas temperadas e possui células menores [1-2(-3) x 2,8-6,5 $\mu \mathrm{m}]$, enquanto $A$. conglomerata é tida como presente no plâncton e metafíton de ambientes tropicais e subtropicais (KOMÁREK \& ANAGNOSTIDIS, 1998).

Embora A. conglomerata tenha sido descrita a partir de material de água salobra da África do Sul (ambiente subtropical), os espécimes analisados foram obtidos de amostra do plâncton de ecossistema de água doce. A espécie já havia sido registrada anteriormente para o Rio Grande do Sul por Torgan (1997), para ambientes de água doce e por Werner (2002) para ambientes de água doce e salobra.

Material examinado: HAS 104174.

Aphanothece minutissima (W. West) Komárková-Legnerová et Cronberg, Algol. Studies, v. 72, p. 24, 1994.

Basônimo: Microcystis minutissima W. West, Proc. R. Ir. Acad., v.31, p. 35, 1912.

(Fig. 3D)

Colônias microscópicas, esféricas, alongadas ou irregulares, 45,0-60,0 $\mu \mathrm{m}$ diâm., 54,096,6 $\mu \mathrm{m}$ compr.; células dispostas esparsa e irregularmente na colônia; mucilagem homogênea, firme, incolor, margem difluente; células ovais com extremidades arredondadas, 0,6-1,0 $\mu \mathrm{m}$ diâm., 1,3-1,8 $\mu \mathrm{m}$ compr., 1,3-2,4 vezes mais longas que largas; conteúdo celular verde-azulado, homogêneo; sem aerótopos.

Os exemplares analisados apresentaram dimensões métricas dentro do intervalo referido para a espécie. Segundo Komárková-Legnerová \& Cronberg (1994), A. minutissima é muito semelhante a A. pulverulenta Bachman e a A. nebulosa Skuja, principalmente quanto ao aspecto da colônia, podendo pertencer ambas a A. minutissima. No entanto, Komárek \& Anagnostidis (1998) consideram apenas A. pulverulenta como sinônimo de A. minutissima, mantendo A. nebulosa como uma espécie distinta por apresentar dimensões celulares menores $[0,5-1(1,5) \times 0,3-0,4]$.

Os últimos autores comentam ainda que a A. minutissima ocorre em regiões temperadas e que a identificação de populações da espécie em lagos de regiões tropical deveria ser revisada. Considerando que os espécimes observados apresentaram características semelhantes aos referidos por Komárková-Legnerová \& Cronberg (1994) e que os mesmos ocorreram em região subtropical, foram identificados como A. minutissima.

Material examinado: HAS 104098, HAS 104202, HAS 104343, HAS 104352, HAS 104369. 
Aphanothece smithii Komárková-Legnerová et Cronberg, Algol. Studies, v.72, p. 25. 1994.

(Figs. 3C, 9B)

Colônias microscópicas, esféricas, ovais, alongadas ou irregulares, 52,5 - 108,6 $\mu \mathrm{m}$ diâm., 62,9-221,8 Hm compr.; células dispostas esparsa e irregularmente na colônia; mucilagem homogênea, incolor, margem difluente; células ovais com extremidades arredondadas, 1,2-2,0 $\mu \mathrm{m}$ diâm., 1,7-3,9 $\mu$ m compr., 1,3 a 2,9 vezes mais longas que largas; conteúdo celular verde-azulado, homogêneo; aerótopos raros e diminutos.

Parte dos espécimes encontrados apresentam variações métricas de diâmetro e comprimento celular maiores do que os limites máximos referidos pelas autoras $(1,0-1,5$ diâm. e 1,8-3,5 compr.), no entanto, as demais características estão de acordo com a diagnose da espécie. As dimensões e formatos das colônias são variados, dentre as quais, as colônias alongadas apresentam células dispostas em fileiras, lembrando Cyanodictyon tubiforme, característica também observada por Komárková-Legnerová \& Cronberg (1994). No presente estudo, a ocorrência do táxon foi registrada no plâncton e no metafíton.

No Brasil, a espécie já foi observada nos estados de Rio de Janeiro (AZEVEDO et al., 1999), São Paulo (TUCCI et al. 2006), Paraná (FONSECA, 2008) e Rio Grande do Sul (WERNER \& ROSA, 1992; TORGAN, 1997; WERNER, 2002).

Material examinado: HAS 104124, HAS 104195, HAS 104202, HAS 104230, HAS 104343, HAS 104351, HAS 104352, HAS 104420, HAS 104425, HAS 104442.

Aphanothece stagnina (Sprengel) Braun, In: Rabenhorst, Flora Eur. Algar. 157 \& 158, 1572. 1863.

Basônimo: Coccochloris stagnina Sprengel, Fl. Halens. v. 1, p. 14. 1807.

(Figs. 3E, 9C-D)

Colônias microscópicas, esféricas, alongadas ou irregulares, 35,0-125,0 $\mu \mathrm{m}$ diâm., 63,0-247,5 m compr.; células dispostas esparsa e irregularmente na colônia; mucilagem homogênea, firme, incolor, margem difluente ou raramente evidente; células ovais com extremidades arredondadas, às vezes com envelope mucilaginoso, 4,0-6,0 $\mu \mathrm{m}$ diâm., 6,0-9,0 $\mu \mathrm{m}$ compr., 1,3 a 1,8 vezes mais longas que largas; conteúdo celular verde-azulado, homogêneo; sem aerótopos.

A. stagnina é uma espécie tida como bentônica, formando talos macroscópicos e que crescem entre plantas submersas e rochas, podendo ser encontrada tardiamente no plâncton. Entretanto, existem registros da ocorrência da espécie formando colônias microscópicas (KOMÁRKOVÁ-LEGNEROVÁ \& CRONBERG， 1994; WERNER， 1988; 
FRANCESCHINI, 1992; WERNER, 2002; JOOSTEN, 2006) como os espécimes observados no presente trabalho.

Alguns espécimes exibiram células dispostas em pequenos em grupos, às vezes circundados por mucilagem fina. Segundo Komárek \& Anagnostidis (1998), a espécie ocorre em regiões temperadas e registros desta para regiões tropicais devem ser revisados. Dessa forma, os organismos analisados foram identificados como A. stagnina, considerando o aspecto geral das colônias, as características métricas, que estão de acordo com as referidas para a espécie em questão na bibliografia consultada, e o fato de que os espécimes analisados foram encontrados em lagoas rasas, sujeitas à ação dos ventos, que poderia causar a remoção dos organismos bentônicos para a superfície da água.

Estudos filogenéticos têm mostrado que algumas espécies necessitam ser retiradas dos gêneros nos quais foram descritas, pois, filogeneticamente, pertencem a grupos distinto (KOMÁREK \& KASTOVSKY, 2003; KOMÁREK, 2006). A. stagnina, consiste em uma dessas espécies, pois está classificada como pertencente à família Cyanobacteriaceae (subclasse Oscillatoriophycidae), segundo a classificação proposta por Hoffmann et al. (2005).

Material examinado: HAS 104124, HAS 104134, HAS 104147, HAS 104174, HAS 104203, HAS 104230. 


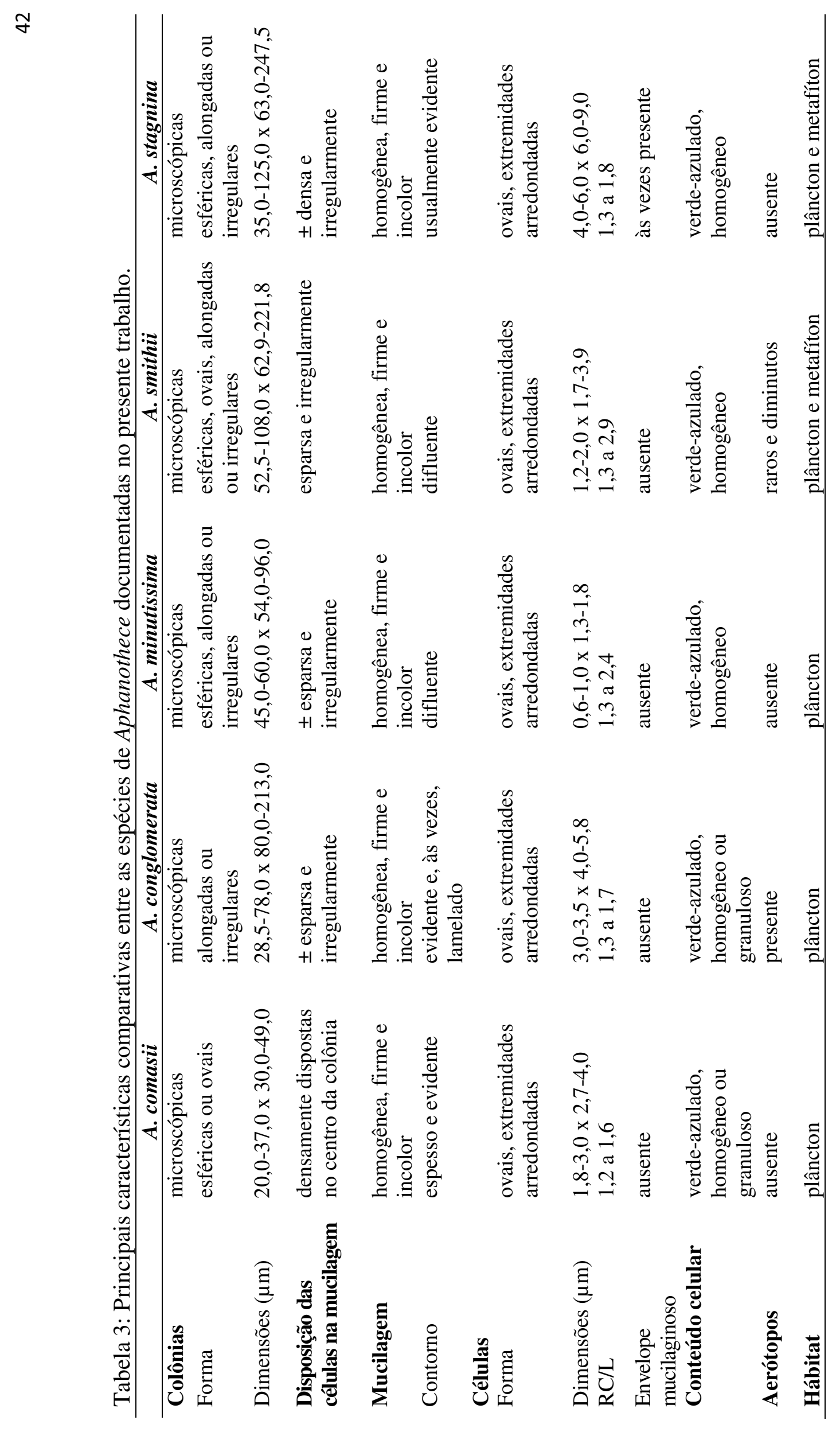




\section{Cyanodictyon Pascher, 1914.}

Espécie-tipo: Cyanodictyon endophyticum Pascher, Ber. Deutsch. Bot. Ges., v. 3, p. 351. 1914.

Cyanodictyon é um gênero descrito por Pascher, em 1914, a partir de material endofítico em mucilagem de uma espécie de Anabaena (JOOSTEN, 2006). Caracteriza-se por apresentar colônias microscópicas, inicialmente esféricas que formam redes irregulares, usualmente alongadas quando bem desenvolvidas; colônias compostas por células que se dispõem em fileiras uni ou multisseriadas, ramificadas ou não; mucilagem incolor e homogênea; células esféricas, ovais ou cilíndricas; reprodução através da desintegração da colônia (KOMÁREK \& ANAGNOSTIDIS, 1998).

Trata-se de um gênero com aproximadamente 10 espécies, principalmente planctônicas em corpos de água doce oligotróficos a mesotróficos, exceto por $C$. endophyticum, que é endofítica (GEITLER, 1932). Embora seja pouco documentado, provavelmente o gênero apresente uma ampla distribuição (KOMÁREK \& HAUER, 2009).

\section{Chave para identificação das espécies encontradas}

1. Células esféricas C. reticulatum

1. Células ovais ou cilíndricas C. tubiforme

Cyanodictyon reticulatum (Lemmermann) Geitler, In: Pascher, Süßw. Fl. Heft, v. 12, p. 103. 1925.

Basônimo: Polycystis (Clathrocystis) reticulate Lemmermann, Beitr. Kenntn. Planktonalg., Bot. Centralbl., v. 76, p. 153. 1898.

(Figs. 4A, 9E)

Colônias microscópicas arredondadas, alongadas ou irregulares, 12,0-33,0 $\mu \mathrm{m}$ diâm., 24,0-47,5 $\mu \mathrm{m}$ compr.; células dispostas em pseudofilamentos formando colônias reticuladas; mucilagem homogênea, firme, incolor, margem evidente; células esféricas, 0,9-1,4 $\mu \mathrm{m}$ diâm.; conteúdo celular verde-azulado, homogêneo; sem aerótopos.

As características morfológicas e métricas das populações analisadas estão de acordo com as estudadas por Geitler (1932) e por Komárková-Legnerová \& Cronberg (1994).

Segundo Geilter (1932), Cyanodictyon reticulatum constitui-se em uma espécie cosmopolita de água doce e planctônica. No sistema de lagoas amostradas, sua presença foi registrada tanto no plâncton quanto no metafíton.

Analisando os registros de sua ocorrência no Rio Grande do Sul, verificou-se que a espécie já havia sido documentada para a laguna dos Patos (TORGAN, 1997). 
Material examinado: HAS 104103, HAS 104106, HAS 104117, HAS 104131, HAS 104132, HAS 104163, HAS 104167, HAS 104343, HAS 104351, HAS 104352, HAS 104381.

Cyanodictyon tubiforme Cronberg, Arch. Hydrobiol., v. 80, p. 193. 1988.

(Figs. 4B, 9F-G)

Colônias microscópicas alongadas ou irregulares, às vezes clatradas, até 326,0 $\mu \mathrm{m}$ compr.; células dispostas em fileiras multisseriadas na colônia; mucilagem homogênea, firme, incolor, margem difluente; células ovais, cilíndricas ou hemisféricas após a divisão, 2,0-2,4 $\mu \mathrm{m}$ diâm., 2,0-2,9 $\mu \mathrm{m}$ compr., 1,0 a 1,4 vez mais longas que largas; conteúdo celular verdeazulado, homogêneo; sem aerótopos.

Não foi observada nos espécimes analisados a presença de colônias em estágios iniciais de desenvolvimento. Todos os representantes na espécie formavam colônias grandes, bem desenvolvidas, com células formando porções alongadas e multisseriadas. Algumas células não estavam orientadas nas fileiras, dando a falsa impressão das mesmas se dividirem em mais de um plano. As colônias mais desenvolvidas eram alongadas e ramificadas.

Embora a espécie seja documentada ocorrendo em zonas temperadas, os espécimes analisados foram identificados como $C$. tubiforme devido às características morfológicas, que estão de acordo com a descrição da espécie (CRONBERG, 1988), e ao fato de que o local onde ela ocorre estar em região subtropical. Seu registro no presente trabalho constitui a primeira citação para o Rio Grande do Sul.

Material examinado: HAS 104103, HAS 103106, HAS 104119, HAS 104167.

Tabela 4: Principais características comparativas entre as espécies de Cyanodictyon documentadas no presente trabalho.

\begin{tabular}{|c|c|c|}
\hline & C. reticulatum & C. tubiforme \\
\hline Colônias & microscópicas & microscópicas \\
\hline Forma & alongadas ou irregulares & alongadas ou irregulares \\
\hline Dimensões $(\mu \mathrm{m})$ & $12,0-33,0 \times 24,0-47,5$ & até 326 \\
\hline Mucilagem & homogênea, firme, incolor & homogênea, firme, incolor \\
\hline Contorno & evidente & difluente \\
\hline \multicolumn{3}{|l|}{ Células } \\
\hline Forma & esféricas & $\begin{array}{l}\text { ovais, cilídricas ou } \\
\text { hemisféricas após a divisão }\end{array}$ \\
\hline Dimensões $(\mu \mathrm{m})$ & $0,9-1,4$ & $2,0-2,4 \times 2,0-2,9$ \\
\hline $\mathrm{RC} / \mathrm{L}$ & - & 1,0 a 1,4 \\
\hline Conteúdo celular & verde-azulado, homogêneo & verde-azulado, homogêneo \\
\hline Aerótopos & ausente & ausente \\
\hline Hábitat & plâncton e metafíton & plâncton \\
\hline
\end{tabular}




\section{Epigloeosphaera Komárková-Legnerová, 1991.}

Espécie-tipo: Epigloeosphaera glebulenta (Zalessly) Komárková-Legnerová, Algolog. Stud., v. 62, p. 10. 1991.

O gênero Epigloeosphaera foi descrito por Komárková-Legnerová (1991) com base em populações planctônicas provenientes de lagos nórdicos (Suécia). A espécie-tipo foi originalmente descrita como Aphanothece glebulenta Zalessky e reposicionada em Epigloeosphaera baseado na posição das células no envelope mucilaginoso.

Segundo Komárek \& Anagnostidis (1998), o gênero é caracterizado por colônias microscópicas, esféricas, ovais ou alongadas; células dispostas esparsa e irregularmente na superfície da colônia; mucilagem incolor e homogênea; células ovais ou cilíndricas; sem aerótopos; reprodução por meio de fragmentação da colônia.

De acordo com Komárek \& Hauer (2009), o gênero tem apenas três espécies descritas e o presente estudo documentou a ocorrência de um representante do gênero que, provavelmente, venha a ser uma novidade para a ciência.

\section{Epigloeosphaera sp.}

(Figs. 4C, 10A)

Colônias microscópicas, esféricas, ovais ou alongadas, 25,0-58,0 $\mu \mathrm{m}$ diâm., 46,2132,0 $\mu \mathrm{m}$ compr.; células dispostas irregularmente na superfície da colônia; mucilagem homogênea, firme, incolor, margem difluente; células ovais a cilíndricas, com extremidades arredondadas, 0,8-1,3 $\mu \mathrm{m}$ diâm., 1,5-2,0 $\mu \mathrm{m}$ compr., 1,4 a 2,5 vezes mais longas que largas; conteúdo celular verde-azulado, homogêneo; sem aerótopos.

O gênero Epigloeosphaera possui apenas três espécies descritas (E. brasilica Azevedo et al., E. filamentosa Komárek et Cronberg e E. glebulenta (Zalessky) KomárkováLegnerová). Comparando a população estudada com as demais espécies do gênero, verificouse que Epigloeosphaera sp. possui valores de diâmetro celular semelhantes a E. glebulenta $(0,8-2,0 \mu \mathrm{m})$. Quanto ao comprimento celular, as espécies do gênero apresentam células mais longas que as observadas em Epigloeosphaera sp., cujas medidas formam um intervalo mais amplo de variação. Epigloeosphaera sp. também difere das demais espécies do gênero pela disposição das células na colônia, que estão dispostas de maneira mais densa na superfície da mucilagem colonial. Os espécimes analisados diferem também de E. filamentosa pelas dimensões de suas células que, segundo Komárek \& Anagnostidis (1998), são 2,8-32,0 x 2,8$4,2 \mu \mathrm{m}$. 
Epigloeosphaera brasilica foi descrita a partir de material proveniente de região tropical e E. glebulenta, de região temperada, embora também tenha sido registrada em região tropical por Tucci et al. (2006).

Considerando as características citadas acima, verificou-se que existem diferenças importantes entre os espécimes encontrados e as espécies descritas para o gênero em questão. Assim, a população estudada e identificada como Epigloeosphaera sp. constitui a primeira ocorrência do gênero para o Rio Grande do Sul, tratando-se, possivelmente, de um novo táxon para a ciência. Entretanto, mais estudos devem ser feitos para confirmar tal hipótese.

Material examinado: HAS 104202, HAS 104343, HAS 104351, HAS 104352.

Tabela 5: Comparação entre Epigloeosphaera sp. e as demais espécies do gênero.

\begin{tabular}{|c|c|c|c|c|}
\hline & E. brasilica & E. filamentosa & E. glebulenta & Epigloeosphaera sp. \\
\hline Colônias & microscópicas & microscópicas & microscópicas & microscópicas \\
\hline Forma & esféricas & alongadas & esféricas, ovais & $\begin{array}{l}\text { esféricas, ovais e } \\
\text { alongadas }\end{array}$ \\
\hline Dimensões $(\mu \mathrm{m})$ & até 60,0 & - & até 35,0 & $\begin{array}{l}25,0-58,0 \times \\
46,2-132,0\end{array}$ \\
\hline $\begin{array}{l}\text { Disposição das } \\
\text { células na } \\
\text { mucilagem }\end{array}$ & $\begin{array}{l}\text { esparsa e } \\
\text { irregularmente }\end{array}$ & $\begin{array}{l}\text { esparsa e } \\
\text { irregularmente }\end{array}$ & $\begin{array}{l}\text { esparsa e } \\
\text { irregularmente }\end{array}$ & $\begin{array}{l} \pm \text { esparsa e } \\
\text { irregularmente }\end{array}$ \\
\hline Mucilagem & $\begin{array}{l}\text { homogênea, firme } \\
\text { e incolor }\end{array}$ & $\begin{array}{l}\text { homogênea, firme } \\
\text { e incolor }\end{array}$ & $\begin{array}{l}\text { homogênea, firme } \\
\text { e incolor }\end{array}$ & $\begin{array}{l}\text { homogênea, firme e } \\
\text { incolor }\end{array}$ \\
\hline $\begin{array}{l}\text { Contorno } \\
\text { Células }\end{array}$ & evidente & difluente & difluente & difluente \\
\hline Forma & cilíndrica & oval a cilíndrica & oval a cilíndrica & oval a cilíndrica \\
\hline $\begin{array}{l}\text { Dimensões }(\mu \mathrm{m}) \\
\mathrm{RC} / \mathrm{L}\end{array}$ & $0,6-0,8 \times 1,6-4,0$ & $2,8-3,2 \times 2,8-4,2$ & $0,8-2,0 \times 1,5-4,0$ & $\begin{array}{l}0,8-1,3 \times 1,5-2,0 \\
1,4 \text { a } 2,5\end{array}$ \\
\hline $\begin{array}{l}\text { Conteúdo } \\
\text { celular }\end{array}$ & $\begin{array}{l}\text { verde-azulado, } \\
\text { homogêneo }\end{array}$ & $\begin{array}{l}\text { verde-azulado, } \\
\text { homogêneo }\end{array}$ & $\begin{array}{l}\text { verde-azulado, } \\
\text { homogêneo }\end{array}$ & $\begin{array}{l}\text { verde-azulado, } \\
\text { homogêneo }\end{array}$ \\
\hline Aerótopos & ausente & ausente & ausente & ausente \\
\hline Hábitat & plâncton & plâncton & plâncton & plâncton \\
\hline
\end{tabular}

\section{Gloeothece Nägeli, 1849.}

Espécie-tipo: Gloeothece linearis Nägeli, Neue Denkschr. Allg. Schweiz Ges. Nat., v. 57, n. 2, p. 57.1849.

O gênero Gloeothece caracteriza-se por apresentar células ovais a bacilariformes, solitárias ou em pequenos grupos constituídos por 2-4 (ou mais) células que, obrigatoriamente, possuem envelope mucilaginoso individual. As células ou grupos de células são envoltos por mucilagem hialina, lamelada incolor ou intensamente colorida, com margem evidente. A divisão celular ocorre em único plano transversal ao eixo longitudinal da célula e a reprodução se dá através da desintegração da colônia. As colônias de Gloeothece 
normalmente são pequenas, às vezes formadas por agregados de colônias e variam de microscópicas a macroscópicas (KOMÁREK \& ANAGNOSTIDIS, 1998).

As principais características que distinguem as espécies de Gloeothece são as dimensões celulares e o hábitat. A maioria das espécies é conhecida de ambientes aerofíticos, principalmente rochas úmidas de regiões montanhosas e poucas espécies crescem no metafíton de corpos d'água oligotróficos com vegetação aquática abundante (KOMÁREK \& HAUER, 2009).

Pelo sistema de classificação de Hoffmann et al. (2005), Gloeothece está classificado como gênero da família Cyanobacteriaceae (subclasse Oscillatoriophycidae), baseado em estudos moleculares com o gene RNAr 16S e estudos ultraestruturais (disposição dos tilacoides na célula).

No presente estudo apenas uma espécie do gênero foi documentada, G. incerta Skuja.

Gloeothece incerta Skuja, Nova Acta Reg. Soc. Scient. Upsal., Sér. 4, v. 18, n. 3, p. 37. 1964.

(Figs. 4D, 10B)

Colônias microscópicas, esféricas, alongadas ou irregulares, 25,0-42,0 $\mu \mathrm{m}$ diâm., 25,073,0 $\mu$ m compr.; células dispostas irregular e densamente aglomeradas na colônia; mucilagem firme, incolor ou acastanhada, lamelada, margem evidente; células ovais ou alongadas, com extremidades arredondadas, 1,5-2,0 $\mu \mathrm{m}$ diâm., 2,0-3,0 $\mu \mathrm{m}$ compr., 1,2 a 1,7 vez mais longas que largas; conteúdo celular verde-azulado, homogêneo ou levemente granuloso; com aerótopos.

A espécie foi descrita a partir de material metafítico de água doce. Segundo Skuja (1964), a espécie caracteriza-se por apresentar colônias formadas por células individualmente envolvidas por envelope mucilaginoso ou por grupos de células circundadas por uma mucilagem comum. No presente estudo, os espécimes analisados apresentaram sempre células individualmente envoltas por envelope mucilaginoso lamelado formando as colônias. As dimensões celulares observadas ampliam o intervalo referido pelo autor para a espécie (1-1,51,7 x 1,5-2,5 $\mu \mathrm{m})$. Com base nas características citadas acima, além de outras referidas para a espécie, a população observada foi identificada com G. incerta.

Gloeothece incerta é morfologicamente semelhante a G. subtilis Skuja, principalmente quanto à estrutura da colônia e disposição das células na mesma, no entanto, as dimensões celulares são inferiores em G. subtilis (0,4-0,6 x 0,8-2,0 $\mu \mathrm{m})$ (SKUJA, 1964). 
Embora a espécie seja comum no metafíton, no presente estudo, os espécimes foram observados no plâncton do banhado da fazenda Rincão do Anastácio, que apresenta grande quantidade de vegetação.

Material examinado: HAS 104369.

\section{MERISMOPEDIACEAE Komárek et Anagnostidis, 1995.}

Merismopediaceae caracteriza-se por apresentar células solitárias ou formando colônias irregulares, planas ou esféricas; mucilagem incolor e difluente; células esféricas, obovoides, ovais ou bacilariformes; a reprodução ocorre pela desintegração da colônia ou, raramente, pela liberação de células solitárias (KOMÁREK \& ANAGNOSTIDIS, 1998).

Komárek \& Anagnostidis (1998) definiram que a família engloba as espécies que sofrem divisão celular em apenas dois planos em sucessivas gerações, sendo constituída por 15 gêneros, divididos em duas subfamílias, Merismopedioideae (8) e Gomphosphaerioideae (7), segundo o tipo de colônia e a disposição das células na mucilagem colonial.

De acordo com o sistema de classificação apresentado por Hoffmann et al. (2005), Merismopediaceae também é formada por 15 gêneros, porém com algumas alterações em relação à classificação de Komárek \& Anagnostidis (1998). Segundo estes autores, os gêneros Microcrocis Richter, Pannus Hickel, Snowella Elenkin, Woronichinia Elenkin e Gomphosphaeria Kützing são reposicionados em outras famílias de Synechococcophycideae e de Oscillatoriophycideae. Já os representantes de Chroococcus subgênero Limnococcus Nägeli, Eucapsis Clements et Shantz, Lithococcus Ercegovic, Lithomyxa Howe e Paracapsa Naumann são incorporados em Merismopediaceae e os demais gêneros, Aphanocapsa Nägeli, Coccopedia Troickaja, Coelomoron Buell, Coelosphaeriopsis Lemmermann, Coelosphaerium Nägeli, Cyanotetras Hindák, Mantellum Dangeard, Merismopedia Meyen, Siphonosphaera Hindák e Synechocystis Sauvageau, permanecem na família.

No presente estudo foram registradas 15 espécies pertencentes a seis gêneros, destacando-se Merismopediaceae entre as demais famílias de Synechococcophycidae por apresentar o maior número de táxons registrados (12 classificados em Merismopedioideae e três em Gomphosphaerioideae). 


\section{CHAVE PARA IDENTIFICAÇÃO DAS SUBFAMÍLIAS ENCONTRADAS}

1. Colônias tabulares ou globosas, células dispostas irregularmente. Merismopedioideae

1. Colônias globosas, células dispostas na periferia Gomphosphaerioideae

Subfamília Merismopedioideae (Elenkin) Komárek et Anagnostidis, 1986.

\section{CHAVE PARA IDENTIFICAÇÃO DOS GÊNEROS ENCONTRADOS}

1. Colônias globosas. Aphanocapsa

1. Colônias tabulares .2

2. Células esféricas, hemisféricas ou alongadas, dispostas em fileiras regulares Merismopedia

2. Células ovais ou poligonais, não dispostas em fileiras regulares Microcrocis

\section{Aphanocapsa Nägeli, 1849}

Espécie-tipo: Aphanocapsa parietina Nägeli, Gatt. Einz. Algen., p. 52. 1849.

O gênero Aphanocapsa é caracterizado por desenvolver colônias microscópicas ou macroscópicas, esféricas ou alongadas, formadas por numerosas células dispostas esparsa ou densamente na colônia; mucilagem incolor, homogênea, firme, margem usualmente não evidente; as células são esféricas ou hemisféricas após a divisão; sem aerótopos; reprodução através da desintegração da colônia (KOMÁREK \& ANAGNOSTIDIS, 1998).

Trata-se de um gênero bastante conhecido e com ampla distribuição e diversidade (KOMÁREK \& ANAGNOSTIDIS, 1998). Grande parte dos representantes é planctônico e sua taxonomia é confusa. A simplicidade morfológica exibida pelas espécies que o compõem é um fator que dificulta a distinção dos táxons e, segundo Komárek \& Kling (1991), as características utilizadas na sua identificação, como dimensão e disposição celular na mucilagem, bem como a forma da colônia, geram problemas quanto à delimitação das espécies.

Starmach (1966) considera Aphanocapsa como sinônimo de Microcystis, baseado no fato dos dois gêneros apresentarem células esféricas que se dispõem irregularmente na mucilagem. Embora Aphanocapsa, quando comparada com Microcystis, apresente células dispostas mais frouxamente na colônia, Komárek e Anagnostidis (1986) consideram que este critério não é suficiente para distingui-los, pois é comum a ocorrência de colônias em fase de transição em relação à disposição das células na colônia. 
Segundo Komárek \& Anagnostidis (1986), o principal caráter que delimita os dois gêneros é o número de planos de divisão celular (Aphanocapsa divide-se em dois planos perpendiculares em sucessivas gerações e Microcystis, em três planos). Além disso, as espécies de Microcystis possuem a capacidade de produzir aerótopos e Aphanocapsa não (CRONBERG \& KOMÁREK, 1994).

\section{Chave para identificação das espécies encontradas}

1. Células com até $1,0 \mu \mathrm{m}$ diâm. .2

1. Células maiores que $1,0 \mu \mathrm{m}$ diâm. 3

2. Células dispostas esparsa e irregularmente na colônia A. delicatissima

2. Células densamente aglomeradas no centro da colônia A. holsatica

3. Células densamente aglomeradas no centro da colônia .4

3. Células dispostas esparsa e irregularmente na colônia .5

4. Células 1,0-1,5 $\mu \mathrm{m}$ diâm. A. incerta

4. Células 1,5-2,2 $\mu \mathrm{m}$ diâm. A. cf. incerta

5. Células 2,0-3,0 $\mu \mathrm{m}$ diâm. A. koordersii

5. Células com até 2,0 $\mu \mathrm{m}$ diâm. 6

6. Colônias esféricas ou ovais A. eclachista

6. Colônias alongadas e irregulares A. conferta

Aphanocapsa conferta (W. et G. S. West) Komárková-Legnerová et Cronberg, Algolog. Stud., v. 72, p.21. 1994

Basônimo: Aphanocapsa elachista var. conferta W. et G. S. West, J. Linn. Soc. (Bot.), v. 40, p.432. 1912 .

(Figs. 4E, 10C)

Colônias microscópicas alongadas ou irregulares, 55,0-97,5 $\mu \mathrm{m}$ diâm., 60,0-350,0 $\mu \mathrm{m}$ compr.; células dispostas esparsa e irregularmente na colônia; mucilagem homogênea, firme, incolor, margem difluente; células esféricas ou hemisféricas após a divisão, 1,5-2,0 $\mu \mathrm{m}$ diâm.; conteúdo celular verde azulado, homogêneo.

Originalmente, Aphanocapsa conferta foi descrita como uma variedade de Aphanocapsa elachista W. et G. S. West, diferindo de Aphanocapsa elachista var. elachista pelas dimensões das colônias e pela distribuição das células na mesma: enquanto a primeira apresentava colônias menores e células bastante distantes umas das outras, a segunda possuía colônias maiores e células mais próximas (GEITLER, 1932). 
Aphanocapsa elachista var. conferta foi elevada a espécie por Komárková-Legnerová \& Cronberg (1994), recebendo a denominação de A. conferta, considerando, além do tamanho das colônias e da disposição das células, a distribuição, onde A. conferta é uma espécie de região temperada e A. elachista, de região tropical.

Embora os espécimes observados tenham apresentado colônias maiores e com formato mais irregulares do que as referidas para A. conferta por Komárkova-Legnerová, as demais características estão de acordo com as descritas para a espécie. Nas regiões amostradas, os espécimes foram observados no plâncton e no metafíton.

Material examinado: HAS 104343, HAS 104348, HAS 104351.

Aphanocapsa delicatissima W. et G. S. West, J. Linn. Soc. (Bot.), v. 40, p. 431. 1912.

(Fig. 4F)

Colônias microscópicas, esféricas, ovais ou alongadas, 13,6-78,7 $\mu \mathrm{m}$ diâm., 29,6168,7 $\mu \mathrm{m}$ compr.; células dispostas esparsa e irregularmente na colônia; mucilagem homogênea, firme, incolor, margem difluente; células esféricas, 0,8-1,0 $\mu \mathrm{m}$ diâm.; conteúdo celular verde azulado, homogêneo.

As características morfológicas apresentadas pelos espécimes analisados estão de acordo com as referidas para Aphanocapsa delicatissima por Komárek \& Anagnostidis (1998) e foram documentadas apenas para o plâncton.

Material examinado: HAS 104132, HAS 104235, HAS 104352

Aphanocapsa elachista W. et G. S. West, J. Linn. Soc. (Bot.), v. 30, p. 276.1894.

(Fig. 5A)

Colônias microscópicas, esféricas ou ovais, 10,5-60,0 $\mu \mathrm{m}$ diâm., 29,6-168,7 $\mu \mathrm{m}$ compr.; células dispostas esparsa e irregularmente na colônia; mucilagem homogênea, firme, incolor, margem difluente; células esféricas ou hemisféricas após a divisão, 1,4-2,0 $\mu$ m diâm.; conteúdo celular verde azulado, homogêneo.

Aphanocapsa elachista e A. conferta são espécies próximas morfologicamente. Os espécimes analisados e identificados como A. elachista diferem dos espécimes identificados como $A$. conferta, no presente estudo, pela disposição das células na mucilagem que, em $A$. elachista, apresentaram células mais distantes umas das outras e pelo formato das colônias. $A$. elachista também é muito semelhante morfologicamente a A. delicatissima, diferindo apenas nas dimensões celulares.

Os espécimes foram registrados tanto no plâncton quanto no metafíton. 
Material examinado: HAS 104103, HAS 104132, HAS 104202, HAS 104348.

Aphanocapsa holsatica (Lemmermann) Cronberg \& Komárek, Algol. Studies, v. 75, p. 327. 1994.

Basônimo: Clathrocystis holsatica Lemmermann, ForschBer. Biol. Stn Plön, v. 10, p. 150. 1903.

(Fig. 5C)

Colônias microscópicas, alongadas ou irregulares, às vezes clatradas, 42,3-53,8 $\mu \mathrm{m}$ diâm., 55,0-215,6 ㅆm compr.; células dispostas densa e irregularmente na colônia; mucilagem homogênea, firme, incolor, margem difluente; células esféricas, 0,8-1,0 $\mu \mathrm{m}$ diâm.; conteúdo celular verde azulado, homogêneo.

As populações observadas e identificadas como A. holsatica possuíam características que as aproximavam de A. delicatissima e a A. incerta. Aphanocapsa holsatica e A. delicatissima possuem dimensões celulares semelhantes, no entanto, comparando as populações analisadas, os espécimes identificados como A. holsatica exibiram colônias de tamanhos maiores e formatos mais variados, algumas sendo lobadas ou clatradas e suas células estavam mais densamente organizadas na colônia.

Dentre os corpos d'água estudados, A. holsatica foi registrada tanto para o plâncton como para o metafíton.

Material examinado: HAS 104106, HAS 104163.

Aphanocapsa incerta (Lemmermann) Cronberg et Komárek, Algol. Studies, v. 75, p. 327. 1994.

Basônimo: Polycystis incerta Lemmermann, Hedwigia, v. 38, p. 20-38. 1899.

(Figs. 5B, 10D)

Colônias microscópicas, esféricas ou ovais, 40,0-52,0 $\mu$ m diâm., 42,0-64,5 $\mu \mathrm{m}$ compr.; células densamente agregadas no centro da colônia; mucilagem homogênea, firme, incolor, margem difluente; células esféricas, 1,0-1,5 $\mu \mathrm{m}$ diâm.; conteúdo celular verde azulado, homogêneo.

Aphanocapsa incerta é uma espécie caracterizada por apresentar colônias esféricas ou elipsoides e células densamente agrupadas no centro da colônia. A população identificada como A. incerta apresentava características morfológicas que estão de acordo com as descritas por Komárek \& Anagnostidis (1998), no entanto, as dimensões celulares registradas para os espécimes observados não apresentaram uma variação ampla como referida para a espécie $(0,5-2,0 \mu \mathrm{m})$. 
Aphanocapsa incerta também pode ser confundida com A. holsatica, pois apresentam medidas celulares semelhantes, no entanto as populações das duas espécies analisadas, no presente estudo mostraram diferenças no tamanho e forma das colônias, sendo menores e esféricas ou ovais nos espécimes identificados como A. incerta.

No sistema de lagoas analisado, A. incerta foi registrada apenas no plâncton.

Material examinado: HAS 104351, HAS 104352.

Aphanocapsa cf. incerta (Lemmermann) Cronberg et Komárek, Algolog. Stud., v. 75, p. 327. 1994.

Basônimo: Polycystis incerta Lemmermann, Hedwigia, v. 38, p. 20-38. 1899.

(Figs. 5E-F, 10E-G)

Colônias microscópicas, esféricas ou ovais, 32,0-60,3 $\mu \mathrm{m}$ diâm., 40,0-96,7 $\mu \mathrm{m}$ compr.; células densamente agregadas na colônia; mucilagem homogênea, firme, incolor, margem difluente; células esféricas, 1,5-2,2 $\mu$ m diâm.; conteúdo celular verde azulado, homogêneo.

As populações analisadas exibiram características métricas que estão de acordo com as referidas para Aphanocapsa incerta por Komárek \& Anagnostidis (1998). As células apresentaram-se densamente e irregularmente organizadas na colônia. Apesar das características citadas anteriormente estarem de acordo com a descrição de A. incerta, a população estudada foi identificada como A. cf. incerta por apresentar características na colônia que as diferem da população identificada como A. incerta. A mucilagem das colônias de $A$. cf. incerta se estende até o limite de distribuição das células, diferindo dos espécimes denominados de $A$. incerta, que apresentaram colônias com a mucilagem formando uma margem ampla. Normalmente as colônias de A. cf. incerta apresentaram-se aglomeradas, o que não foi observado em $A$. incerta, cujas colônias sempre foram encontradas solitárias.

Aphanocapsa cf. incerta foi encontrada apenas na lagoa do Charutão, no plâncton.

Material examinado: HAS 104202.

Aphanocapsa koordersii StrØm, Nyt. Mag. Naturv., v. 61, p. 128. 1923.

(Figs. 5D, 11A)

Colônias microscópicas, esféricas ou ovais, 49,0-219,0 $\mu \mathrm{m}$ diâm., 68,7-254,2 $\mu \mathrm{m}$ compr.; células dispostas esparsa e irregularmente na colônia; mucilagem homogênea, firme, incolor, margem difluente; células esféricas ou hemisféricas após a divisão, 2,0-3,0 $\mu$ m diâm.; conteúdo celular verde azulado, homogêneo. 
Os espécimes analisados possuem as mesmas características morfológicas descritas para Aphanocapsa koordersii por StrØm (1923). As populações estudadas apresentaram uma variação métrica celular mais ampla que a referida para a espécie $(2,2-2,8 \mu \mathrm{m})$, no entanto, o diâmetro da maioria das células variou entre 2,5-2,7 $\mu \mathrm{m}$.

Aphanocapsa koordersii pode ser facilmente confundida com Aphanocapsa planctonica (G. M. Smith), pois apresentam as mesmas características, diferindo apenas na distribuição geográfica: $A$. planctonica é conhecida por ocorrer em regiões temperadas e $A$. koordersii foi descrita a partir de material de região tropical (KOMÁREK \& ANAGNOSTIDIS, 1998). Embora as populações observadas tenham ocorrido em locais de características diferentes da área de origem da espécie (região montanhosa, Indonésia), as demais características corroboram para a identificação como A. koordersii.

As populações de Aphanocapsa koordersii registradas no presente trabalho ocorreram tanto no plâncton como no metafíton.

Material examinado: HAS 104118, HAS 104124, HAS 104195, HAS 104202, HAS 104203, HAS 104343, HAS 104352, HAS 104356, HAS 104369, HAS 104376, HAS 104381, HAS 104420, HAS 104442. 


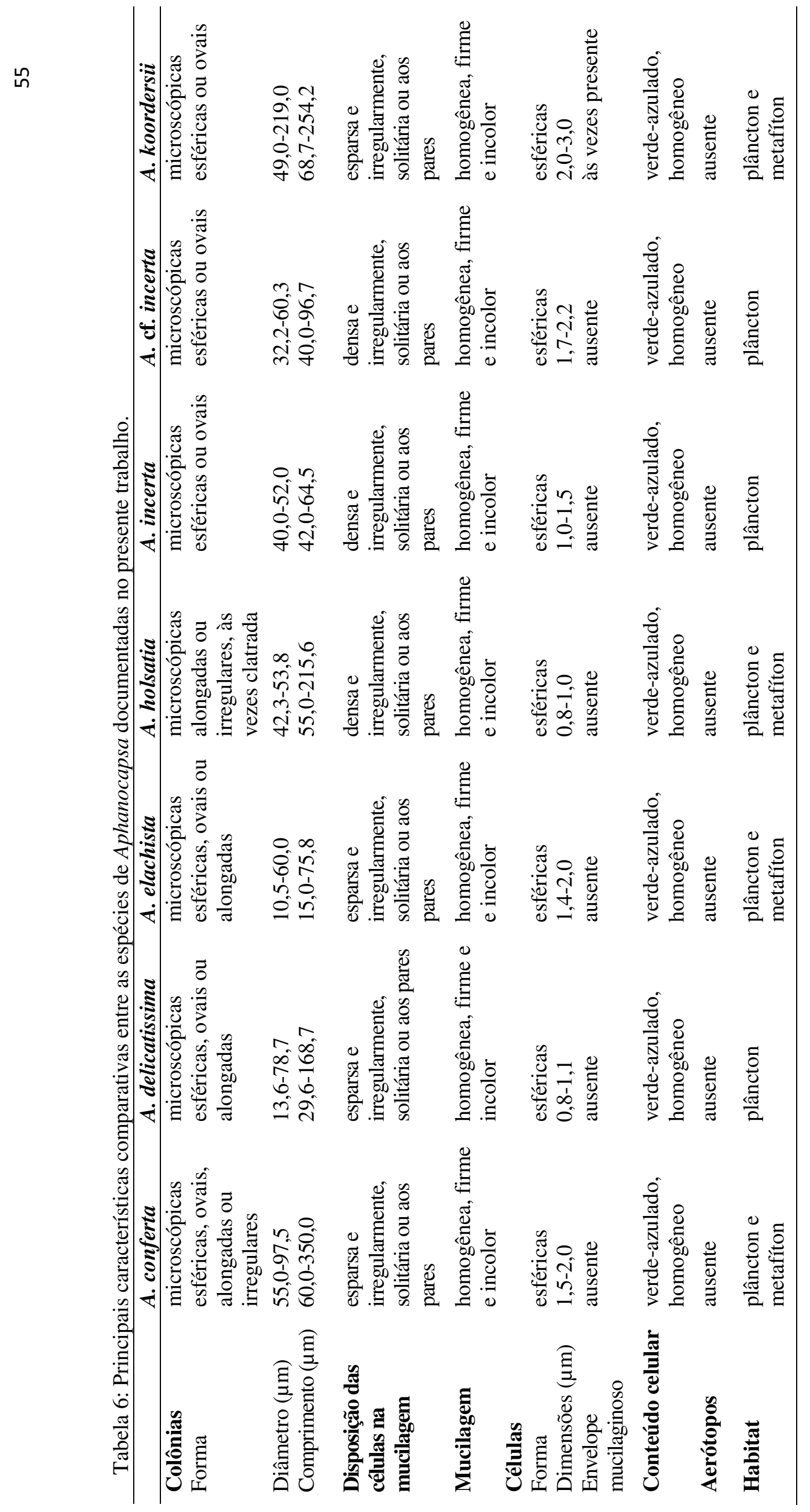




\section{Merismopedia Meyen, 1839.}

Espécie-tipo: Merismopedia punctata Meyen, Neues Syst. Pfl.- Physiol., v. 3, p. 440. 1839.

O gênero Merismopedia caracteriza-se por desenvolver colônias microscópicas ou, raramente, macroscópicas, tabulares, quadráticas a retangulares, com células em fileiras regulares, densa ou esparsamente arranjadas; mucilagem incolor, homogênea; células esféricas a ovais ou hemisféricas após a divisão; conteúdo celular homogêneo ou granuloso; com ou sem aerótopos; as células se dividem em dois planos em sucessivas gerações; reprodução através da desintegração da colônia (KOMÁREK \& ANAGNOSTIDIS, 1998).

As espécies que compõem Merismopedia podem ser encontradas no metafíton ou no plâncton de corpos d'água doce, em ambientes halófilos ou em fontes termais. Trata-se de um gênero amplamente distribuído, mas algumas espécies apresentam uma distribuição ecologicamente e geograficamente limitada (KOMÁREK \& HAUER, 2009).

\section{Chave para identificação das espécies encontradas}

1. Células alongadas M. elegans

1. Células esféricas ou hemisféricas 2

2. Células 1,0-1,4 $\mu \mathrm{m}$ diâm. M tenuissima

2. Células maiores 3

3. Célula 2,5-3,5 $\mu$ m diâm. M. punctata

3. Célula 3,5-6,0 $\mu \mathrm{m}$ diâm. M. glauca

Merismopedia elegans A. Braun, In Kützing, Spec. Algar., p. 472. 1849.

(Figs. 6C, 11C)

Colônias tabulares, planas, retangulares, 21,6-72,0 $\mu \mathrm{m}$ diâm., 30,0-79,6 $\mu \mathrm{m}$ compr.; células dispostas próximas umas das outras, em grupos de 8-64 células na colônia; mucilagem homogênea, firme, incolor, margem difluente; células ovais ou hemisféricas após a divisão, 1,2 a 1,7 vez mais longas que largas, 4,5-6,5 $\mu \mathrm{m}$ diâm., 6,0-8,0 $\mu \mathrm{m}$ compr.; conteúdo celular verde-azulado, homogêneo; sem aerótopos.

As características morfológicas analisadas estão de acordo com as descritas na literatura, exceto pelo diâmetro celular menor do que o limite métrico mínimo referido para a espécie (5,0-7,0 $\mu \mathrm{m}$ - GEITLER, 1932; DESIKACHARY, 1959; KOMÁREK \& ANAGNOSTIDIS, 1998). No 
entanto, embora tenham sido registradas células menores $(4,5 \mu \mathrm{m})$, o diâmetro celular da maioria das células variou entre 5,0-6,0 $\mu \mathrm{m}$.

A ocorrência do táxon foi documentada tanto no plâncton quanto no metafíton.

Material examinado: HAS 104171, HAS 104195, HAS 104197, HAS 104202, HAS 104235, HAS 104425, HAS 104451.

Merismopedia glauca (Ehrenberg) Kützing, Phycol. Germ., p. 142. 1845.

Basônimo: Gonium glaucum Eherenberg, Infunsions, p. 58. 1838.

(Figs. 6D, 11D)

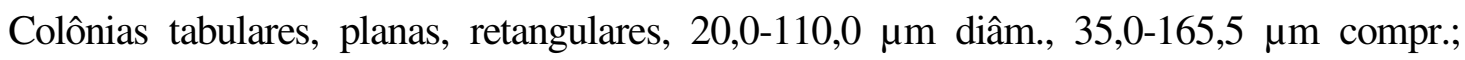
células dispostas próximas umas das outras, em grupos de 16-192 células na colônia; mucilagem homogênea, firme, incolor, margem difluente; células esféricas ou hemisféricas após a divisão, 3,56,0 ㅆm diâm.; conteúdo celular verde-azulado, homogêneo; sem aerótopos.

As populações observadas apresentaram características morfológicas que estão de acordo com as referidas para a espécie na literatura consultada (GEITLER, 1932; KOMÁRKOVÁLEGNEROVÁ \& CRONBERG, 1994; KOMÁREK \& ANAGNOSTIDIS, 1998).

Segundo Komárková-Legnerová \& Cronberg (1994), a espécie é encontrada principalmente no metafíton, ocorrendo ocasionalmente no plâncton ou frequentemente em lagos rasos. No presente trabalho, as populações observadas foram registradas tanto no metafíton quanto no plâncton.

Material examinado: HAS 104142, HAS 104171, HAS 104172, HAS 104197, HAS 104202, HAS 104203, HAS 104240, HAS 104416, HAS 104427, HAS 104436, HAS 104446, HAS 104450, HAS 104451, HAS 104457.

Merismopedia punctata Meyen, Neues Syst. Pfl. - Physiol., v. 3, p. 440. 1839.

(Fig. 6B)

Colônias tabulares, planas, retangulares, 15,0-35,0 ㅆm diâm., 20,0-53,0 $\mu$ m compr., com 1664 células; células dispostas um pouco distante umas das outras; mucilagem homogênea, firme, incolor, margem difluente; células esféricas ou hemisféricas após a divisão, 2,5-3,5 $\mu \mathrm{m}$ diâm.; conteúdo celular verde-azulado, homogêneo; sem aerótopos.

As características morfológicas apresentadas pelas populações observadas estão de acordo com as referidas para a espécie (GEITLER, 1932; KOMÁREK, 1998).

Merismopedia punctata é uma espécie comum e pode ser confundida com M. hyalina (Ehrenberge) Kützing ou com M. glauca (Ehrenberge) Kützing, por apresentarem características morfológicas semelhantes. $M$. hyalina difere de $M$. punctata por exibir menor número de células nas 
colônias e pela disposição um pouco irregular das células (SANT'ANNA et al., 2004). M. glauca apresenta células com uma variação métrica maior, podendo apresentar diâmetros superiores às referidas para M. punctata.

Merismopedia punctata é um componente comum no plâncton de lagos, no entanto, no presente estudo, os espécimes analisados foram registrados também no metafíton.

Material examinado: HAS 104195, HAS 104197, HAS 104202, HAS 104362.

Merismopedia tenuissima Lemmermann, Bot. Zbl., v. 76, p. 154. 1898.

(Fig. 6A)

Colônias tabulares, planas, quadráticas, 14,0-18,5 $\mu \mathrm{m}$ diâm., 16,0-20,0 $\mu \mathrm{m}$ compr., com 1664 células; células dispostas próximas umas das outras; mucilagem homogênea, firme, incolor, margem difluente; células esféricas ou hemisféricas após a divisão, 1,0-1,4 $\mu \mathrm{m}$ diâm.; conteúdo celular verde-azulado, homogêneo; sem aerótopos.

Os espécimes analisados estão de acordo com as características morfológicas e métricas referidas para a espécie por Geitler (1932), Desikachary (1959) e Komárek \& Anagnostidis (1998).

A espécie mais próxima de $M$. tenuissima é M. africana Komárek et Cronberg, ambas apresentam células com dimensões pequenas e diferem pelas colônias tabulares arqueadas observadas em M. africana (KOMÁREK \& CRONBERG, 2001).

Merismopedia tenuissima é uma espécie comum no plâncton e, segundo Komárek \& Anagnostidis (1998), sua ocorrência é mais frequente durante as estações quentes. No entanto, os espécimes observados foram registrados tanto no plâncton como no metafíton e somente nas amostras coletadas em maio com as temperaturas da água entre 15 e $16,2^{\circ} \mathrm{C}$.

Material examinado: HAS 104132, HAS 104163.

Tabela 7: Principais características comparativas entre as espécies de Merismopedia documentadas no presente trabalho.

\begin{tabular}{lllll}
\hline Colônia & M. elegans & M.glauca & M.punctata & M. tenuissima \\
$\begin{array}{l}\text { Células } \\
\text { Forma }\end{array}$ & $\begin{array}{l}\text { tabulares, planas, } \\
\text { retangulares }\end{array}$ & $\begin{array}{l}\text { tabulares, planas, } \\
\text { retangulares }\end{array}$ & $\begin{array}{l}\text { tabulares, planas, } \\
\text { retangulares }\end{array}$ & $\begin{array}{l}\text { tabulares, planas, } \\
\text { quadráticas }\end{array}$ \\
& $\begin{array}{l}\text { ovais ou } \\
\text { hemisféricas após } \\
\text { a divisão } \\
\text { próximas entre si }\end{array}$ & $\begin{array}{l}\text { esféricas ou } \\
\text { hemisféricas após a } \\
\text { divisão } \\
\text { próximas entre si }\end{array}$ & $\begin{array}{l}\text { esféricas ou } \\
\text { hemisféricas após a } \\
\text { divisão } \\
\text { um pouco distantes } \\
\text { entre si }\end{array}$ & $\begin{array}{l}\text { esféricas ou } \\
\text { hemisféricas } \\
\text { após a divisão } \\
\text { próximas entre si }\end{array}$ \\
$\begin{array}{l}\text { Dimensões } \\
(\mu \mathrm{m})\end{array}$ & $\begin{array}{l}\text { 4,5-6,5 x 6,0-8,0 } \\
\text { RC/L }\end{array}$ & $3,5-6,0$ & $2,5-3,5$ & $1,0-1,4$ \\
Hábitat & $1,2-1,7$ & - & - & - \\
& $\begin{array}{l}\text { plâncton e } \\
\text { metafíton }\end{array}$ & $\begin{array}{l}\text { plâncton e } \\
\text { metafíton }\end{array}$ & $\begin{array}{l}\text { plâncton e } \\
\text { metafíton }\end{array}$ & $\begin{array}{l}\text { plâncton e } \\
\text { metafíton }\end{array}$ \\
\hline
\end{tabular}




\section{Microcrocis Richter, 1892.}

Espécie-tipo: Microcrocis dieteli Richter in Hauk \& Richter, Phyk. Univ., p. 548. 1892.

O gênero Microcrocis carateriza-se por desenvolver colônias tabulares, planas, micro a macroscópicas, compostas por células densamente arranjadas na colônia; células alongadas com extremidades arredondadas, quando na periferia da colônia, e poligonais no centro, eixo maior orientado perpendicularmente ao plano da colônia; divisão celular em dois planos em sucessivas gerações; reprodução através da desintegração da colônia.

Trata-se de um gênero conhecido de regiões temperadas, com poucos relatos para regiões tropicais. Suas espécies são principalmente epipélicas e metafíticas, sendo encontradas em pequenos corpos d'água com grande quantidade de vegetação e duas espécies são relatadas ocorrendo em ambientes salinos. As características que diferem suas espécies são: morfologia da colônia, dimensões celulares e hábitat onde ocorrem (KOMÁREK \& HAUER, 2009).

Na classificação de Komárek \& Anagnostidis (1998), Microcrocis pertence à família Merismopediaceae pelo fato de apresentar divisão celular em dois planos, no entanto, segundo Hoffmann et al. (2005), Microcrocis é classificado em Cyanobacteriaceae (subclasse Oscillatoriophycidae), baseado em características ultraestruturais (tilacoides dispostos radialmente na célula).

Microcrocis pulchella (Buell) Geitler in Engler \& Prantl, Natürl. Planzenfam., p. 56. 1942.

Basônimo: Holopedia pulchella Buell, Bull. Torrey bot. Cl., v. 65, p. 385. 1938.

(Figs. 6E-F, 11E)

Colônias tabulares, planas, alongadas, irregulares, 40,0-68,5 $\mu \mathrm{m}$ diâm., 52,0-102,0 $\mu \mathrm{m}$ compr.; células dispostas irregularmente e próximas umas das outras; mucilagem homogênea, incolor e difluente; células poligonais, arredondadas, quando nas extremidades da colônia, hemisféricas após a divisão, 3,0-4,0 $\mu \mathrm{m}$ diâm., 4,4-5,2 $\mu \mathrm{m}$ compr., células alongadas em vista lateral (4,0-4,8 $\mu$ m compr.); conteúdo celular verde-azulado, homogêneo; sem aerótopos.

De acordo com Buell (1938), a espécie foi descrita baseada na população encontrada em lago de Minnesota, onde os espécimes foram observados entre outras cianobactérias. Os espécimes analisados, no presente estudo, apresentaram características morfométricas que estão de acordo com as referidas para M. pulchella em sua descrição original.

Embora a espécie tenha sido descrita a partir de material proveniente do metafíton, as populações estudadas foram registradas apenas no plâncton, fato também observado por Werner \& Sant'Anna (2006).

Material examinado: HAS 104171, HAS 104348. 
Subfamília Gomphosphaerioideae (Elenkin) Komárek et Anagnostidis, 1988.

\section{CHAVE PARA IDENTIFICAÇÃO DOS GÊNEROS ENCONTRADOS}

1. Células com sistemas de hastes mucilaginosas Snowella

1. Células sem sistema de hastes mucilaginosas 2

2. Células ovais Coelomoron

2. Células esféricas ou hemisféricas Coelosphaerium

\section{Coelomoron Buell, 1938.}

Espécie-tipo: Coelomoron regularis Buell, Bull. Torrey bot. Cl., v. 65, p. 379. 1938.

O gênero Coelomoron foi descrito a partir de material proveniente de um lago nos Estados Unidos por Buell (1938) e caracteriza-se por apresentar colônias microscópicas, esféricas, elípticas ou ovais que, quando adultas, são ocas; mucilagem incolor e difluente; do centro das colônias jovens partem hastes mucilaginosas que desaparecem ao longo do tempo; células levemente alongadas que se dispõem esparsa e aleatoriamente nas colônias jovens e radialmente nas colônias bem desenvolvidas; as células se dividem em dois planos em sucessivas gerações e a reprodução ocorre através da desintegração da colônia (BUELL, 1938; KOMÁREK \& ANAGNOSTIDIS, 1998).

Coelosphaerium Nägeli é o gênero mais próximo de Coelomoron e difere deste pela forma e disposição das células na colônia.

Segundo Komárek \& Anagnostidis (1998), Coelomoron pertence à subfamília Gomphosphaerioidea (Merismopediaceae), no entanto, no sistema de classificação de Hoffmann et al. (2005), o gênero ainda pertencente a Merismopdiaceae, mas um gênero à parte de Gomphosphaerioidea, e esta foi elevada à categoria de família da subclasse Oscillatoriophycideae.

Coelomoron trata-se de um gênero com seis espécies descritas e com ampla distribuição, ocorrendo tanto em zonas temperadas como tropicais (KOMÁREK \& HAEUR, 2009). 
Coelomoron pusillum (Van Goor) Komárek et Hindák, Algolog. Stud., v. 50-53, p. 210. 1988. Basônimo: Coelosphaerium pusillum Van Goor, Rec. trav. Bot. Néerl, 21, p. 318. 1924.

(Figs. 7A, 11B)

Colônias microscópicas, esféricas ou levemente ovais, 14,5-18,8 $\mu \mathrm{m}$ diâm., com poucas células (10-24 células) dispostas mais ou menos radialmente na periferia da colônia; mucilagem homogênea, discreta, incolor, margem difluente; células ovais, 2,2-4,0 $\mu$ m diâm., 3,2-4,5 $\mu$ m compr.; conteúdo celular verde-azulado, homogêneo; sem aerótopos.

Coelomoron pusillum foi descrita originalmente dentro do gênero Coelosphaerium, caracterizado pela ausência de um sistema de hastes mucilaginosas e por apresentar células esféricas, no entanto, Komárek \& Hindák (1988) transferiram a espécie baseados na forma celular.

Os espécimes observados estão de acordo com a literatura especializada (GEITLER, 1932; KOMÁREK \& ANAGNOSTIDIS, 1998). C. pusillum é uma espécie amplamente distribuída. No Brasil, quatro das seis espécies de Coelomoron já foram documentadas. Dentre elas, C. tropicale Senna, Peres et Komárek e C. microcystoides Komárek são as espécies que mais se assemelham, diferindo basicamente, pelas dimensões de suas colônias e distribuição das células nas mesmas.

Em relação às dimensões das colônias, $C$. microcystoides apresenta os maiores valores, enquando $C$. pusillum e $C$. tropicale apresentam dimensões parecidas, podendo $C$. pusillum exibir colônias levemente maiores (SENNA et al., 1998). Quanto ao diâmetro celular, C. pusillum e C. tropicale possuem valores que se sobrepõem e a característica utilizada para separação das duas espécies é a distribuição das células na colônia, onde os espécimes observados apresentaram células levemente distantes umas das outras, como referido para C. pusillum.

No presente trabalho, os espécimes identificados como $C$. pusillum estiveram presente apenas no plâncton da Lagoa dos Gateados.

Material examinado: HAS 104171. 
Tabela 8: Comparação entre Coelomoron pusillum Senna et al. e espécies próximas.

\begin{tabular}{|c|c|c|c|}
\hline & C. microcystoides & C. tropicale & C. pusillum \\
\hline Colônias & microscópicas & microscópicas & microscópicas \\
\hline Forma & $\begin{array}{l}\text { esféricas com contorno } \\
\text { irregular }\end{array}$ & $\begin{array}{l}\text { esféricas a um pouco } \\
\text { alongadas }\end{array}$ & $\begin{array}{l}\text { esféricas a um pouco } \\
\text { alongadas }\end{array}$ \\
\hline $\begin{array}{l}\text { Dimensões ( } \mu \mathrm{m} \\
\text { diâm.) }\end{array}$ & $-50(80)$ & $(9,8) 10,7-13,7(16,8)$ & $14,5-18,8$ \\
\hline $\begin{array}{l}\text { Disposição das células } \\
\text { na mucilagem }\end{array}$ & $\begin{array}{l} \pm \text { densamente e } \\
\text { radialmente organizadas }\end{array}$ & $\begin{array}{l}\text { densamente e radialmente } \\
\text { organizadas }\end{array}$ & $\begin{array}{l}\text { levemente distantes } \\
\text { umas das outras e } \\
\text { radialmente } \\
\text { organizadas }\end{array}$ \\
\hline Mucilagem & $\begin{array}{l}\text { estreita, discreta e } \\
\text { incolor }\end{array}$ & estreita, discreta e incolor & discreta e incolor \\
\hline \multicolumn{4}{|l|}{ Células } \\
\hline Forma & $\begin{array}{l}\text { oval ou triangular } \\
\text { arredondada }\end{array}$ & $\begin{array}{l}\text { oval ou triangular } \\
\text { arredondada }\end{array}$ & $\begin{array}{l}\text { oval ou triangular } \\
\text { arredondada }\end{array}$ \\
\hline Dimensões $(\mu \mathrm{m})$ & $1,6-3,6 \times 0,9-3,0$ & $\begin{array}{l}(1,8) 2,8-3,0 \times \\
(1,4) 2,3-2,8(-3,0)\end{array}$ & $2,2-4,0 \times 3,2-4,5$ \\
\hline Conteúdo celular & $\begin{array}{l}\text { verde-azulado, } \\
\text { homogêneo }\end{array}$ & $\begin{array}{l}\text { verde-azulado, } \\
\text { homogêneo }\end{array}$ & $\begin{array}{l}\text { verde-azulado, } \\
\text { homogêneo }\end{array}$ \\
\hline Hábitat & metafíton & plâncton e metafíton & plâncton \\
\hline
\end{tabular}

\section{Coelosphaerium Nägeli, 1849.}

Espécie-tipo: Coelosphaerium kuetzingianum Nägeli, Neue Denkschr. Allg., v. 10, n. 7, p. 54. 1949.

O gênero Coelosphaerium compreende principalmente espécies planctônicas, com ampla distribuição, ocorrendo tanto em zonas temperadas como em zonas tropicais.

Segundo Komárek \& Anagnostidis (1998), o gênero Coelosphaerium caracteriza-se pelas colônias microscópicas, esféricas ou ovais, às vezes compostas por subcolônias envolvidas por uma mucilagem incolor; as células são esféricas ou hemisféricas após a divisão e estão dispostas na periferia da colônia; o conteúdo celular é homogêneo ou granuloso e uma espécie apresenta aerótopos; a divisão celular ocorre em dois planos em sucessivas gerações e a reprodução se dá através da fragmentação da colônia.

Coelosphaerium apresenta características muito semelhantes aos gêneros Woronichinia Elenkin, Snowella Elenkin e Gomphosphaeria Kützing, pois todos apresentam células dispostas radialmente na superfície da colônia e que se dividem em dois planos em sucessivas gerações. Estes gêneros diferem principalmente pela estrutura da mucilagem, que é homogênea em Coelosphaerium e forma um sistema de talos nos demais gêneros. 
Morfologicamente, Coelomoron constitui-se no gênero mais próximo de Coelosphaerium, ambos apresentam células dispostas na periferia da colônia e mucilagem homogênea.

Segundo Komárek \& Anagnostidis (1998), todos os gêneros citados acima pertencem à subfamília Gomphosphaerioideae, no entanto, Hoffmann et al. consideram Coelosphaerium e Coelomoron como pertencentes à Merismopediaceae e os demais táxons à Gomphosphaeriaceae.

Coelosphaerium kuetzingianum Nägeli, Gatt. Einzell. Alg., p. 54. 1849.

(Fig. 7C-D)

Colônias microscópicas, esféricas, 50,0-61,5 $\mu \mathrm{m}$ diâm.; células dispostas irregular e esparsamente, próximas da superfície da colônia; mucilagem homogênea, firme, incolor, margem difluente; células esféricas ou hemisféricas após a divisão, 2,3-2,9 $\mu \mathrm{m}$ diâm.; conteúdo celular verde-azulado, homogêneo ou granuloso; sem aerótopos.

As características morfológicas e métricas dos espécimes analisados estão de acordo com as apresentadas na literatura consultada (GEITLER, 1932; KOMÁREK \& ANAGNOSTIDIS, 1988).

Komárek \& Anagnostidis (1998) comentam que alguns espécimes de C. aerugineum Lemmermann foram erroneamente identificados como C. kuetzingianum por apresentarem características morfológicas e métricas similares. Embora as características morfológicas apresentadas pelas duas espécies sejam semelhantes, sua distribuição é um pouco diferente. $C$. aerugineum ocorre, principalmente, em regiões temperadas do Hemisfério Norte, enquanto $C$. kuetzingianum é possivelmente cosmopolita, ocorrendo frequentemente em países tropicais, sendo este o principal fator considerado na identificação da população observada.

No presente trabalho, C. kuetzingianum foi observada somente no plâncton, no banhado da Fazenda Rincão do Anastácio e constitui o primeiro registro de sua ocorrência para o Rio Grande do Sul.

Material examinado: HAS 104202, HAS 104369. 
Tabela 9: Comparação entre Coelosphaerium kuetzingianum Senna et al. e sua espécie próxima.

\begin{tabular}{|c|c|c|}
\hline & C. aerugineum & C. kuetzingianum \\
\hline $\begin{array}{l}\text { Colônias } \\
\text { Forma }\end{array}$ & $\begin{array}{l}\text { esféricas, às vezes com 2-3 } \\
\text { subcolônias }\end{array}$ & esféricas \\
\hline Dimensões ( $\mu$ m diâm.) & -100 & $-61,5$ \\
\hline $\begin{array}{l}\text { Disposição das células } \\
\text { na mucilagem }\end{array}$ & $\begin{array}{l}\text { irregularmente e esparsamente } \\
\text { próximas } \\
\text { da superfície da colônia }\end{array}$ & $\begin{array}{l}\text { irregularmente e esparsamente } \\
\text { próximas } \\
\text { da superfície da colônia }\end{array}$ \\
\hline $\begin{array}{l}\text { Mucilagem } \\
\text { Contorno }\end{array}$ & $\begin{array}{l}\text { homogênea, firme, incolor } \\
\text { difluente }\end{array}$ & $\begin{array}{l}\text { homogênea, firme, incolor } \\
\text { difluente }\end{array}$ \\
\hline $\begin{array}{l}\text { Células } \\
\text { Dimensões }\end{array}$ & $2,5-4,0(5,5)$ & $2,3-2,9$ \\
\hline Conteúdo celular & verde-azulado, granuloso & $\begin{array}{l}\text { verde-azulado, levemente } \\
\text { granuloso }\end{array}$ \\
\hline Aerótopos & ausente & ausente \\
\hline Hábitat & principalmente plâncton & plâncton \\
\hline
\end{tabular}

\section{Snowella Elenkin, 1938.}

Espécie-tipo:Snowella rosea (Snow) Elenkin, Monogr. Algar.Cyanophic. Pars. Spec., n. 1, p. 278. 1938.

O gênero Snowella caracteriza-se por desenvolver colônias esféricas ou ovais, raramente compostas; envelope mucilaginoso indistinto ou distinto, homogêneo e incolor; hastes mucilaginosas radialmente organizadas no centro da colônia; células esféricas ou levemente alongadas, dispostas na periferia da colônia, nas extremidades das hastes mucilaginosas; divisão celular em dois planos em sucessivas gerações; reprodução através da desintegração da colônia ou, raramente, a partir de células solitárias.

Originalmente Snowella rosea foi descrita como Coelosphaerium por Snow (1903) e, posteriormente, Lemmermann (1907) classificou-a no gênero Gomphosphaeria Kützing, por apresentar hastes mucilaginosas no interior da colônia. Komárek \& Hindák (1988), classificaram Gomphosophaeria rosea como Snowella rosea baseados na morfologia das células e das hastes mucilaginosas que, em $S$. rosea, as células se separam rapidamente após a divisão e as hastes mucilaginosas são tênues, enquanto as espécies de Gomphosphaeria exibem células que permanecem unidas por algum tempo após a divisão, formando uma estrutura cordiforme, característica das espécies que compõem o gênero e hastes mucilaginosas espessas que chegam a envolver as células. 
Morfologicamente, o gênero Snowella se assemelha ao gênero Woronichinia Elekin, no entanto, este apresenta hastes mucilaginosas não ramificadas e Snowella, hastes que podem se ramificar.

Snowella é classificada dentro da família Merismopediaceae por Komárek \& Anagnostidis (1998), por apresentar divisão celular em dois planos. Entretanto, Hoffmann et al. (2005), classificam o gênero na família Microcystaceae (subclasse Oscillatoriophycidae), com base em estudos moleculares e ultraestruturais.

Snowella lacustris (Chodat) Komárek \& Hindák, Algolog. Stud., v. 50-53, p. 283-302. 1988.

Basônimo: Gomphosphaeria lacustris Chodat, Bull. Herb. Boissier v. 6, p. 180. 1898.

(Fig. 7E-F)

Colônias microscópicas, solitárias, esféricas, ovais ou irregulares, 22,0-45,0 $\mu \mathrm{m}$ diâm., 23,0-51,0 $\mu \mathrm{m}$ compr.; mucilagem homogênea, incolor, margem difluente; sistema de hastes mucilaginosas; células obovóides, 1,3-2,5 $\mu \mathrm{m}$ diâm., 2,0-3,2 $\mu \mathrm{m}$ compr.; conteúdo celular verde-azulado, homogêneo; sem aerótopos.

Os espécimes observados exibiram características que estão de acordo com as citadas para S. lacustris, no entanto, podiam ser confundidos com representantes do gênero Coelomoron, pois as hastes mucilaginosas apresentaram-se muito discretas, sendo difícil sua observação embora já tenham sido observadas algumas colônias jovens de Coelomoron com hastes mucilaginosas no centro.

Nos ambientes amostrados, S. lacustris foi observado apenas no plâncton.

Material examinado: HAS 104103, HAS 104163, HAS 104348, HAS 104351, HAS 104352.

\section{CHAMAESIPHONACEAE Borzi, 1882.}

A família é sustentada apenas por caracteres morfológicos, incluindo dados ultraestruturais (HOFFMANN et al., 2005) e caracteriza-se pelas células sésseis, heteropolares, solitárias ou em grupos; as células são envoltas por uma bainha firme, incolor e homogênea; a divisão celular é assimétrica, em um plano perpendicular ao maior eixo celular ou em mais direções na porção apical da célula, e em pseudofilamentos, apenas a célula terminal tem habilidade de se dividir, formando exocitos, que se separam da célula mãe e germinam originando um novo indivíduo. 
A classificação proposta por Hoffmann et al. (2005), para cianobactérias apresenta algumas alterações em relação à apresentada por Komárek \& Anagnostidis (1998). Segundo os últimos autores, Chamaesiphonaceae é composta por seis gêneros, Chamaecalyx Komárek et Anagnostidis, Chamaesiphon Braun et Grunow, Clastidium Kirchner, Cyanophanon Geitler, Geitleribactron Komárek e Stichosiphon Geitler, que apresentam hábito e reprodução semelhantes. No entanto, segundo Hoffmann et al. (2005), a família compreende quatro gêneros, Chamaesiphon, Clastidium, Cyanophanon e Geitleribactron. De acordo com esses autores, os gêneros Chamaecalyx e Stichosiphon e as espécies pertencentes a Chamaesiphon subgênero Godlewskia pertencem a Stichosiphonaceae, em Oscillatoriophycideae. A separação desses gêneros para Stichosiphonaceae baseia-se na observação de caracteres morfológicos, incluindo dados de ultraestrutura. A separação das espécies de Chamaesiphon em famílias diferentes mostra a necessidade da classificação das espécies pertencentes ao subgênero Godlewskia em um novo gênero.

A posição dos gêneros de Chamaesiphonaceae é sustentada por caracteres morfológicos e somente Chamaesiphon subgênero Chamaesiphon possui suporte molecular, no entanto, sem análise da espécie-tipo (HOFFMANN et al., 2005).

Nos ambientes amostrados foi registrada a ocorrência de apenas uma espécie da família, Chamaesiphon amethystinus (Rostafinski) Lemmermann.

\section{Chamaesiphon Braun et Grunow, 1865}

Espécie-tipo: Chamaesiphon confervicola Braun In Rabenhorst, Algen. Eur. Decaden, v. 72/73. 1865.

Chamaesiphon é um gênero caracterizado por apresentar células heteropolares, leve ou distintamente alongadas, aderidas a um substrato, podendo este ser rochas ou plantas; seus representantes variam de células solitárias a colônias micro ou macroscópicas; as células podem ser esféricas, cilíndricas, ovais ou elípticas, sempre circundadas por uma bainha que pode ser lamelada ou não; a divisão celular é sempre assimétrica, próxima ao ápice celular e as células-filhas são liberadas através da bainha mucilaginosa aberta ou envoltas por uma porção da bainha ou ainda, permanecem unidas à mucilagem colonial; a reprodução se dá através da liberação da célula filha na célula-mãe ou da colônia.

Segundo Komárek \& Hauer (2009), as espécies de água doce são encontradas aderidas em plantas aquáticas, algas ou rochas, conferindo, às vezes, manchas amareladas ou castanhas/marrons. Uma espécie é conhecida por ser epizoica em crustáceos. 
Algumas espécies apresentam distribuição geográfica limitada, sendo características de comunidades perifíticas, no entanto, o gênero tem ampla distribuição ao redor do mundo.

Segundo Komárek \& Anagnostidis (1998), o gênero é composto por dois subgêneros, Chamaesiphon e Godlewskia, que foram organizados em subclasses diferentes no sistema de classificação de Cyanobacteria proposto por Hoffmann et al. (2005): Chamaesiphon em Synechococcophycidae e Godlewskia em Oscillatoriophycidae.

No presente estudo foi documentada a ocorrência de apenas uma espécie de Chamaesiphon, pertencente ao subgênero Chamaesiphon (KOMÁREK \& ANAGNOSTIDOS, 1998).

Chamaesiophon amethystinus (Rostafinski) Lemmermann, Krypt. Fl. Mark Brandenb., 3, p. 99. 1910.

Basônimo: Sphaerogonium amethystinum Rostafinski, R. Ak. Um. Kraków, 10, p. 291. 1883.

(Figs. 7B, 11F-G)

Células solitárias ou grupos de células arranjadas paralelamente, aderidas individualmente ao substrato; bainha homogênea, firme, incolor; células cilíndricas com a extremidade apical arredondada e a base atenuada, 3,0-4,5 $\mu \mathrm{m}$ diâm., 6,4-18,5 $\mu \mathrm{m}$ compr., com um disco mucilaginoso na base que auxilia na fixação; conteúdo celular verde-azulado, homogêneo; sem aerótopos.

Os espécimes analisados diferem do registrado por Geitler (1932) por apresentarem células com diâmetro menor que o mencionado por esse autor $(4,0-6,5 \mu \mathrm{m})$. Contudo, os limites métricos registrados para a população observada estão de acordo com os valores métricos citados por Komárek \& Anagnostidis (1998).

A população analisada apresentou características métricas semelhantes às de $C$. incrustans Grunow (KOMÁREK \& ANAGNOSTIDIS, 1998), no entanto os espécimes apresentaram um disco mucilaginoso que auxilia na adesão do indivíduo ao substrato, características não observadas em $C$. incrustans.

Assim como Gold-Morgan et al. (1996), a população observada raramente apresentou exocitos e, quando estes estavam presentes, eram únicos e esféricos. Todos os espécimes registrados foram encontrados como epífitos de diatomáceas.

O presente trabalho relata a primeira ocorrência da espécie para o Rio Grande do Sul. Material examinado: HAS 104171. 


\section{PSEUDANABAENALES}

A ordem Pseudanabaenales é formada pelas cianobactérias filamentosas que apresentam tilacoides parietais. Os representantes da ordem apresentam células com organização unisseriada, formando tricomas, que não apresentam células diferenciadas, não formam ramificações verdadeiras e podem estar envolvidos por bainha mucilaginosa. $\mathrm{O}$ conjunto formado por tricoma e bainha mucilaginosa é denominado filamento e este pode conter um ou mais tricomas.

Nos sistemas de classificação propostos anteriormente, as cianobactérias que constituem a ordem Pseudanabaenales, pertencem a outra ordem e outras famílias. Segundo Gomont (1892), as cianobactérias filamentosas homocitadas estão classificadas na família Hormogonae, subfamília Homocysteae, que compreende 15 gêneros divididos em duas tribos. A divisão das tribos, Vaginariae e Lyngbyaea, basea-se no tipo de bainha mucilaginosa e no número de tricomas por bainha, onde a primeira é composta pelas cianobactérias cujos filamentos possuem bainha mucilaginosa colorida e esta engloba mais de um tricoma e a segunda, pelas espécies que exibem tricomas com ou sem bainha mucilaginosa, simples ou com ramificações falsas. Geitler (1932) organizou as formas filamentosas homocitadas na família Oscillatoriaceae, baseado em características morfológicas e métricas dos tricomas e filamentos e no hábitat.

Posteriormente, Anagnotidis \& Komárek (1988) organizaram as cianobactérias que compõem Pseudanabaenales em três famílias na ordem Oscillatoriales: Pseudanabaenaceae, Schizotrichaceae e Phormidiaceae. A divisão das famílias era baseada em características como tipo de talo, tipo de tricoma, fragmentação, mobilidade, tipo de bainha mucilaginosa, número de tricomas por bainha, aerótopos, morfologia da célula apical.

Em 2005, Jiri Komárek e Konstantinus Anagnostidis organizaram as cianobactérias da ordem Pseudanabaenales nas famílias Pseudanabaenaceae (caracterizada por desenvolver tricomas cilíndricos, solitários ou em feixes, com até $3 \mu \mathrm{m}$ diâm., com ou sem bainha mucilaginosa e células mais longas que largas) e Schizotrichaceae (caracterizada por apresentar bainha mucilaginosa espessa, obrigatoriamente fechadas nas extremidades e envolvendo mais de um tricoma).

Segundo Hoffmann et al. (2005), as cianobatérias que compõem a ordem Pseudanabaenales são classificadas em duas famílias: Pseudanabaenaceae e Schizotrichaceae. 
No presente estudo, apenas Pseudanabaenaceae representa a ordem Pseudanabaenales com registro de 9 espécies.

\section{PSEUDANABAENACEAE Anagnostidis et Komárek, 1988.}

A família Pseudanabaenaceae é caracterizada por desenvolver tricomas cilíndricos, unisseriados, móveis ou imóveis, com ou sem bainha mucilaginosa incolor e homogênea; filamentos, retos, flexuosos ou mais ou menos regularmente espiralados, solitários, em feixes ou formando tufos, células geralmente mais longas que largas ou, menos frequentemente, isodiamétricas ou mais curtas que largas, todas capazes de se dividir; aerótopos ausentes ou localizados (centrais ou terminais); reprodução através da fragmentação do tricoma sem formação de necrídios, formando hormogônios ou hormocitos (KOMÁREK \& ANAGNOSTIDIS, 2005).

Segundo Komárek \& Anagnostidis (1988), a família Pseudanabaenaceae está organizada em 10 gêneros, divididos em três subfamílias: Pseudanabaenoideae (Pseudanabaena, Geitlerinema e Romeria), Limnotrichoideae (Arthronema, Jaaginema, Limnothrix e Palikiella) e Leptolyngbyoideae (Leibleinia, Leptolyngbya e Planktolyngbya).

Komárek \& Anagnostidis (2005) incluíram na família 16 gêneros organizados em quatro subfamílias: Pseudanabaenoideae (Arthronema, Geitlerinema, Halomicronema, Jaaginema, Limnothrix, Pseudanabaena e Romeria), Spirulinoideae (Glaucospira, Halospirulina e Spirulina), Leptolyngbyoideae (Leibleinia, Leptolyngbya e Planktolyngbya) e Heteroleibleinioideae (Heteroleibleinia, Sokolovia e Tapinothrix). Mais recentemente Hoffmann et al. (2005) organizaram a família em 15 gêneros, onde Prochlorothrix BurgerWiersma, tradicionalmente conhecida como proclorófita e Spirocoleus (Möbius et Kirchner) Crow foram incluídos na família e os gêneros Glaucospira, Halospirulina e Spirulina foram reorganizados e classificadas na família Spirulinaceae (sublcasse Oscillatoriophycidae).

Foram registradas, no presente estudo, nove espécies pertencentes a três subfamílias: Pseudanabaenoideae (Geitlerinema [2] e Pseudanabaena [1]), Spirulinoideae (Spirulina [1]), Leptolyngbyoideae (Leptolyngbya [3] e Planktolyngbya [2]). 


\section{CHAVE PARA IDENTIFICAÇÃO DAS SUBFAMÍLIAS ENCONTRADAS}

1. Tricomas com bainha mucilaginosa Leptolyngbyoideae

1. Tricomas sem bainha mucilaginosa 2

2. Tricomas retos Pseudanabaenoideae

2. Tricomas espiralados Spirulinoideae

Subfamília Pseudanabaenoideae (Elenkin) Komárek et Anagnostidis, 1986.

\section{CHAVE PARA IDENTIFICAÇÃO DOS GÊNEROS ENCONTRADOS}

1. Tricomas com crescimento limitado, distintamente constrito Pseudanabaena

1. Tricomas longos, não constritos ou levemente constritos Geitlerinema

\section{Geitlerinema (Anagnostidis et Komárek) Anagnostidis, 1989.}

Espécie-tipo: Geitlerinema splendidum (Greville ex Gomont) Anagnostidis, Pl. Syst. Evol., 164, p. 35. 1989.

A espécie-tipo de Geitlerinema foi originalmente descrita como Phormodium splendidum Kützing ex Gomont e incluída no subgênero Geitlerinema por Anagnostidis \& Komárek (1988). No entanto, Anagnostidis (1989) elevou Geitlerinema ao nível de gênero baseado no fato de que este não possui a capacidade de formar bainha mucilaginosa como Phormidium e compartilha características morfológicas que o aproximam dos representantes de Pseudanabaenaceae.

O gênero Geitlerinema é caracterizado por desenvolver talos delgados, delicados, verde-azulados, castanhos ou violetas, às vezes formando fascículos; ocasionalmente tricomas solitários, cilíndricos, retos, levemente flexuosos ou raramente espiralados, não constritos a levemente constritos, gradualmente atenuados e curvos ou espiralados no ápice, raramente não atenuados e retos; células mais longas que largas, normalmente com grânulos de cianoficina ou corpúsculos de carotenoides; sem aerótopos; células apicais normalmente cônicas, curvas, frequentemente acuminadas ou arredondadas, raramente capitadas, retas ou cilíndrico-arredondadas; reprodução pela liberação de hormogônios, sem formação de necrídios.

Geitlerinema amphibium e G. splendidum foram os representantes registrados nos ecossistemas associados. 


\section{Chave para identificação das espécies encontradas}

1. Tricomas com células apicais não capitadas G. amphibium

1. Tricomas com células apicais capitadas G. splendidum

Geitlerinema amphibium (Agardh ex Gomont) Anagnostidis, Pl. Syst. Evol. 164, p. 35, 37. 1989.

Basônimo: Oscillatoria amphibia Agardh ex Gomont, Ann. Sci. nat. Sér, 7, v. 16, p. 221. 1892.

(Figs. 8B, 12A)

Tricomas solitários, retos ou flexuosos, não constritos, não atenuados a levemente atenuados, 1,6-2,8 $\mu \mathrm{m}$ diâm.; células 1,5-2,9 vezes mais longas que largas, 2,0-5,5 $\mu \mathrm{m}$ compr.; conteúdo celular verde-azulado, homogêneo, sem aerótopos, septos granulosos (1-2 grânulos) e translúcidos; células apicais cilíndrico-arredondadas, sem espessamento.

Geitlerinema amphibium e G. unigranulatum (R. N. Singh) Komárek et Azevedo são espécies que apresentam características morfológicas e métricas semelhantes, podendo gerar problemas de identificação. Ambas apresentam dimensões celulares que se sobrepõem (KOMÁREK \& ANAGNOSTIDIS, 2005), no entanto, Komárek \& Azevedo (2000), baseados em estudos com populações paulistas, afirmam que as duas espécies podem ser diferenciadas pelo aspecto dos septos, que são translúcidos em $G$ amphibium e indistintos em $G$. unigranulatum.

A partir dessas considerações, os espécimes observados, mesmo os que apresentaram apenas um grânulo por septo, foram identificados como G. amphibium, pois todos eles apresentaram paredes transversais translúcidas, além das características métricas referidas para a espécie.

No ecossistema estudado G. amphibium ocorreu tanto no plâncton quanto no metafíton.

Material examinado: HAS 104167, HAS 104171, HAS 104213, HAS 104352, HAS 104356, HAS 104366, HAS 104391, HAS 104427, HAS 104455. 
Geitlerinema splendidum (Greville ex Gomont) Anagnostidis, Pl. Syst. Evol. 164, p. 35. 1989.

Basônimo: Oscillatoria splendida Greville ex Gomont, Ann. Sci. nat. Sér, 7, v. 16, p. 224. 1892.

(Figs. 8A, 12B-C)

Tricomas solitários, retos ou flexuosos, não constritos, atenuados, curvos no ápice, 2,2-3,0 $\mu \mathrm{m}$ diâm.; células 1,3-2,9 vezes mais longas que largas, 3,7-6,5 $\mu \mathrm{m}$ compr.; conteúdo celular verde-azulado, homogêneo, sem aerótopos, septos granulosos (1-2 grânulos) e translúcidos; células apicais alongadas e capitadas, sem espessamento.

Geitlerinema splendidum é uma espécie amplamente distribuída e conhecida. A morfologia da célula apical constitui a principal característica que a distingue das demais espécies do gênero (alongada, curva e capitada).

Dessa forma, os espécimes analisados possuem características morfológicas e métricas que estão de acordo com as referidas para G. splendidum na literatura consultada (KOMÁREK \& ANAGNOSTIDIS, 2005).

Geitlerinema splendidum foi registrada tanto no plâncton quanto no metafíton.

Material examinado: HAS 104092, HAS 104112, HAS 104117, HAS 104131, HAS 104163, HAS 104167, HAS 104171, HAS 104174, HAS 104179, HAS 104180, HAS 104193, HAS 104202, HAS 104223, HAS 104240, HAS 104242, HAS 104339, HAS 104340, HAS 104362 , HAS 104369, HAS 104386, HAS 104391, HAS 104394, HAS 104399, HAS 104427.

Tabela 10: Principais características comparativas entre as espécies de Geitlerinema documentadas no presente trabalho.

\begin{tabular}{lll}
\hline Tricomas & G. amphibium & G. splendidum \\
& $\begin{array}{l}\text { solitários, retos ou flexuosos, não } \\
\text { constrito, não atenuados a } \\
\text { levemente atenuados }\end{array}$ & $\begin{array}{l}\text { solitários, retos ou flexuosos, } \\
\text { não constrito, atenuados, curvos } \\
\text { no ápice }\end{array}$ \\
$\begin{array}{l}\text { Diâmetro }(\mu \mathrm{m}) \\
\text { Células }\end{array}$ & $1,6-2,8$ & $2,2-3,0$ \\
Comprimento $(\mu \mathrm{m})$ & $2,0-5,5$ & $3,7-6,5$ \\
RC/L & $1,5-2,9$ & $1,3-2,9$ \\
Conteúdo celular & verde-azulado, homogêneo & verde-azulado, homogêneo \\
Septos & granulosos e translúcidos & granulosos e translúcidos \\
Hábitat & plâncton e metafíton & plâncton e metafíton \\
\hline
\end{tabular}




\section{Pseudanabaena Lauterborn, 1915.}

Espécie-tipo: Pseudanabaena catenata Lauterborn, Verh. naturh.-med. Ver. Heidelb., v.13, n. 2, p. 437.1916.

Pseudanabanea é um gênero que engloba espécies que podem ser encontradas principalmente no plâncton, no metafíton e no bentos. Poucas espécies podem ser observadas em mucilagens de outras algas, no solo ou em ambientes extremos.

O gênero caracteriza-se por apresentar tricomas solitários ou formando tufos, sem bainha mucilaginosa; células cilíndricas com extremidades arredondadas, mais longas que largas ou raramente isodiamétricas; células apicais não diferenciadas, cilíndrico-arredondadas, cilíndrico-cônicas ou cônico-agudas, sem caliptra ou espessamento; sem aerótopos (KOMÁREK \& ANAGNOSTIDIS, 2005).

No presente trabalho foi registrada apenas uma espécie do gênero, Pseudanabaena catenata.

Pseudanabaena catenata Lauterborn, Verh. naturh.-med. Ver. Heidelb., v. 13, n.2, p.437. 1916.

(Figs. 8C, 12D)

Tricomas solitários, retos ou flexuosos, não atenuados, constritos, 1,6-2,4 $\mu \mathrm{m}$ diâm.; células cilíndricas, 1,3-3,0 vezes mais longas que largas, 2,0-6,2 $\mu \mathrm{m}$ compr.; conteúdo celular verde-azulado, homogêneo, sem aerótopos, septos não granulosos; célula apical cilíndricoarredondada, sem espessamento.

Os espécimes analisados apresentaram características morfológicas e métricas que estão de acordo com as citadas por Anagnostidis \& Komárek (2005), contudo, deve-se comentar sobre o diâmetro celular que, nas populações observadas, foram registradas células mais largas $(2,4 \mu \mathrm{m})$, ultrapassando o limite métrico máximo $[2,0(2,2) \mu \mathrm{m}]$ referido para a espécie.

Apesar disso, os espécimes analisados foram identificados como P. catenata por exibirem as demais características referidas para a espécie na literatura consultada.

Pseudanabaena catenata foi registrada no presente estudo ocorrendo tanto no plâncton quanto no metafíton, fato também observado por Werner (2002), apesar de ser conhecida por ocorrer no plâncton (DESIKACHARY, 1959; SENNA, 1992; WERNER \& ROSA, 1992).

Material examinado: HAS 104125, HAS 104134, HAS 104171, HAS 104174, HAS 104202, HAS 104209, HAS 104242, HAS 104340, HAS 104427, HAS 104442, HAS 104455. 
Subfamília Leptolyngbyoideae Anagnostidis et Komárek, 1989.

\section{CHAVE PARA IDENTIFICAÇÃO DOS GÊNEROS ENCONTRADOS}

1. Filamentos solitários ou emaranhados, metafíticos Leptolyngbya

1. Filamentos solitários, planctônicos Planktolyngbya

\section{Leptolyngbya Anagnostidis et Komárek, 1988.}

Espécie-tipo: Leptolyngbya boryana (Gomont) Anagnostidis et Komárek, Algolog. Stud., v. 50-53, p. 391. 1988.

Leptolyngbya é um gênero que engloba um grande número de espécies. Trata-se de um grupo natural que abrange várias espécies originalmente descritas em outros gêneros como Lyngbya, Phormidium e Plectonema (KOMÁREK \& ANAGNOSTIDIS, 2005). Segundo Komárek (2007), várias espécies do gênero constituem as principais cianobactérias de muitos ecossistemas em todo o mundo, de forma que muitos morfotipos ocorrem em quase todos os habitats, incluindo ambientes extremos.

O gênero apresenta morfologia simples, fato que dificulta a taxonomia dentro do grupo. Segundo Komárek \& Anagnostidis (2005), Leptolyngbya se caracteriza por desenvolver filamentos emaranhados ou solitários, flexuosos, espiralados ou raramente retos, longos; bainha mucilaginosa incolor, firme; tricomas 0,5-3,5 $\mu \mathrm{m}$ diâm., não atenuados, não capitados; células cilíndricas, isodiamétricas, ou mais longas ou mais curtas, usualmente com cromatoplasma e centroplasma evidentes; sem aerótopos; reprodução através da fragmentação do tricoma, com ou sem a formação de necrídios.

No presente estudo foram registradas três espécies representando Leptolyngbya.

\section{Chave para identificação das espécies encontradas}

1. Filamentos emaranhados L. cebennensis

1. Filamentos solitários

2. Filamentos retos ou flexuosos, tricomas 1,0-1,5 $\mu \mathrm{m}$ diâm. L. perelegans

2. Filamentos flexuosos ou espiralados, tricomas 1,5-2,0 $\mu \mathrm{m}$ diâm. L. lagerheimii 
Leptolyngbya cebennensis (Gomont) Umezaki et M. Watanabe, Jap. J. Phycol. 42, p. 203. 1994.

Basônimo: Phormidium cebennensis Gomont, Bull. Soc. Bot. Fr. 46, p. 38. 1899.

(Figs. 8F, 12E)

Filamentos emaranhados ou solitários, retos ou flexuosos, 2,5-3,5 $\mu \mathrm{m}$ diâm.; bainha mucilaginosa fina, homogênea, incolor; tricomas não atenuados, não constritos a levemente constritos, 1,8-2,5 $\mu \mathrm{m}$ diâm.; células 0,7-1,2 vezes mais longas que largas, 1,0-2,5 $\mu \mathrm{m}$ compr.; conteúdo celular verde-azulado, homogêneo, sem aerótopos; septos translúcidos, sem grânulos; célula apical cilíndrico-arredondada, sem espessamento.

Os espécimes analisados apresentaram características morfológicas e métricas que estão de acordo com os referidos para a espécie por Komárek \& Anagnostidis (2005). Entretanto, os exemplares estudados por Desikachary (1959) apresentaram diâmetros celulares inferiores ( até 2,0 $\mu \mathrm{m}$ )

Essa espécie é conhecida por formar talos que ocorrem em ambientes subaéreos ou aderidos em rochas submersas (DESIKACHARY, 1959; KOMÁREK \& ANAGNOSTIDIS, 2005), no entanto, as populações observadas no presente estudo estavam presentes no metafíton.

Dessa forma, os espécimes observados foram identificados como L. cebennensis baseado nas características morfológicas e métricas, e no fato de que os filamentos apresentavam-se em grandes emaranhados e foram encontrados em lagoas rasas, com grande quantidade de vegetação e sujeitas à ação dos ventos, que poderia ter causado a remoção desses organismos para a superfície da água.

O registro da espécie no presente trabalho trata-se da primeira citação para o Rio Grande do Sul.

Material examinado: HAS 104142, HAS 104171, HAS 104356, HAS 104360, HAS 104427.

Leptolyngbya lagerheimii (Gomont) Anagnostidis et Komárek, Algolog. Stud., v. 50-53, p. 391. 1988.

Basônimo: Lyngbya lagerheimii Gomont, Ann. Sci. nat. Sér. 7, v. 16, p. 147. 1892.

(Figs. 8D, 12F)

Filamentos solitários, frouxamente espiralados ou raramente flexuosos, 1,5-2,5 $\mu \mathrm{m}$ diâm.; bainha mucilaginosa fina, homogênea, incolor; tricomas não atenuados, não constritos, 1,5-2,0 $\mu \mathrm{m}$ diâm.; células $0,9-1,5$ vez mais longas que largas, 1,5-2,5 $\mu \mathrm{m}$ compr.; conteúdo 
celular verde-azulado, homogêneo, sem aerótopos; septos espessos, sem ou com um único grânulo; célula apical cilíndrico-arredondada, sem espessamento.

A população observada apresentou filamentos com espiras regulares, raramente com espiras irregulares ou filamentos retos ou flexuosos. Grande parte dos espécimes apresentou septo espesso e translúcido com um único grânulo. Além dessas características, as dimensões observadas estão de acordo com Gomont (1892).

Leptolyngbya lagerheimii foi observada somente no metafíton da lagoa dos Gateados. Material examinado: HAS 104134.

Leptolyngbya perelegans (Lemmermann) Anagnostidis et Komárek, Algolog. Stud., v. 50-53, p. 392.1988.

Basônimo: Lyngbya perelegans Lemmermann, Abh. Naturw. Ver. Bremen, v. 16, p. 355. 1899.

Filamentos solitários, retos ou flexuosos, 1,5-2,2 $\mu \mathrm{m}$ diâm.; bainha mucilaginosa fina, homogênea, incolor; tricomas não atenuados, não constritos a levemente constritos, 1,0-1,5 $\mu \mathrm{m}$ diâm.; células 1,4-3,5 vezes mais longas que largas, 1,8-4,5 $\mu$ m compr.; conteúdo celular verde-azulado, homogêneo, sem aerótopos; septos usualmente com um ou dois grânulos de cada lado; célula apical cilíndrico-arredondada, sem espessamento.

Os espécimes analisados possuem as características morfológicas e métricas que correspondem às de Leptolyngbya perelegans (FRÉMY, 1930; GEITLER, 1932; KOMÁREK \& ANAGNOSTIDIS, 2005).

Apesar de a espécie ser conhecida para o perifíton ou para o bentos, os espécimes foram registrados no metafíton da lagoa do Capivari.

Material examinado: HAS 104098. 
Tabela 11: Principais características comparativas entre as espécies de Leptolyngbya documentadas no presente trabalho.

\begin{tabular}{|c|c|c|c|}
\hline & L. cebennensis & L. lagerheimii & L. perelegans \\
\hline Filamentos & $\begin{array}{l}\text { emaranhados ou } \\
\text { solitários, retos ou } \\
\text { flexuosos }\end{array}$ & $\begin{array}{l}\text { solitários, retos, } \\
\text { flexuosos ou espiralados }\end{array}$ & $\begin{array}{l}\text { solitários, retos ou } \\
\text { flexuosos }\end{array}$ \\
\hline Bainha mucilaginosa & homogênea, & homogênea, & homogênea, \\
\hline Diâmetro( $\mu \mathrm{m})$ & $2,5-3,5$ & $1,5-2,5$ & $1,5-2,2$ \\
\hline Tricomas & $\begin{array}{l}\text { não atenuados, } \\
\text { não constritos a } \\
\text { levemente constritos }\end{array}$ & $\begin{array}{l}\text { não atenuados, } \\
\text { não constritos }\end{array}$ & $\begin{array}{l}\text { não atenuados, } \\
\text { não constritos a } \\
\text { levemente constritos }\end{array}$ \\
\hline Diâmetro $(\mu \mathrm{m})$ & $1,8-2,5$ & $1,5-2,0$ & $1,0-1,6$ \\
\hline $\begin{array}{l}\text { Células } \\
\text { Comprimento }(\mu \mathrm{m})\end{array}$ & $1,0-2,5$ & $1,5-2,5$ & $1,8-4,5$ \\
\hline $\mathrm{RC} / \mathrm{L}$ & $0,7-1,2$ & $0,9-1,5$ & $1,4-3,5$ \\
\hline Conteúdo celular & $\begin{array}{l}\text { verde-azulado, } \\
\text { homogêneo }\end{array}$ & $\begin{array}{l}\text { verde-azulado, } \\
\text { homogêneo }\end{array}$ & $\begin{array}{l}\text { verde-azulado, } \\
\text { homogêneo }\end{array}$ \\
\hline Septos & $\begin{array}{l}\text { translúcidos, não } \\
\text { granuloso }\end{array}$ & $\begin{array}{l}\text { espessos, granuloso ou } \\
\text { não }\end{array}$ & granuloso \\
\hline Hábitat & metafíton & metafíton & metafíton \\
\hline
\end{tabular}

Planktolyngbya Anagnostidis et Komárek, 1988.

Espécie-tipo: Planktolyngbya limnetica (Lemmermann) Komárková-Legnerová et Cronberg, Algolog. Stud., v. 67, p. 21. 1992.

O gênero Planktolyngbya engloba algumas espécies que foram originalmente descritas dentro de Lyngbya subgênero Limneticae. Os representantes desse gênero são caracterizados por desenvolver filamentos solitários, retos, flexuosos, regular ou irregularmente espiralados; mucilagem firme e incolor; tricomas imóveis, cilíndricos, isopolares, unisseriados, não constritos a levemente constritos, não atenuados, não capitados; células cilíndricas, mais longas que largas ou raramente isodiamétricas; sem aerótopos; reprodução a partir da fragmentação do tricoma, sem formação de necrídios (KOMÁREK \& ANAGNOSTIDIS, 2005).

Segundo Komárek \& Kling (1991), as espécies de Planktolyngbya são planctônicas e muitas espécies são restritas apenas a regiões tropicais ou temperadas quentes, mas apresentam ampla distribuição. 
No presente estudo foram registradas duas espécies pertencentes ao gênero Planktolyngya.

\section{Chave para identificação das espécies encontradas}

1. Filamentos espiralados P. contorta

1. Filamentos retos. P. limnetica

Planktolyngbya contorta (Lemmermann) Anagnostidis et Komárek, Algolog. Stud., v. 50-53, p. 394. 1988.

Basônimo: Lyngbya contorta Lemmermann, ForschBer. Biol. Sta. Plön, v. 6, n. 2, p. 202. 1898.

(Figs. 8H, 12G)

Filamentos solitários, espiralados, 1,6-2,0 $\mu \mathrm{m}$ diâm.; bainha mucilaginosa fina, homogênea, incolor; tricomas não atenuados, não constritos, 1,3-1,7 $\mu \mathrm{m}$ diâm.; células 1,73,5 vezes mais longas que largas, 2,8-4,5 $\mu \mathrm{m}$ compr.; conteúdo celular verde-azulado, homogêneo, sem aerótopos; septos, às vezes, com um grânulo; célula apical cilíndricoarredondada, sem espessamento.

Planktolyngbya contorta é um componente comum no plâncton de lagos e constitui uma espécie com ampla distribuição. P. circumcreta (G. S. West) Anagnostidis et Komárek e $P$. regularis Komárková-Legnerová et Tavera podem ser confundidas com $P$. contorta por apresentarem características morfológicas e métricas semelhantes (KOMÁRKOVÁLEGNEROVÁ \& TAVERA, 1996; KOMÁREK \& ANAGNOSTIDIS, 2005; WERNER, 2002). Ambas as espécies apresentam filamentos espiralados e com diâmetros que se sobrepõem. No entanto, $P$. circumcreta pode ser diferenciada de $P$. contorta por apresentar células mais curtas $(1,0-2,0 \mu \mathrm{m})$.

A população analisada no presente estudo, embora tenha apresentado características métricas semelhantes às citadas para $P$. regularis (KOMÁRKOVÁ-LEGNEROVÁ \& TAVERA, 1996), foi identificada como $P$. contorta por apresentar filamentos irregularmente espiralados, enquanto $P$. regularis é caracterizada por apresentar tricomas com espiras regulares.

Nos ecossistemas estudados, $P$. contorta esteve presente no plâncton. 
Material examinado: HAS 104098, HAS 104103, HAS 104106, HAS 104112, HAS 104117, HAS 104132, HAS 104163, HAS 104167, HAS 104343, HAS 104348, HAS 104351, HAS 104352, HAS 104362, HAS 104366, HAS 104381, HAS 104391.

Planktolyngbya limnetica (Lemmermann) Komárková-Legnerová et Cronberg, Algolog. Stud., v. 67, p. 21, 22. 1992.

Basônimo: Lyngbya limnetica Lemmermann, ForschBer. Biol. Sta. Plön, v. 6, n. 2, p. 202. 1898.

(Figs. 8G, 12H)

Filamentos solitários, retos ou flexuosos, 1,0-2,0 $\mu \mathrm{m}$ diâm.; bainha mucilaginosa fina, homogênea, incolor; tricomas não atenuados, não constritos, 0,8-1,7 $\mu \mathrm{m}$ diâm.; células 1,65,0 vezes mais longas que largas, 3,0-5,0 $\mu \mathrm{m}$ compr.; conteúdo celular verde-azulado, homogêneo, sem aerótopos; septos, às vezes, com um grânulo; célula apical cilíndricoarredondada, sem espessamento.

Os espécimes analisados apresentaram características morfológicas que estão de acordo com as citadas para P. limnetica por Komárková-Legnerová \& Cronberg (1992).

Embora as autoras comentem que os septos dos tricomas de $P$. limnetica podem se apresentar indistintos, grande parte da população observada apresentou septos espessos e translúcidos, diferente do observado para populações de outros ecossistemas aquáticos do Rio Grande do Sul por Werner (2002). Além dos septos, os espécimes analisados apresentaram variação quanto à presença de grânulos nas paredes transversais dos tricomas.

A presença de $P$. limnetica foi registrada no plâncton dos ecossistemas estudados.

Material examinado: HAS 104098, HAS 104103, HAS 104106, HAS 104112, HAS 104117, HAS 104127, HAS 104131, HAS 104132, HAS 104142, HAS 104150, HAS 104163, HAS 104167, HAS 104174, HAS 104179, HAS 104180, HAS 104340, HAS 104343, HAS 104348, HAS 104350, HAS 104351, HAS 104352, HAS 104356, HAS 104362, HAS 104366, HAS 104376, HAS 104381, HAS 104386, HAS 104391, HAS 104396, HAS 104414. 
Tabela 12: Principais características comparativas entre as espécies de Planktolyngbya documentadas no presente trabalho.

\begin{tabular}{lll}
\hline & $\boldsymbol{P}$. contorta & $\boldsymbol{P}$. limnetica \\
\hline Filamentos & solitários, espiralados & solitários, retos ou flexuosos \\
Bainha mucilaginosa & fina, homogênea, incolor & fina, homogênea, incolor \\
Diâmetro $(\mu \mathrm{m})$ & $1,6-2,0$ & $1,0-2,0$ \\
Tricomas & $\begin{array}{l}\text { não atenuados, } \\
\text { não constritos }\end{array}$ & $\begin{array}{l}\text { não atenuados, } \\
\text { não constritos }\end{array}$ \\
Diâmetro $(\mu \mathrm{m})$ & $1,3-1,7$ & $0,8-1,7$ \\
Células & & \\
Comprimento $(\mu \mathrm{m})$ & $2,8-4,5$ & $3,0-5,0$ \\
RC/L & $1,7-3,5$ & $1,6-5,0$ \\
Conteúdo celular & verde-azulado, homogêneo & verde-azulado, homogêneo \\
Septos & granuloso ou não & granuloso ou não \\
Hábitat & plâncton & plâncton \\
\hline
\end{tabular}

Subfamília Spirulinoideae Komárek et Anagnostidis, 2005.

\section{Spirulina Turpin ex Gomont, 1892.}

Espécie-tipo: Spirulina major Kützing ex Gomont, Ann. Sci. nat. Sér. 7, v. 16, p. 251. 1892.

O gênero Spirulina é caracterizado por desenvolver tricomas espiralados, não constritos, com movimento intenso; células isodiamétricas a mais longas que largas.

O gênero Spirulina, durante muito tempo, foi estreitamente relacionado com o gênero Arthrospira Stizenberger ex Gomont. Segundo Gomont (1892), Spirulina e Arthrospira pertencem a subtribos diferentes de Lyngbyeae, Spirulinoideae e Oscillatorioideae, respectivamente. No entanto, Frémy (1929-1933, 1930) e Geitler (1932) incluíram as espécies de ambos os gêneros em Spirulina. Mais tarde, Bourrelly (1970b) incluiu os dois gêneros em Oscillatoria, em seções diferentes (Spirulina, com septos transversais não visualizáveis e Arthrospira, com septos transversais visíveis).

Segundo Anagnostidis \& Komárek (1988), Arthrospira e Spirulina são classificados como gêneros diferentes, pertencendo à subfamília Spirulinoideae de Phormidiaceae e as característicias utilizadas para distingui-los são: padrão de poros e perfurações das paredes celulares, regularidade das espiras (menor em Arthrospira), presença de caliptra em algumas espécies de Arthrospira e movimento, que é mais intenso em Spirulina. 
Posteriormente, Komárek \& Anagnostidis (2005) classificaram Arthrospira em Phormidiaceae, por desenvolver tricomas com células isodiamétricas ou mais curtas que largas e necrídios na reprodução por fragmentação e Spirulina em Pseudanabaenaceae, por exibir tricomas com células isodiamétricas ou mais longas que largas e não formar necrídios na fragmentação dos tricomas. Segundo eles, estudos moleculares mostram que Spirulina é um gênero distintamente separado do grupo de cianobactérias que pertencem a Pseudanabaenaceae e Hoffmann et al. (2005) classificaram-no em Chroococcales (subclasse Oscillatoriophycidae). Mais recentemente, Komárek (2006) reposicionou Spirulina em Oscillatoriales, por tratar-se de um gênero filamentoso.

No presente estudo apenas uma espécie de Spirulina foi observada (Spirulina laxissima $\mathrm{f}$. major).

Spirulina laxissima G. S. West, in Cyanophyta, p. 618. 1959.

(Figs. 8E, 12I)

Tricomas solitários, frouxamente espiralados, não atenuados, não constritos, 1,4-2,0 $\mu \mathrm{m}$ diâm.; espiras 5,0-6,2 $\mu \mathrm{m}$ alt., 8,0-12,5 $\mu \mathrm{m}$ distantes umas das outras; conteúdo celular verde-azulado, homogêneo, sem aerótopos.

A população observada apresentou valores de diâmetro celular que ampliam o intervalo referido por Desikachary (1959), no entanto, estão de acordo com as populações observadas para o estado de São Paulo por Sant'Anna \& Azevedo (1995). Em relação à altura das espiras, os espécimes observados estão de acordo com Desikachary (1959), porém apresentaram uma variação maior quanto à distância entre as espiras.

No presente estudo, Spirulina laxissima f. major foi observada apenas no plâncton. Material examinado: HAS 104134. 


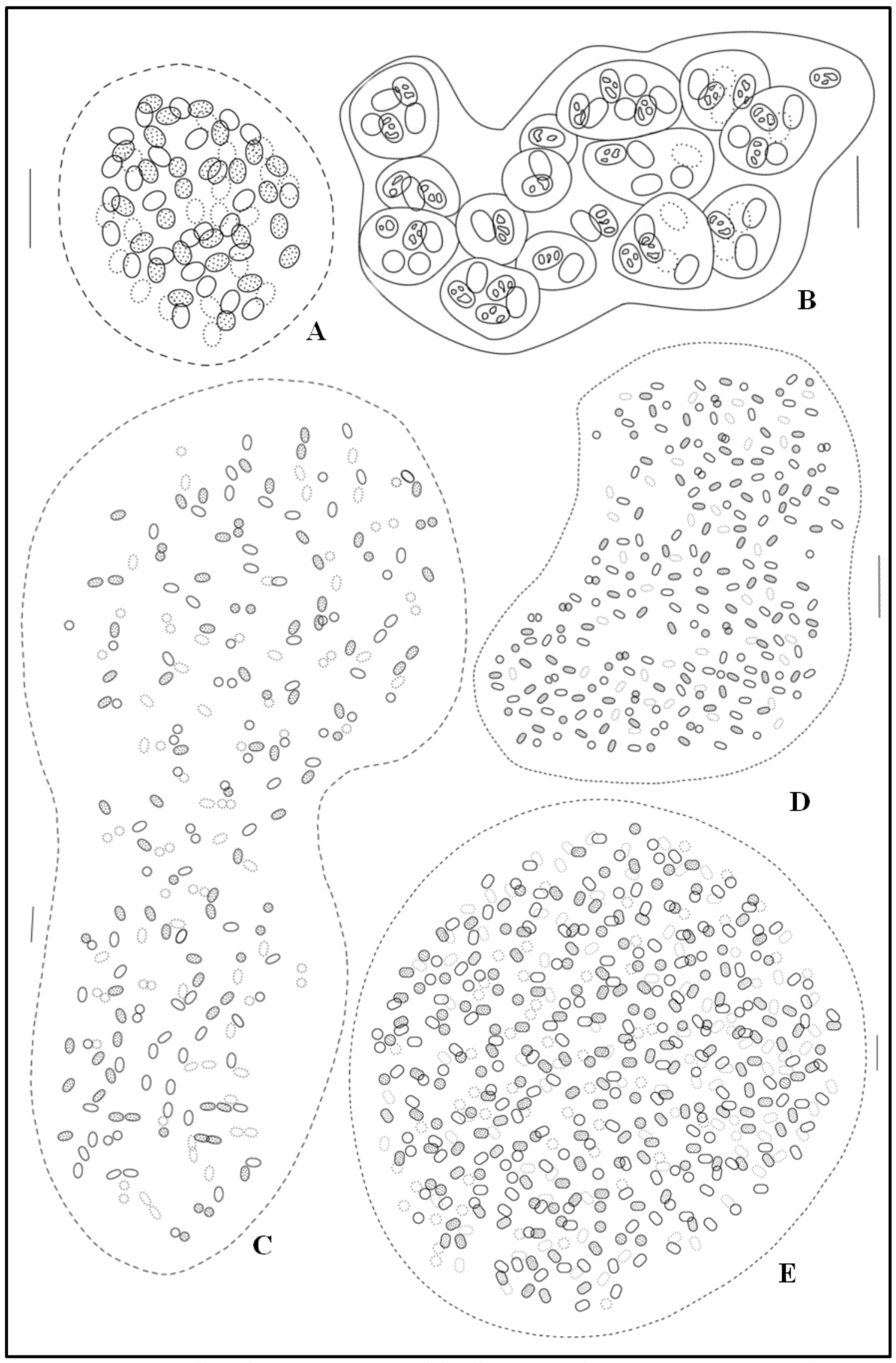

Fig. 3: A-E. A. Aphanothece comasii Komárková-Legnerová et Tavera; B. A. conglomerata Rich; C. A. smithii Komárková-Legnerová et Cronberg; D. A. minutissima (W. West) Komárková-Legnerová et Cronberg; E. A. stagnina (Sprengel) A. Braun. Escalas: A-D $=10$ $\mu \mathrm{m} ; \mathrm{E}=20 \mu \mathrm{m}$. 


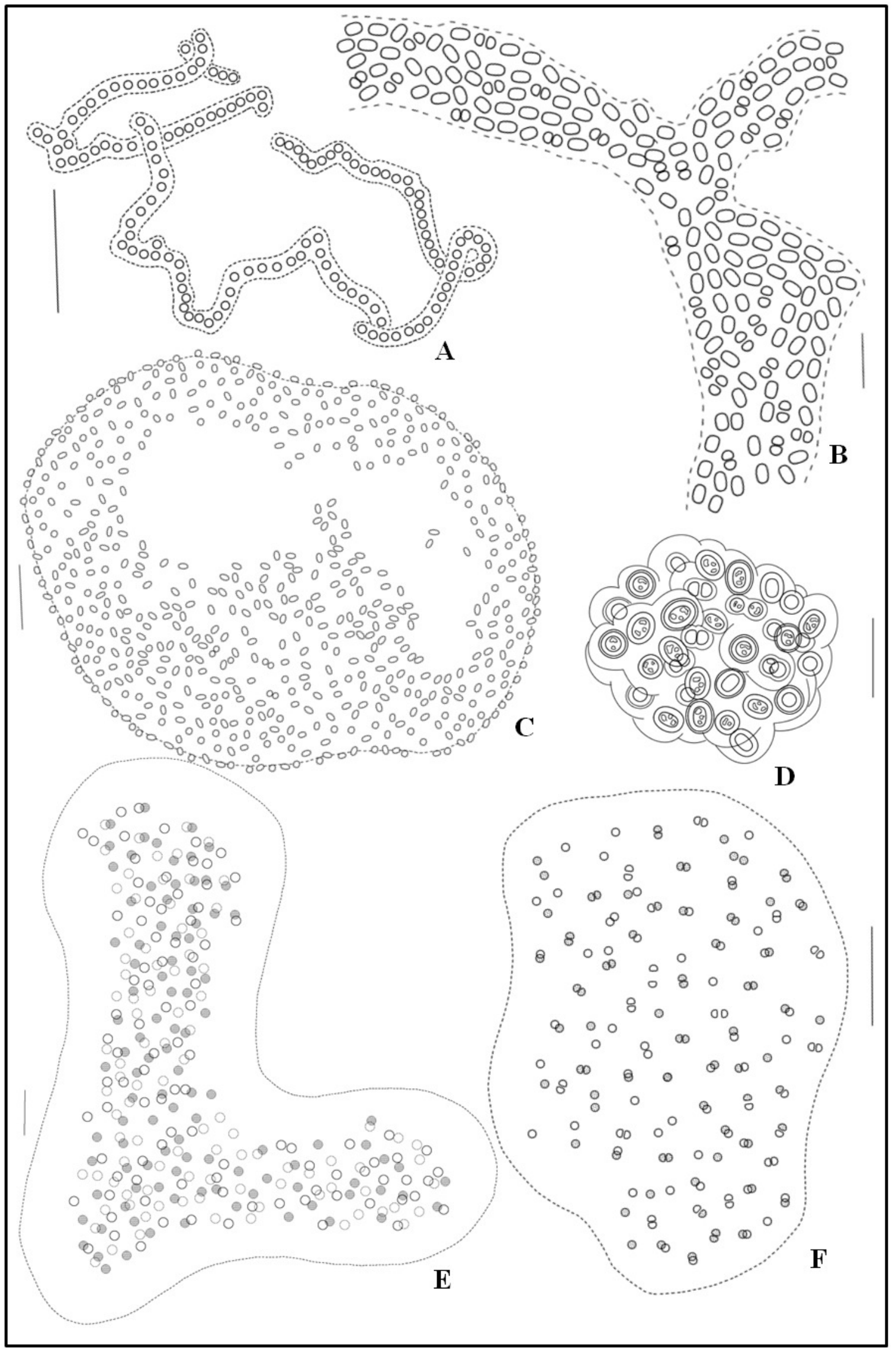

Fig. 4: A-F. A. Cyanodictyon reticulatum (Lemmermann) Geitler; B. C. tubifonme Cronberg; C. Epigloeosphaera sp.; D. Gloeothece incerta Skuja; E. Aphanocapsa conferta (W. et G. S. West) Komárková-Legnerová et Cronberg; F. A. delicatissima W. et G. S. West. Escalas: A, B, $\mathrm{D}, \mathrm{F}=10 \mu \mathrm{m} ; \mathrm{C}, \mathrm{E}=20 \mu \mathrm{m}$. 


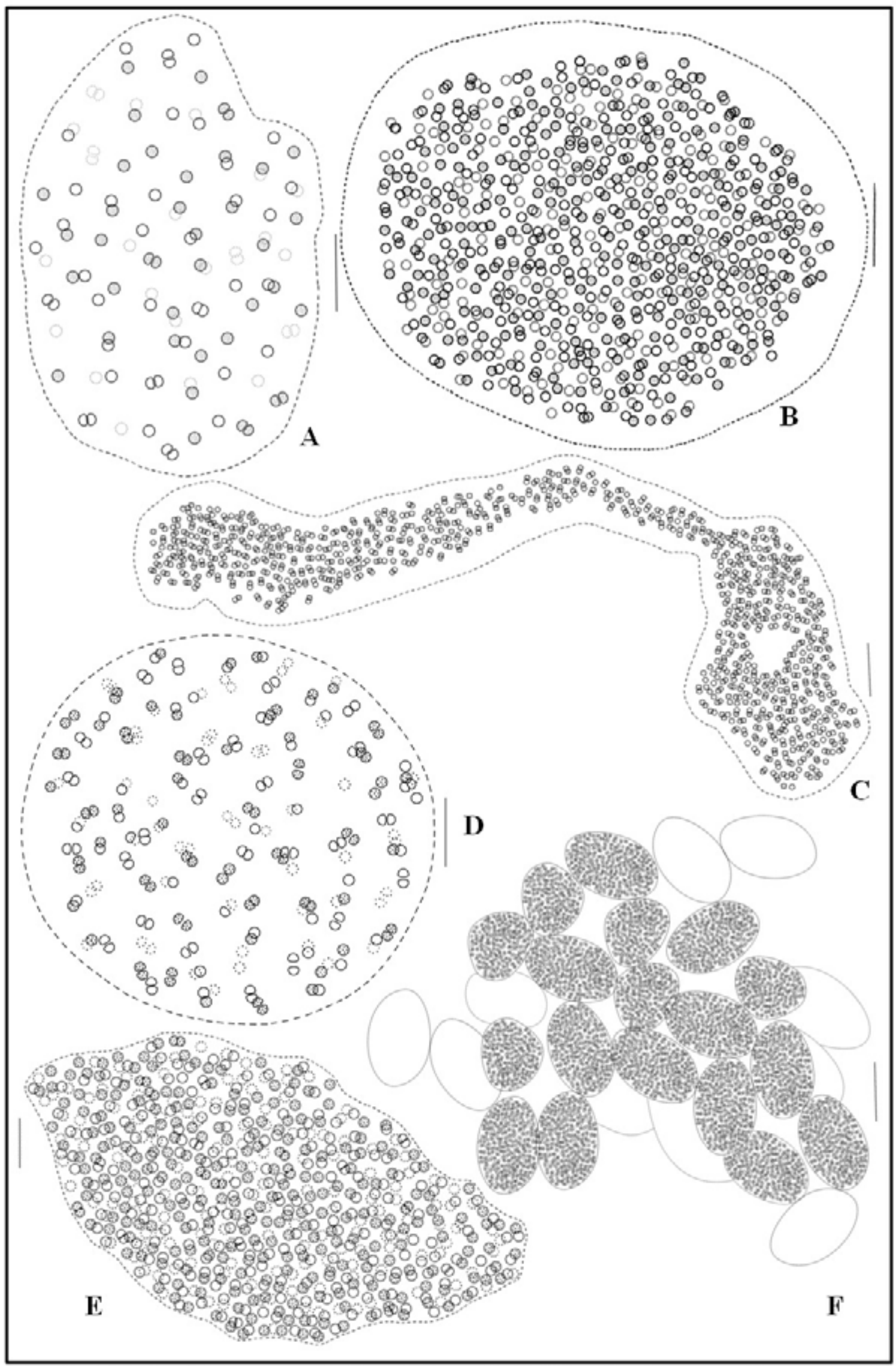

Fig. 5: A-F. A. Aphanocapsa elachista W. et. G. S. West; B. A. incerta (Lemmemamu) Cronberg et Komárek; C. A. holsatica (Lemmermann) Cronberg et Komárek; D. A. koordersii StrØm; E-F. A. cf. incerta (Lemmermann) Cronberg et Komárek. E. colônia isolada; F. colônias agregadas. Escalas: $\mathrm{A}-\mathrm{C}, \mathrm{E}=10 \mu \mathrm{m} ; \mathrm{D}=20 \mu \mathrm{m} ; \mathrm{F}=50 \mu \mathrm{m}$. 


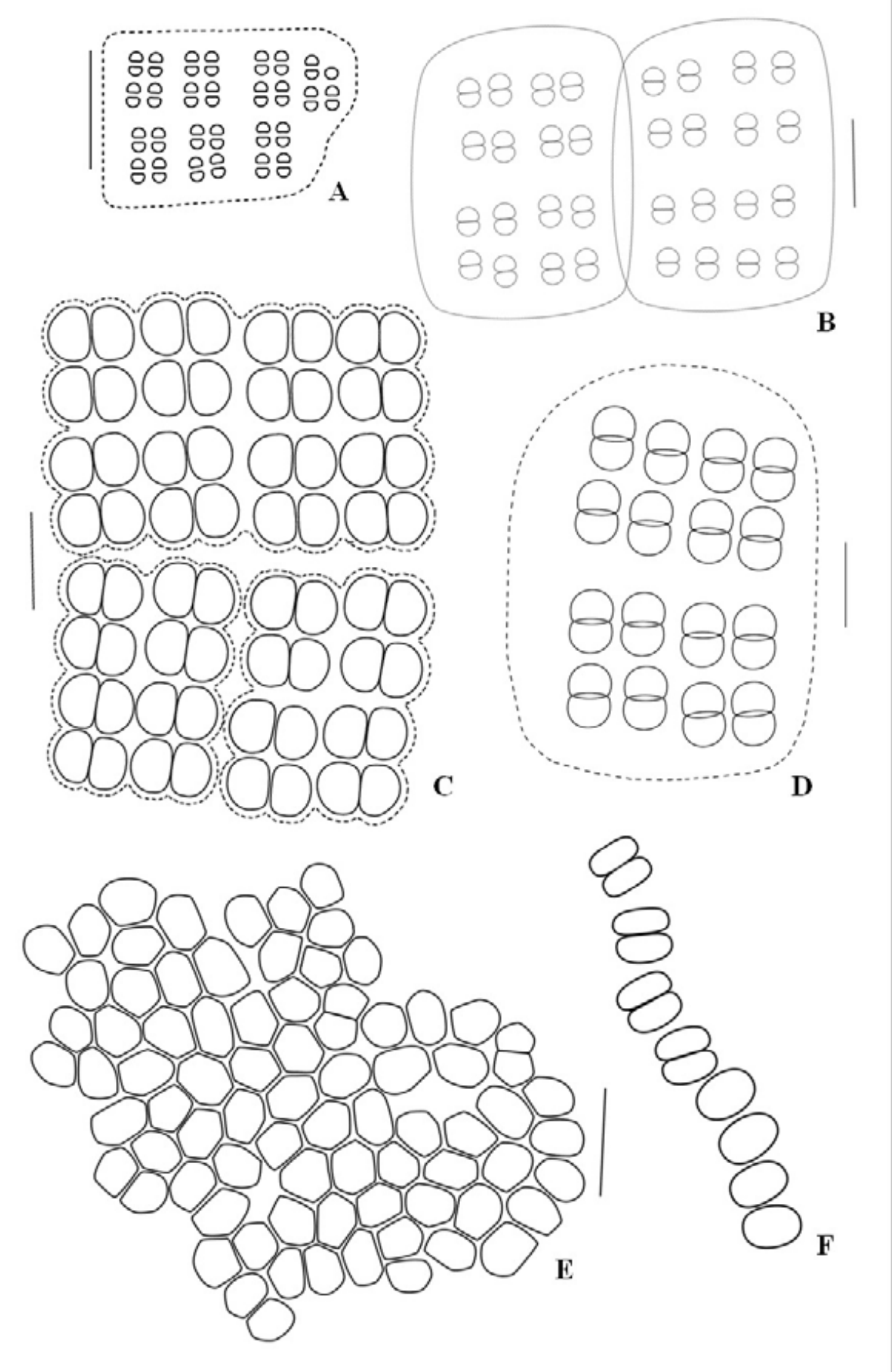

Fig. 6: A-F. A. Merismopedia tenuissima Lemmermann; B. M. punctata Meyen; C. M. elegans A. Braun in Kützing; D. M. glauca (Ehrenberg) Kützing; E-F. Microcrocis pulchella (Buell) Geitler. E. colônia em vista apical; F. células em vista lateral. Escalas: $10 \mu \mathrm{m}$. 


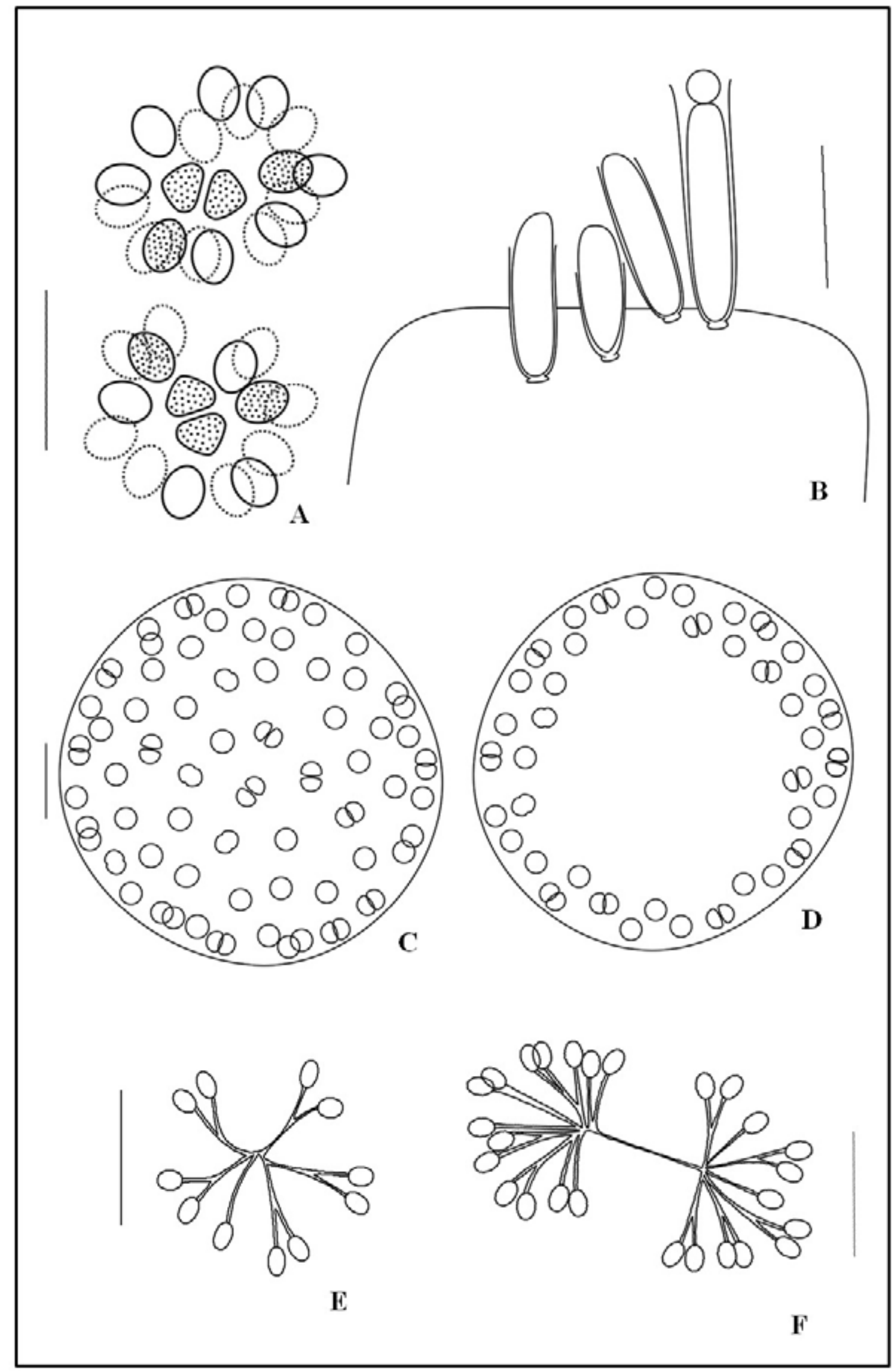

Fig. 7: A-F. A. Coelomoron pusillum (Van Goor) Komárek; B. Chanaesiphon amethystimus (Rotafinski) Lemmermann; C-D. Coelosphaerium kuetzingiamum Nägeli; E-F. Snowella lacustris (Chodat) Komárek et Hindák. Escalas: $10 \mu \mathrm{m}$. 


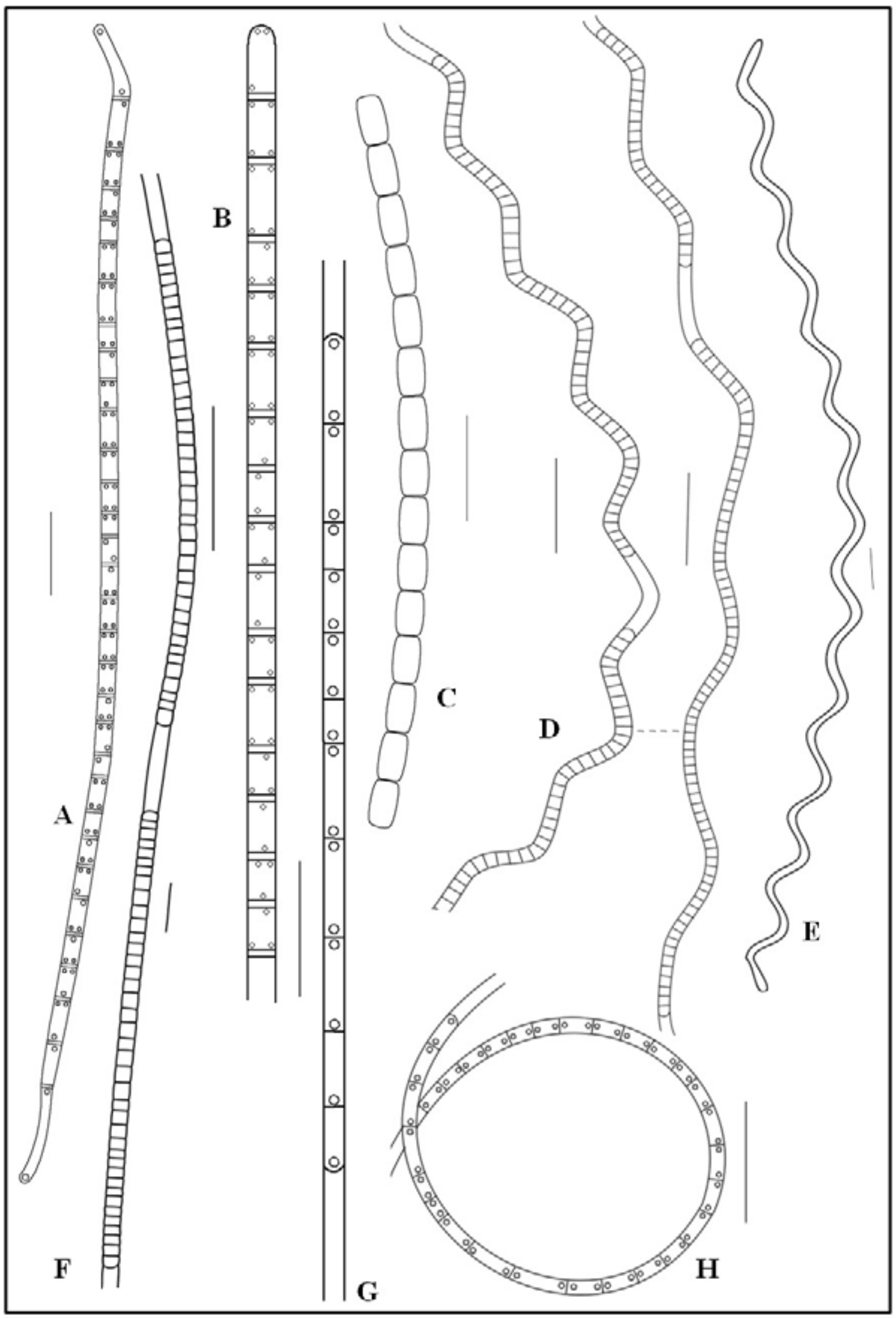

Fig. 8: A-H. A. Geitlerinema splendidum (Greville ex Gomont) Anagnostidis; B. G. amphibium (Greville ex Gomont) Anagnostidis; C. Pseudanabaena catenata Lauterbon; D. Leptolyngbya lagerheimii (Gomont) Anagnostidis et Komárek; E. Spinulina laxissima G. S. West; F. Leptolyngbya cebennensis (Gomont) Umezali et M. Watanabe; G. Planktolyngbya limnetica (Lemmermann) Komárková-Legnerová et Cronberg; H. P. contorta (Lemmermann) Anagnostidis et Komárek. Escalas: $10 \mu \mathrm{m}$. 


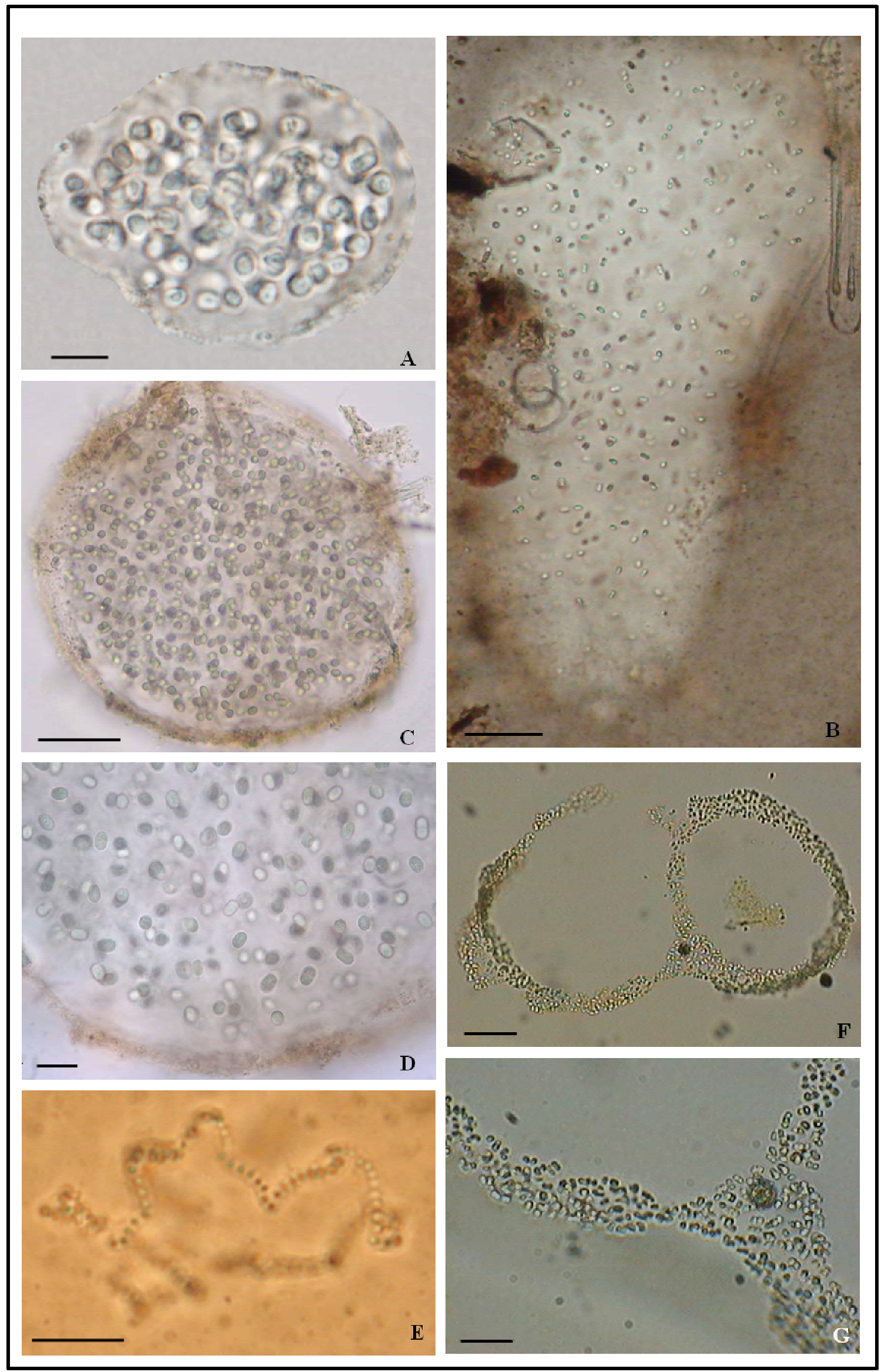

Fig. 9: A-G. A. Aphonothece conasi Komádová-L egnerová et Tavera; B. A. smithi KomádiováLegnerova et Cronberg: C-D. A. stagnina (Sprengel) A. Brann.: E. Cranodictron reticulatum (Lemmermann) Geitler: F-G. C. nbifonme Cronberg. Escalas: A. E. G $=10 \mu \mathrm{m}$. B. D. F $=20 \mu \mathrm{m}$ : $\mathrm{C}=50 \mathrm{\mu m}$. 

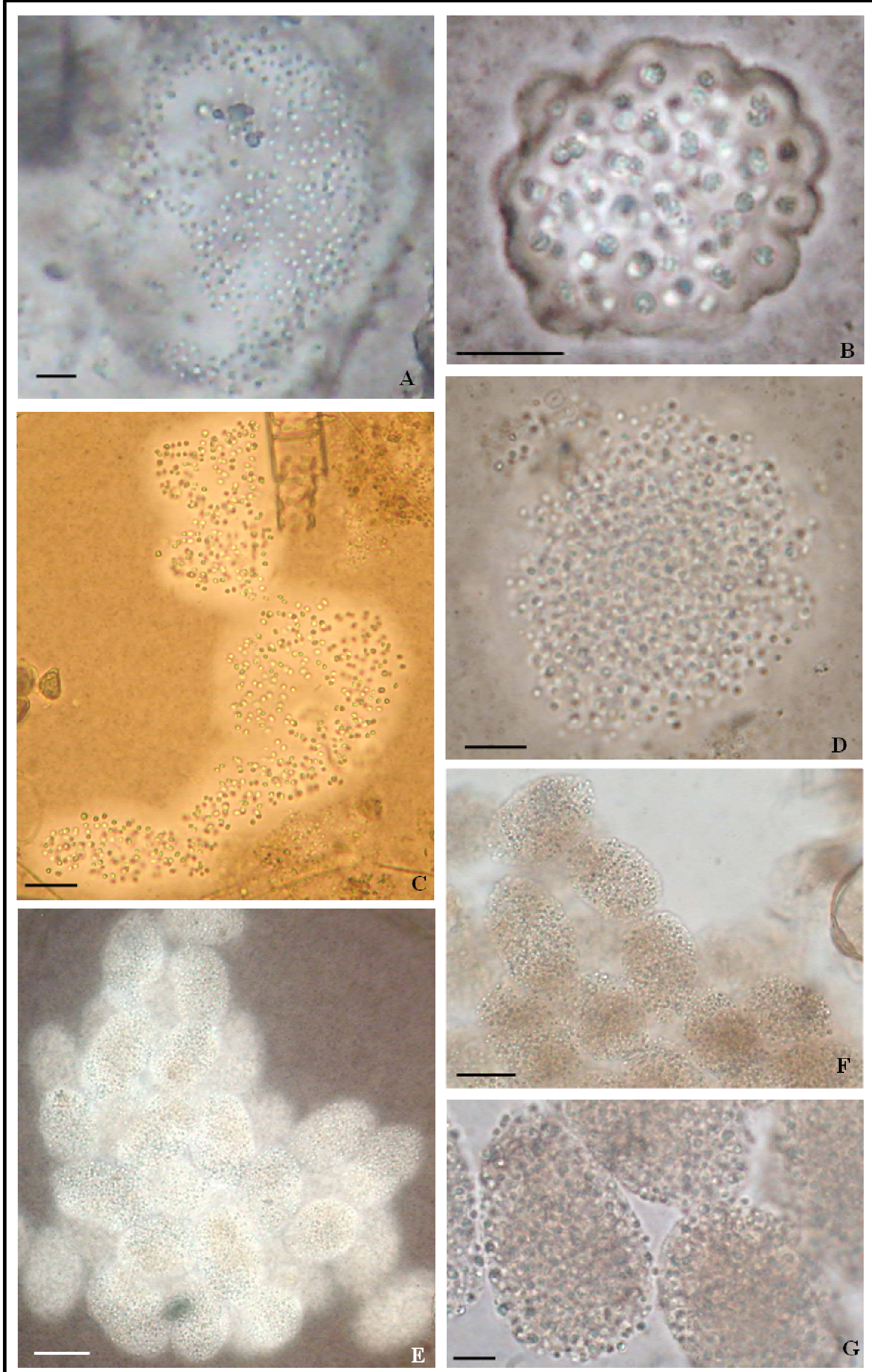

Fig. 10: A-G. A. Epighoeosphaera sp.: B. Gloeothece imcerta Slața: C. Aphanocapsa confenta (W. et G. S. West) Komáulovà-Legnerova et Cronberg: D. A. incerta (Lemmennaun) Cronberg et Komàe:E-G. A. cf. morta (Lemmemann) Cronberg et Komade. E, G. colonias agregadas, F. detalle das colonias Escalas: A, B, D. G $=10 \mu \mathrm{m}, \mathrm{C}=20 \mu \mathrm{m}: \mathrm{E}, \mathrm{F}=50 \mu \mathrm{m}$. 


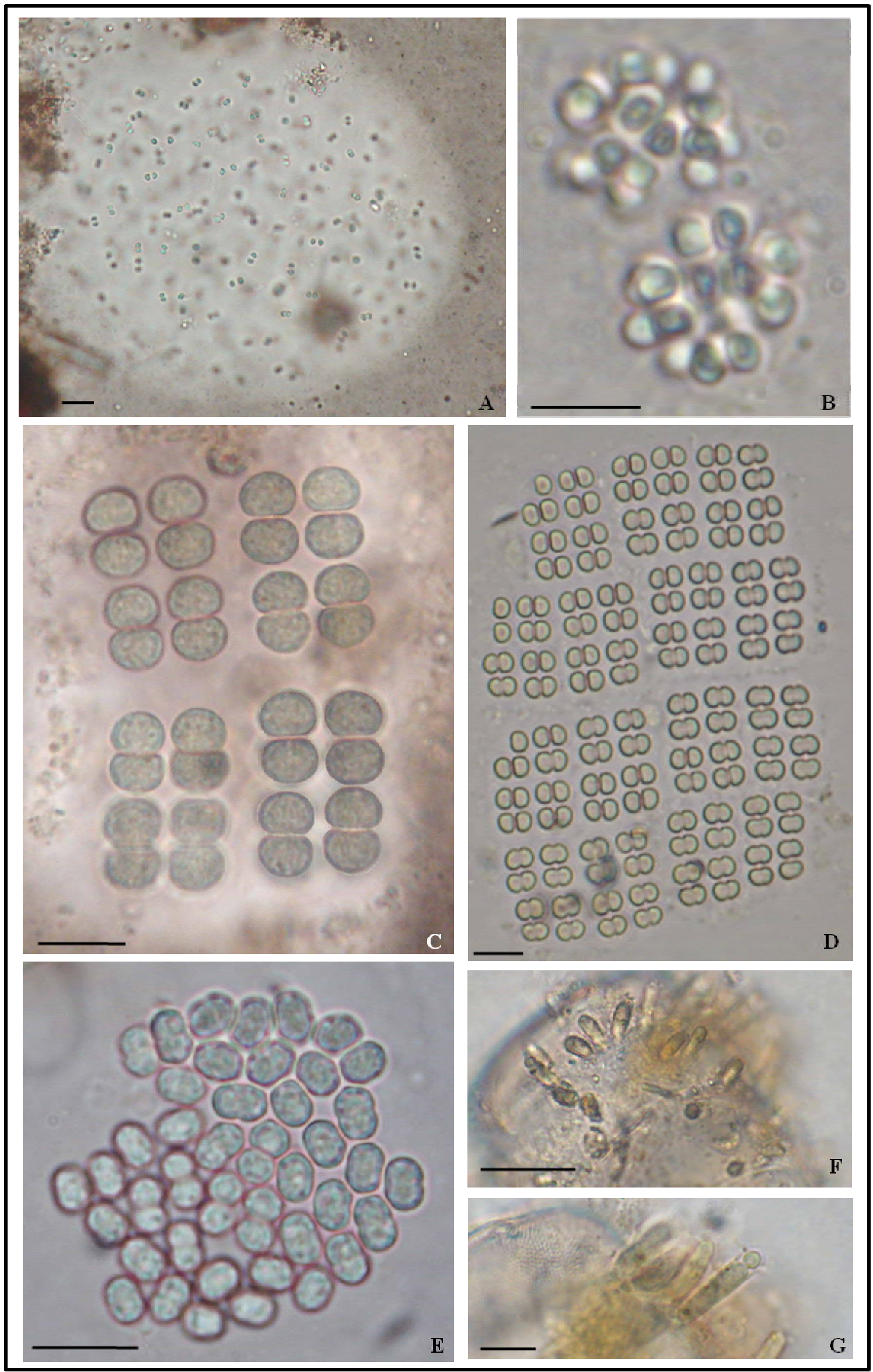

Fig. 11: A-G. A. Aphanocarsa hoordersin StrCm: B. Coelonoron pusilhm (Van Goor) Komàel:: C. Mertsunopedia elegoms A. Braun in Kützing: D. M. glatca (Elwenberg) Kützing: E. Microcrocis pulchella (Buell) Geitlei. F-G. Chamaesiphon amethrstmus (Rostafinsli) Lemmemann. Escalas: $\mathrm{B}-\mathrm{E}, \mathrm{G}=10 \mu \mathrm{m} ; \mathrm{A}, \mathrm{F}=20 \mu \mathrm{m}$. 


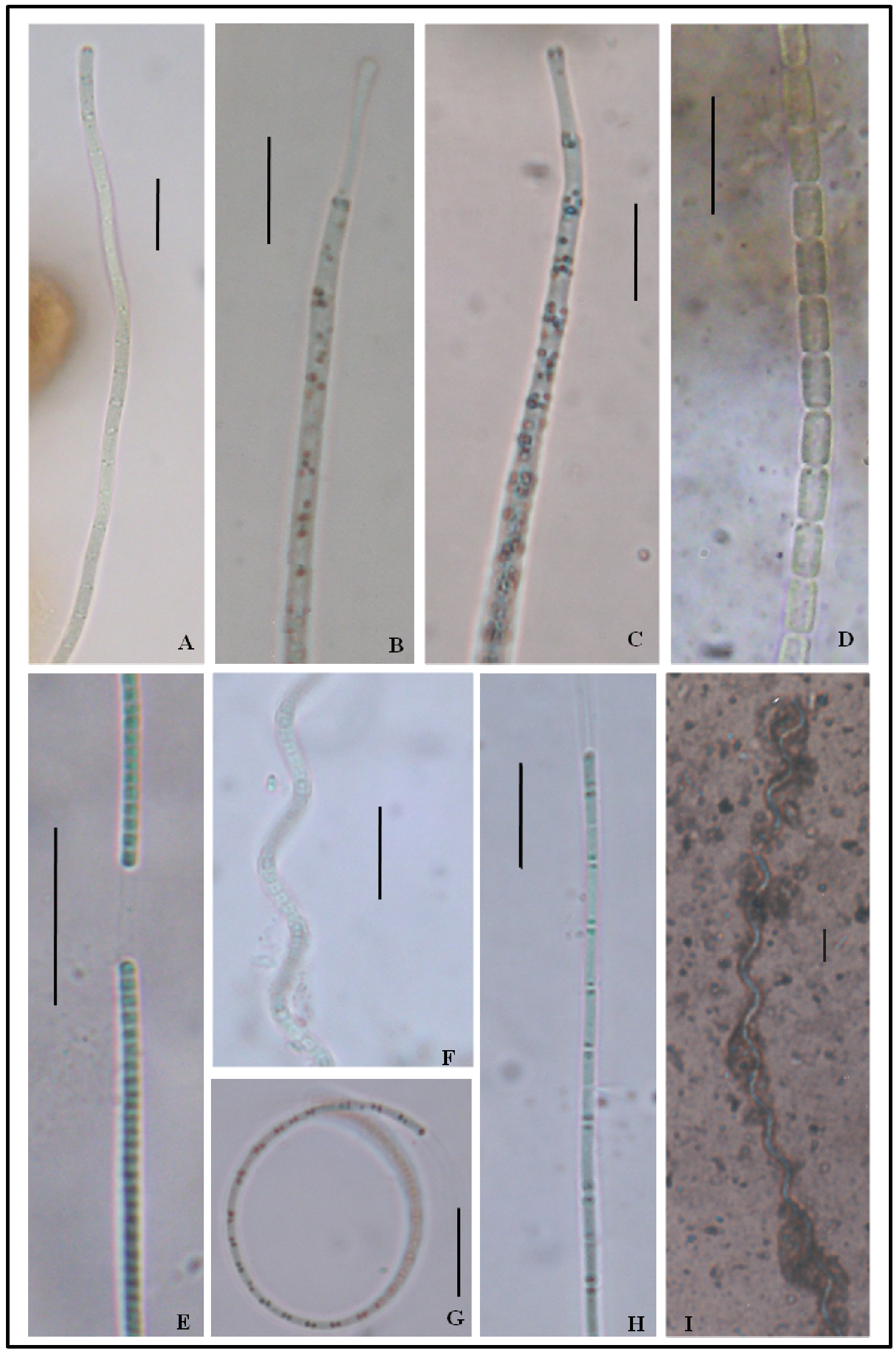

Fig. 12: A-I. A. Geitlerimema amphibium (Agardh ex Gomont) Anagnostidis: B-C. G. splendidum (Greville ex Gomont) Anagnostidis: D. F'seldanabaena catenata Lanterbom: $\mathbf{E}$. Leptohngbia cebemensis (Gomont) Umezali et M. Watanabe: F. L. lagerheimii (Gomont) Anagnostidis et Komarel: G. Flanhtolngbra contorta (Lemmemann) Anagnostidis et Komarel: H. F. limmetica (Lemmermann) Komathova-Legnerova et Conberg: I. Spinthima laxissima G. S. West. Escalas: $10 \mu \mathrm{m}$. 


\subsection{OSCILLATORIOPHYCIDAE}

A subclasse Oscillatoriophycidae abrange cianobactérias unicelulares e filamentosas que apresentam tilacoides dispostos radialmente nas células. É composta por duas ordens, Chroococcales e Oscillatoriales, que diferem entre si pela morfologia do talo.

\section{CHROOCOCCALES}

A ordem Chroococcales é composta pelas cianobactérias que apresentam tilacoides dispostos radialmente na célula. A ordem compreende organismos unicelulares ou pseudofilamentosas e uma única família de cianobactérias filamentosas.

As classificações anteriores a Hoffmann et al. (2005) incluíam apenas organismos unicelulares em Chroococcales. Segundo Geitler (1932), a ordem era dividida em duas famílias (Chroococcaceae e Entophysalidaceae), caracterizadas pela morfologia do talo. De acordo com Komárek \& Anagnostidis (1986), Chroococcales era composta por sete famílias (Microcystaceae, Chroococcaceae, Entophysalidaceae, Chamaesiphonaceae, Dermocarpellaceae, Xenococcaceae e Hydrococcaceae) e, posteriormente, Komárek \& Anagnostidis (1998) dividiram a ordem em 11 famílias (Gloeobacteriaceae, Synechococcaceae, Merismopediaceae, Microcystaceae, Chroococcaceae, Entophysalidaceae, Hydrococcaceae, Chamaesiphonaceae, Dermocarpellaceae, Xenococcaceae e Hyellaceae).

Segundo Hoffmann et al. (2005), a ordem Chroococcales é composta por aproximadamente 100 gêneros, divididos em 11 famílias (Cyanobacteriaceae, Microcystaceae, Gomphosphaeriaceae, Chroococcaceae, Entophysalidaceae, Stichosiphonaceae, Dermocarpellaceae, Xenococcaceae, Hydrococcaceae e Spirulinaceae). Dessas 11 famílias, apenas Spirulinoideae é composta por organismos filamentosos e por esta razão, posteriormente Komárek (2006) classificou-a em Oscillatoriales.

No presente estudo foram registradas 12 espécies de Chroococcales, distribuídos em três gêneros e classificados nas famílias Microcystaceae (5) e Chroococcaceae (7). 


\section{CHAVE PARA IDENTIFICAÇÃO DAS FAMÍLIAS ENCONTRADAS}

1. Divisão celular em 3 planos, células-filhas atingem o tamanho original antes da próxima divisão Microcystaceae

1. Divisão celular em 3 ou mais planos, células-filhas não atingem o tamanho original antes da próxima divisão Chroococcaceae

\section{MICROCYSTACEAE Elenkin, 1933.}

A família caracteriza-se por desenvolver colônias com células dispostas irregularmente ou formando fileiras perpendiculares nas colônias; mucilagem homogênea ou lamelada, contorno evidente ou difluente; células esféricas ou hemisféricas, com ou sem envelope mucilaginoso; com ou sem aerótopos; reprodução pela desintegração da colônia (Komárek \& Anagnostidis, 1998).

Segundo Komárek \& Anagnostidis (1998), Microcystaceae é definida por apresentar células esféricas ou hemisféricas e pela divisão celular ocorrer em três planos em sucessivas gerações. No entanto, segundo Hoffmann et al. (2005), essas características não podem definir Microcystaceae, pois alguns gêneros que foram incluídos na família, como Radiocystis Skuja, apresentam divisão celular em apenas um plano nas sucessivas gerações. Outras mudanças foram propostas por eles: inclusão do gênero Sphaerocavum Azevedo et Sant'Anna e de algumas espécies de Aphanocapsa e Synechocystis, além da exclusão de Eucapsis, que foi reposicionado em Merismopediaceae (subclasse Synechococcophycidae).

Microcystaceae, segundo Komárek \& Anagnostidis (1998), compreende quatro gêneros, Chondrocystis, Eucapsis, Gloeocapsa e Microcystis, diferenciados pelo aspecto da colônia, distribuição das células na mucilagem colonial e presença de envelope mucilaginoso.

No presente estudo foi registrada a ocorrência de cinco espécies distribuídas em dois gêneros, Eucapsis (1) e Microcystis (4).

\section{CHAVE PARA IDENTIFICAÇÃO DOS GÊNEROS ENCONTRADOS}

1. Células dispostas em fileiras perpendiculares na colônia, sem aerótopos Eucapsis

1. Células dispostas irregularmente na colônia, com aerótopos Microcystis 


\section{Eucapsis Clement et Shantz, 1909.}

Espécie-tipo: Eucapsis alpina Clement et Shantz, Minn. Bot. Stud., v. 4, p. 134. 1909.

Eucapsis é um gênero principalmente metafítico e, menos comumente, planctônico, que se caracteriza por apresentar colônias com células dispostas em fileiras perpendiculares resultando em colônias cúbicas; mucilagem incolor, difluente ou evidente; células esféricas, ovais ou hemisféricas após a divisão; as células se dividem em três planos em sucessivas gerações e a reprodução se dá a partir da desintegração da colônia.

Segundo Komárek \& Anagnostidis (1998), as colônias são pequenas, com o número de células variando entre 4 a 128. Komárek \& Hindák (1989) comentam que as espécies do gênero diferenciam-se pelas dimensões celulares e ecologia. Segundo esses autores, as espécies do gênero apresentam ampla distribuição geográfica, porém ocupam hábitats bem definidos.

Algumas espécies de Chroococcus podem ser confundidas com Eucapsis por apresentarem colônias com poucas células formando colônias cúbicas. Em muitas espécies de Chroococcus, as células são hemisféricas ou poligonais e não atingem o tamanho original antes da próxima divisão celular, diferindo assim de Eucapsis. De qualquer modo, ambos os gêneros contêm espécies problemáticas, com características intermediárias.

Eucapsis parallelepipedon foi a única espécie representante do gênero registrada no presente estudo.

Eucapsis parallelepipedon (Schmidle) Komárek et Hindák, Acta Hydrobiol. v. 31, n. 1/2, p. 32. 1989.

Basônimo: Chroococcus parallelepipedon Schmidle, Engler Bot. Jahrd. v. 30, p. 242. 1901.

(Figs. 13A, 19A)

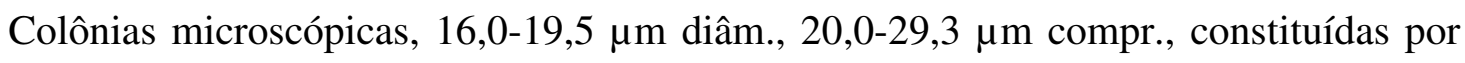
(4) 8-32 células dispostas em grupos de 4; mucilagem homogênea, firme, incolor, margem difluente; células esféricas, 2,4-3,5 ㅆm diâm.; conteúdo celular verde-azulado, homogêneo; sem aerótopos.

Os espécimes encontrados apresentaram características morfológicas e métricas que estão de acordo com as referidas para E. parallelepipedon por Komárek \& Anagnostidis (1998). Segundo Azevedo et al. (2003), no Brasil ocorrem duas espécies de Eucapsis: E. densa Azevedo et al. e E. parallelepipedon. Ambas apresentam células com diâmetros que se sobrepõem. Eucapsis densa tem maior variação métrica das células, apresenta células com distribuição mais agregada na colônia e é mais comum no metafíton. As populações estudadas 
foram identificadas como Eucapsis parallelepipedon com base nas características morfológicas e métricas observadas e no fato delas terem sido registradas apenas no plâncton. Material examinado: HAS 104202, HAS 104451.

\section{Microcystis Kützing ex Lemmermann, 1907.}

Espécie-tipo: Microcystis aeruginosa (Kützing) Kützing, Tab. Phycol., v. 1, p. 6. 1846.

O gênero Microcystis caracteriza-se por desenvolver colônias micro ou macroscópicas, planctônicas, esféricas, ovais, lobadas a irregulares ou alongadas, clatradas em algumas espécies, às vezes, compostas por subcolônias; células dispostas esparsa ou densa e irregularmente na colônia; mucilagem incolor, homogênea ou indistintamente lamelada, margem difluente ou evidente; células esféricas ou hemisféricas, com ou sem envelope mucilaginoso; com aerótopos; divisão celular por fissão binária em três planos; as células atingem tamanho e forma originais antes da próxima divisão; reprodução por desintegração da colônia em pequenos grupos de células ou através de uma única célula (KOMÁREK \& ANAGNOSTIDIS, 1998).

Microcystis é um dos gêneros mais frequentemente associados a florações de cianobactérias, sendo $M$. aeruginosa (Kützing) Kützing a espécie mais encontrada em florações tóxicas (KOMÁREK \& KOMÁRKOVÁ, 2002).

Segundo Komárek (1991), trata-se de um gênero de difícil taxonomia, pois a grande variabilidade morfológica exibida pelas espécies dificulta a delimitação das mesmas.

Estudos moleculares com espécies de Microcystis têm mostrado que o gênero é genotipicamente bem delimitado, no entanto, não são detectadas unidades subgenéricas, e todas as espécies morfologicamente delimitadas tratam-se de uma mesma espécie sob o conceito molecular (KOMÁREK \& KOMÁRKOVÁ, 2002).

Segundo Komárek (2003), Microcystis compreende cerca de 25 morfoespécies descritas e as principais características usadas na identificação dessas espécies são morfologia da colônia, estrutura da mucilagem, diâmetro celular, disposição das células na colônia e o ciclo de vida.

No presente estudo foram identificadas quatro espécies de Microcystis: M. aeruginosa, M. protocystis, M. smithii e M. wesenbergii.

\section{Chave para identificação das espécies encontradas}

1. Células até $4,5 \mu \mathrm{m}$ diâm. .M. smithii

1. Células maiores que 4,5 $\mu \mathrm{m}$ diâm. .2 
2. Colônias lobadas, mucilagem colonial com margem evidente M. wesenbergii

2. Colônias não lobadas, mucilagem colonial com margem difluente 3

3. Células densamente arranjadas na colônia M. aeruginosa

3. Células esparsamente arranjadas na colônia. M. protocystis

Microcystis aeruginosa (Kützing) Kützing, Tab. Phycol., v. 1, p. 6. 1846.

Basônimo: Micraloa aeruginosa Kützing, Linnaea, 8, p. 371. 1833.

(Figs. 13B-C, 19B-D)

Colônias microscópicas, irregulares, geralmente alongadas, lobadas, clatradas ou não, 45,0-127,0 $\mu \mathrm{m}$ diâm., 68,0-335,0 $\mu \mathrm{m}$ compr.; células dispostas irregularmente e próximas umas das outras; mucilagem homogênea, incolor, firme, margem difluente e ampla; células esféricas ou levemente alongadas, 4,5-6,5 $\mu \mathrm{m}$ diâm.; conteúdo celular verde-azulado; com numerosos aerótopos.

Os espécimes analisados apresentam características morfológicas e métricas que estão de acordo com as referidas para a espécie por Komárek \& Anagnostidis (1998).

Microcystis aeruginosa é considerada uma espécie cosmopolita, no entanto, Komárek (1991) comenta que a ampla distribuição observada para a espécie pode ser resultado de erros de identificação. Ainda segundo o autor, M. aeruginosa pode ser confundida com $M$. flosaquae (Wittrock) Kirchner, embora as duas espécies sejam distintas quanto à dimensão celular, forma da colônia e distribuição das células.

Microcystis protocystis Crow apresenta células com diâmetro celular semelhante a $M$. aeruginosa, entretanto as células se dispõem mais frouxamente na colônia nesta última.

A espécie em questão é amplamente conhecida por formar florações em todo o mundo, sendo a mais encontrada em florações tóxicas. No Brasil, o caso mais expressivo de intoxicação causada pela espécie, foi registrado em Caruaru, estado de Pernambuco, onde o uso de água contaminada com microcistina em tratamento de hemodiálise causou a morte de 76 pessoas (YUAN et al., 2006).

A ocorrência de florações tóxicas de $M$. aeruginosa já foi registrada na laguna dos Patos, causando mortandade de peixes (YUNES et al., 1996; YUNES et al., 1998).

No presente trabalho, as populações estudadas ocorreram somente no plâncton. Material examinado: HAS 104106, HAS 104142, HAS 104167, HAS 104339, HAS 104343, HAS 104351, HAS 104370, HAS 104372, HAS 104376, HAS 104396, HAS 104399. 
Microcystis protocystis Crow, New Phytol., v. 22, n. 2, p. 62.1923.

(Figs. 13D, 19E)

Colônias microscópicas, esféricas, alongadas ou irregulares, 125,0-305,3 $\mu \mathrm{m}$ diâm.,

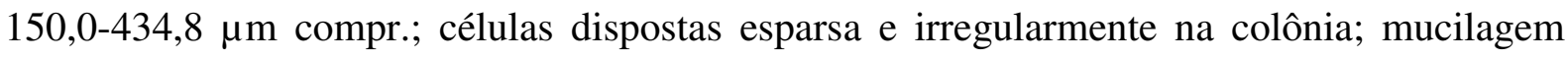
homogênea, incolor, firme, margem difluente; células esféricas, com envelope mucilaginoso, 4,5-6,5 ㅆm diâm.; conteúdo celular verde-azulado; com aerótopos.

Os espécimes analisados apresentaram as características morfométricas referidas para a espécie por Komárek \& Anagnostidis (1998), no entanto, nem todas as células na colônia apresentaram envelope mucilaginoso visível. Embora $M$. protocystis seja semelhante a $M$. aeruginosa, principalmente pela sobreposição das dimensões celulares, $M$. protocystis se distingue das demais espécies do gênero por exibir envelope mucilaginoso individual e células que se dispõem mais esparsamente.

Segundo Sant'Anna et al. (2004), a disposição mais frouxa das células apresentada por $M$. protocystis se assemelha a colônias adultas ou senescentes de outras espécies de Microcystis. Devido a esta razão, a distribuição da espécie pode ser mais ampla do que a normalmente referida para a espécie.

Os exemplares observados foram registrados apenas no plâncton dos ambientes amostrados.

Material examinado: HAS 104106, HAS 104369, HAS 104451.

Microcystis smithii Komárek et Anagnostidis, Preslia, v. 67, p. 21. 1995.

(Figs. 14B, 20A-C)

Colônias microscópicas, esféricas, ovais ou alongadas, 80,5-150,0 $\mu \mathrm{m}$ diâm., 93,0357,0 $\mu \mathrm{m}$ compr.; células dispostas esparsa e irregularmente, solitárias ou aos pares na colônia; mucilagem homogênea, incolor, firme, margem difluente; células esféricas, 3,5-4,5 $\mu$ m diâm.; conteúdo celular verde-azulado; com um ou poucos aerótopos.

Os espécimes observados apresentam características que estão de acordo com as referidas para a espécie (KOMÁREK \& ANAGNOSTIDIS, 1998).

Microcystis smithii é uma espécie que apresenta colônias com células frouxa e irregularmente dispostas na mucilagem. Devido ao fato de muitas de suas células estarem ao pares, seus representantes assemelham-se a Aphanocapsa, no entanto, a presença dos aerótopos permite a diferenciação, pois esses não são formados em organismos desse último gênero.

A população analisada foi registrada apenas no plâncton da lagoa do Charutão. 
Material examinado: HAS 104195.

Microcystis wesenbergii (Komárek) Komárek in Kondrateva, Cvetenie vody, p. 13-42. 1968b. Basônimo: Diplocystis wesenbergii Komárek, in Komárek \& Ettl, Algologische Studien, p. 68. 1958.

(Figs. 14A, 19F)

Colônias microscópicas, esféricas, alongadas, lobadas, irregulares, clatradas, às vezes compostas por subcolônias, 20,0-69,0 $\mu \mathrm{m}$ diâm., 35,0-157,0 $\mu \mathrm{m}$ compr.; células dispostas irregularmente e próximas umas das outras; mucilagem homogênea, incolor, firme, margem espessa e evidente; células esféricas, 5,0-8,0 ㅆm diâm.; conteúdo celular verde-azulado; com aerótopos.

Os espécimes observados exibiram dimensões celulares que ampliam o intervalo referido para a espécie por Komárek \& Anagnostidis (1998) (4-7 $\mu$ m). Apesar dos organismos apresentarem diâmetros celulares que variam até valores que ultrapassam os limites citados para a espécie, esses foram identificados como $M$. wesenbergii por apresentarem as demais características exibidas pela espécie.

A espécie pode ser facilmente distinguida das demais do gênero por apresentar colônias lobadas e uma mucilagem bastante característica (homogênea, incolor, firme e com margem refringente).

No presente trabalho a espécie foi registrada apenas no plâncton da lagoa do Casamento.

Material examinado: HAS 104106. 


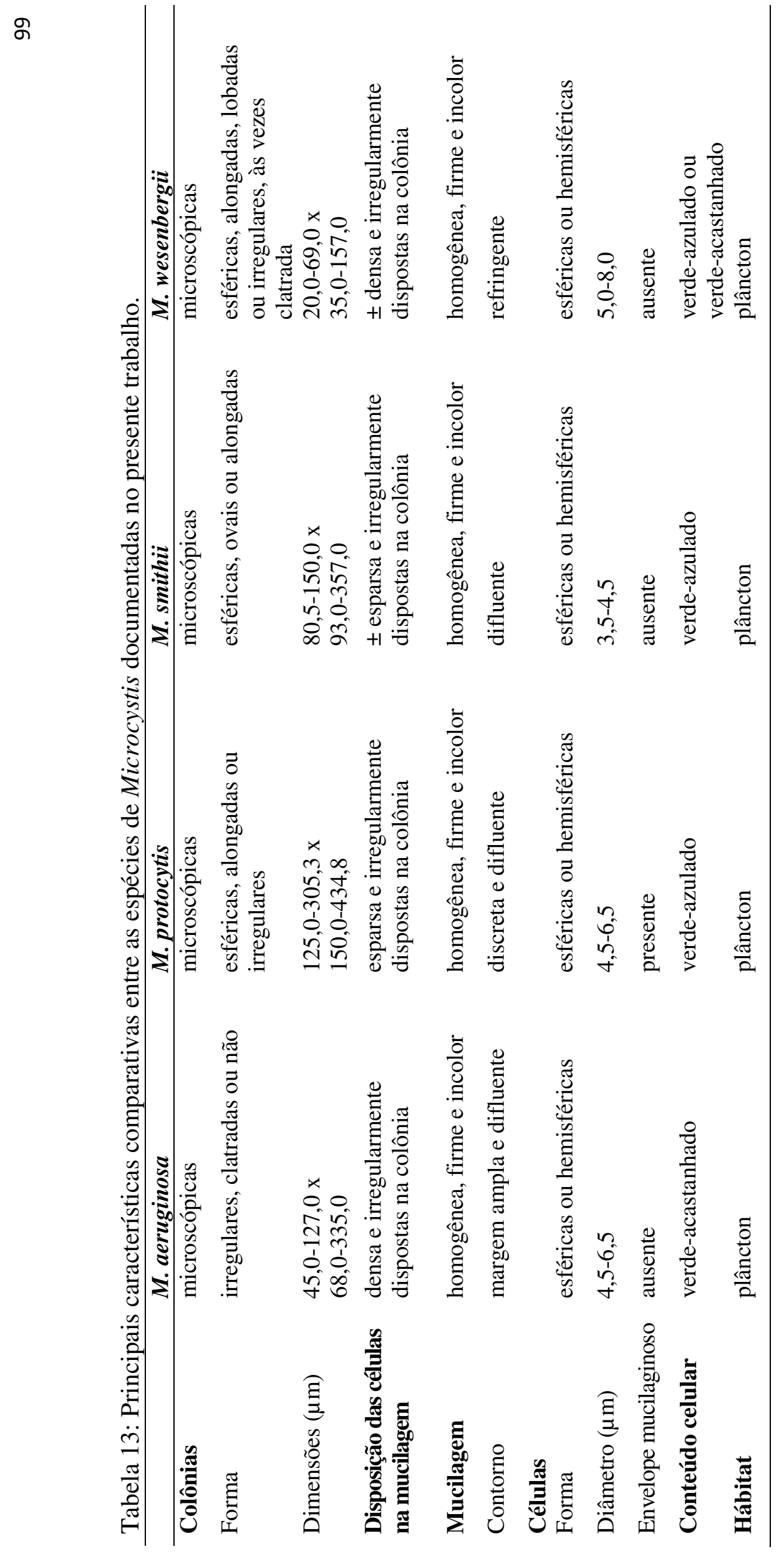




\section{CHROOCOCCACEAE Nägeli, 1849.}

A família engloba as cianobactérias que exibem colônias micro ou macroscópicas, às vezes formando "mats"; células solitárias ou em grupos irregulares, às vezes em pacotes; mucilagem incolor, firme ou difluente, homogênea ou lamelada, contorno normalmente evidente; células esféricas ou ovais; divisão celular por fissão binária em três ou mais planos em sucessivas gerações; células-filhas não atingem o tamanho e forma original antes da próxima divisão (KOMÁREK \& ANAGNOSTIDIS, 1998).

Chroococcaceae, segundo Komárek \& Anagnostidis (1998), é dividida em oito gêneros e, embora Hoffmann et al. (2005) também classifiquem os representantes da família em oito gêneros, as classificações apresentam diferenças. Para os primeiros autores, os gêneros que compõem Chroococcaceae são Asterocapsa, Chroococcus, Cyanokybus, Cyanosarcina, Cyanostylon, Gloeocapsopsis, Nephrococcus e Pseudocapsa, enquanto Hoffmann et al. (2005) classificaram Cyanostylon na família Entophysalidaceae, aceitam apenas as espécies que constituem Chroococcus subgen. Chroococcus e incluem algumas espécies do gênero Merismopedia, baseados em dados moleculares.

No presente estudo foi registrada a ocorrência de sete espécies pertencentes a apenas um gênero, Chroococcus.

\section{Chroococcus Nägeli, 1849.}

Basônimo: Chroococcus rufescens Nägeli, Neue Denkschr. Allg. Schweiz. Ges. Gesammten Naturwiss, v. 10, n. 7, p. 45. 1849.

Chroococcus é um gênero descrito a partir de uma espécie edáfica e caracteriza-se por apresentar células solitárias ou grupos de células dispostas irregularmente em uma mucilagem incolor ou amarelada, formando colônias microscópicas, esféricas, ovais, alongadas ou irregulares; células esféricas, ovais ou oblongas, quase sempre hemisféricas após a divisão, com ou sem envelope mucilaginoso; conteúdo celular homogêneo ou granuloso; aerótopos presentes em algumas espécies planctônicas; as células se dividem em três ou mais planos em sucessivas gerações e a reprodução se dá através da divisão celular e liberação de uma célula ou grupo de células (KOMÁREK \& ANAGNOSTIDIS, 1998).

Trata-se de um gênero morfologicamente variado. Segundo Komárek \& Hauer (2009), das mais de 120 espécies descritas no gênero, apenas cerca de 60 são bem delimitadas. 
O gênero é amplamente distribuído em ambientes de água doce, sendo encontrados com menor frequência em ambientes salinos. São principalmente metafíticos, mas também são encontrados em ambientes aerofíticos, termais e terrestres, bem como no plâncton cuja presença de aerótopos é facultativa nestas espécies (KOMÁREK \& HAUER, 2009).

Segundo Geitler (1942), a espécie-tipo de Chroococcus é C. turgidus (Kützing) Nägeli, no entanto, Komárek \& Anagnostidis (1998) consideram C. rufescens (Kützing) Nägeli como espécie-tipo que, embora pouco conhecida, apresenta características morfológicas que a sustentam neste gênero.

O gênero é dividido em dois subgêneros, Limnococcus e Chroococcus. O primeiro caracteriza-se por apresentar células dispostas esparsa e irregularmente em uma mucilagem amorfa e o segundo por exibir células solitárias ou em pequenos grupos delimitados por uma mucilagem firme, às vezes, lamelada e com margem evidente (KOMÁREK \& ANAGNOSTIDIS, 1998).

Segundo Hoffmann et al. (2005), dados moleculares indicam que os representantes do subgênero Limnococcus pertencem à família Merismopediaceae, enquanto as espécies do subgênero Chroococcus devem permanecer na família Chroococcaceae.

Joosten (2006) defende a idéia de que as espécies pertencentes ao subgênero Limnococcus podem ser tratadas como um gênero a parte, pois diferem das demais espécies pelo formato da colônia e pela disposição das células na mucilagem. $\mathrm{O}$ autor também comenta que um segundo grupo, composto por $C$. aphanocapsoides Skuja ex Joosten, $C$. microscopicus Komárková-Legnerová et Cronberg e C. batavus Joosten é ainda mais atípico e poderia ser excluído do subgênero Limnococcus.

No presente trabalho foram identificadas sete espécies de Chroococcus, cinco pertencentes a Chroococcus subgênero Limnococcus e duas ao subgênero Chroococcus.

\section{Chave para identificação das espécies encontradas}

1. Células solitárias ou em colônias de $2-4$ células ...................................................................2

1. Células em colônias com 8 células ou mais ............................................................................

2. Células com até $7,5 \mu \mathrm{m}$ diâm. ...................................................................... C. minutus

2. Células maiores que $8,0 \mu \mathrm{m}$ diâm. .............................................................. C. turgidus

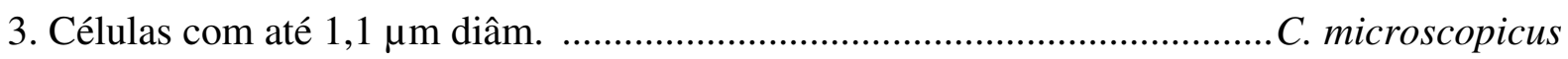

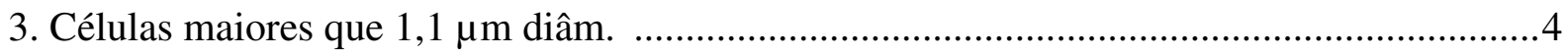

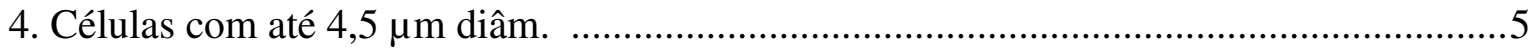

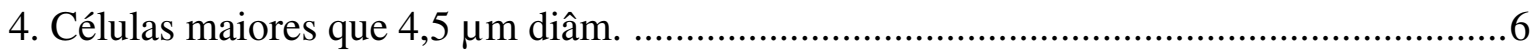


5. Células dispostas em grupos na colônia, 3,0-4,5 $\mu$ m diâm.

C. dispersus

5. Células dispostas regularmente na colônia, 2,4-3,3 $\mu \mathrm{m}$ diâm. C. minimus

6. Células distantes umas das outras, 5,3-7,5 $\mu \mathrm{m}$ diâm., envelope mucilaginoso inconspícuo C. distans

6. Células próximas umas das outras, 6,0-10,0 $\mu \mathrm{m}$ diâm., envelope mucilaginoso conspícuo C. limneticus

Chroococcus dispersus (Keissler) Lemmermann, Ark. Bot., v.2, n.2, p.102. 1904.

Basônimo: Chroococcus minor (Kützing) Nägeli var. dispersus Keissler, Verh. Zool.-bot. Ges. Wien., v. 52, p. 311. 1902.

(Fig. 14C)

Colônias microscópicas, alongadas ou irregulares, 62,5-71,7 $\mu \mathrm{m}$ diâm., 80,3-89,7 $\mu \mathrm{m}$ compr.; células arranjadas em pequenos grupos (4-16 células) distantes uns dos outros na colônia; mucilagem homogênea, firme, incolor, margem difluente; células esféricas ou hemisféricas após a divisão, 3,0-4,5 $\mu \mathrm{m}$ diâm., envelope mucilaginoso indistinto; conteúdo celular verde-azulado, homogêneo; sem aerótopos.

Chroococcus dispersus e C. minimus (Keissler) Lemmermann são espécies morfologicamente semelhantes, diferindo no diâmetro celular e na distribuição das células na colônia. Em C. dispersus as células encontram-se dispostas em pequenos grupos, distantes uns dos outros, sendo esta a principal característica que a distingue das demais espécies do gênero.

Considerando as características morfológicas diacríticas das espécies do gênero Chroococcus citadas na bibliografia especializada (KOMÁRKOVÁ-LEGNEROVÁ \& CRONBERG, 1994; KOMÁREK \& ANAGNOSTIDIS, 1998), as populações analisadas estão de acordo com as características referidas para C. dispersus.

Os espécimes encontrados foram registrados apenas no plâncton.

Material examinado: HAS 104343, HAS 104451. 
Chroococcus distans (G. M. Smith) Komárková-Legnerová et Cronberg, Algol. Studies, v. 72, p. 26-27. 1994.

Basônimo: Chroococcus limneticus Lermmermann var. distans G. M. Smith, Bull. Torrey bot. Cl., v. 43, p.481. 1916.

(Figs. 14D, 20D)

Colônias microscópicas, alongadas ou irregulares, 55,5-70,8 $\mu$ m diâm., 67,3-121,8 $\mu \mathrm{m}$ compr.; células dispostas esparsa e irregularmente na colônia; mucilagem homogênea, firme, incolor, margem difluente; células esféricas ou hemisféricas após a divisão, 5,3-7,5 $\mu \mathrm{m}$ diâm., envelope mucilaginoso indistinto; conteúdo celular verde-azulado, homogêneo; sem aerótopos.

As populações analisadas estão de acordo com as descritas na bibliografia especializada (KOMÁRKOVÁ-LEGNEROVÁ \& CRONBERG, 1994; KOMÁREK \& ANAGNOSTIDIS, 1998).

Chroococccus distans e C. limneticus Lemmermann são espécies morfologicamente muito próximas, diferindo apenas nas dimensões celulares e no padrão de distribuição das células na colônia.

Nas amostras analisadas, $C$. distans ocorreu normalmente junto com $C$. limneticus, e as características utilizadas para identificá-las foi arranjo das células na colônia, diâmetro celular que, embora ocorram sobreposições métricas, as células de $C$. distans são menores e apresentam-se dispostas mais distantes umas das outras, além de não exibirem envelope mucilaginoso. As colônias de $C$. distans são maiores que as de $C$. limneticus, fato também observado por Komárková-Legnerová \& Cronberg (1994).

As populações analisadas foram registradas tanto no plâncton quanto no metafíton.

Material examinado: HAS 104150, HAS 104343, HAS 104348, HAS 104352.

Chroococcus limneticus Lemmermann, Bot. Zbl., 76, p. 153. 1898.

(Figs. 15A-B, 20E)

Colônias microscópicas, ovais, alongadas ou irregulares, 40,0-60,0 $\mu \mathrm{m}$ diâm., 60,385,5 $\mu \mathrm{m}$ compr.; células dispostas irregularmente ou em grupos indistintos de 2-6 células na colônia; mucilagem homogênea, firme, incolor, margem difluente; células esféricas ou hemisféricas após a divisão, 6,0-10,5 $\mu \mathrm{m}$ diâm., envelope mucilaginoso usualmente distinto; conteúdo celular verde-azulado, homogêneo; sem aerótopos. 
As características morfológicas e métricas das populações analisadas estão de acordo com as referidas por Komárková-Legnerová \& Cronberg (1994), Komárek \& Anagnostidis (1998) e Werner (2002).

Chroococcus limneticus exibe uma ampla variação métrica (KOMÁREK \& ANAGNOSTIDIS, 1998) e populações com células pequenas podem ser comparadas a $C$. distans. Segundo Joosten (2006), colônias com características intermediárias entre $C$. limneticus e $C$. distans são muito comuns. As duas espécies foram registradas nos ambientes amostrados no presente trabalho e sua diferenciação baseou-se nas dimensões da colônia, das células e na presença ou ausência de envelope mucilaginoso. Analisando esses caracteres morfológicos, notou-se que as populações de C. limneticus exibiram colônias menores, diâmetros celulares maiores, embora com alguma sobreposição, e células com envelope mucilaginoso.

A espécie foi documentada somente para o plâncton.

Material examinado: HAS 104098, HAS 104103, HAS 104150, HAS 104153, HAS 104167, HAS 104343, HAS 104348, HAS 104351, HAS 104352, HAS 104376, HAS 104396.

Chroococcus microscopicus Komárková-Legnerová et Cronberg, Algol. Studies, v. 72, p. 28. 1994.

(Fig. 15F)

Colônias microscópicas e irregulares, 5,5-18,5 $\mu \mathrm{m}$ diâm., 6,5-30,0 $\mu \mathrm{m}$ compr.; células dispostas em grupos de 8, com arranjo cúbico e envoltos por mucilagem; mucilagem homogênea, firme, incolor, margem difluente; células esféricas ou hemisféricas após a divisão, 0,8-1,1 $\mu \mathrm{m}$ diâm.; conteúdo celular verde-azulado, homogêneo; sem aerótopos.

Chroococcus microscopicus é semelhante a C. aphanocapsoides Skuja principalmente pela distribuição das células na colônia, no entanto, as dimensões celulares de $C$. aphanocapsoides são maiores $(1,8-2,3 \mu \mathrm{m})$. Os espécimes analisados apresentaram dimensões celulares semelhantes às descritas para C. microscopicus (KOMÁRKOVÁ-LEGNEROVÁ \& CRONBERG, 1994).

A população observada raramente apresentou colônias bem desenvolvidas como as analisadas por Komárková-Legnerová \& Cronberg, 1994 e Joosten, 2006, no entanto as demais características exibidas estavam de acordo com as referidas para a espécie. Grande parte do material analisado era composta por colônias formadas por 1 a 3 grupos de células delimitadas por mucilagem com margem evidente. 
No presente estudo C. microscopicus foi observado apenas no plâncton da Lagoa do Capivari.

Material examinado: HAS 104343.

Chroococcus minimus (Keissler) Lemmermann, Ark. F. Bot., 2, p. 102. 1904.

Basônimo: Chroococcus minutus (Kützing) Nägeli var. minimus Keissler, Verh. Zool. Bot. Ges. Wien, p.394. 1901.

(Fig. 15C)

Colônias microscópicas, esféricas, ovais ou irregulares, 30,5-48,3 $\mu$ m diâm., 50,3-63,8 $\mu \mathrm{m}$ compr.; células dispostas mais ou menos regularmente; mucilagem homogênea, firme, incolor, margem difluente; células esféricas ou hemisféricas após a divisão, 2,4-3,3 $\mu \mathrm{m}$ diâm., envelope mucilaginoso usualmente distinto; conteúdo celular verde-azulado, homogêneo; sem aerótopos.

As populações registradas ocorreram tanto no plâncton quanto no metafíton.

Material examinado: HAS 104163, HAS 104416.

Chroococcus minutus (Kützing) Nägeli, Gatt. Einz. Algen., p. 46. 1849.

Basônimo: Protococcus minutus Kützing, Phycol. Germ., p. 168. 1843.

(Fig. 15E)

Células solitárias ou colônias microscópicas, ovais ou alongadas, com poucas células (2-8 células); mucilagem homogênea, firme, incolor, margem evidente, às vezes lamelada; células esféricas ou hemisféricas após a divisão, 5,0-7,5 $\mu \mathrm{m}$ diâm.; conteúdo celular verdeazulado, homogêneo ou granuloso; sem aerótopos.

Os espécimes observados estão de acordo com as características morfológicas e métricas referidas por Geitler (1932) e Komárek \& Anagnostidis (1998) para C. minutus.

Grande parte dos espécimes observados eram células solitárias ou colônias com duas células.

Chroococcus minor (Kützing) Nägeli é uma espécie muito semelhante a C. minutus, diferindo nas colônias e nas dimensões celulares, que são maiores em C. minutus.

As populações observadas foram registradas apenas no plâncton.

Material examinado: HAS 104352, HAS 104356. 
Chroococcus turgidus (Kützing) Nägeli, Gatt. Einz. Algen. P. 46. 1849.

Basônimo: Protococcus turgidus Kützing, Tab. Phycol. v. 1, p. 5. 1846.

(Figs. 15D, 20F)

Colônias microscópicas, ovais ou elípticas, com poucas células (2-4 células); mucilagem homogênea ou lamelada, firme, incolor, margem evidente; células esféricas ou hemisféricas após a divisão, 8,0-12,5 $\mu \mathrm{m}$ diâm., envelope mucilaginoso homogêneo ou lamelado, às vezes não evidente; conteúdo celular verde-azulado, homogêneo ou granuloso; sem aerótopos.

Considerando a bibliografia especializada (GEITLER, 1932; KOMÁREK \& ANAGNOSTIDIS, 1998), Chroococcus turgidus é uma espécie com ampla variação quanto ao número de células e aspecto da mucilagem da colônia. $C$. turgidus está entre as espécies que apresentam maior diâmetro celular no gênero. C. giganteus $\mathrm{W}$. West é uma das espécies morfologicamente mais próximas de C. turgidus, diferindo apenas no diâmetro celular [54-58 (65) $\mu \mathrm{m}]$.

Os espécimes observados apresentaram células com diâmetro celular reduzido, quando comparado com a ampla variação métrica descrita para a espécie, no entanto, foram identificados como $C$. turgidus por exibirem as características morfológicas e dimensões celulares próximas ao limite métrico inferior referidas para a espécie.

As populações registradas na área de estudo estavam presentes tanto no plâncton quanto no metafíton.

Material examinado: HAS 104202, HAS 104234, HAS 104135, HAS 104343, HAS 104451. 


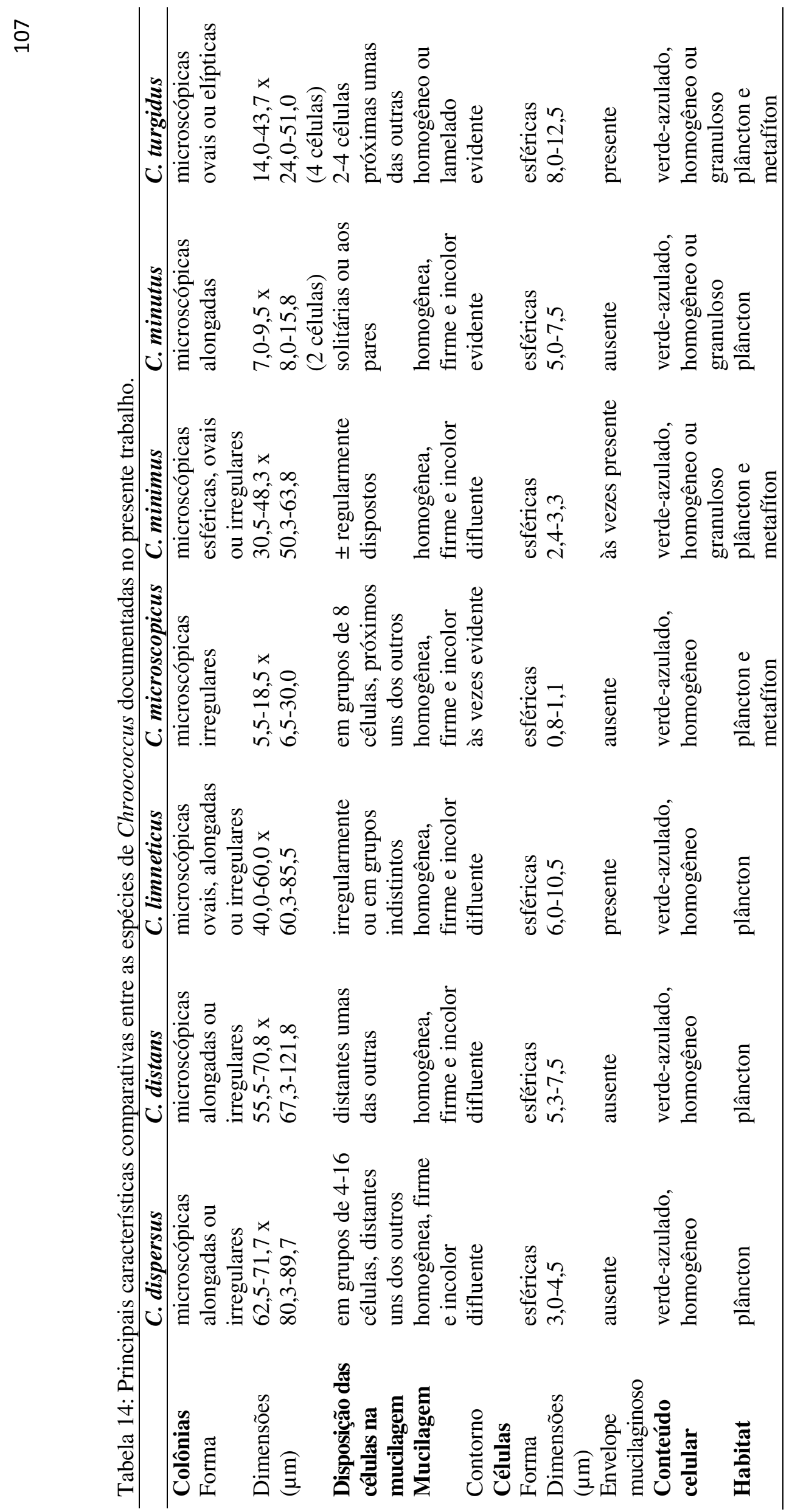




\section{OSCILLATORIALES}

A ordem Oscillatoriales é formada pelas cianobactérias filamentosas homocitadas que apresentam tilacoides dispostos radialmente ou irregularmente nas células. Os membros da ordem são caracterizados por desenvolver células com organização unisseriada, formando tricomas que podem ou não estar envolvidos por bainha mucilaginosa e não apresentam ramificações verdadeiras.

Segundo Gomont (1892) as cianobactérias filamentosas homocitadas pertencem à família Hormogonae, estando organizadas em duas tribos, Vaginariae e Lyngbyaea, que pertencem à subfamília Homocysteae. As tribos diferem entre si pelo tipo de bainha mucilaginosa e pelo número de tricomas por filamento. Geitler (1932), baseado em características morfológicas e métricas dos tricomas e filamentos e no hábitat, organizou as filamentosas homocitadas na família Oscillatoriaceae. De acordo com Anagnostidis \& Komárek (1988), a ordem Oscillatoriales incluiria todas as cianobactérias filamentosas homocitadas sem ramificações verdadeiras, cerca de 43 gêneros, que foram divididas em seis famílias (Borziaceae, Pseudanabaenaceae, Schizotrichaceae, Phormidiaceae, Oscillatoriaceae e Homeotrichaceae). Posteriormente, Komárek \& Anagnostidis (2005) organizaram a ordem Oscillatoriales também em seis famílias (Pseudanabaenaceae, Schizotrichaceae, Borziaceae, Phormidiaceae, Gomontiellaceae e Oscillatoriaceae), incluindo tanto espécies com tilacoides parietais como radialmente ou irregularmente dispostos nas células.

Em todas as classificações acima citadas, as cianobactérias filamentosas homocitadas eram reunidas em um grupo único, mas estudos moleculares vêm mostrando que esses arranjos taxonômicos não refletem a história evolutiva do grupo. Assim, a proposta de Hoffmann et al. (2005) divide as cianobactérias filamentosas homocitadas acordo, principalmente, com a disposição dos tilacoides na célula. Segundo os autores, a ordem compreende 32 gêneros, divididos em cinco famílias, Borziaceae (3), Phormidiaceae (18), Ammatoideaceae (2), Oscillatoriaceae (6) e Gomontiellaceae (3).

Posteriormente, Komárek (2006) inclui uma terceira família, Spirulinaceae, com três gêneros.

No presente estudo são registradas 21 espécies de Chroococcales, classificados nas famílias Phormidiaceae (quatro gêneros e 13 espécies) e Oscillatoriaceae (dois gêneros e oito espécies). 


\section{CHAVE PARA IDENTIFICAÇÃO DAS FAMÍLIAS ENCONTRADAS}

1. Células isodiamétricas Phormidiaceae

1. Células mais curtas que largas (discoides) Oscillatoriaceae

\section{PHORMIDIACEAE Nägeli, 1849}

A família Phormidiaceae caracteriza-se por desenvolver as seguintes características: tricomas solitários, isopolares ou heteropolares (em apenas uma subfamília), solitários ou formando tufos, com ou sem bainha mucilaginosa; bainha mucilaginosa delicada ou firme, espessa ou estreita, homogênea ou lamelada, geralmente incolor, raramente colorida, usualmente aberta, raramente fechada (Microcoleoideae), com um ou mais tricomas (Microcoleoideae); ramificações falsas presentes em algumas espécies que apresentam bainha mucilaginosa; tricomas cilíndricos, retos ou variavelmente espiralados, não constritos a constritos; células isodiamétricas ou levemente mais longas ou mais curtas que largas; células apicais, às vezes, com caliptra; com ou sem aerótopos; todas as células possuem capacidade de divisão (exceto as células apicais), atingindo o tamanho original antes da próxima divisão; reprodução através da fragmentação dos tricomas em hormogônios ou hormocitos, com a formação de necrídios (KOMÁREK \& ANAGNOSTIDIS, 2005).

Segundo Anagnostidis \& Komárek (1988), Phormidiaceae é dividida em três subfamílias, Phormidioideae, Microcoleoideae e Spirulinoideae, em função de características como presença ou ausência de bainha mucilaginosa, tricomas espiralados ou não e pelo número de tricomas por bainha.

Komárek \& Anagnostidis (2005) dividiram os 19 gêneros de Phormidiaceae em três subfamílias: Ammatoideoideae (3), que apresenta tricomas heteropolares, Microcoleoideae (3), com bainha mucilaginosa contendo dois ou mais tricomas e Phormidioideae (10), com bainha contendo apenas um tricoma.

No presente estudo foram identificadas 13 espécies de Phormidiaceae pertencentes a cinco gêneros: Microcoleus (2), Phormidium (8), Planktothrix (2) e Trichodesmium (1). 


\section{CHAVE DE IDENTIFICAÇÃO DAS SUBFAMÍLIAS ENCONTRADAS}

1. Bainha mucilaginosa, quando presente, com somente um tricoma. Phormidioideae

1. Bainha mucilaginosa com mais de um tricoma Microcoleoideae

Subfamília Microcoleoideae Hansgirg, 1892.

\section{Microcoleus Desmazières ex Gomont, 1892.}

Espécie-tipo: Microcoleus vaginatus (Vaucher) Gomont, Ann. Sci. Nat. Bot., Sér. 7, v. 16, p. 15. 1892.

O gênero Microcoleus é caracterizado por apresentar filamentos emaranhados ou solitários, normalmente aderidos a um substrato, não ramificados; bainha mucilaginosa larga, homogênea, raramente estriadas, incolor, firme, às vezes difluente, contendo mais de um tricoma; tricomas densamente agregados, organizados paralelamente na bainha mucilaginosa, não constritos ou levemente constritos, retos, usualmente atenuados em direção ao ápice; células cilíndricas, mais ou menos isodiamétricas; conteúdo celular granuloso; célula apical subcônica, às vezes capitada, raramente com caliptra; reprodução através da desintegração do tricoma ou pela formação de hormogônios (KOMÁREK \& ANAGNOSTIDIS,2005).

A maioria das espécies é bentônica ou terrestre, muitas delas sendo conhecidas de estuários e outros ambientes salinos.

No presente trabalho foram registradas duas espécies de Microcoleus, M. lacustris e M. subtorulosus.

\section{Chava de identificação das espécies encontradas}

1. Tricomas com 3,7-5,0 $\mu \mathrm{m}$ diâm. M. lacustris

1. Tricomas com 6,0-7,5 $\mu \mathrm{m}$ diâm. M. subtorulosus

Microcoleus lacustris (Rabenhorst) Farlow ex Gomont, Alg. Exs. Am. Bor. 227. 1877.

Basônimo: Chthonoblastus lacustris Rabenhorst, Krypt. Fl., v. 1, p. 85. 1863.

(Fig. 16A)

Filamentos solitários, flexuosos, ramificados ou não; bainha homogênea, firme, espessa, incolor; tricomas organizados em feixes paralelos ou levemente torcidos, 3 a 7 por bainha, distintamente constritos, 3,7-5,0 $\mu \mathrm{m}$ diâm.; células 1,3-2,8 vezes mais longas que 
largas, 5,0-11,0 $\mu \mathrm{m}$ compr.; conteúdo celular verde-azulado, granuloso; célula apical cilíndrico-arredondada ou cônico-arredondada, sem espessamento.

Os espécimes examinados concordam com as descrições de Microcoleus lacustris na literatura especializada (GOMONT, 1892; GEITLER, 1932; KOMÁREK \& ANAGNOSTIDIS, 2005). A única diferença entre o material observado e o descrito por esses autores é o comprimento celular. Na população analisada os valores registrados ampliam o limite métrico inferior referido para a espécie $(6,0-12,0 \mu \mathrm{m})$.

Embora a espécie seja considerada bentônica, os espécimes analisados foram observados apenas no plâncton de corpos d'água rasos e a ação dos ventos pode ter causado a remoção dos organismos bentônicos para a superfície da água.

Material examinado: HAS 104203, HAS 104427.

Microcoleus subtorulosus Gomont ex Gomont, Ann. Sci. nat. Sér. 7, v. 16, p. 360. 1892.

(Figs. 16B, 21A)

Filamentos solitários, flexuosos, não ramificados; bainha homogênea, firme, espessa, incolor; tricomas organizados em feixes paralelos, 1 a 8 por bainha, distintamente constritos, 6,0-7,5 $\mu \mathrm{m}$ diâm.; células 0,5-0,9 vez mais longas que largas, 4,0-7,2 (-8,0) $\mu \mathrm{m}$ compr.; conteúdo celular verde-azulado, granuloso; célula apical cilíndrico-arredondada ou cônicoarredondada, sem espessamento.

Os espécimes observados apresentaram características morfológicas e métricas de acordo com as descritas para a espécie (GOMONT, 1892; KOMÁREK \& ANAGNOSTIDIS, 2005).

Apesar de Microcoleus subtorulosus ser uma espécie com ampla distribuição (KOMÁREK \& ANAGNOSTIDIS, 2005), o registro de sua ocorrência no presente trabalho trata-se da primeira referência a espécie para o estado do Rio Grande do Sul.

A ocorrência de Microcoleus subtorulosus no Brasil foi registrada tanto em ambientes lóticos (BRANCO et al., 1999; BRANCO \& PEREIRA, 2002; PERES, 2007), como lênticos (SANT'ANNA \& AZEVEDO, 1995). No presente trabalho foram amostrados apenas ambientes lênticos, e, embora seja uma espécie típica do bentos, foi observados apenas no plâncton. A sua presença no plâncton pode ser explicada pelo fato de ocorrerem em lagoas rasas, cuja ação dos ventos pode remover a comunidade bentônica.

Material examinado: HAS 104171, HAS 104172. 
Tabela 15: Principais características comparativas entre as espécies de Microcoleus documentadas no presente trabalho.

\begin{tabular}{lll}
\hline & M. lacustris & M. subtorulosus \\
\hline Filamentos & $\begin{array}{l}\text { solitários, flexuosos, ramificados } \\
\text { ou } \\
\text { não ramificados }\end{array}$ & $\begin{array}{l}\text { solitários, flexuosos, } \\
\text { não ramificados }\end{array}$ \\
$\begin{array}{l}\text { Birme, espessa, incolor } \\
\mathrm{N}^{\circ} \text { de tricomas }\end{array}$ & $\begin{array}{l}\text { firme, espessa, incolor } \\
\text { Tricomas }\end{array}$ & $1-8$ \\
Diâmetro $(\mu \mathrm{m})$ & constritos & constritos \\
Células apicais & $3,7-5,0$ & $6,0-7,5$ \\
& cilíndrico-arredondada ou & cilíndrico-arredondada ou \\
Espessamento & cônico-arredondada & ausente \\
Intermedondada \\
Comprimento \\
RC/L
\end{tabular}

Subfamília Phormidioideae Anagnostidis et Komárek, 1986.

\section{CHAVE PARA IDENTIFICAÇÃO DOS GÊNEROS ENCONTRADOS}

1. Tricomas em fascículos Trichodesmium

1. Tricomas não formando fascículos .2

2. Células com aerótopos Planktothrix

2. Células sem aerótopos Phormidium

\section{Phormidium Kützing ex Gomont, 1892.}

Espécie-tipo: Phormidium lucidum Kützing ex Gomont, Ann. Sci. nat., Sér. 7, v. 16, p. 179. 1892.

Segundo Gomont (1892), Geitler (1932) e Desikachary (1959), Phormidium é um gênero caracterizado por desenvolver talos gelatinosos prostrados ou flutuantes na água, formados por aglomerados de filamentos; bainha mucilaginosa firme, fina, incolor; tricomas cilíndricos, constritos ou não, atenuados ou não, retos ou flexuosos, capitados ou não; célula apical com ou sem caliptra.

Posteriormente, Anagnostidis \& Komárek (1988) classificaram as espécies que compunham o gênero baseado nas seguintes características: tricomas cilíndricos, retos, flexuosos ou levemente a intensamente espiralados, não constritos a constritos; habilidade de 
formar bainha mucilaginosa, quando sob determinadas condições ambientais; bainha mucilaginosa firme, não lamelada; tricomas móveis dentro da bainha mucilaginosa ou sem bainha, sem ramificações falsas; células isodiamétricas ou mais curtas ou longas que largas; sem aerótopos; reprodução através da fragmentação do tricomas, formando hormogônios com auxílio de necrídios.

De acordo com eles, o gênero é dividido em quatro subgêneros, Geitlerinema, Gomontinema, Hansgirgia e Phormidium, principalmente com base na presença ou ausência de bainha mucilaginosa e no tipo de talo.

Segundo Anagnostidis \& Komárek (1988), em Geitlerinema a bainha ocorre excepcionalmente, em Gomontinema, a sua presença é facultativa e em Phormidium e Hansgirgia a bainha mucilaginosa normalmente está presente. Anagnostidis (1989) elevou o subgênero Geitlerinema ao nível de gênero, permanecendo Phormidium com apenas três subgêneros.

Komárek \& Anagnostidis (2005) definem como Phormidium, as cianobactérias que desenvolvem talos gelatinosos ou membranáceos, aderidos a um substrato ou flutuantes na água; filamentos variavelmente curvos, sem falsas ramificações; bainha mucilaginosa facultativa, firme ou delicada, usualmente incolor, não lamemada; tricomas cilíndricos, retos, flexuosos ou leve a fortemente ondulados, não constritos a constritos; células isodiamétricas ou mais longas ou curtas que largas; sem aerótopos; célula apical cônica, atenuada ou arredondada, com ou sem caliptra; reprodução através da desintegração do tricoma em hormogônios longo ou curtos, usualmente com formação de necrídios.

O gênero apresenta ampla distribuição e ocorre nos mais variados ambientes. Normalmente os organismos são encontrados formando "mats", em diferentes substratos aerofíticos e aquáticos, lênticos ou lóticos (solos, rochas úmidas, poças, plantas aquáticas). Podem ser encontrados em ambientes extremos, como fontes termais, desertos, entre outros, sendo raramente encontrados como filamentos solitários.

Komárek \& Anagnostidis (2005) consideram Phormidium um dos gêneros taxonomicamente mais complexos entre as cianobactérias e com maior número de morfoespécies descritas e dividem-no em oito grupos de acordo com a morfologia da região apical dos tricomas.

Grupo I - tricomas curtos ou gradualmente atenuados no ápice; células apicais pontiagudas, às vezes, curvas, sem caliptra nem espessamento;

Grupo II - tricomas gradualmente atenuados no ápice; células apicais distintamente atenuadas e arredondadas, sem caliptra; 
Grupo III - tricomas abruptamente atenuados e com ápices frequentemente curvos; células apicais levemente cônico-arredondadas ou quase cilíndricas e arredondadas, sem caliptra, com ou sem espessamento;

Grupo IV - tricomas usualmente cilíndricos até o ápice; células apicais distintamente cônicas, sem caliptra nem espessamento;

Grupo V - tricomas cilíndricos em todo o seu comprimento; células apicais largamente arredondadas, sem caliptra, às vezes, com espessamento;

Grupo VI - tricomas abruptamente atenuados no ápice; células apicais mais ou menos esféricas e capitadas;

Grupo VII - tricomas abrupta ou gradualmente atenuados no ápice; células apicais com caliptra;

Grupo VIII - tricomas cilíndricos com células distintamente mais curtas que largas, abruptamente atenuados no ápice; células apicais com caliptra ou com espessamento.

No presente estudo foram identificadas oito espécies de Phormidium que pertencem aos grupos III, V e VII.

\section{Chave para identificação das espécies encontradas}

1. Tricomas retos e não atenuados no ápice ..........................................................................2

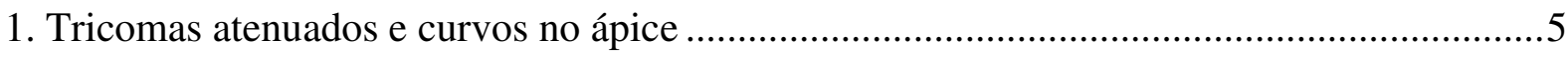

2. Tricomas não constrito, com bainha mucilaginosa ................................ P. aerugineo-caeruleum

2. Tricoma não constritos ou constritos, sem bainha mucilaginosa ............................................ 3

3. Tricomas até 4,5 $\mu \mathrm{m}$ diâm., não constritos, grânulos distintos nos septos transversais P. granulatum

3. Tricomas maiores que 4,5 $\mu \mathrm{m}$ diâm., tricomas não constritos ou constritos, septos não granulosos ou finamente granulosos.

4. Células isodiamétricas a mais longas que largas, septos não granulosos . P. hamelii

4. Células isodiamétricas a mais curtas que largas, septos finamente granulosos P. tergestinum

5. Célula apical capitada .6

5. Célula apical não capitada .7

6. Tricomas 3,5-4,0 $\mu \mathrm{m}$ diâm. P. amoenum

6. Tricomas 4,5-6,0 $\mu \mathrm{m}$ diâm. P. autumnale

7. Tricomas 4,5-6,5 $\mu \mathrm{m}$ diâm. .P. formosum

7. Tricomas 6,5-7,5 $\mu \mathrm{m}$ diâm. P. chalybeum 
Phormidium aerugineo-caeruleum (Gomont) Anagnostidis et Komárek, Algolog. Stud., v.50-53, p. 407. 1988.

Basônimo: Lyngbya aerugineo-caerulea Gomont, Ann. Sci. Nat. Bot., Sér. 7, v. 16, p. 146. 1892.

(Figs. 16E, 21B)

Filamentos solitários, retos ou flexuosos, 5,6-8,0 $\mu \mathrm{m}$ diâm.; bainha mucilaginosa fina, firme, homogênea, incolor; tricomas não atenuados, não constritos, 4,0-7,0 $\mu \mathrm{m}$ diâm.; células 0,4-1,3 vez mais longas que largas, 3,0-7,0 $\mu \mathrm{m}$ compr.; conteúdo celular verde-azulado, homogêneo; septos granulosos ou não; célula apical cilíndrico-arredondada, sem espessamento.

Os espécimes observados apresentaram características morfológicas e métricas que estão de acordo com a descrição original da espécie (GOMONT, 1892), exceto pelas medidas de diâmetro do tricoma, que ampliaram o intervalo referido pelo autor (4,0-6,0 $\mu \mathrm{m})$. Valores maiores para o diâmetro do tricoma também foram observados em populações brasileiras estudadas por Sant'Anna \& Azevedo (1995) e por Branco et al. (1999).

Phormidium aerugineo-caeruleum é amplamente distribuída tendo sido registrada em diversos tipos de hábitats (KOMÁREK \& ANAGNOSTIDIS, 2005). A toxicidade da espécie foi analisada por Teneva et al. (2003), que relataram a produção de neurotoxinas e hepatotoxinas.

Embora P. aerugineo-caeruleum seja conhecido por ser, principalmente, bentônico e perifítico, no presente estudo, a espécie foi registrada no plâncton e no metafíton e trata-se do primeiro relato desta para o estado do Rio Grande do Sul.

Material examinado: HAS 104112, HAS 104213, HAS 104242, HAS 104369, HAS 104381, HAS 104386, HAS 104391.

Phormidium amoenum Kützing ex Anagnostidis et Komárek, Algolog. Stud., v. 50-53, p. 404. 1988.

(Fig. 16D)

Tricomas solitários, retos ou flexuosos, curvos e levemente atenuados no ápice, não constritos, 3,5-4,0 $\mu \mathrm{m}$ diâm.; células 0,5-1,0 vez mais longas que largas, 2,4-4,0 $\mu \mathrm{m}$ compr.; conteúdo celular verde-azulado, homogêneo; septos granulosos; célula apical mais longa que as demais, 3,3-4,5 $\mu \mathrm{m}$ compr., capitada, com caliptra cônica. 
Os espécimes observados estão de acordo com as descrições referidas para Phormidium amoenum pela literatura consultada (GOMONT, 1892; GEITLER, 1932; KOMÁREK \& ANAGNOSTIDIS, 2005).

Phormidium amoenum e P. autumnale (Agardh) Trevisan ex Gomont podem ser confundidas por apresentarem morfologia semelhante. Estas duas espécies possuem tricomas com ápices atenuados, com caliptra e curvos. Embora os valores referidos para o diâmetro de seus tricomas se sobreponham, $P$. autumnale possui tricomas mais largos (4,0-7,0 $\mu \mathrm{m})$. Os espécimes registrados foram identificados como $P$. amoenum por terem apresentado diâmetro com valores inferiores aos citados para $P$. autumnale.

Nos ambientes amostrados, $P$. amoenum foi documentado apenas no plâncton e representa o primeiro registro de ocorrência da espécie para o Rio Grande do Sul.

Material examinado: HAS 104171, HAS 104203.

Phormidium autumnale (Agardh) Trevisan ex Gomont, Ann. Sci. nat. Sér. 7, v. 16, p. 187. 1892.

(Fig. 16C)

Tricomas solitários, retos ou flexuosos, curvos e fortemente atenuados no ápice, não constritos ou levemente constritos, 4,5-6,0 $\mu \mathrm{m}$ diâm.; células 0,5-1,0 vezes mais longas que largas, 2,0-5,0 $\mu \mathrm{m}$ compr.; conteúdo celular verde-azulado, homogêneo; septos granulosos; célula apical mais longa que as demais, 4,0-5,5 $\mu \mathrm{m}$ compr., capitada, com caliptra arredondada ou truncada.

Phormidium autumnale é conhecida por ser, principalmente, perifítica ou bentônica, sendo observada em todo o mundo e em diversos tipos de ambientes. Apesar dos espécimes analisados, no presente estudo, terem sido documentados apenas no plâncton, foram identificados como $P$. autumnale por exibirem características morfológicas e métricas que estão de acordo coma as referidas para a espécie (GOMONT, 1892; KOMÁREK \& ANAGNOSTIDIS, 2005).

Como comentado anteriormente, a população identificada como $P$. autumnale foi diferenciada de $P$. amoenum a partir o diâmetro do tricoma, além do fato de que $P$. autumnale apresentou caliptra arredondada, enquanto P. amoenum exibiu caliptra cônica.

Material examinado: HAS 104124, HAS 104142, HAS 104171, HAS 104356, HAS 104369. 
Phormodium chalybeum (Mertens ex Gomont) Anagnostidis et Komárek, Algolog. Stud., v. 50-53, p. 405. 1988.

Basônimo: Oscillatoria chalyea Mertens ex Gomont, Ann. Sci. nat., Sér. 7, v. 16, p. 232. 1892.

(Fig. 16F)

Tricomas solitários, retos ou flexuosos, levemente atenuados e curvos no ápice, distintamente constritos, 6,5-7,5 $\mu \mathrm{m}$ diâm.; células 0,4-0,9 vez mais longas que largas, 3,5-6,5 $\mu \mathrm{m}$ compr.; conteúdo celular verde-azulado, homogêneo; septos não granulosos; célula apical cilíndrico-arredondada, às vezes curva, não capitada, sem espessamento.

Os espécimes estudados apresentaram os limites métricos inferiores do diâmetro do tricoma menores que os referidos por Gomont (1892), no entanto estão de acordo com os apresentados por Prescott (1970). As demais características métricas, como comprimento celular e relação entre comprimento e largura celulares estão de acordo com Gomont (1892) e com Komárek \& Anagnostidis (2005). Embora a população analisada tenha apresentado variação, quanto ao ápice do tricoma, a maioria exibiu célula apical cilíndrico-arredondada, levemente atenuada e curva, características da espécie.

Embora $P$. chalybeum seja uma espécie relatada principalmente no perifíton, no presente estudo, foi observada apenas no plâncton do banhado dos Gateados. Isso pode ser explicado pelo fato de que o referido banhado trata-se de um ambiente raso, sujeito ao vento, que pode ter sido responsável pela remoção dos organismos para a superfície da água.

Material examinado: HAS 104366.

Phormidium formosum (Bory ex Gomont) Anagnostidis et Komárek, Algolog. Stud., v. 5053, p. 405.1988.

Basônimo: Oscillatoria formosa Bory ex Gomont, Ann. Sci. nat., Sér. 7, v. 16, p. 230. 1892.

(Figs. 17A, 21C)

Tricomas solitários, retos ou flexuosos, levemente atenuados e curvos no ápice, levemente constritos, 4,5-6,5 $\mu \mathrm{m}$ diâm.; células 0,4-1,1 vezes mais longas que largas, 2,8-5,8 $\mu \mathrm{m}$ compr.; conteúdo celular verde-azulado, homogêneo; septos não granulosos ou finamente granulosos; célula apical cônico-arredondada, não capitada, sem espessamento.

Phormidium formosum é de uma espécie que exibe ampla distribuição, sendo considerada cosmopolita. É conhecida por ser, principalmente, bentônica, sendo relatada em ambientes lênticos e lóticos. Trata-se de uma espécie potencialmente produtora de homoanatoxina-a (LILLEHEIL et al., 1996; BAKER et al., 2001). 
Segundo Komárek \& Anagnostidis (2005), esta espécie pode ser confundida com Phormidium breve (Kützing ex Gomont) Anagnostidis et Komárek, pois ambas apresentam tricomas com ápice atenuado e curvo e diâmetros com valores que se sobrepõem. Ambas apresentam ampla distribuição, no entanto, $P$. breve apresenta células mais curtas (1,5-3,0 $\mu \mathrm{m})$ que as observadas no presente estudo.

Desta forma, os espécimes analisados estão de acordo com as características referidas para $P$. formosum por Gomont (1892). Segundo Komárek \& Anagnostidis (2005), os tricomas de $P$. formosum formam talos, mas no presente estudo, foram observados apenas tricomas solitários, fato também observado por Guarrera et al. (1995), em populações argentinas.

Nos ambientes amostrados, $P$. formosum foi documentado tanto no plâncton quanto no metafíton.

Material examinado: HAS 104092, HAS 104124, HAS 104134, HAS 104171, HAS 104174, HAS 104178, HAS 104179, HAS 104180, HAS 104234, HAS 104369, HÁS 104391, HAS 104399, HAS 104425, HAS 104427, HAS 104449, HAS 104450.

Phormidium granulatum (Gardner) Anagnotidis, Preslia, v. 73, p. 370. 2001.

Basônimo: Oscillatoria granulata Gardner, Mem. N. Y. bot. Gdn. New York, v. 7, p. 37. 1927.

(Figs. 17B, 21D)

Tricomas solitários, retos ou flexuosos, não atenuados, não constritos ou levemente constritos, 3,0-4,5 $\mu \mathrm{m}$ diâm.; células 0,7-1,0 vez mais longas que largas, 2,5-5,0 $\mu \mathrm{m}$ compr.; conteúdo celular verde-azulado, homogêneo; septos com 2-4 grânulos distintos; célula apical cilíndrico-arredondada, não capitada, sem espessamento.

Os espécimes analisados estão de acordo com a descrição original da espécie (GARDNER, 1927) que foi descrita a partir de material proveniente da Costa Rica e é considerada uma espécie com ampla distribuição, tendo sido observada em regiões tropicais e temperadas.

Phormidium granulatum pode ser confundida com $P$. tergestinum (Kützing) Anagnostidis et Komárek. Ambas apresentam tricomas retos, não atenuados, não constritos, com septos com grânulos. No entanto, os grânulos observados nos septos de P. granulatum são conspícuos e em pequeno número (1-5 grânulos), enquanto $P$. tergestinum apresenta septos com diminutos e numerosos grânulos (KOMÁREK \& ANAGNOSTIDIS, 2005).

No presente estudo, as populações foram observadas tanto no plâncton como no metafíton e representam o primeiro registro da espécie para o estado do Rio Grande do Sul. 
Material examinado: HAS 104163, HAS 104195, HAS 104213, HAS 104234, HAS 104369, HAS 104391, HAS 104442, HAS 104451, HAS 104455.

Phormidium hamelii (Frémy) Anagnostidis et Komárek, Algolog. Stud., v. 50-53, p. 405. 1988.

Basônimo: Oscillatoria hamelii Frémy, Arch. Bot. Mém. Caen, v. 3, p. 194. 1930.

(Fig. 17C)

Tricomas solitários, retos ou flexuosos, não atenuados, distintamente constritos, 4,56,0 $\mu \mathrm{m}$ diâm.; células 0,8-1,5 vez mais longas que largas, 4,5-7,5 $\mu \mathrm{m}$ compr.; conteúdo celular verde-azulado, homogêneo; septos não granulosos; célula apical cilíndricoarredondada, não capitada, sem espessamento.

Os espécimes observados apresentam características morfológicas e métricas de acordo com as descritas para P. hamelii por Frémy (1930).

Phormidium hamelii foi descrita a partir de material proveniente da França, mas já foi observado em regiões tropicais (FRÉMY, 1930; COMPÈRE, 1974; NEVES, 1983; SENNA, 1982; SANT'ANNA et al. 1989; WERNER\& ROSA, 1992).

No Rio Grande do Sul, a ocorrência da espécie já foi relatada por Werner e Rosa (1992). P. hamelii é considerada uma espécie bentônica, no entanto, no presente estudo, foi observada apenas no plâncton.

Material examinado: HAS 104167, HAS 104391.

Phormidium tergestinum (Kützing) Anagnostidis et Komárek, Algolog. Stud., v. 50-53, p. 406. 1988.

Basônimo: Oscillatoria tergestina Kützing, Alg. Aq. Dulc. Germ., v. 7, p. 34. 1836.

(Figs. 17D, 21E)

Tricomas solitários, retos ou flexuosos, não atenuados, não constritos, levemente ou distintamente constritos, 4,8-7,5 $\mu \mathrm{m}$ diâm.; células 0,4-1,0 vez mais longas que largas, 3,0-6,5 $\mu \mathrm{m}$ compr.; conteúdo celular verde-azulado, homogêneo; septos granulosos; célula apical cilíndrico-arredondada, não capitada, sem espessamento.

Phormidium tergestinum é considerada uma espécie perifítica e de ampla distribuição, exibindo grande variação morfológica. Segundo Komárek \& Anagnostidis (2005), o grande número de morfotipos indica que se trata de uma espécie coletiva e que precisa ser revisada.

Os espécimes observados apresentaram características morfométricas de acordo com as descritas para a espécie por Komárek \& Anagnostidis (2005). 
No presente estudo foram observadas populações de P. tergestinum e P. granulatum. Ambas apresentam morfologia semelhante, no entanto, os espécimes identificados como $P$. granulatum foram diferenciados de P. tergestinum por apresentarem tricomas levemente menores em diâmetro $(3,0-4,5 \mu \mathrm{m})$ e septos com grânulos conspícuos e em menor número, enquanto $P$. tergestinum exibiu septos com numerosos grânulos e estes, inconspícuos.

Material examinado: HAS 104092, HAS 104117, HAS 104124, HAS 104167, HAS 104178, HAS 104179, HAS 104180, HAS 104203, HAS 104227, HAS 104230, HAS 104232, HAS 104234, HAS 104 235, HAS 104366, HAS 104369, HAS 104381, HAS 104386, HAS 104391, HAS 104392, HAS 104394, HAS 104402, HAS 104445, HAS 104450. 


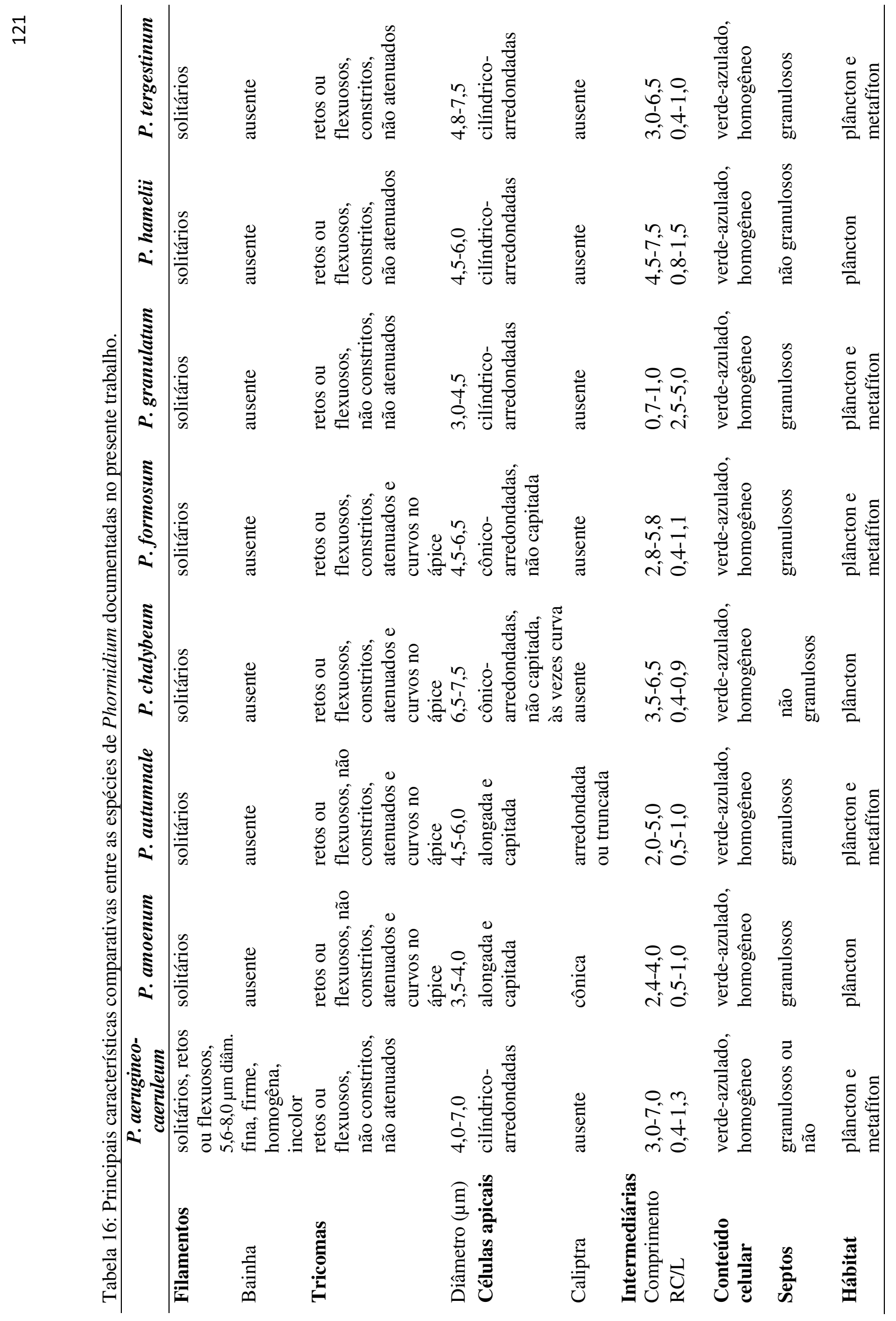




\section{Planktothrix Anagnostidis et Komárek, 1988.}

Espécie-tipo: Planktothrix agardhii (Gomont) Anagnostidis et Komárek, Algolog. Stud., v. 50-53, p. 416. 1988.

O gênero Planktothrix engloba as Phormidiaceae com tricomas solitários, planctônicos ou raramente metafíticos, retos ou curvos, cilíndricos, não constritos ou constritos, não a levemente atenuados no ápice, sem ramificações; bainha mucilaginosa usualmente ausente; células cilíndricas, geralmente mais curtas que largas a isodiamétricas; aerótopos obrigatoriamente distribuídos por toda a célula; células apicais cilíndrico-arredondadas ou cônico-atenuadas, às vezes, com caliptra; reprodução pela desintegração do tricoma em hormocitos, com auxílio de necrídios.

Quase todas as espécies são planctônicas e algumas delas podem causar florações, principalmente em corpos d'água mesotróficos a hipereutróficos. Apenas uma espécie, $P$. cryptovaginata (Skorbatov) Anagnostidis et Komárek, cresce no metafíton de corpos d'água não poluídos e entre plantas aquáticas (KOMÁREK \& KOMÁRKOVÁ, 2004). Duas espécies apresentam distribuição cosmopolita, ocorrendo principalmente sob condições ecológicas específicas, e apenas outras duas espécies são características de regiões tropicais (KOMÁREK \& HAUER, 2009).

Planktothrix, juntamente com Planktothricoides e Trichodesmium, são os únicos gêneros de Phormidiaceae que apresentam aerótopos. Trichodesmium diferencia-se de Planktothrix por desenvolver tricomas organizados paralelamente, formando feixes, enquanto Planktothricoides dintingui-se de Planktothrix por apresentar tricomas fortemente atenuados e aerótopos distribuídos na periferia da célula e tricomas fortemente atenuados.

No presente estudo foram registradas duas espécies de Planktothrix, P. agardhii e $P$. isothrix.

\section{Chava de identificação das espécies encontradas}

1. Tricomas atenuados no ápice P. agardhii

1. Tricomas não atenuados

P. isothrix 
Planktothrix agardhii (Gomont) Anagnostidis et Komárek Algolog. Stud., v. 50-53, p. 416. 1988.

Basônimo: Oscillatoria agardhii Gomont, Ann. Sci. nat., Sér. 7, v. 16, p. 205.1892.

(Fig. 17E)

Tricomas solitários, retos ou flexuosos, gradualmente atenuados no ápice, não ou levemente constritos, 4,8-6,0 $\mu \mathrm{m}$ diâm.; células 0,5-1,0 vez mais longas que largas, 2,1-5,0 $\mu \mathrm{m}$ compr.; conteúdo celular verde-azulado; com numerosos aerótopos; célula apical atenuada, às vezes, alongadas, caliptra triangular.

Os espécimes analisados concordam com os descritos na literatura (GOMONT, 1892; KOMÁREK \& KOMÁRKOVÁ, 2004; KOMÁREK \& ANAGNOSTIDIS, 2005).

Planktothrix agardhii pode ser confundida com P. pseudagardhii Sudda et Watanabe, pois ambas apresentam tricomas com diâmetros que se sobrepõem, atenuados no ápice e células apicais com caliptra. No entanto, em P. agardhii, o tricoma é gradualmente atenuado e a célula apical apresenta caliptra triangular e, em $P$. pseudagardhii, o tricoma é levemente atenuado e célula apical apresenta uma caliptra pequena (KOMÁREK \& KOMÁRKOVÁ, 2004).

Essa espécie é cosmopolita, largamente distribuída em corpos d'água mesoeutróficos a eutróficos, com exceção das regiões subpolares (KOMÁREK \& KOMÁRKOVÁLEGNEROVÁ, 2002). Está geralmente presente nas comunidades planctônicas, já tendo sido relatada formando florações (BRIAND et al., 2002; ERHARD et al., 1998; BUCKA \& WILK-WOZNIAK, 2005), muitas delas tóxicas, pois a espécie é potencialmente produtora de microcistina (ERHARD et al., 1998; FASTNER et al., 1999; YÉPRÉMIAN et al., 2007). Apesar da ocorrência em águas eutróficas, sua presença não indica necessariamente um ambiente poluído.

No presente estudo, P. agardhii foi observada apenas na zona pelágica da lagoa do Capivari.

Material examinado: HAS 104343.

Planktothrix isothrix (Skuja) Komárek et Komárková, Czech Phycol., v. 4, p. 14. 2004.

Basônimo: Oscillatoria agardhii var. isothrix Skuja, Symb. bot. Upsal., v. 9, n. 3, p. 49. 1948.

(Figs. 17F, 21F)

Tricomas solitários, retos ou flexuosos, não atenuados, não constritos, 4,0-10,0 $\mu \mathrm{m}$ diâm.; células 0,3-1,0 vez mais longas que largas, 2,0-5,0 $\mu \mathrm{m}$ compr.; conteúdo celular verde- 
acastanhado,às vezes, com grânulos nos septos; numerosos aerótopos; célula apical cilíndricoarredondada, sem espessamento.

Os caracteres morfológicos e métricos dos espécimes estudados estão de acordo com os descritos por Komárek \& Komárková (2004).

Segundo Komárek \& Anagnostidis (2005), P. isothrix é uma espécie primeiramente bentônica, podendo também fazer parte do plâncton. Ocorre em lagos eutróficos a hipereutróficos, formando florações tanto em regiões tropicais como temperadas (DAVIS et al., 2003; STEFANIAK et al., 2005; HALSTVEDT et al., 2007; PÉREZ et al., 2009).

Planktothrix isothrix vem causando problemas de florações durante os meses de verão no lago Guaíba (Porto Alegre, RS) desde 2003, como consequência da eutrofização do lago.

Os espécimes foram encontrados tanto no plâncton como no metafíton.

Material examinado: HAS 104124, HAS 104163, HAS 104167, HAS 104174, HAS 104179, HAS 104195, HAS 104203, HAS 104207, HAS 104234, HAS 104391.

Tabela 17: Principais características comparativas entre as espécies de Planktothrix documentadas no presente trabalho.

\begin{tabular}{|c|c|c|}
\hline & P. agardhii & P. isothrix \\
\hline Tricomas & $\begin{array}{l}\text { retos ou flexuosos, levemente } \\
\text { atenuados, não constritos a } \\
\text { levemente constritos }\end{array}$ & $\begin{array}{l}\text { retos ou flexuosos, não } \\
\text { atenuados, não constritos }\end{array}$ \\
\hline Diâmetro $(\mu \mathrm{m})$ & $4,8-6,0$ & $4,0-10,0$ \\
\hline $\begin{array}{l}\text { Células apicais } \\
\text { Caliptra }\end{array}$ & $\begin{array}{l}\text { atenuada, às vezes alongadas } \\
\text { triangular }\end{array}$ & $\begin{array}{l}\text { cilíndrico-arredondada } \\
\text { ausente }\end{array}$ \\
\hline $\begin{array}{l}\text { Intermediárias } \\
\text { Comprimento } \\
\mathrm{RC} / \mathrm{L}\end{array}$ & $\begin{array}{l}2,1-5,0 \\
0,5-1,0\end{array}$ & $\begin{array}{l}2,0-5,0 \\
0,3-1,0\end{array}$ \\
\hline $\begin{array}{l}\text { Conteúdo celular } \\
\text { Hábitat }\end{array}$ & $\begin{array}{l}\text { verde-acastanhado, } \\
\text { plâncton }\end{array}$ & $\begin{array}{l}\text { verde-acastanhado } \\
\text { plâncton }\end{array}$ \\
\hline
\end{tabular}

\section{Trichodesmium Ehrenberg ex Gomont, 1892.}

Espécie-tipo: Trichodesmium erythraeum Ehrenberg ex Gomont, Ann. Sci. Nat. Bot., Sér. 7, v. 16, p. 193. 1892.

O gênero Trichodesmium caracteriza-se por apresentar tricomas formando feixes, dipostos paralela ou radialmente, unidos por mucilagem difluente; tricomas sem bainha mucilaginosa, retos ou curvos, movimento suave, cilíndricos; células isodiamétricas ou pouco mais longas ou mais curtas que largas; conteúdo celular homogêneo ou finamente granuloso; 
com aerótopos; célula apical arredondada ou levemente capitada; reprodução pela fragmentação dos tricomas.

O gênero compreende dois grupos ecológicos, um formado pelas espécies de água doce e outro formado pelas espécies marinhas. Segundo Komárek \& Hauer (2009), apenas duas espécies são de água doce. As espécies marinhas estão distribuídas em mares quentes e oceanos em todo o mundo, às vezes formando florações.

No presente estudo foi registrada a ocorrência de Trichodesmium lacustre.

Trichodesmium lacustre Klebahn, Flora, p. 82. 1895.

(Fig. 21G-I)

Tricomas arranjados paralelamente, formando feixes, retos ou flexuosos, 35,0-61,0 $\mu \mathrm{m}$ diâm.; tricomas retos, atenuados em direção ao ápice ou não atenuados, constritos, 4,5-7,0 $\mu \mathrm{m}$ diâm.; células 0,7-1,3 vez mais longas que largas, 4,5-7,0 $\mu \mathrm{m}$ compr.; conteúdo celular verdeacastanhado, levemente granuloso, com numerosos aerótopos; célula apical, às vezes, alongada e levemente atenuada, cilíndrica, com até 9,5 $\mu \mathrm{m}$ compr., sem espessamento.

Trichodesmium lacustre foi descrita a partir de material proveniente de ambiente lêntico de água doce (GEITLER, 1932). A espécie é tipicamente planctônica e já foi observada em regiões temperadas e tropicais (HINDÁK \& ZAGORENKO, 1992; SANT'ANNA \& AZEVEDO, 1995; FONSECA \& RODRIGUES, 2005).

As populações observadas apresentaram feixes com tricomas de diferentes morfotipos. Alguns tricomas não apresentaram aerótopos nas células, outros, na porção apical e atenuada do tricoma, a diminuição do diâmetro celular não era acompanhada de aumento no comprimento. No entanto, esse tipo de variação morfológica é observada na espécie (KOMÁREK \& ANAGNOSTIDIS, 2005).

A espécie foi observada apenas no plâncton.

Material examinado: HAS 104209, HAS 104227.

\section{OSCILLATORIACEAE (S. F. Gray) Harvey $e x$ Kirchner, 1898.}

A família Oscillatoriaceae, segundo Geitler (1932) e Desikachary (1959), é caracterizada por apresentar tricomas unisseriados, atenuados ou não, retos ou espiralados, com ou sem bainha mucilaginosa, com ou sem ramificações falsas; bainha mucilaginosa, 
firme ou difluente, homogênea ou lamelada, com um ou mais tricomas; células isodiamétricas, mais longas ou mais curtas que largas; reprodução através da divisão celular e pela formação de hormogônios.

Segundo Geitler (1932), Oscillatoriaceae é composta por 23 gêneros que diferem entre si pela morfologia dos tricomas, presença ou ausência de bainha mucilaginosa e presença e ausência de ramificações falsas.

Anagnostidis \& Komárek (1988), baseados em espécimes típicos de Oscillatoria, $O$. princeps e $O$. limosa, definiram Oscillatoriaceae a partir das seguintes características: tricomas cilíndricos, retos ou levemente ondulados, constritos ou não constritos; produção de bainha mucilaginosa facultativa (quando sob determinadas condições) ou obrigatória; bainha mucilaginosa firme, homogênea ou levemente lamelada, com um ou mais tricomas; ramificações falsas ocorrem facultativamente ou obrigatoriamente; células bem mais curtas que largas (discoides), raramente até isodiamétricas; célula apical, normalmente, com espessamento ou caliptra; reprodução por desintegração do tricoma e liberação de hormogônios, com formação de necrídios; tricomas raramente solitários, formando principalmente "mats" compactos, estratificados e prostrados no substrato.

Para estes autores, Oscillatoriaceae é composta por 10 gêneros, divididos em quatro subfamílias (Hormoscilloideae [2], Plectonematoideae [1], Starrioideae [4] e Oscillatorioideae [3]), de acordo com a morfologia do filamento e a frequência de ramificações falsas.

Segundo Komárek \& Anagnostidis (2005), a família Oscillatoriaceae é composta por duas subfamílias, cuja divisão é baseada na morfologia do tricoma: Oscillatorioideae, com tricomas isopolares, e Homoeotrichoideae, com tricomas heteropolares. Neste sistema de classificação, a subfamília Oscillatorioideae abrange cinco gêneros (Oscillatoria, Polychlamydium, Lyngbya, Plectonema e Blennothrix) e a Homoeotrichoideae abrange um único gênero (Homoeothrix).

No presente estudo foram identificadas oito espécies pertencentes a dois gêneros de Oscillatoriaceae, Lyngbya (1) e Oscillatoria (7).

\section{CHAVE PARA IDENTIFICAÇÃO DOS GÊNEROS ENCONTRADOS}

1. Tricomas envoltos por bainha mucilaginosa .................................................... Lyngbya

1. Tricomas sem bainha mucilaginosa …........................................................ Oscillatoria 


\section{Lyngbya Agardh ex Gomont, 1892.}

Espécie-tipo: Lyngbya confervoides Agardh ex Gomont, Ann. Sci. Nat. Bot., Sér. 7, v. 16, p. 118. 1892.

O gênero Lyngbya caracteriza-se por desenvolver filamentos espessos, raramente solitários, usualmente formando massas estratificadas; bainha mucilaginosa firme, usualmente lamelada, incolor ou colorida; tricomas retos ou levemente ondulados, imóveis ou levemente móveis, constritos ou não constritos, atenuados ou não em direção ao ápice; células cilíndricas, mais curtas que largas, discoides; conteúdo celular finamente granuloso (KOMÁREK \& ANAGNOSTIDIS, 2005).

Lyngbya é constituído principalmente por espécies que crescem formando massas aderidas a diferentes substratos de ambientes aerofíticos ou aquáticos. Raramente ocorrem no metafíton e poucas espécies ocorrem no plâncton como filamentos solitários. O gênero apresenta ampla distribuição no globo (GOMONT, 1892).

No presente estudo, foi identificada apenas uma espécies pertencentes ao gênero.

Lyngbya martensiana Meneghini ex Gomont, Ann. Sci. nat. Sér. 7, v. 16, p. 145. 1892.

(Figs. 17G, 22A)

Filamentos solitários, retos ou flexuosos, 8,0-13,5 $\mu \mathrm{m}$ diâm.; bainha mucilaginosa espessa, firme, homogênea, incolor a amarelada; tricomas não atenuados, não constritos, 6,59,0 $\mu \mathrm{m}$ diâm.; células 0,2-0,5 vez mais longas que largas, 2,0-4,0 $\mu \mathrm{m}$ compr.; conteúdo celular verde-azulado; septos granulosos; célula apical arredondada, sem espessamento.

Os espécimes analisados estão de acordo com os descritos por Gomont (1982). O autor comenta que a espécie foi encontrada em fontes termais, enquanto os espécimes observados foram encontrados em ambientes não termais. No entanto, segundo Frémy (1930), Lyngbya martensiana também pode ser encontrada em ambientes lênticos e lóticos, água salgada e em solos úmidos. Segundo Geitler (1932), a espécie é cosmopolita e, segundo Komárek \& Anagnostidis (2005), é amplamente distribuída pela Europa.

No Brasil, a espécie também apresenta ampla distribuição, ocorrendo em vários tipos de hábitats e praticamente em todas as regiões: norte (UHERKOVICH, 1981); centro-oeste (SENNA, 1996); sudeste (HUSZAR \& ESTEVES, 1988; SANT'ANNA et al., 1978; 1983; AZEVEDO, 1991; BRANCO et al., 1997); sul (OLIVEIRA et al., 1994; WERNER, 2002).

No presente estudo a espécie foi observada tanto no plâncton quanto no metafíton. Material examinado: HAS 104112, HAS 104124, HAS 104134, HAS 104202, HAS 104232, HAS 104234. 


\section{Oscillatoria Vaucher ex Gomont, 1892.}

Oscillatoria caracteriza-se por formar tufos micro ou macroscópicos, raramente tricomas solitários; tricomas cilíndricos, retos ou levemente ondulados, às vezes curvos no ápice, constritos ou não, atenuados ou não, normalmente sem bainha mucilaginosa, que ocorre quando sob situações de estresse; células curtas, discoides, sempre mais de duas vezes mais curtas que largas; conteúdo celular homogêneo ou com grânulos conspícuos; sem aerótopos; reprodução por meio da desintegração do tricoma em hormogônios curtos, com formação de necrídios (KOMÁREK \& ANAGNOSTIDIS, 2005).

Trata-se de um gênero amplamente distribuído ao redor do mundo, embora algumas espécies apresentem distribuição geograficamente bem limitada (KOMÁREK \& HAUER, 2009).

Inicialmente o gênero Oscillatoria compreendia grande diversidade morfológica e, atualmente, as principais características que distinguem o gênero dos demais gêneros que um dia já pertenceram a Oscillatoria (Phormidium, Planktothrix, Geitlerinema, Jaaginema, por exemplo) são o tricoma com células discoides e a ausência de bainha mucilaginosa.

Lyngbya é um gênero morfologicamente semelhante a Oscillatoria, pois ambos apresentam tricomas cilíndricos e células discóides, no entanto, Lyngbya obrigatoriamente apresenta bainha mucilaginosa e Oscillatoria não.

No presente estudo foram identificadas sete espécies do gênero Oscillatoria.

\section{Chave de identificação das espécies encontradas}

1. Tricomas atenuados 2

1. Tricomas não atenuados .5

2. Tricomas até $9,0 \mu \mathrm{m}$ diâm. .3

2. Tricomas maiores $9,0 \mu \mathrm{m}$ diâm.

3. Tricoma constrito, célula apical sem espessamento O. annae

3. Tricoma não constrito, célula apical com espessamento $O$. cf. anguina

4. Tricomas 9,0-16,0 $\mu \mathrm{m}$ diâm. O. curviceps

4. Tricomas 19,0-26,5 $\mu \mathrm{m}$ diâm. O. princeps

5. Tricomas retos O. tenuis

5. Tricomas curvos no ápice .6

6. Células apicais sem espessamento O. ornata

6. Células apicais com espessamento O. sancta 
Oscillatoria cf. anguina Bory ex Gomont, Ann. Sci. nat. Sér. 7, v. 16, p. 214. 1892.

(Figs. 18A, 22B-C)

Tricomas solitários, retos, curvos e gradualmente atenuados no ápice, não constritos, 6,4-9,0 $\mu \mathrm{m}$ diâm.; células 0,2-0,4 vez mais longas que largas, 1,5-3,0 $\mu \mathrm{m}$ compr.; conteúdo celular verde-azulado, homogêneo ou granuloso; septos não granulosos ou granulosos; célula apical arredondada, com espessamento.

Os espécimes observados são morfologicamente semelhantes a $O$. anguina e a $O$. proboscidea Gomont ex Gomont. Essas espécies diferem entre si, principalmente, pelo diâmetro dos tricomas: $O$. anguina com 6,0-8,0 $\mu \mathrm{m}$ diâm. e O. proboscidea com 12,0-15,0 $\mu \mathrm{m}$ diâm. (GOMONT, 1892). Comparando ainda, as demais características exibidas pelas duas espécies, nota-se que não existem outros fortes elementos que as diferenciem, pois as variações que elas apresentam acabam se sobrepondo, sendo o diâmetro do tricoma, o principal caráter distintivo.

De acordo com Komárek \& Anagnostidis (2005), tanto $O$. anguina como $O$. proboscidea apresentam ampla distribuição, sendo possivelmente cosmopolitas. Em relação ao hábitat, as duas espécies são encontradas em ambientes de água doce ou em solos úmidos.

A população observada apresenta características morfológicas semelhantes às descritas tanto para $O$. anguina como para $O$. proboscidea. Assim, os espécimes analisados foram identificados como $O$. cf. anguina por apresentarem tricomas levemente maiores que as referidas para a espécie por Gomont (1892).

Watanabe \& Komárek (1988), a partir do estudo do cianobactérias de Kathmandu Valley (Japão), também registraram a presença de populações semelhantes a $O$. anguina, denominadas $O$. cf. anguina. O material japonês também não foi confirmado por apresentar tricomas com diâmetros superiores aos citados para a espécie (7,5-8,5 $\mu \mathrm{m})$.

O registro da espécie no presente trabalho representa a primeira citação desta para o estado do Rio Grande do Sul.

Material examinado: HAS 104179, HAS 104180.

Oscillatoria annae Van Goor, Recl. Trav. Bot. néerl. v. 15, p. 289. 1918.

(Fig. 18B)

Tricomas solitários, retos, curvos e levemente atenuados no ápice, constritos, 7,4-8,2 $\mu \mathrm{m}$ diâm.; células 0,2-0,4 vez mais longas que largas, 1,9-2,5 $\mu \mathrm{m}$ compr.; conteúdo celular verde-azulado, granuloso; septos não granulosos; célula apical arredondada ou ligeiramente cônico-arredondada, sem espessamento. 
Os espécimes observados estão de acordo com a descrição original da espécie (VAN GOOR, 1918).

Segundo Geitler (1932), O. annae apresenta tricomas levemente atenuados e curvos no ápice, característica também observada em grande parte da população estudada. Algumas populações brasileiras não apresentam essas particularidades (SANT'ANNA, 1984; SENNA, 1988), mas possuem dimensões celulares que estão de acordo com a espécie.

Embora $O$. annae tenha sido descrita a partir de material proveniente do plâncton de ambientes lênticos, a espécie já foi documentada formando talos macroscópicos junto à margem de lagos (DESIKACHARY, 1959; COMPÈRE, 1967). No Brasil, Sant'Anna \& Azevedo (1995) e Werner (2002) registraram a presença de populações de $O$. annae formando massas verde-azuladas sobre o solo úmido.

A população estudada foi registrada apenas no plâncton.

Material examinado: HAS 104427.

Oscillatoria curviceps Agardh ex Gomont, Ann. Sci. nat. Sér. 7, v. 16, p. 213. 1892.

(Figs. 18D, 22D)

Tricomas solitários, retos, curvos e levemente atenuados no ápice, não constritos, 9,016,0 $\mu \mathrm{m}$ diâm.; células 0,1-0,4 vez mais longas que largas, 1,7-3,5 $\mu \mathrm{m}$ compr.; conteúdo celular verde-azulado, homogêneo; septos com ou sem grânulos; célula apical arredondadotruncada, com espessamento.

Embora a população estudada tenha apresentado indivíduos com diâmetros levemente inferiores aos citados na literatura, os espécimes analisados foram identificados como $O$. curviceps por possuírem características morfológicas e métricas que estão de acordo com as citadas para a espécie por Gomont (1892).

Embora O. curviceps seja observada formando talos macroscópicos (SILVA, 1991; SANT'ANNA \& AZEVEDO, 1995; KOMÁREK \& ANAGNOSTIDIS, 2005, McGREGOR, 2007), no presente estudo foram observados apenas tricomas solitários, ocorrendo na zona litorânea da lagoa dos Gateados.

O presente trabalho constitui a primeira citação da ocorrência de $O$. curviceps no Rio Grande do Sul.

Material examinado: HAS 104134, HAS 104174. 
Oscillatoria ornata Kützing ex Gomont, Ann. Sci. nat. Sér. 7, v. 16, p. 214. 1892.

(Figs. 18C, 22E)

Tricomas solitários, retos ou flexuosos, retos ou curvos no ápice, não atenuados, constritos, 8,0-10,0 $\mu \mathrm{m}$ diâm.; células 0,2-0,4 vez mais longas que largas, 1,8-3,5 $\mu \mathrm{m}$ compr.; conteúdo celular verde-azulado, homogêneo; septos com ou sem grânulos; célula apical arredondada, sem espessamento.

A população estudada difere no escrito por Gomont (1892) apenas por apresentar alguns espécimes com tricomas levemente mais estreitos; apesar disto, a população foi identificada como $O$. ornata por apresentar características morfométricas que correspondem às descritas para a espécie na literatura consultada (GOMONT, 1892; GEITLER, 1932; DESIKACHARY, 1959; KOMÁREK \& ANAGNOSTIDIS, 2005).

Embora a espécie seja caracterizada por apresentar tricomas espiralados no ápice, a população analisada apresentou tanto espécimes típicos como espécimes com tricomas retos. Esta característica já foi observada em outras populações brasileiras (BICUDO \& VENTRICE, 1968; WERNER, 1988; WERNER \& ROSA, 1992; SANT'ANNA \& AZEVEDO, 1995).

Este táxon foi documentado para o estado do Rio Grande do Sul por Callegaro et al. (1981), Werner (1984, 1988) e Rosa et al. (1987).

No presente estudo, os espécimes observados foram registrados apenas no plâncton da lagoa dos Gateados.

Material examinado: HAS 104178.

Oscillatoria princeps Vaucher ex Gomont, Ann. Sci. nat. Sér. 7, v. 16, p. 206. 1892.

(Figs. 18E, 22F)

Tricomas solitários, retos ou levemente curvos no ápice, não atenuados ou levemente atenuados, não constritos a levemente constritos, 19,0-26,5 $\mu \mathrm{m}$ diâm.; células até 0,4 vez mais longas que largas, 2,5-4,0 $\mu \mathrm{m}$ compr.; conteúdo celular verde-azulado, homogêneo ou levemente granuloso; septos não granulosos; célula apical arredondada ou arredondadotruncada, com ou sem espessamento.

Os espécimes observados concordam com os descritos por Gomont (1892). Apesar de a espécie exibir uma ampla variação no que diz respeito ao diâmetro dos tricomas (GOMONT, 1892, GEITLER, 1932; KOMÁREK \& ANAGNOSTIDIS, 2005), inclusive em populações brasileiras (SANT'ANNA \& AZEVEDO, 1995; WERNER \& ROSA, 1992; SENNA, 1996; AZEVEDO et al., 1996; WERNER, 2002), isso não foi observado nas 
populações analisadas, uma vez que os diâmetros se concentraram próximos ao limite inferior citado para a espécie.

Oscillatoria princeps é uma espécie amplamente distribuída, sendo considerada cosmopolita (KOMÁREK \& ANAGNOSTIDIS, 2005; McGREGOR, 2007). É principalmente bentônica, mas pode ser encontra em pequenos aglomerados livres na coluna d'água (GOMONT, 1892). A espécie também já foi registrada ocorrendo em ambientes de água salobra ou salgada e subaéreos (SANT'ANNA et al. 1985).

Nas populações analisadas, foram encontradas somente tricomas solitários, tanto no plâncton como no metafíton.

Material examinado: HAS 104117, HAS 104125, HAS 104131, HAS 104167, HAS 104178, HAS 104203, HAS 104235, HAS 104449, HAS 104445, HAS 104450, HAS 104451, HAS 104455.

Oscillatoria sancta Kützing ex Gomont, Ann. Sci. nat. Sér. 7, v. 16, p. 209. 1892.

(Fig. 18F)

Tricomas solitários, retos ou flexuosos, retos ou levemente curvos no ápice, constritos, 8,0-10,5 $\mu \mathrm{m}$ diâm.; células 0,2-0,5 vez mais longas que largas, 2,0-4,5 $\mu \mathrm{m}$ compr.; conteúdo celular verde-azulado; septos granulosos; célula apical arredondada ou arredondado-truncada, às vezes capitada, com espessamento.

Os espécimes observados estão de acordo com os descritos na literatura (KOMÁREK \& ANAGNOSTIDIS, 2005).

Oscillatoria gracile Azevedo et Sant'Anna é uma espécie muito semelhante a $O$. sancta. Ambas apresentam tricomas com diâmetros que se sobrepõem, além de células apicais capitadas e com espessamento. No entanto, $O$. gracile difere de $O$. sancta por apresentar tricomas não constritos, sempre retos e não atenuados.

Oscillatoria sancta é considerada uma espécie cosmopolita, ocorrendo em uma ampla variedade de hábitats (KOMÁREK \& ANAGNOSTIDIS, 2005; McGREGOR, 2007). Segundo Gomont (1892), O. sancta ocorre sobre solos ou rochas úmidas ou ainda em tanques. No entanto, os espécimes observados foram encontrados no plâncton da lagoa do Casamento. Segundo Geitler (1932) a espécie também pode ser encontrada em ambientes lênticos ou lóticos.

Outras populações brasileiras também foram observadas ocorrendo no plâncton de ambientes de água doce (CAMPOS \& SENNA, 1989; SANT'ANNA \& AZEVEDO, 1995; PERES E SENNA, 1998). 
Material examinado: HAS 104117.

Oscillatoria tenuis Agardh ex Gomont, Ann. Sci. nat. Sér. 7, v. 16, p. 220. 1892.

(Figs. 18G, 22G)

Tricomas solitários, retos, não atenuados, não constritos a levemente constritos, 6,511,0 $\mu \mathrm{m}$ diâm.; células 0,2-0,4 vez mais longas que largas, 2,0-3,8 $\mu \mathrm{m}$ compr.; conteúdo celular verde-azulado, homogêneo; septos com ou sem grânulos; célula cilíndricoarredondada, sem espessamento.

As populações observadas possuem características morfológicas e métricas que estão de acordo com as referidas para a espécie por Komárek \& Anagnostidis (2005).

Oscillatoria tenuis pode ser confundida com Phormidium tergestinum. Ambas apresentam tricomas retos, não atenuados; septos granulados ou não. No entanto, O. tenuis possui células mais curtas, característica do gênero Oscillatoria.

Oscillatoria tenuis constitui uma espécie de ampla distribuição, ocorrendo geralmente como tricomas solitários entre outras cianobactérias filamentosas, algas e macrófitas aquáticas.

No presente estudo, os espécimes foram observados tanto no plâncton quanto no metafíton.

Material examinado: HAS 104117, HAS 104124, HAS 104125, HAS 104134, HAS 104174, HAS 104203, HAS 104207, HAS 104213, HAS 104360, HAS 104431, HAS 104435, HAS 104442, HAS 104451, HAS 104455. 


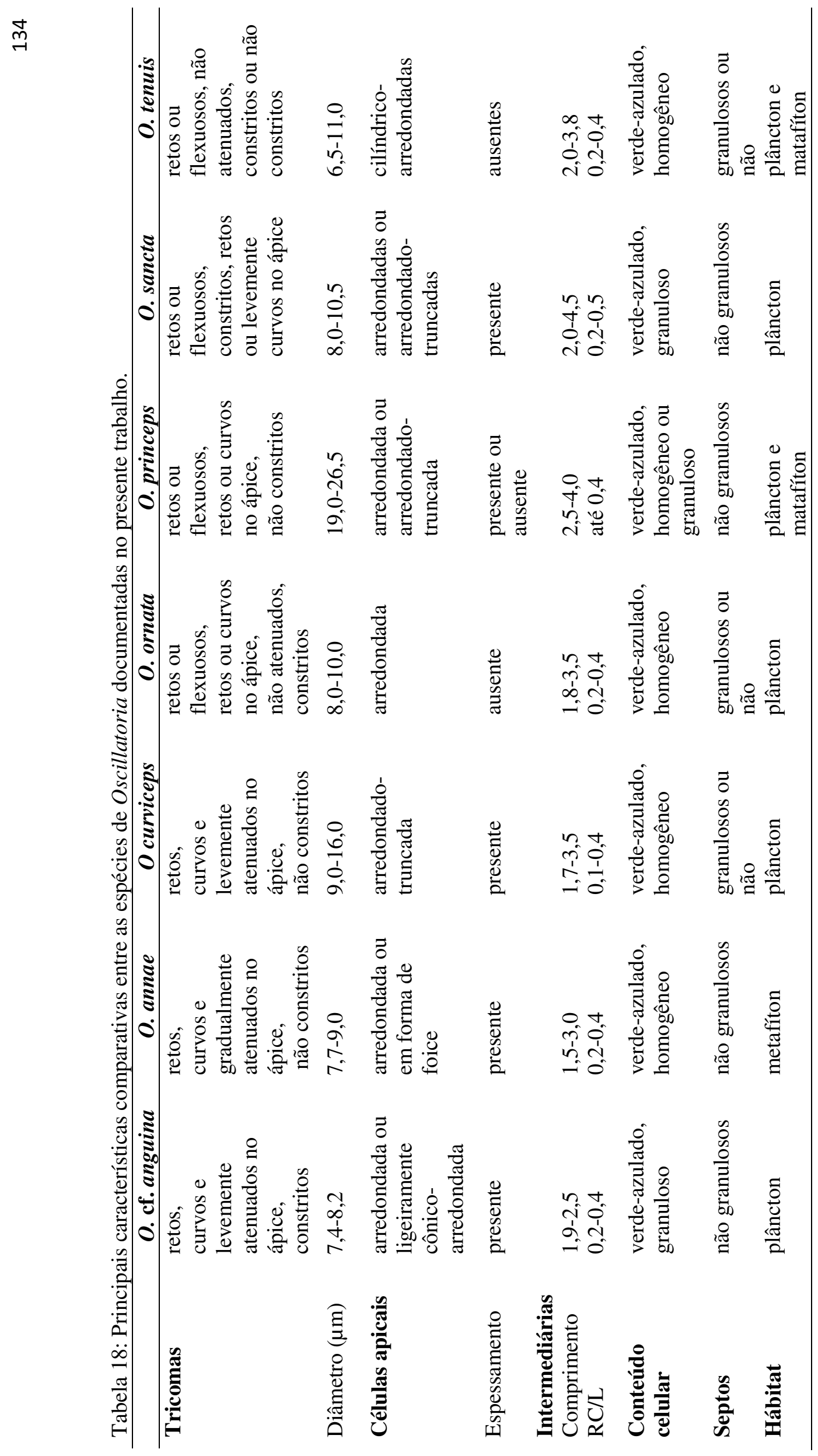




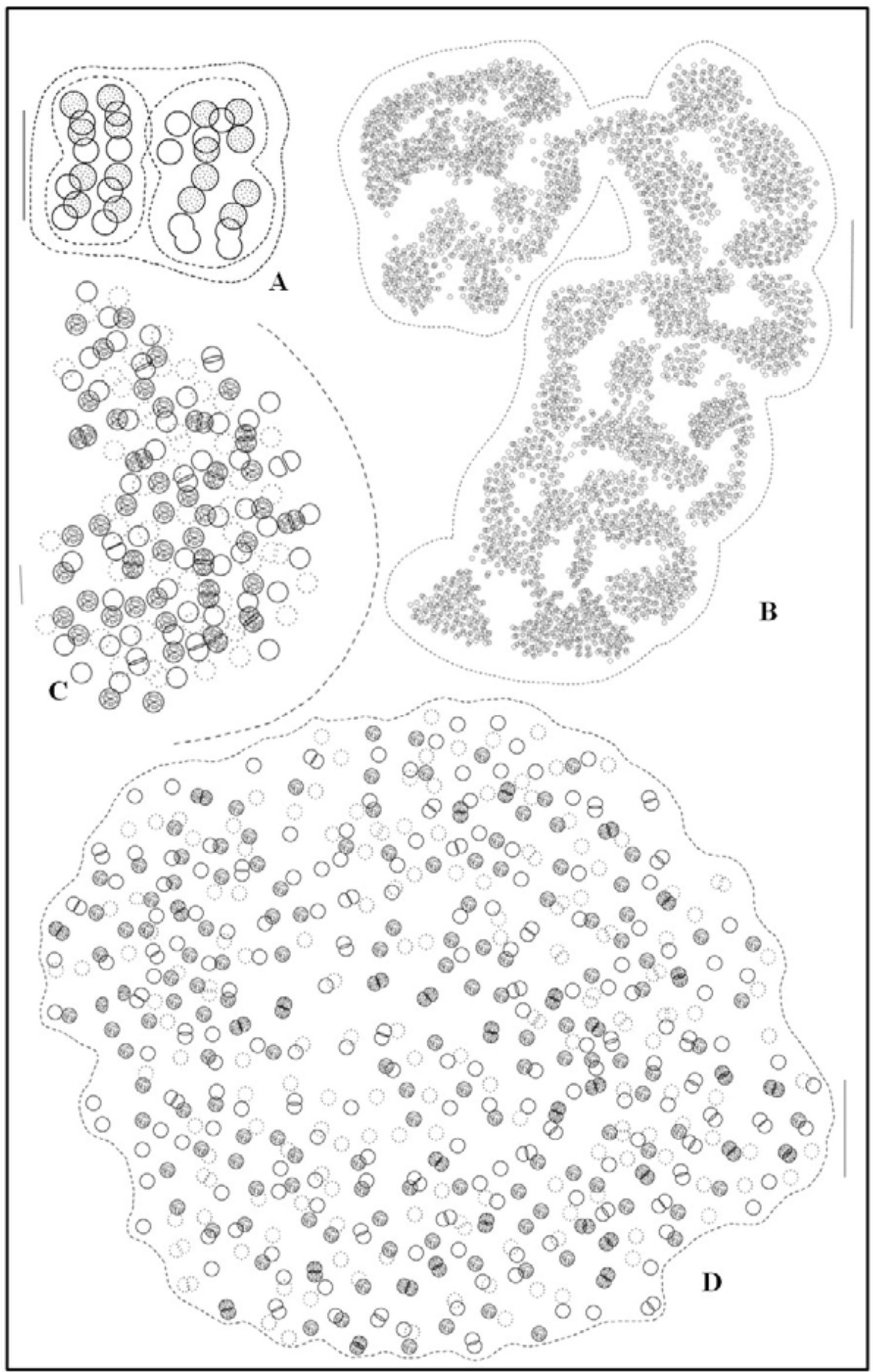

Fig. 13: A-D. A. Eucapsis parallelepipedon (Schmidle) Komárek et Hindák; B-C. Microcystis aeruginosa Kützing; D. M. protocystis Crow. Escalas: A, C $=10 \mu \mathrm{m} ; \mathrm{D}=50 \mu \mathrm{m} ; \mathrm{B}=100 \mu \mathrm{m}$. 


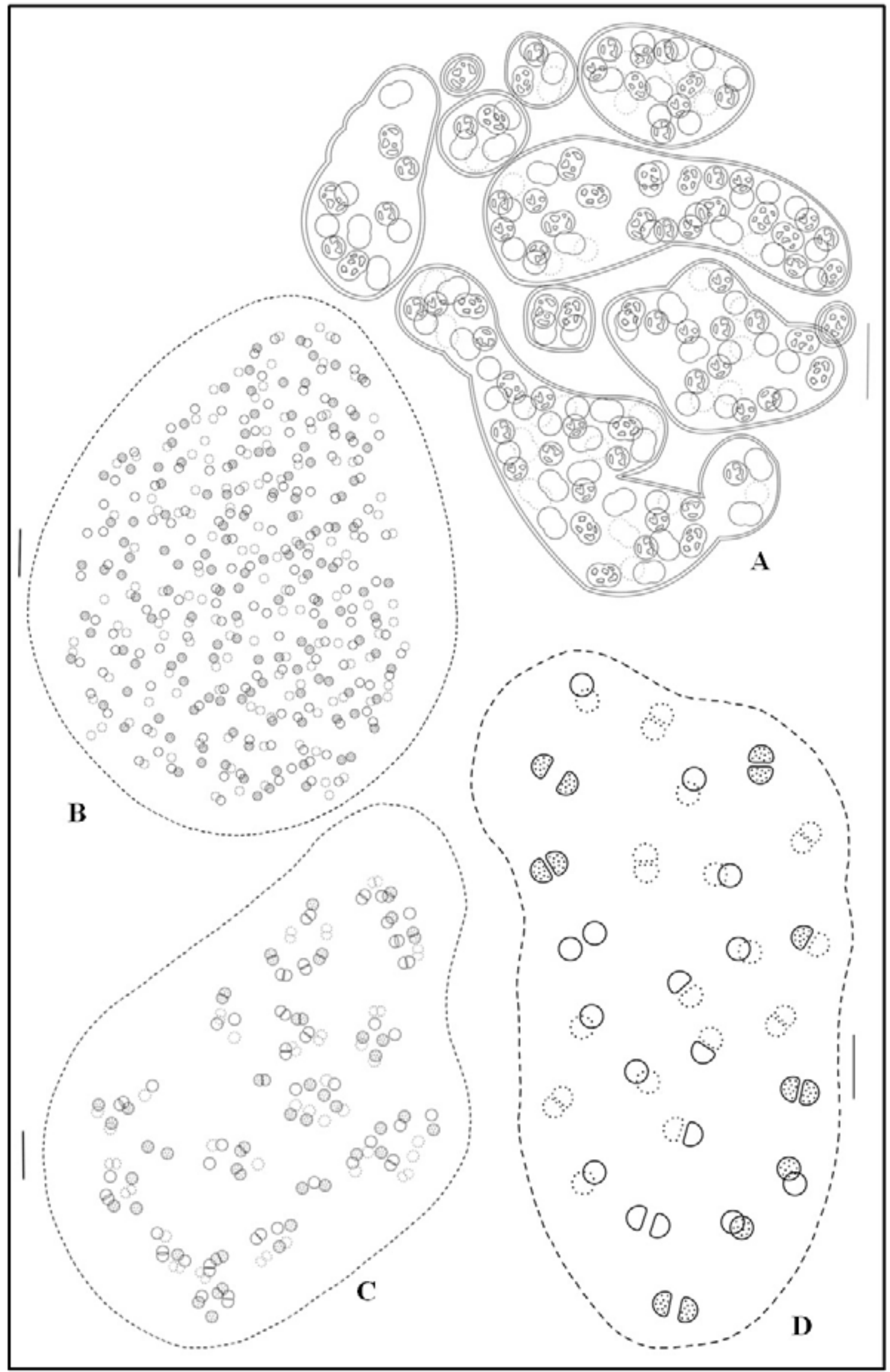

Fig. 14: A-D. A. Microcystis wesenbergii (Komárek) Komárek; B. $M$ smithii Komárek et Anagnostidis; C. Chroococcus dispersus (Keissler) Lemmermann; D. C. distans (G. M. Smith) Komárková-Legnerová et Cronberg. Escalas: $\mathrm{A}-\mathrm{B}=20 \mu \mathrm{m}$; $\mathrm{C}-\mathrm{D}=10 \mu \mathrm{m}$. 


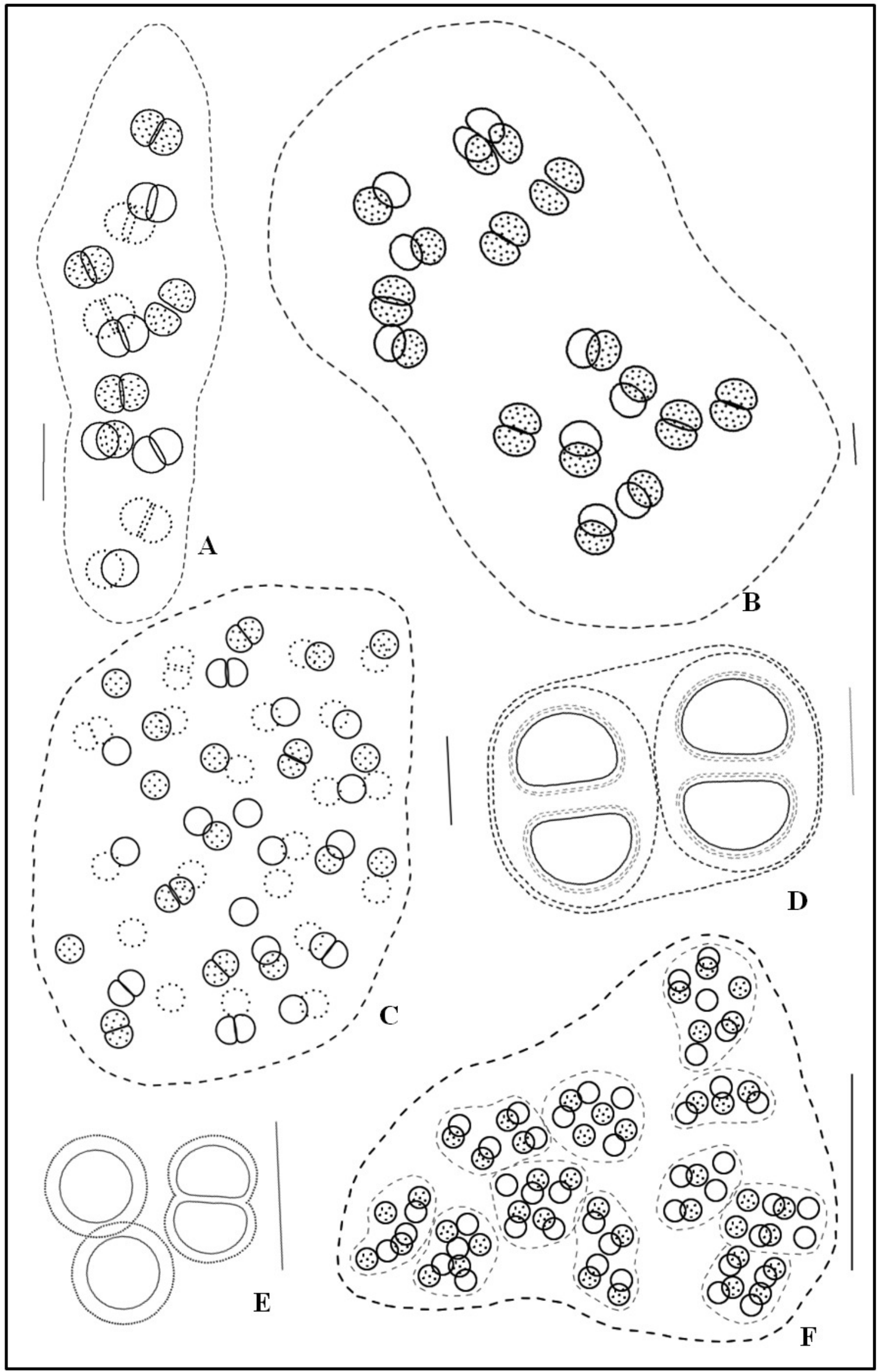

Fig. 15: A-F. A-B. Chroococcus limneticus Lemmermann; C. C. minimus (Keissler) Lemmermann; D. C. turgidus (Kützing) Nägeli; $\quad$ E. C. mimutus (Kützing) Nägeli; F. C. microscopicus KomárkováLegnerová et Cronberg. Escalas: $10 \mu \mathrm{m}$. 


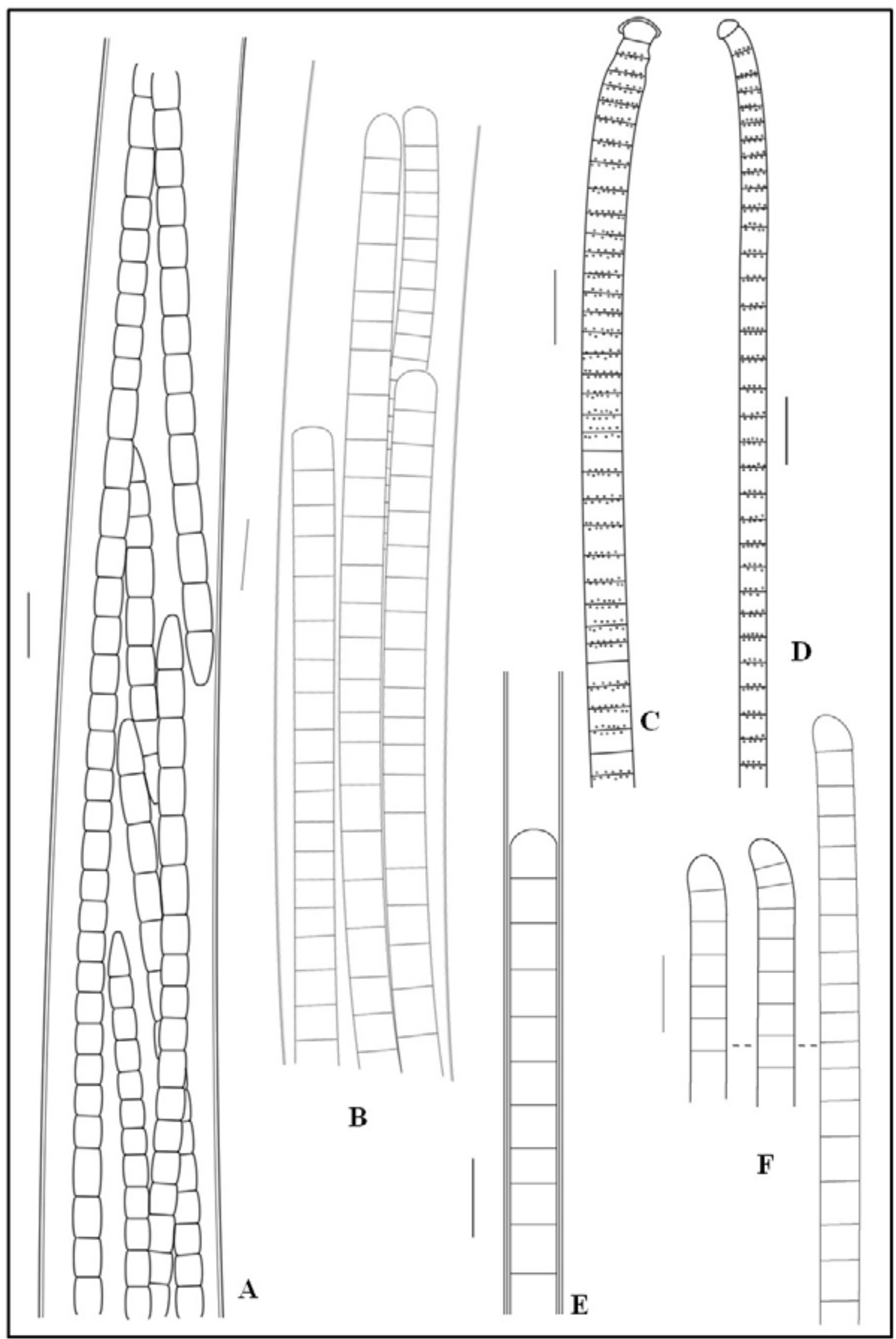

Fig. 16: A-F. A. Microcoleus lacustris (Rabemhorst) Farlow ex Gomont; B. M. subtorulosus Gomont ex Gomont; C. Phormidium autummale (Agardh) Trevisan ex Gomont; D. $P$. amoenum Kützing ex Anagnostidis et Komárek; E. P. aerugmeo-caeruleum (Gomont) Anagnostidis et Komárek; F. P. chalybeum (Mertens ex Gomont) Anagnostidis et Komárek. Escalas: $10 \mu \mathrm{m}$. 


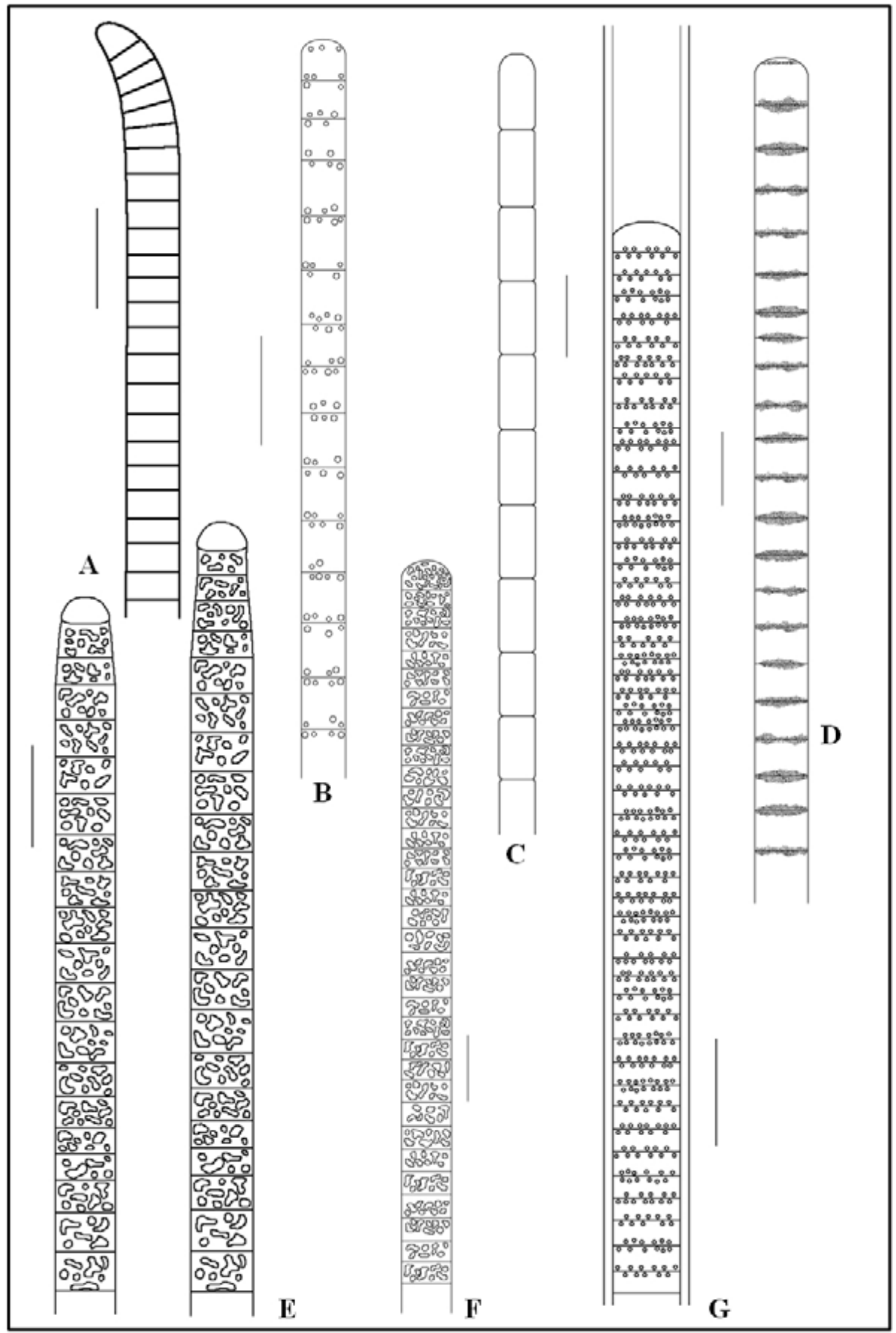

Fig. 17: A-G. A. Phonnidium fonmosum (Bory ex Gomont) Anagnostidis et Komárek; B. $P$. granulatum (Gardner) Anagnostidis; C. P. hamelii (Frémy) Anagnostidis et Komárek; D. P. tergestinum (Kützing) Anagnostidis et Komárek; E. Planktothrix agardhü (Gomont) Anagnostidis et Komárek; F. P. isothrix (Skuja) Komárek et Komárková; G. Lyngbya martensiana (Meneghini ex Gomont) Komárek et Anagnostidis. Escalas: $10 \mu \mathrm{m}$. 


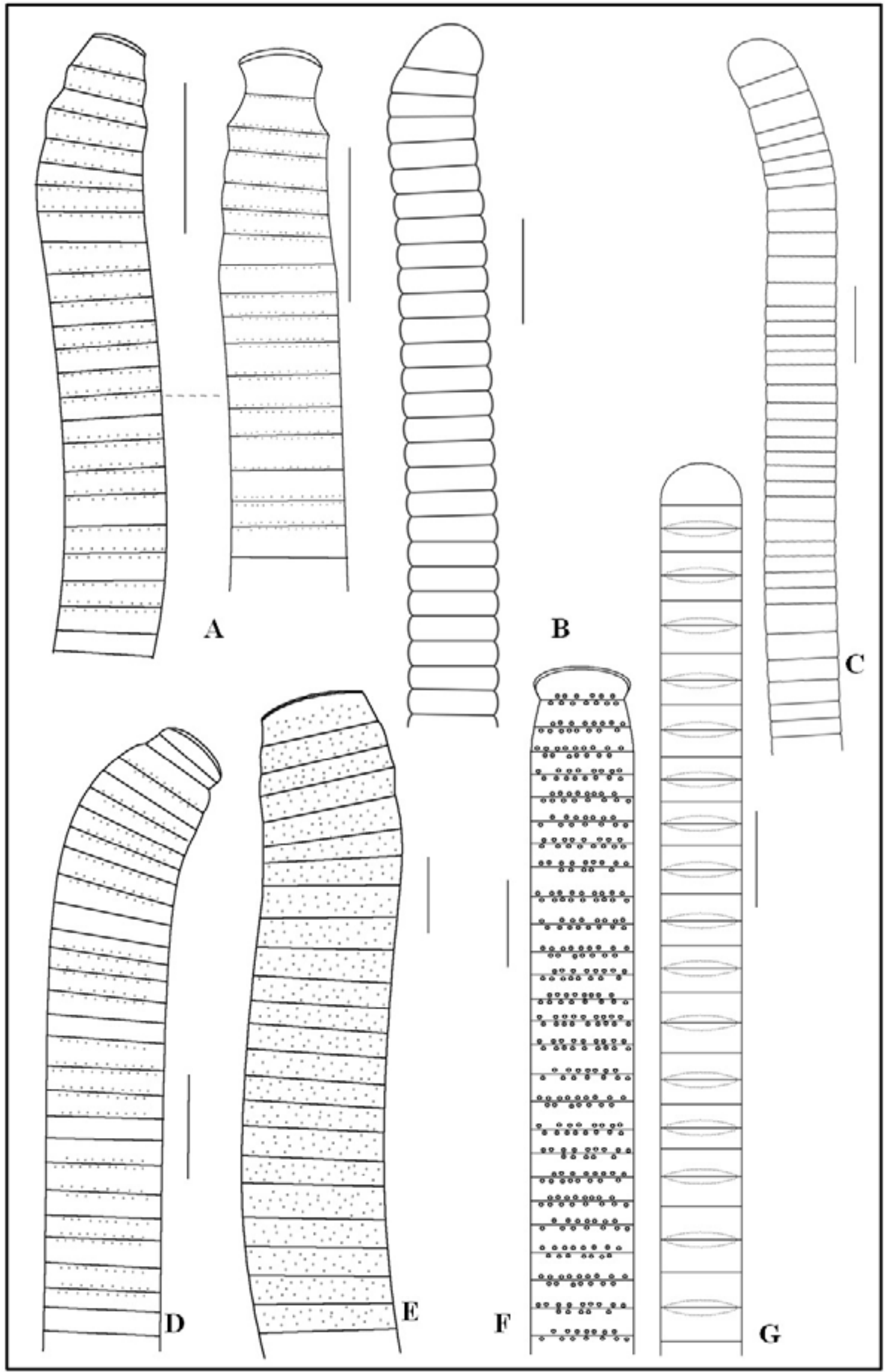

Fig. 18: A-G. A. Oscillatoria cf. anguina Bory ex Gomont; B. $O$. annae Van Goor; C. $O$. ornata Kützing ex Gomont; D. O. curviceps Agardh ex Gomont; E. O primceps Vaucher ex Gomont; F. O. sancta Kützing ex Gomont; G. O. temuis Agardh ex Gomont. Escala: $10 \mu \mathrm{m}$. 


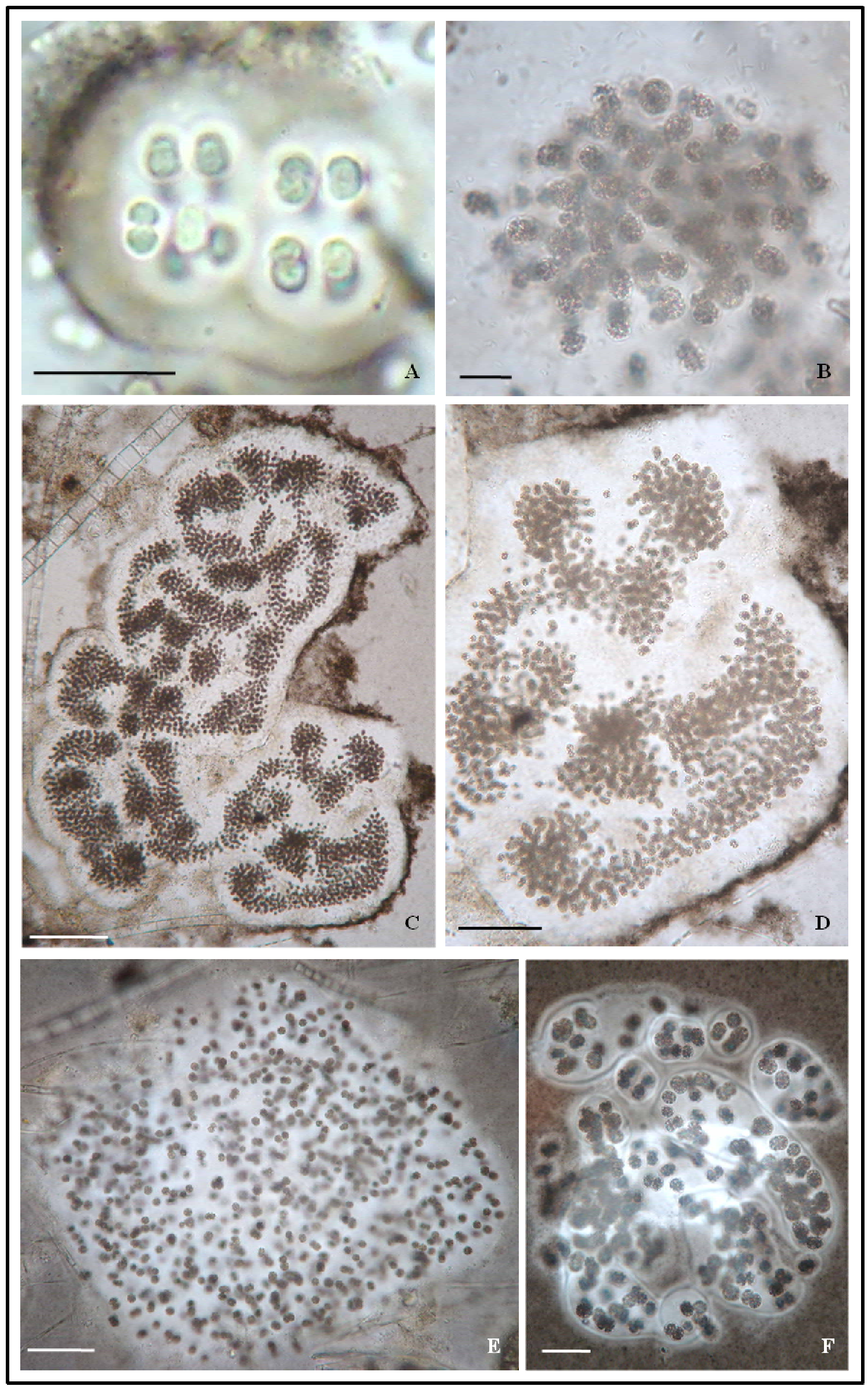

Fig. 19: A-F. A. Elcopsis parallelepipedon (Sclmidle) Komatel et Hindal:: B-D. Microcistis aenginosa Kützing: E. M. protoctstis (how: F. M. wesenbergi (Komateli) Komáde. Escalas: A-B = $10 \mu \mathrm{m} ; \mathrm{D}-\mathrm{F}=20 \mu \mathrm{m} ; \mathrm{C}=100 \mu \mathrm{m}$ 


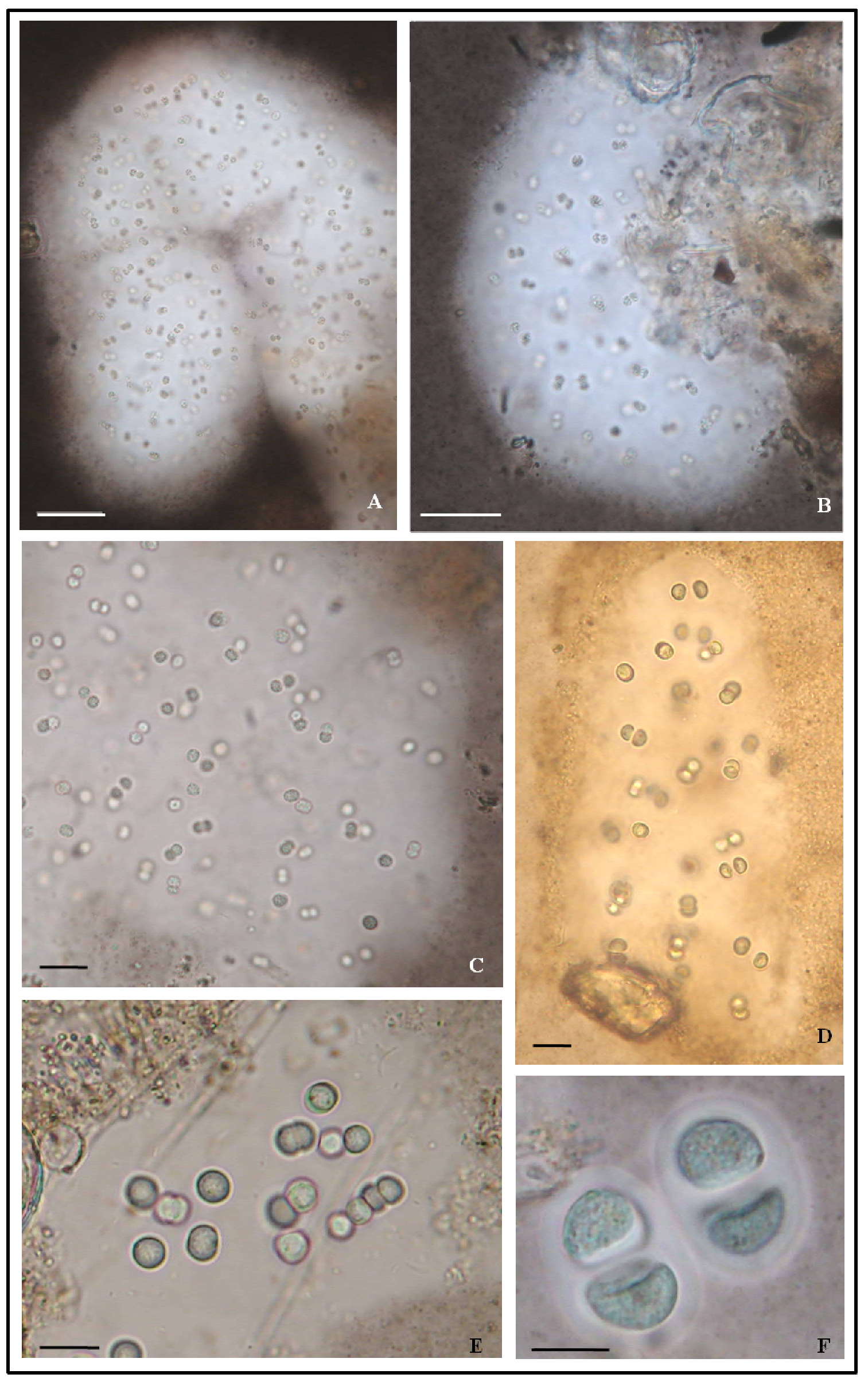

Fig. 20: A-F. A-C. Microctstis surthii Komatel et Anagnostidis: D. Chroococus distans (G. M. Smith) Komàrlovà-Legnerova et Cronberg: E. C. limmeticus Lemmemann: F. (c. turgidus (Kützing) Nägeli. Escalas: $\mathrm{A}-\mathrm{B}, \mathrm{E}=20 \mu \mathrm{m}$, C-D, $\mathrm{F}=10 \mu \mathrm{m}$. 


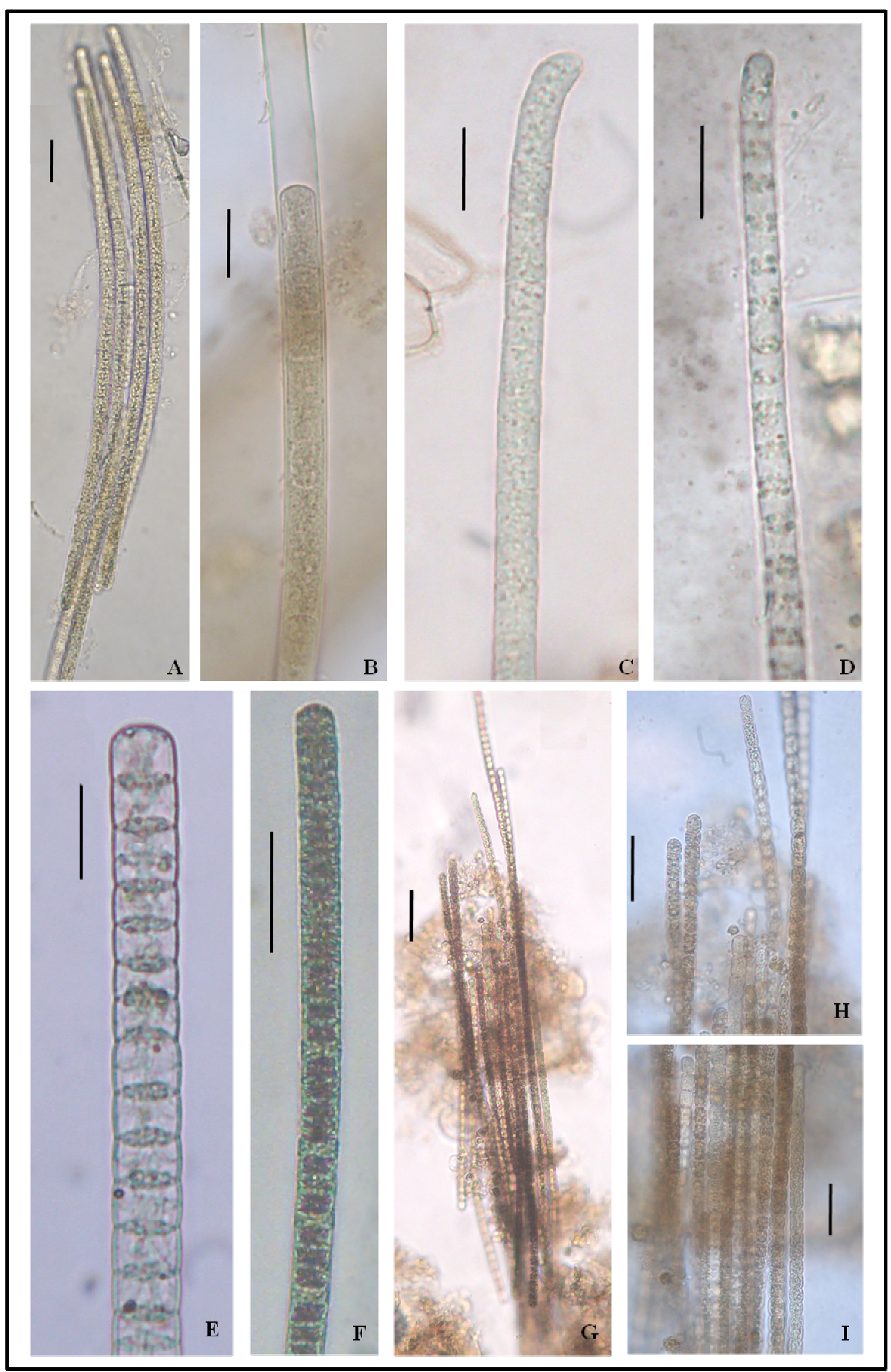

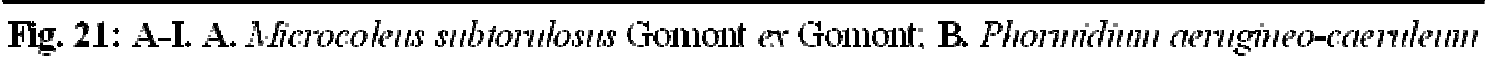

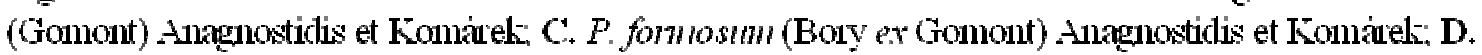
F.grmilam (Gaddner) Anagnostidis: E. F. tergestmm (Kützing) Anagnostidis et Komarel:: F.

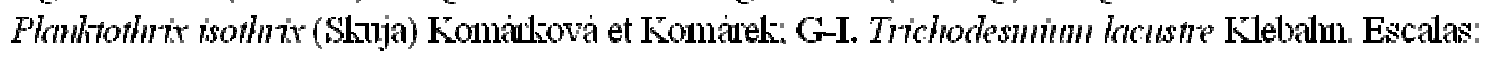
A. H. I $=20 \mu \mathrm{m} ; \mathrm{B}-\mathrm{F}=10 \mu \mathrm{m} ; \mathrm{G}=50 \mu \mathrm{m}$. 


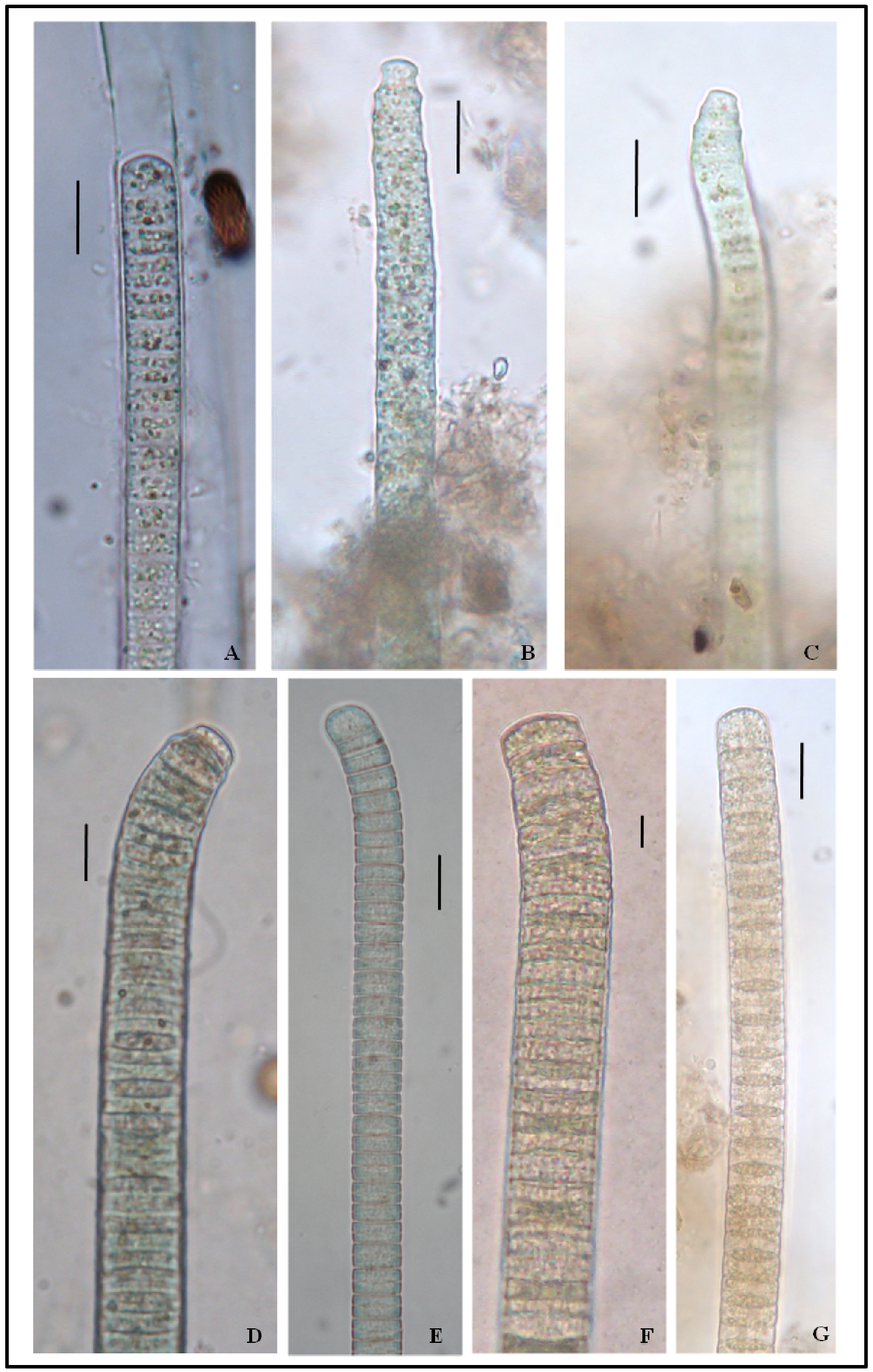

Fig. 22: A-G. A. Lingbta mantensiana (Meneghini ex Gomont) Anagnostidis et Komatel: BC. Oscillatoria cf. anguma Bory ex Gomont: D. O. anriceps Agardh ex Gomont: E. O. omata Kützing ex Gomont: F. O princeps Vaucher ex Gomont: G. O. temis Agardh ex Gomont. Escalas: $10 \mu \mathrm{m}$. 


\subsection{NOSTOCOPHYCIDAE}

A subclasse Nostocophycidae compreende as cianobactérias filamentosas heterocitadas e apresentam tilacoides dispostos irregularmente nas células. É composta apenas pela ordem Nostocales.

\section{NOSTOCALES}

A ordem compreende as cianobactérias filamentosas heterocitadas incluindo tanto os táxons não ramificados como os que apresentam ramificações falsas ou verdadeiras.

Bornet \& Flahault (1886-1888) classificaram as cianobactérias filamentosas heterocitadas na família Hormogoneae, subfamília Heterocysteae. Segundo esses autores, os 30 gêneros da família eram divididos em quatro tribos, baseado em caracteres morfológicos tais como o tipo e a disposição de heterócitos e acinetos e, ainda, presença ou ausência de ramificações falsas ou verdadeiras: Nostocaceae (Anabaena, Aphanizomenon, Aulosira, Cylindrospermum, Hormothamnion, Nodularia, Nostoc e Wollea), Rivulariaceae (Amphithrix, Brachytrichia, Calothrix, Dicothrix, Gloeotrichia, Isactis, Leptochaete, Polythrix, Rivularia e Sacconema), Sirosiphoniaceae (Capsosira, Hapalosiphon, Mastigocoleus, Nostochopsis e Stigonema) e Scytonemataceae (Desmonema, Diplocolon, Hassallia, Hydrocoryne, Microchaete, Scytonema e Tolypothrix).

Geitler (1925) organizou as cianobactérias que compunham a família Hormogoneae em duas ordens, Stigonematales e Nostocales, segundo o tipo de tricoma e de ramificações. Segundo o autor, Stigonematales abrange 20 gêneros distribuídos em seis famílias (Capsisoraceae, Loefgreniaceae, Loriellaceae, Nostochopsaceae, Pulvinulariaceae e Stigonemataceae) e Nostocales abrange 52 gêneros distribuídos em seis famílias (Mastigocladaceae, Microchaetaceae, Nostocaceae, Oscillatoriaceae, Rivulariaceae e Scytonemataceae). Posteriormente, Geitler (1932) classificou as Hormogoneae em apenas uma ordem, Hormogonales, incluindo as famílias Leptobasaceae e Sokoloviaceae.

De acordo com Bourrelly (1970), Nostocales é dividida em cinco famílias (Microchaetaceae, Nostocaceae, Oscillatoriaceae, Rivulariaceae e Scytonemataceae) e 
Stigonematales em seis famílias (Borzinemataceae, Capsosiraceae, Mastigocladaceae, Mastigocladopsidaceae, Nostochopsidaceae e Stigonemataceae).

Posteriormente, Komárek \& Anagnostidis (1989) e Anagnostidis \& Komárek (1990), classificaram as cianobactérias heterocitadas em duas ordens baseados na presença (Stigonematales) ou ausência (Nostocales) de ramificações verdadeiras..

De acordo com Komárek \& Anagnostidis (1989), Nostocales caracteriza-se por apresentar filamentos unisseriados; tricomas iso ou heteropolares, sem ramificações ou com ramificações falsas; habilidade de produzir heterócitos, ausente apenas nos gêneros Raphidiopsis e Isocystis ou em determinadas fases do ciclo de vida; produção de acinetos facultativa, ausente em Richelia; divisão celular em um plano exclusivamente perpendicular ao eixo do tricoma; reprodução por hormogônios ou hormocitos. Compreende 33 gêneros distribuídos em quatro famílias: Scytonemataceae (3), Microchaetaceae (8), Rivulariaceae (7) e Nostocaceae (15).

Stigonematales, segundo Anagnostidis \& Komárek (1990), é composta por cianobactérias que exibem as seguintes características: tricomas uni, bi ou multisseriados, com ramificações verdadeiras; habilidade de produzir heterócitos; a produção de acinetos é rara; divisão celular em mais de um plano, perpendicular, longitudinal ou oblíquo ao eixo de tricoma; reprodução por meio de hormogônios ou hormocistos. De acordo com essa classificação, a ordem é composta por 48 gêneros distribuídos em oito famílias: Chlorogloeocapsaceae (2), Capsosiraceae (6), Stigonemataceae (3), Fischerellaceae (6), Borzinemataceae (5), Loriellaceae (8), Nostochopsaceae (4) e Mastigocladaceae (14).

No entanto, dados moleculares (GUGGER \& HOFFMANN, 2004) não suportam a separação das cianobactérias heterocitadas nas ordens Nostocales e Stigonematales e mostram que, isoladamente, ambas são polifiléticas. Assim, o caráter tipo de ramificação (falsa ou verdadeira), previamente considerado diagnóstico para diferenciar as duas ordens, pode ser usado somente para definir gêneros e famílias.

Por outro lado, as evidências moleculares também apontam uma origem comum a todas as cianobactérias heterocitadas, revelando o caráter monofilético desses organismos (GUGGER \& HOFFMANN, 2004).

Assim Hoffmann et al. (2005) incorporaram essas informações e definiram que a ordem Nostocales abrange todas as cianobactérias heterocitadas, estando distribuídas em 10 famílias (Scytonemataceae, Symphyonemataceae, Borzinemataceae, Rivulariaceae, Microchaetaceae, Nostocaceae, Chlorogloeopsidaceae, Hapalosiphonaceae, Loriellaceae e Stigonemataceae). 
No presente trabalho foram registrados 27 espécies específicos de Nostocales pertencentes a seis famílias.

\section{CHAVE PARA IDENTIFICAÇÃO DAS FAMÍLIAS ENCONTRADAS}

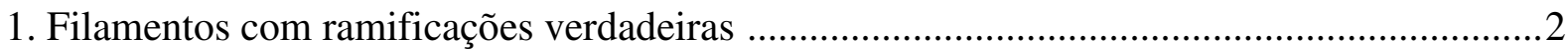

1. Filamentos sem ramificações verdadeiras ..................................................................... 3

2. Filamentos unisseriados, até $12,5 \mu \mathrm{m}$ diâm....................................... Mastigocladaceae

2. Filamentos uni ou multisseriados, maiores 18,5 m diâm. ........................ Stigonemataceae

3. Filamentos não ramificação ............................................................................ Nostocaceae

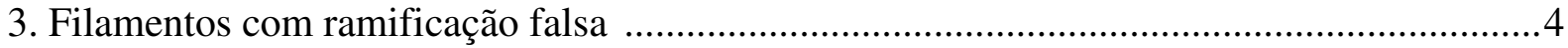

4. Filamentos isopolares …................................................................ Scytonemataceae

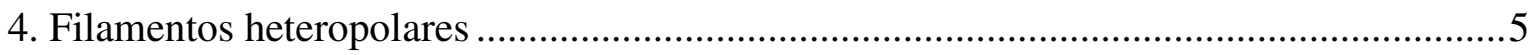

5. Filamentos atenuados em uma das extremidades ........................................ Rivulariaceae

5. Filamentos não atenuados ................................................................... Microchaetaceae

\section{SCYTONEMATACEAE Frank, 1886.}

Essa família caracteriza-se por desenvolver filamentos unisseriados, tricomas isopolares com ramificações falsas e, geralmente, duplas, raramente simples, iniciadas a partir de células vegetativas; heterócitos intercalares; reprodução por hormogônios (KOMÁREK \& ANAGNOSTIDIS, 1989).

Scytonemataceae difere de Microchaetaceae por apresentar tricomas isopolares e a desintegração do tricoma é feita sem participação do heterócito. As duas famílias também diferem quanto à formação dos hormogônios, que é isopolar em Scytonemataceae.

A família compreende três gêneros, Scytonema, Scytonematopsis e Kyrtuthrix, dentre os quais apenas Scytonema está representada neste estudo. 


\section{Scytonema Agardh ex Bornet et Flahault, 1888.}

Espécie-tipo: Scytonema hofmannii Agardh ex Bornet et Flahault, Ann. Sci. Nat. Bot., Sér. 7, v. 5 , p. 85.1888 .

Filamentos solitários ou formando massas; ramificações falsas presentes, simples ou duplas; tricomas isopolares, cilíndricos, constritos ou não; bainha mucilaginosa firme, margem evidente, homogênea ou lamelada, hialina ou pigmentada, em geral amarelada; células cilíndricas; heterócitos intercalares, solitários, raramente aos pares, cilíndricos ou em forma de barril; acinetos raramente observados; zona meristemática pode estar presente; reprodução por hormogônios.

São organismos encontrados em vários tipos de ambientes, principalmente em regiões tropicais. Grande parte das espécies que compõem o gênero é aerofítica, crescendo sobre rochas úmidas, entre briófitas ou outros substratos. Algumas crescem submersas, sendo encontradas principalmente em lagoas costeiras, e poucas espécies são marinhas (KOMÁREK \& HAUER, 2009).

No presente estudo, foi identificada apenas uma espécie do gênero, S. mirabile.

Scytonema mirabile (Dillwyn) Bornet, Bull. Soc. Bot. Fr., v. 36, p. 155. 1889.

Basônimo: Conferva mirabilis Dillwyn, Brit. Conf., p. 96. 1808.

(Fig. 32A-E)

Filamentos solitários, 18,0-27,0 $\mu$ m diâm.; bainha mucilaginosa espessa, firme, incolor a amarelada, lamelas levemente divergentes; tricomas constritos e não constritos, 5,4-10,0 $\mu \mathrm{m}$ diâm.; células quadráticas a mais longas que largas, 5,0-15,0 $\mu \mathrm{m}$ compr.; conteúdo celular verde-azulado, granuloso; heterócitos intercalares, quadráticos a mais longos que largos, 8,010,5 $\mu \mathrm{m}$ diâm., 8,0-13,5 $\mu \mathrm{m}$ compr.

Os espécimes observados apresentam características morfológicas e métricas de acordo com as descritas para a espécie (FRÉMY, 1930; GEITLER, 1932), exceto quanto ao diâmetro do filamento, que apresentou valores maiores que os referidos na literatura $(15,0$ 21,0 $\mu \mathrm{m})$. No entanto, Asencio \& Aboal (1996), em populações encontradas na Espanha, também observaram filamentos com bainhas mucilaginosas mais espessas (16,0-28,0 $\mu \mathrm{m})$.

Segundo Geitler (1932), S. mirabile e S. myochrous (Dillwyn) Agardh são espécies semelhantes, cujo principal caráter que as diferencia é a espessura e estrutura da bainha. Em S. mirabile a bainha é menos espessa e apresenta lamelas paralelas a levemente divergentes, enquanto $S$. myochrous possui bainha mais espessa e com lamelas distintamente divergentes. 
Apesar dos espécimes analisados, no presente estudo, apresentarem bainhas mucilaginosas com lamelas divergentes, estes foram identificados como S. mirabile, por exibirem bainha com lamelas levemente divergentes. Sant'Anna (1984), a partir de material do estado de Minas Gerais, também observou lamelas divergentes em S. mirabile.

A espécie é considerada cosmopolita e é encontrada principalmente sobre rochas ou solos úmidos (FRÉMY, 1930; DESIKACHARY, 1959). No presente estudo, a espécie foi encontrada no banhado entre dunas, um ambiente que, em épocas de pouca chuva, pode secar por algum tempo. É a primeira ocorrência da espécie para o estado do Rio Grande do Sul.

Material examinado: HAS 104232, HAS 104234.

\section{RIVULARIACEAE Frank, 1886.}

Os membros da família formam filamentos solitários ou coloniais; filamentos e tricomas heteropolares, eretos ou prostrados, geralmente terminando em pêlo hialino; heterócitos basais obrigatórios, intercalares facultativos; ramificações falsas facultativas, formadas a partir dos heterócitos; acinetos facultativos (Calothrix), obrigatórios (Gloeotrichia) ou ausentes; zona meristemática subterminal; reprodução por hormogônio.

A principal característica que distingue Rivulariaceae das demais famílias de Nostocales são os tricomas heteropolares, intumescidos na base e atenuados no ápice, terminando em pêlo hialino (BORNET \& FLAHAULT, 1886-1888).

A divisão da família em sete gêneros (Calothrix, Dichothrix, Gardnerula, Gloeotrichia, Isactis, Rivularia e Sacconema) baseia-se nos seguintes caracteres: forma de vida, estrutura e forma do talo, tipo e frequência de ramificações falsas, morfologia da bainha mucilaginosa, habilidade de formar acinetos.

No presente estudo foram registradas três espécies pertencentes a dois gêneros de Rivulariaceae: Calothrix (2) e Gloeotrichia (1).

\section{CHAVE PARA IDENTIFICAÇÃO DOS GÊNEROS ENCONTRADOS}

1. Filamentos solitários Calothrix

1. Filamentos coloniais Gloeotrichia 


\section{Calothrix Agardh ex Bornet et Flahault, 1886-1888.}

Espécie-tipo: Calothrix confervicola Agardh ex Bornet et Flahault, Ann. Sci. nat., Sér. 7, Bot. 3, p. 349. 1886-1888.

Calothrix é um gênero que se caracteriza por desenvolver filamentos solitários ou em pequenos grupos, separados uns dos outros, dispostos mais ou menos paralelamente; bainha mucilaginosa firme, homogênea ou lamelada, incolor ou amarelada, tricomas heteropolares, constritos ou não constritos, intumescidos na base e leve ou fortemente atenuados em direção ao ápice, terminando em pelo hialino ou não; células cilíndricas ou em forma de barril; sem aerótopos; heterócitos basais obrigatórios, esféricos ou hemisféricos, intercalares facultativos, cilíndricos; acinetos raros; reprodução por hormogônios.

É um gênero perifítico, ocorrendo sobre substratos aquáticos diversos como plantas, algas ou rochas, principalmente em ambientes não poluídos. São conhecidas espécies de ambientes dulcícolas e marinhos.

Foram identificadas, no presente estudo, duas espécies de Calothrix, C. brevissima e C. scytonemicola.

\section{Chava de identificação das espécies encontradas}

1. Filamentos curtos com até $72,0 \mu \mathrm{m}$ compr. C. brevissima

1. Filamentos mais longos C. scytonemicola

Calothrix brevissima West, Journ. Linn. Soc. Bot., v. 38, p. 180. 1907.

(Fig. 23A)

Filamentos 5,0-6,7 $\mu \mathrm{m}$ diâm. na base, 37,0-72,0 $\mu \mathrm{m}$ comp.; bainha mucilaginosa incolor, firme, homogênea; tricomas constritos, levemente intumescidos na base, levemente atenuados em direção ao ápice, 27,0-40,5 $\mu \mathrm{m}$ compr.; células mais curtas que largas a isodiamétricas, 3,2-5,0 $\mu \mathrm{m}$ diâm., 3,0-4,0 $\mu \mathrm{m}$ compr.; célula apical arredondada; heterócitos basais, esféricos ou hemisféricos, 4,0-5,0 $\mu \mathrm{m}$ diâm.

Comparando as características morfológicas e métricas dos espécimes analisados com a literatura, constatou-se que a população estudada está de acordo com C. brevissima (FRÉMY, 1930; GEITLER, 1932).

Os espécimes de $C$. brevissima foram observados como epífitas de outras algas. Material examinado: HAS 104134, HAS 104147. 
Calothrix scytonemicola Tilden, Minnesota Algae, v. 1, p. 265. 1910.

(Fig. 23E)

Filamentos 8,0-10,0 $\mu \mathrm{m}$ diâm. na base; bainha mucilaginosa incolor, firme, homogênea; tricomas constritos, levemente intumescidos na base, atenuados em direção ao ápice, ápice terminando um pelo hialino; células mais curtas que largas, isodiamétricas ou

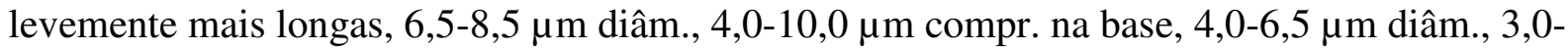
5,0 $\mu \mathrm{m}$ compr. na região mediana; heterócitos basais, esféricos, ovais ou elípticos, solitários ou aos pares, 7,0-8,5 $\mu \mathrm{m}$ diâm., 9,0-16,0 $\mu \mathrm{m}$ compr.

As populações concordam com as características de Calothrix scytonemicola, principalmente com as citadas por Compère (1974). Os espécimes foram comumente encontrados com dois heterócitos basais adjacentes, fato também observado por Compère (1974).

No presente estudo, C. scytonemicola foi observado apenas no metafíton.

Material examinado: HAS 104117, HAS 104147, HAS 104213.

\section{Gloeotrichia Agardh ex Bornet et Flahault, 1886-1888.}

Espécie-tipo: Gloeotrichia pisum Thuret ex Bornet et Flahault, Ann. Sci. nat., Sér. 7, Bot. 4, p. 366. 1886-1888.

O gênero Gloeotrichia caracteriza-se por desenvolver colônias micro ou macroscópicas, esféricas ou hemisféricas; filamentos dispostos radialmente na mucilagem; envelope mucilaginoso firme; tricoma com bainha mucilaginosa incolor, firme, homogênea ou lamelada; tricomas heteropolares, constritos ou não constritos, intumescidos na base e atenuados em direção ao ápice, terminando em pelo hialino, raramente com ramificações falsas; células em forma de barril; com ou sem aerótopos; heterócitos basais obrigatórios, esféricos ou hemisféricos, intercalares facultativos, cilíndricos; acinetos adjacentes ao heterócito, ovais ou cilíndricos; reprodução por desintegração da colônia ou por hormogônios.

O gênero apresenta ampla distribuição, ocorrendo em regiões temperadas e tropicais, no entanto, a maioria das espécies apresenta distribuição limitada. Todas as espécies são de água doce, exceto G. echinulata (Smith) Richter, que ocorrem também em ambiente salobro. Podem ser encontradas no plâncton, no perifíton e no metafíton (KOMÁREK \& HAUER, 2009). 
Gloeotrichia longicauda Schmidle, Hedwigia, p. 51. 1901.

(Figs. 24A-B, 32F)

Filamentos 8,8-9,5 $\mu \mathrm{m}$ diâm.; bainha mucilaginosa incolor, firme, homogênea; tricomas constritos, intumescidos na base, atenuados em direção ao ápice, às vezes terminando em pelo hialino, 6,0-7,2 $\mu \mathrm{m}$ diâm. na base, 4,0-6,0 $\mu \mathrm{m}$ diâm. na região mediana, até 2,0 $\mu \mathrm{m}$ diâm. no pelo; células em forma de barril, mais curtas que largas, quadráticas ou mais longas que largas, 4,8-7,2 $\mu \mathrm{m}$ compr. na base, $3,2-5,8 \mu \mathrm{m}$ compr. na região mediana, 6,5-18,5 $\mu \mathrm{m}$ compr. no pelo; conteúdo celular verde-azulado, granuloso; heterócitos basais, esféricos, ovais, oblongos, elípticos, solitários ou aos pares 5,6-7,0 $\mu \mathrm{m}$ diâm., 6,5-15,8 $\mu \mathrm{m}$ compr.

Comparando as características morfológicas e métricas dos espécimes analisados com a literatura, constatou-se que a população estudada está de acordo com G. longicauda (GEITLER, 1932), embora não tenham sido observados acinetos.

Gloeotrichia longicauda foi observada apenas no plâncton, apesar da espécie ser característica do perifíton, fato comentado também por Geitler (1932).

Material examinado: HAS 104124, HAS 104125.

\section{MICROCHAETACEAE Lemmermann, 1907.}

Microchaetaceae é considerada por Komárek \& Anagnostidis (1989), intermediária entre as famílias Scytonemataceae e Rivulariaceae, pois desenvolve filamentos heteropolares, ramificações falsas começando no heterócito e células apicais arredondadas.

A família é caracterizada por apresentar filamentos solitários ou em colônias cespitosas, às vezes aderidas ao substrato; bainha mucilaginosa incolor, firme, homogênea ou lamelada; tricomas heteropolares, constritos ou não constritos, não atenuados, raramente com ramificações falsas; células cilíndricas; heterócitos basais obrigatórios, esféricos ou hemisféricos, intercalares cilíndricos; acinetos facultativos, solitários ou em fileira, cilíndricos; zona meristemática subpolar ou polar; reprodução por desintegração do filamento ou por hormogônios.

A família é composta por oito gêneros, Camptylonemopsis, Coleodesmium, Coleodesmiumopsis, Fortiea, Hassallia, Microchaete, Petalonema e Tolypothrix, baseado principalmente na estrutura do talo, da bainha mucilaginosa e no tricoma. 


\section{Microchaete Thuret ex Bornet et Flahault, 1887.}

Espécie-tipo: Microchaete grisea Thuret ex Bornet et Flahault, Ann. Sci. Nat. Bot., Sér. 7, v. 5, p. 83. 1887.

Microchaete carateriza-se por apresentar filamentos solitários ou em pequenos grupos, aderidos ao substrato; bainha mucilaginosa incolor, firme, fina ou espessa, homogênea ou lamelada, usualmente incolor; tricomas heteropolares, cilíndricos ou levemente atenuados em direção ao ápice, constritos ou não constritos; raramente com ramificações falsas; células isodiamétricas, mais curtas ou mais longas que largas, cilíndricas, raramente em forma de barril; célula apical arredondada; sem aerótopos; zona meristemática apical; heterócitos basais obrigatórios, esféricos ou hemisféricos, intercalares facultativos, cilíndricos; acinetos facultativos, solitários ou em fileiras; reprodução por hormogônios.

O gênero apresenta ampla distribuição, ocorrendo tanto em regiões temperadas como em regiões tropicais. A maioria das espécies é epífita em algas e plantas aquáticas, poucas espécies são epilíticas, ocorrendo em ambientes de água doce lóticos ou em lagoas costeiras ou marinhas (KOMÁREK \& HAUER, 2009).

Microchaete violaceae foi a única espécie do gênero Microchaete resgitrada no presente trabalho.

Microchaete violacea Frémy, Myx. D’Afr. équat.franc., 3, p. 284. 1930.

(Fig. 23B-D)

Filamentos retos ou curvos, 10,0-16,0 $\mu \mathrm{m}$ diâm.; bainha mucilaginosa incolor, firme, homogênea; tricomas constritos; células mais longas que largas, 7,0-13,0 $\mu \mathrm{m}$ diâm., 10,0-18,0 $\mu$ m compr.; conteúdo celular verde azulado, homogêneo ou granuloso; heterócitos basais ou intercalares, esféricos ou cilíndricos, 9,0-13,0 $\mu \mathrm{m}$ diâm., 8,0-40,0 $\mu \mathrm{m}$ compr.; acinetos em fileiras (6-10), cilíndricos, 11,0-13,0 $\mu \mathrm{m}$ diâm., 12,0-26,0 $\mu \mathrm{m}$ compr.

Microchaete catenata Lemmermann, M. tenera Thuret e M. violacea Frémy são três espécies morfologicamente muito semelhantes aos espécimes analisados. Dentre as três, $M$. tenera é a que apresenta filamentos mais estreitos $(6,0-7,0 \mu \mathrm{m})$. M. catenata e $M$. violacea exibem filamentos com valores métricos que se sobrepõem (9,0-12,0 e 12,0-12,5 $\mu \mathrm{m}$ diâm., respectivamente). Segundo Frémy (1930) as duas espécies diferem pelo diâmetro do filamento e do tricoma, além da forma dos acinetos, que são em forma de barril em $M$. catenata e cilíndricos em $M$. violacea.

As populações observadas apresentaram ampla variação quanto às características métricas do filamento e do tricoma, coincidindo com ambas as espécies. 
Assim, baseado principalmente nas características métricas dos tricomas e na forma dos acinetos, que se mostraram sempre cilíndricos, os espécimes analisados foram identificados como $M$. violacea.

Material examinado: HAS 104117, HAS 104124, HAS 104125, HAS 104127, HAS 104134, HAS 104147, HAS 104174, HAS 104213, HAS 104431.

\section{NOSTOCACEAE Dumort, 1829.}

Nostocaceae é uma família morfologicamente bem definida. Caracteriza-se por apresentar filamentos solitários ou em colônias mucilaginosas; mucilagem incolor ou colorida, firme, margem difluente ou evidente, homogênea ou lamelada; tricomas isopolares, constritos ou não constritos, atenuados ou não atenuados, sem ramificações; células cilíndricas, em forma de barril, esféricas ou cilíndricas; heterócitos e acinetos presentes; sem zona meristemática; reprodução por hormogônios ou hormocitos.

A família se destaca dentro de Nostocales pelo maior número de gêneros. Segundo Komárek \& Anagnostidis (1989), Nostocaceae abrange 14 gêneros, divididos em duas subfamílias, Anabaenoideae e Nostocoideae, baseado principalmente na direção do desenvolvimento dos acinetos em relação aos heterócitos.

$\mathrm{Na}$ subfamília Anabaenoideae, os acinetos desenvolvem-se em direção oposta ao heterócito, a partir de uma única ou através da fusão de várias células vegetativas, estando estas juntas ao heterócito ou distantes. Este tipo de desenvolvimento dos acinetos é denominado paraheterocítico e está presente nos gêneros Anabaena, Anabaenopsis, Aphanizomenon, Cylindrospermopsis, Cylindrospermum, Hydrocoryne, Raphidiopsis, Richelia e Wollea.

Na subfamília Nostocoideae, os acinetos são denominados apoheterocíticos, pois se originam a partir de uma célula vegetativa equidistante de dois heterócitos e a transformação das demais células ocorrem em direção aos heterócitos, formando uma fileira de acinetos. Os gêneros que constituem essa subfamília são Aulosira, Isocystis, Nodularia, Nostoc e Trichormus.

Além do tipo de formação dos acinetos, outras características são importantes na classificação dos gêneros dentre de Nostocaceae, tais como: morfologia (simetria) dos filametos, que depende da posição dos heterócitos no tricoma (simétrico, subsimétrico ou 
metamérico); posição dos acinetos ou sua ausência no tricoma; morfologia das células vegetativas; formação de colônias ou filamentos solitários; morfologia da bainha mucilaginosa; morfologia de heterócitos e acinetos; presença ou ausência de aerótopos.

Muitas mudanças estão ocorrendo quanto à classificação tradicional dos gêneros de Nostocaceae. Estudos moleculares vêm mostrando que gêneros como Anabaena, Aphanizomenon, Trichormus, Nostoc não são monofiléticos (RAJANIEMI et al., 2005 ) e dando suporte para a criação de novos gêneros: Cuspidothrix (RAJANIEMI et al. 2005b), Macrospermum (KOMÁREK, 2008), Dolichospermum (WACKLIN et al. 2009).

No presente estudo, foram identificadas 16 espécies pertencentes a oito gêneros: Anabaena (3), Aulosira (1), Cuspidothrix (1), Cylindrospermopsis (1), Cylindrospermum (1), Dolichospermum (6), Hydrocoryne (1) e Nostoc (2).

\section{CHAVE PARA IDENTIFICAÇÃO DAS SUBFAMÍLIAS ENCONTRADAS}

1. Acinetos paraheterocíticos Anabaenoideae

1. Acinetos apoheterocíticos Nostocoideae

Subfamília Anabaenoideae (Bornet et Flahault) Kirchner, 1900.

\section{CHAVE PARA IDENTIFICAÇÃO DOS GÊNEROS ENCONTRADOS}

1. Heterócitos terminais

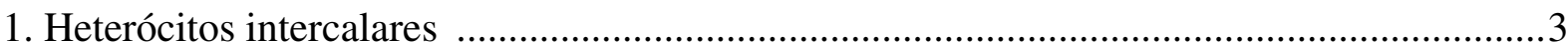

2. Acinetos contíguos aos heterócitos Cylindrospermum

2. Acinetos distantes dos heterócitos Cylindrospermopsis

3. Heterócitos subsimétricos Cuspidothrix

3. Heterócitos metaméricos 4

4. Filamentos com dois ou mais tricomas Hydrocoryne

4. Filamentos com somente um tricoma

5. Células com aerótopos Dolichospermum

5. Células sem aerótopos Anabaena 


\section{Anabaena Bory ex Bornet et Flahault, 1886-1888.}

Espécie-tipo: Anabaena oscillarioides Bory ex Bornet et Flahault, Ann. Sci. nat., Sér. 7, Bot. 7, p. 233. 1886-1888.

De acordo com Geitler (1932), os gêneros Anabaena e Aphanizomenon são próximos e a estrutura do tricoma é a principal característica que distingue os dois gêneros. Enquanto os tricomas de Anabaena podem ser levemente atenuados ou não atenuados, os de Aphanizomenon apresentam células apicais nitidamente atenuadas, alongadas e hialinas.

Os dois gêneros, segundo Komárek \& Anagnostidis (1989), são facilmente distinguíveis um do outro, quando comparadas suas espécies-tipo, Anabaena oscillarioides e Aphanizomenon flos-aquae. No entanto, os dois gêneros apresentam espécies com morfologias intermediárias.

Segundo Komárek \& Anagnostidis (1989), Anabaena é dividido em dois subgêneros, com base no modo de vida (planctônico ou perifítico) e na habilidade de produzir aerótopos: Anabaena, caracterizado por apresentar filamentos solitários ou formando "mats" sobre o substrato, flutuantes ou edáficos, mais ou menos curvos ou irregularmente flexuosos, não atenuados ou levemente atenuados em direção à extremidade; células apicais arredondadas ou cônico-arredondadas; sem aerótopos; e Dolichospermum, caracterizado por desenvolver tricomas solitários ou em grupos, planctônicos, mais ou menos retos, regular ou irregularmente espiralados, não atenuados ou levemente atenuados em direção à extremidade; aerótopos obrigatórios.

Tradicionalmente, o gênero Anabaena é bastante diverso, distribuído ao redor do mundo, em uma variedade de hábitats e abrange um grande número de espécies.

Recentemente, estudo moleculares com o gene RNAr 16S mostraram que o gênero Anabaena sensu Bornet et Flahault é heterogêneo: as espécies bentônicas de Anabaena formam "mats" e não possuem aerótopos, constitum um grupo geneticamente distinto das espécies planctônicas, que exibem tricomas solitários ou em pequenos grupos e aerótopos obrigatórios (GUGGER et al., 2002ª ,b; RAJANIEMI et al., 2005a ,b; WILLAME et al., 2006). Devido à diferença genética entre as espécies bentônicas e planctônicas de Anabaena, as planctônicas foram classificadas no novo gênero Dolichospermum.

Assim, o gênero Anabaena caracteriza-se por desenvolver filamentos solitários ou em grupos micro ou macroscópicos, com tricomas emaranhados ou dispostos paralelamente; tricomas metaméricos, não atenuados ou levemente atenuados em direção ao ápice, constritos, sem bainha mucilaginosa, mas às vezes com envelope mucilaginoso; envelope mucilaginoso hialino, incolor, difluente; células cilíndricas, em forma de barril ou esféricas, mais curtas ou 
mais longas que largas; conteúdo celular homogêneo ou granuloso; sem aerótopos; célula apical alongada, cônico-arredondada ou esférica; heterócitos esféricos, ovais ou cilíndricos; acinetos esféricos, ovais ou cilíndricos, solitários ou em fileiras, intercalares, próximos aos heterócitos; reprodução através da fragmentação do tricoma, usualmente a partir do heterócito ou através de acinetos.

No presente estudo foram identificadas três espécies de Anabaena: A. inaequalis, A. oscillarioides e A. sphaerica.

\section{Chave de identificação das espécies encontradas}

1. Tricomas com acinetos esféricos A. sphaerica

1. Tricomas com acinetos não esféricos .2

2. Acinetos distantes do heterócito A. inaequalis

2. Acinetos adjacentes ao heterócito A. oscillarioides

Anabaena inaequalis (Kützing) Bornet et Flahault, Ann. Sci. nat. Sér. 7, Bot. 7, p. 231. 18861888.

(Figs. 25A, 32G)

Tricomas solitários, retos ou curvos, não atenuados, sem envelope mucilaginoso; células em forma de barril, 4,2-5,0 $\mu \mathrm{m}$ diâm., 3,0-5,0 $\mu \mathrm{m}$ compr.; células apicais esféricas ou cônico-arredondadas; conteúdo celular verde-azulado, granuloso, sem aerótopos; heterócitos esféricos ou levemente alongados, 4,5-7,5 $\mu \mathrm{m}$ diâm., 4,5-10,0 $\mu \mathrm{m}$ compr.; acinetos cilíndricos, solitários ou aos pares, distantes dos heterócitos, 5,0-8,5 $\mu \mathrm{m}$ diâm., 8,0-19,0 $\mu \mathrm{m}$ compr.

Em A. inaequalis, os tricomas planctônicos são agregados e dispõem-se paralelamente. Embora, na área estudada, tenham sido observados apenas tricomas solitários, os espécimes foram identificados como A. inaequalis por apresentarem as demais características referidas para a espécie: tricomas com células em forma de barril, heterócitos esféricos a quadráticos e acinetos cilíndricos (BORNET \& FLAHAULT, 1886-1888; FRÉMY, 1930).

Em outras populações estudadas também foram observadas tricomas solitários, como nos estados de São Paulo (SANT'ANNA, 1991), do Rio Grande do Sul (WERNER, 2002) e na Argentina (GUARRERA et al., 1968).

As espécies identificadas como A. inaequalis foram encontradas apenas no plâncton. Material examinado: HAS 104134, HAS 104174, HAS 104220, HAS 104227. 
Anabaena oscillarioides Bory ex Bornet et Flahault, Ann. Sci. nat. Sér. 7, Bot. 7, p. 233. 1886-1888.

(Fig. 25B)

Tricomas solitários, retos ou levemente curvos, não atenuados, sem envelope mucilaginoso; células em forma de barril a alongadas, 4,0-6,0 $\mu \mathrm{m}$ diâm., 3,5-8,0 $\mu \mathrm{m}$ compr.; células apicais quadráticas; conteúdo celular verde-azulado, homogêneo ou levemente granuloso; sem aerótopos; heterócitos quadráticos a cilíndricos, 6,0-8,0 $\mu \mathrm{m}$ diâm., 10,0-14,0 $\mu \mathrm{m}$ compr.; acinetos oblongos, solitários ou aos pares, junto aos heterócitos, 9,0-15,0 $\mu \mathrm{m}$ diâm., 12,0-25,5 $\mu \mathrm{m}$ compr.

Anabaena oscillarioides é uma espécie caracterizada pelos tricomas retos, células vegetativas cilíndricas e acinetos dispostos em ambos os lados do heterócito.

Os espécimes analisados, no presente estudo, apresentaram as características citadas acima, tendo sido identificados como A. oscillarioides, embora tenham exibido dimensões celulares que variaram desde valores inferiores aos referidos para a espécie por Geitler (1932).

Anabaena oscillarioides é morfologicamente semelhante a A. cylindrica Lemmermann e A. subcylindrica Borge, no entanto A. cylindrica possui tricomas mais estreitos (3,0-4,0 $\mu \mathrm{m})$ e A. subcylindrica possui células cilíndricas e tricomas com pequena variação no diâmetro (GEITLER, 1932). Além disso, esse mesmo autor comenta que A. cylindrica e $A$. subcylindrica ocorrem em regiões temperadas.

A espécie já foi registrada ocorrendo na América do Sul: Venezuela (YACUBSON, 1969) e na Argentina (GUARRERA, 1977).

$\mathrm{Na}$ área estudada, A. oscillarioides foi registrada apenas no plâncton.

Material examinado: HAS 104093, HAS 104134.

Anabaena sphaerica Bornet et Flahault, Ann. Sci. nat. Sér. 7, Bot. 7, p. 228. 1888.

(Fig. 25C-D)

Tricomas solitários, retos ou levemente curvos, não atenuados, sem envelope mucilaginoso; células em forma de barril ou esféricas, 5,0-6,0 $\mu \mathrm{m}$ diâm., 4,5-7,2 $\mu \mathrm{m}$ compr.; células apicais esféricas; conteúdo celular verde-azulado, granuloso, sem aerótopos; heterócitos esféricos, 6,0-7,0 $\mu \mathrm{m}$ diâm.; acinetos esféricos, em ambos os lados do heterócito, 8,0-14,0 $\mu \mathrm{m}$ diâm., 9,0-15,0 $\mu \mathrm{m}$ compr. 
Os espécimes apresentam características morfológicas e métricas que concordam com as referidas para A. sphaerica (BORNET \& FLAHAULT, 1886-1888), que apresenta tricomas não espiralados com acinetos esféricos, dispostos em ambos os lados do heterócito.

A espécie já foi encontrada no Brasil (DROUET, 1938; SENNA, 1982; SANT'ANNA, 1991; DE-LAMONICA-FREITE \& HECKMAN, 1996), mas o presente estudo constitui o primeiro registro para o estado do Rio Grande do Sul.

Material examinado: HAS 104134, HAS 104366.

\section{Cuspidothrix Rajaniemi et al., 2005}

Espécie-tipo: Cuspidothrix issatschenkoi (Usacev) Rajaniemi et al., Algolog. Stud., v. 117, p. 388. 2005

O gênero Cuspidothrix foi proposto a partir da separação de um grupo de espécies descritas originalmente no gênero Aphanizomenon e que são geneticamente diferentes deste.

Tradicionalmente, o gênero Aphanizomenon é considerado heterogêneo e caracterizado por apresentar tricomas atenuados em direção às extremidades, com células apicais alongadas, mais ou menos hialinas.

Komárek \& Kovácik (1989) organizaram as espécies que compunham o gênero Aphanizomenon em três grupos em função das características da célula apical. O primeiro, composto pelas espécies que exibem células apicais alongadas, cilíndrico-arredondadas, não pigmentadas e hialinas, e inconspicuamente atenuados; o segundo, pelas espécies com tricomas gradualmente atenuados, tornando-se bruscamente atenuados nas extremidades, com células apicais alongadas, cônicas, pontiagudas, geralmente não pigmentadas e hialinas; e o terceiro, formado pelas espécies que desenvolvem tricomas são gradualmente atenuados, cujas células apicais apresentam o mesmo comprimento que as demais células vegetativas.

Posteriormente, Rajaniemi et al. (2005b), a partir de estudos com o gene RNAr 16S, propuseram a criação do gênero Cuspidothrix, formado pelas espécies do segundo grupo citado acima, por este ser geneticamente diferente das demais espécies de Aphanizomenon.

Assim, Cuspidothrix caracteriza-se por apresentar tricomas solitários, flutuantes, curtos ou longos, retos ou curvos, raramente espiralados, cilíndricos, levemente constritos a não constritos, sem bainha mucilaginosa, raramente com envelope mucilaginoso fino, atenuados em direção ao ápice; células cilíndricas, isodiamétricas ou mais longas que largas; conteúdo celular finamente granuloso; aerótopos facultativos; células apicais alongadas, atenuadas, cônicas, pontiagudas, hialinas; heterócitos intercalares, solitários, cilíndricos ou 
elípticos; acinetos intercalares, solitários ou aos pares, alongados, mais ou menos cilíndricos, distantes do heterócito.

O gênero está presente tanto em regiões tropicais como em regiões temperadas e é composto por cinco espécies, todas planctônicas (KOMÁREK \& KOMÁRKOVÁ, 2006).

Cuspidothrix issatschenkoi (Usacev) Rajaniemi et al., Algolog. Stud., v. 117, p. 388. 2005

Basônimo: Aphanizomenon issatschenkoi Usacev, Mat. Gidrobiol. Litol. Kasp. Morja, 109. 1938.

(Figs. 26A, 33B)

Tricomas solitários, retos ou curvos, levemente constritos, bruscamente atenuados nas extremidades, 2,4-3,8 $\mu \mathrm{m}$ diâm; células cilíndricas, 4,0-12,0 $\mu \mathrm{m}$ compr.; células apicais pontiagudas, hialinas, 1,2-2,2 8,0-11,0 $\mu \mathrm{m}$ diâm., 9,0-22,0 $\mu \mathrm{m}$ compr.; conteúdo verdeazulado, granuloso ou não; com ou sem aerótopos; heterócitos cilíndricos, 3,2-4,8 $\mu$ m diâm., 6,0-9,5 $\mu \mathrm{m}$ compr.; acinetos não observados.

De acordo com Komárek \& Komárková (2006), C. issatschenkoi apresenta tricomas atenuados e células apicais alongadas, cônicas e hialinas, as células são cilíndricas e os acinetos são cilíndricos e se formam distantes dos heterócitos. As populações observadas estão de acordo com os autores, exceto pelo fato de não terem sido observados acinetos.

Cuspidothrix issatschenkoi é morfologicamente muito semelhante a C. capricorni, mas esta última apresenta acinetos ovais próximos ao heterócito e células apicais bruscamente atenuadas, enquanto a primeira forma acinetos cilíndricos distantes do heterócito e células apicais cuja atenuação é menos acentuada que em $C$. capricorni. As populações analisadas foram identificadas como $C$. issatschenkoi, com base nas características morfológicas citadas acima, principalmente na morfologia da célula apical.

Material examinado: HAS 104103, HAS 104132, HAS 104163, HAS 104167, HAS 104343, HAS 104348, HAS 104351, HAS 104352, HAS 104381.

\section{Cylindrospermopsis (Wolosynska) Seenayya et Subba Raju, 1972.}

Espécie-tipo: Cylindrospermopsis raciborskii (Wolosinska) Seenayya et Suba Raju, In: Desikachary, Taxonomy and biology of blue-green algae p. 55-57. 1972.

O gênero Cylindrospermopsis caracteriza-se por apresentar tricomas solitários, retos, curvos ou espiralados, não atenuados a levemente atenuados em direção ao ápice, sem bainha mucilaginosa, subsimétrico, constritos ou não; células cilíndricas ou em forma de barril, mais longas que largas; aerótopos facultativos; células apicais atenuadas; heterócitos terminais, 
ovais ou cônicos, às vezes levemente curvos; acinetos cilíndricos ou elípticos, distantes do heterócito; reprodução através da fragmentação do tricoma ou pelos acinetos.

Todas as espécies de Cylindrospermopsis são planctônicas de ambientes eutrofizados de água doce em regiões tropicais, subtropicais e temperadas onde, às vezes, formam florações (KOMÁREK \& KOMÁRKOVÁ, 2003).

Dentre as espécies do gênero, somente $C$. raciborskii foi registrada na área estudada.

Cylindrospermopsis raciborskii (Wolosynska) Seenayya et Subba Raju, In: Desikachary, Taxonomy and biology of blue-green algae p. 55-57. 1972.

Basônimo: Anabaena raciborskii Wolosynska, Bull. int. Acad. Sci. Lett. Cracovie. Ser. B., 1912, p. 684. 1913.

(Figs. 26B, 33A)

Tricomas solitários, retos ou curvos, 97,0-428,0 $\mu \mathrm{m}$ compr., não constritos a levemente constritos, atenuados nas extremidades, sem envelope mucilaginoso, 2,0-2,8 $\mu \mathrm{m}$ diâm; células cilíndricas, 1,5-6,3 vezes mais longas que largas, 4,0-12,5 $\mu \mathrm{m}$ compr.; células apicais pontiagudas, cônico-arredondadas ou cilíndrico-arredondadas; conteúdo verdeazulado, homogêneo, com aerótopos; heterócitos terminais, solitários, cônicos ou cônicoalongados, 2,2-3,0 $\mu \mathrm{m}$ diâm., 6,5-9,5 $\mu \mathrm{m}$ compr.; acinetos cilíndricos, arredondados nas extremidades ou ovais, intercalares, distantes 2-3 células das extremidades, 2,7-4,0 $\mu \mathrm{m}$ diâm., 7,0-16,5 $\mu \mathrm{m}$ compr.

Cylindrospermopsis raciborskii foi descrita como Anabaena raciborskii, sendo posteriormente transferida para Anabaenopsis por apresentar heterócitos terminais. No entanto, a origem dos heterócitos terminais de Anabaenopsis raciborskii é diferente da origem dos heterócitos das outras espécies de Anabaenopsis.

A espécie foi originalmente descrita para região tropical, mas, atualmente, observa-se florações também em regiões temperadas, demonstrando sua alta capacidade de adaptação e vantagem competitiva, possibilitando a rápida expansão em diferentes regiões da Terra.

Cylindrospermopsis raciborskii é considerada cosmopolita e, segundo Padisák (1997), é uma espécie invasora e apresenta um amplo intervalo de tolerância ecofisiológica, pois já foi encontrada em ambientes oligotróficos até corpos d'água hipereutróficos, tanto em regiões tropicais como em regiões temperadas, em ambientes lóticos e lênticos, de água doce a levemente salinos.

Segundo Padisák (1997), o sucesso ecológico da espécie está relacionado com fatores como tolerância à baixa luminosidade, alta capacidade de absorção de amônia e fósforo; 
capacidade de migração na coluna d'água; fixação de nitrogênio atmosférico, alta capacidade de dispersão, através de acinetos resistentes.

Cylindrospermopsis raciborskii constitui uma espécie de grande importância ecológica, principalmente por ser uma espécie tóxica, produtora de hepatotoxinas, neurotoxinas e formar florações. Padisák (1997) comentou que florações desta espécie, geralmente não formam manchas na superfície da água. No entanto, relatos de outras florações mostram formação de manchas que variam de coloração (verde-amarelada, avermelhada, esverdeada).

Florações tóxicas, com morte de peixes e outros animais, são relacionadas à espécie. O caso mais expressivo ocorreu na Austrália, onde 148 pessoas foram hospitalizadas, após consumirem água contaminada com toxinas produzidas pela espécie (HAWKINS et al., 1985).

A espécie apresenta grande diversidade morfológica, podendo apresentar tricomas retos, sigmoides ou espiralados com características métricas variadas (KOMÁRKOVÁ et al., 1999; SAKER et al., 1999; BITTENCOURT-OLIVEIRA \& MOLICA, 2003).

No presente estudo, C. raciborskii foi observada apenas no plâncton.

Material examinado: HAS 104132, HAS 104343, HAS 104352.

\section{Cylindrospermum Kützing ex Bornet et Flahault, 1886-1888.}

Espécie-tipo: Cylindrospermum stagnale Kützing ex Bornet et Flahault, Ann. Sci. nat. Sér. 7, Bot. 7, p. 250. 1886-1888.

O gênero Cylindrospermum caracteriza-se por apresentar talos mucosos ou filamentosos; tricomas curvos, cilíndricos ou levemente estreitos no meio, constritos, sem bainha mucilaginosa, mas com envelope mucilaginoso fino, incolor, homogêneo, difluente; células cilíndricas, mais ou menos isodiamétricas ou mais longas que largas, raramente em forma de barril; conteúdo celular homogêneo ou granuloso; aerótopos ausentes; heterócitos terminais, esféricos, ovais ou cônicos em ambas as extremidades do tricoma; acinetos contíguos aos heterócitos em ambas as extremidades do tricoma, raramente esféricos, normalmente ovais ou cilíndricos, solitários ou em fileiras; reprodução por fregmentação do tricoma em hormogônios ou pelos acinetos.

Cylindrospermopsis também apresenta heterócitos terminais como Cylindrospermum, no entanto, este não apresenta aerótopos; os tricomas de Cylindrospermum, sem heterócitos e acinetos, não são atenuados e os ápices são arredondados, enquanto que os tricomas de Cylindrospermopsis são atenuados e/ou pontiagudos; em Cylindrospermum os acinetos se 
desenvolvem adjacentes aos heterócitos, enquanto que em Cylindrospermopsis os acinetos se desenvolvem próximos aos heterócitos.

A maioria das espécies do Cylindrospermum são perifíticas, mas também podem ser encontradas na comunidade bentônica ou metafítica. São encontradas em ambientes não poluídos a levemente eutrofizados (KOMÁREK \& HAUER, 2009).

$\mathrm{Na}$ área estudada, foi registrada apenas a espécie Cylindrospermum mucicola.

Cylindrospermum muscicola Kützing, Phyc. Germ., p. 173. 1845.

(Fig. 26C-D)

Tricomas emaranhados, flexuosos ou curvos, constritos, 3,2-4,0 $\mu \mathrm{m}$ diâm; células quadráticas a cilíndricas, 4,0-6,0 $\mu \mathrm{m}$ compr.; conteúdo verde-azulado, homogêneo ou granuloso; sem aerótopos; heterócitos esféricos ou oblongos, 4,0-6,0 $\mu \mathrm{m}$ diâm., 5,0-8,0 $\mu \mathrm{m}$ compr.; acinetos ovais, elípticos ou cilíndricos com extremidades arredondadas, solitários, 10,0-13,0 $\mu \mathrm{m}$ diâm., 17,0-24,0, episporo liso, inicialmente incolor, tornando-se verde escuro.

Cylindrospermum muscicola caracteriza-se por apresentar acinetos largamente ovais, com episporo liso. Dentre as espécies do gênero, $C$. licheniforme Kützing e $C$. stagnale Kützing são as que mais se assemelham a C. muscicola. Segundo Geitler (1932), as duas espécies apresentam células vegetativas com forma e características métricas semelhantes, no entanto, $C$. stagnale exibe acinetos cilíndricos e, tanto $C$. stagnale como $C$. licheniforme, apresentam acinetos mais longos (32,0-40,0 e 20,0-30,0, respectivamente) que os referidos para C. muscicola.

Baseado nas características morfológicas e métricas, bem como no tipo de ambiente em que a espécie ocorre, a população foi identificada como C. muscicola.

Material examinado: HAS 104117, HAS 104125, HAS 104131, HAS 104174.

\section{Dolichospermum Wacklin et al., 2009.}

Espécie-tipo: Dolichospermum flos-aquae ([Lyngbye] Brébisson ex Bornet et Flahault) Wacklin et al., Fottea, v. 9, n. 1, p. 60. 2009.

Dolichospermum caracteriza-se por apresentar filamentos solitários ou em pequenos grupos; tricomas retos, flexuosos, regular ou irregularmente espiralados, constritos, metaméricos; envelope mucilaginoso presente ou ausente, incolor, homogêneo, difluente; células cilíndricas, em forma de barril ou esféricas; conteúdo celular homogêneo ou granuloso; aerótopos obrigatórios; células apicais semelhantes às demais células vegetativas; heterócitos, geralmente solitários, esféricos, ovais ou cilíndricos, usualmente maiores que as 
células vegetativas; acinetos esféricos, ovais ou cilíndricos, solitários ou em fileiras pequenas, intercalares; reprodução através da fragmentação do tricoma ou através de acinetos.

Originalmente, as espécies que compõem Dolichospermum foram descritas em Anabaena subgen. Dolichospermum. Mas, recentemente, estudos moleculares com o gene RNAr 16S mostraram que Anabaena subgen. Dolichospermum é um grupo geneticamente distinto do restante das espécies de Anabaena (GUGGER et al., 2002a,b; RAJANIEMI et al., 2005a,b) e foi elevado a gênero por Wacklin et al. (2009).

No presente estudo foram registradas seis espécies de Dolichospermum.

\section{Chave de identificação para as espécies encontradas}

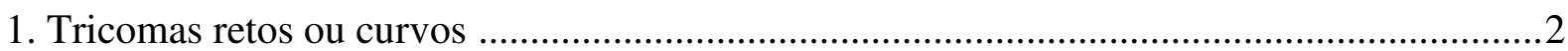

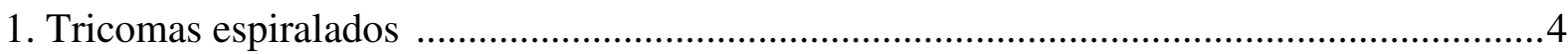

2. Tricomas sem envelope mucilaginoso …....................................................... D. viguieri

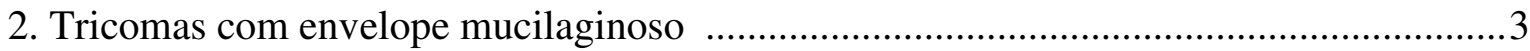

3. Tricomas 7,5-9,0 $\mu \mathrm{m}$ diâm. ................................................................... D. cf. solitarium

3. Tricomas 10,0-14,0 $\mu \mathrm{m}$ diâm. ................................................................... D. planctonicum

4. Tricomas com espiras irregulares, 3,8-5,0 $\mu \mathrm{m}$ diâm., sem envelope mucilaginoso D. flos-aquae

4. Tricomas com espiras regulares, maiores que 7,5 $\mu \mathrm{m}$ diâm., com envelope mucilaginoso

5. Diâmetro da espira 49,0-57,0 $\mu \mathrm{m}$, células 10,0-12,5 $\mu$ m diâm. D. crassum

5. Diâmetro da espira 35,0-47,0 $\mu \mathrm{m}$, células 7,5-10,0 $\mu \mathrm{m}$ diâm.

D. spiroides

\section{ESPÉCIES COM TRICOMAS ESPIRALADOS}

Dolichospermum crassum (Lemmermann) Wacklin, Hoffmann et Komárek, Fottea, v. 9, n. 1, p. 61. 2009.

Basônimo: Anabaena spiroides var. crassa (Lemmermann), Komárková-Legnerová et Cronberg, Algolog. Stud., v. 67, p. 24. 1992.

(Figs. 27B, 33F-G)

Tricomas solitários, espiralados, com envelope mucilaginoso; espiras regulares, 49,057,0 $\mu \mathrm{m}$ diâm., 20,0-35,0 $\mu \mathrm{m}$ distantes umas das outras; células em forma de barril ou esféricas, 10,0-12,5 $\mu \mathrm{m}$ diâm., 8,0-12,0 $\mu \mathrm{m}$ compr.; células apicais esféricas; conteúdo celular verde-acastanhado; heterócitos esféricos ou achatados nos pólos, 8,0-11,0 $\mu \mathrm{m}$ diâm., 7,0-10,5 
$\mu \mathrm{m}$ compr.; acinetos elípticos, solitários, distantes dos heterócitos, 12,5-15,0 $\mu \mathrm{m}$ diâm., 18,0$23,5 \mu \mathrm{m}$ compr.

A identificação das espécies espiraladas do gênero Dolichospermum é baseada principalmente na amplitude da torção da espira, na morfologia e dimensões celulares, tanto vegetativas como dos heterócitos e acinetos e na disposição dos heterócitos e acinetos no tricoma.

Dolichospermum crassum é caracterizada por apresentar tricomas regularmente espiralados e envelope mucilaginoso espesso (KOMÁRKOVÁ-LEGNEROVÁ \& CRONBERG, 1992; KOMÁRKOVÁ-LEGNEROVÁ \& ELORANTA, 1992). Além de D. crassum, D. spiroides (Klebahn) Wacklin et al. também apresenta essas características e as principais diferenças entre essas duas espécies são as dimensões celulares e das espiras, bem como a espessura do envelope mucilaginoso, que são maiores em D. crassum.

Embora D. crassum e D. circinalis (Rabenhost ex Bornet et Flahault) Wacklin et al. possuam dimensões celulares que se sobrepõem, o diâmetro das espiras são maiores em $D$. circinalis e mais regulares em D. crassum (KOMÁRKOVÁ-LEGNEROVÁ \& CRONBERG, 1992).

Os espécimes observados foram identificados como $D$. crassum por apresentarem as características morfológicas e métricas que estão de acordo com a literatura consultada.

Material examinado: HAS 104369, HAS 104396.

Dolichospermum flos-aquae ([Lyngbye] Brébisson ex Bornet et Flahault) Wacklin, Hoffmann et Komárek, Fottea, v. 9, n. 1, p. 60. 2009.

Basônimo: Anabaena flos-aquae (Lyngbye) Brébisson ex Bornet et Flahault, Ann. Sci. Bot., Sér. 7, p. 228. 1888.

(Figs. 27A, 33D)

Tricomas solitários, irregularmente espiralados, sem envelope mucilaginoso; espiras irregulares; células esféricas ou em forma de barril, 3,8-5,0 $\mu \mathrm{m}$ diâm., 5,0-7,0 $\mu \mathrm{m}$ compr.; células apicais esféricas; conteúdo celular verde-azulado; heterócitos esféricos, 4,0-6,0 $\mu \mathrm{m}$ diâm.; acinetos ovais a elípticos, levemente curvos, solitários, distantes dos heterócitos, 6,011,5 $\mu \mathrm{m}$ diâm., 15,0-19,8 $\mu \mathrm{m}$ compr.

Dolichospermum flos-aquae caracteriza-se por apresentar tricomas com espiras irregulares, células em forma de barril ou esféricas e acinetos curvos e solitários.

É considerada uma espécie cosmopolita, comum em reservatórios eutróficos. 
A disposição da torção das espiras apresentou-se bastante variável na população analisada, sendo sempre irregulares. A população apresentou características morfológicas e métricas que estão de acordo com as referidas para D. flos-aquae por Geitler (1932) e Komárek \& Zapomelová (2007).

Material examinado: HAS 104242.

Dolichospermum spiroides (Klebahn) Wacklin, Hoffmann et Komárek, Fottea, v. 9, n. 1, p. 62. 2009.

Basônimo: Anabaena spiroides Klebahn, Flora 80, p. 26. 1895.

(Figs. 27C, 33E)

Tricomas solitários, espiralados, com envelope mucilaginoso; espiras regulares, 35,047,0 $\mu \mathrm{m}$ diâm., 28,0-34,5 $\mu \mathrm{m}$ distantes umas das outras; células esféricas, 7,5-10,0 $\mu \mathrm{m}$ diâm., 7,0-10,0 $\mu \mathrm{m}$ compr.; células apicais esféricas; conteúdo celular verde-azulado; heterócitos esféricos ou achatados nos pólos, 8,0-14,0 $\mu \mathrm{m}$ diâm., 8,0-11,5 $\mu \mathrm{m}$ compr.; acinetos não observados.

Os espécimes observados apresentam características morfológicas e métricas que estão de acordo com os citados na literatura consultada (GEITLER, 1932; DESIKACHARY, 1959).

Os espécimes identificados como $D$. spiroides diferem dos identificados como $D$. crassum por apresentarem dimensões celulares inferiores, envelope mucilaginoso menos espesso e tricomas com espiras menos regulares.

Considerando as variações métricas das células vegetativas, D. circinalis (Rabenhorst ex Bornet et Flahault) Wacklin et al. e D. spiroides apresentam valores que se sobrepõem, no entanto, D. circinalis apresenta tricomas com espiras maiores e irregulares (KOMÁRKOVÁLEGNEROVÁ \& ELORANTA, 1992; ZAPOMELOVÁ et al. 2008).

$\mathrm{Na}$ área estudada, $D$. spiroides foi registrada apenas no plâncton.

Material examinado: HAS 104348, HAS 104351, HAS 104352, HAS 104356, HAS 104381, HAS 104396, HAS 104450. 
Tabela 19: Principais características comparativas entre as espécies de Dolichospermum com tricomas espiralados, documentadas no presente trabalho.

\begin{tabular}{|c|c|c|c|}
\hline & D. crassum & D. flos-aquae & D. spiroides \\
\hline Tricomas & regularmente & irregularmete & regularmente ou \\
\hline & espiralados & espiralados & irregularmente espiralados \\
\hline Envelope mucilaginoso & presente & ausente & presente \\
\hline \multicolumn{4}{|l|}{ Espiras } \\
\hline Diâmetro $(\mu \mathrm{m})$ & $49,0-57,0$ & - & $35,0-47,0$ \\
\hline Distância & $20,0-35,0$ & - & $28,0-34,5$ \\
\hline \multicolumn{4}{|l|}{ Células } \\
\hline Forma & $\begin{array}{l}\text { esféricas ou em forma } \\
\text { de barril }\end{array}$ & $\begin{array}{l}\text { esféricas ou em forma } \\
\text { de barril }\end{array}$ & esféricas \\
\hline Diâmetro & $10,0-12,5$ & $3,8-5,0$ & $7,5-10,0$ \\
\hline Comprimento & $8,0-12,0$ & $5,0-7,0$ & $7,0-10,0$ \\
\hline \multicolumn{4}{|l|}{ Heterócitos } \\
\hline Forma & $\begin{array}{l}\text { esféricos ou achatados } \\
\text { nos pólos }\end{array}$ & esféricos & $\begin{array}{l}\text { esféricos ou achatados } \\
\text { nos pólos }\end{array}$ \\
\hline Diâmetro & $8,0-11,0$ & $4,0-6,0$ & $8,0-14,0$ \\
\hline Comprimento & $7,0-10,5$ & $4,0-6,0$ & $8,0-11,5$ \\
\hline \multicolumn{4}{|l|}{ Acinetos } \\
\hline Forma & elípticos & $\begin{array}{l}\text { ovais a elípticos, } \\
\text { levemente curvos }\end{array}$ & não observados \\
\hline Diâmetro & $12,5-15,0$ & $6,0-11,5$ & \\
\hline Comprimento & $18,0-23,5$ & $15,0-19,8$ & \\
\hline Posição & $\begin{array}{l}\text { distantes dos } \\
\text { heterócitos }\end{array}$ & $\begin{array}{l}\text { distantes dos } \\
\text { heterócitos }\end{array}$ & \\
\hline Hábitat & plâncton & plâncton & plâncton \\
\hline
\end{tabular}

\section{ESPÉCIES COM TRICOMAS RETOS}

Dolichospermum planctonicum (Brunnthaler) Wacklin, Hoffmann et Komárek, Fottea, v. 9, n. 1, p. 62.2009.

Basônimo: Anabaena planctonica Brunnthaler, Sitzungsb. K. Akad. Wiss. Wien, v. 103, n. 1, p. 4.1903.

(Fig. 28A)

Tricomas solitários, retos ou curvos, não atenuados, com envelope mucilaginoso; células em forma de barril ou esféricas, 10,0-14,0 $\mu \mathrm{m}$ diâm., 8,0-11,0 $\mu \mathrm{m}$ compr.; células apicais esféricas; conteúdo celular verde-azulado; heterócitos esféricos, 11,5-13,5 $\mu \mathrm{m}$ diâm.; acinetos elípticos, solitários, distantes dos heterócitos, 13,0-16,5 $\mu \mathrm{m}$ diâm., 17,0-25,0 $\mu \mathrm{m}$ compr.

A população observada exibiu tricomas com acinetos elipsoides, nunca cilíndricos nem atenuados no centro.

D. planctonicum pode ser confundida com D. danicum (Nygaard) Wacklin et al. e com D. viguieri (Denis et Frémy) Wacklin et al. por apresentar tricomas retos, com acinetos 
formados distantes dos heterócitos. No entanto, D. danicum desenvolve tricomas com células alongadas e diâmetros menores $(5,0-7,0 \mu \mathrm{m})$ e D. viguieri apresenta células em forma de barril e diâmetros celulares que variam entre 5,5-7,5 $\mu \mathrm{m}$.

Assim, os espécimes analisados apresentaram características morfométricas que estão de acordo com as citadas para D. planctonicum na literatura consultada (KOMÁREKOVÁLEGNEROVÁ \& ELORANTA, 1992; KOMÁREK \& ZAPOMELOVÁ, 2008).

Material examinado: HAS 104203.

Dolichospermum cf. solitarium (Klebahn) Wacklin, Hoffmann et Komárek, Fottea, v. 9, n. 1, p. 62.2009.

(Fig. 28B)

Basônimo: Anabaena catenula (Kützing) Bornet et Flahault var. solitaria (Klebahn) Geitler, In: Rabenhorst, v. 14, p. 894. 1932; A. solitaria f. solitaria Komárek, Algolog. Stud., p. 137. 1958.

Tricomas solitários, retos ou curvos, não atenuados, com envelope mucilaginoso; células esféricas, 7,5-9,0 $\mu \mathrm{m}$ diâm., 7,8-9,0 $\mu \mathrm{m}$ compr.; células apicais esféricas; conteúdo celular verde-acastanhado, granuloso; heterócitos esféricos, 7,4-8,3 $\mu \mathrm{m}$ diâm.; acinetos não observados.

Originalmente, D. solitarium foi descrita no gênero Anabaena e é caraterizada por apresentar células esféricas e acinetos solitários, cilíndricos com extremidades arredondadas, distantes ou adjacentes aos heterócitos.

Geitler (1932) classificou D. solitarium como uma variedade de Anabaena catenula (Kützing) Bornet et FLahault. Posteriormente, Komárek (1958) inclui três formas em A.solitaria, distinguindo-as pela dimensão e forma dos acinetos (f. planctonica, f. smithii e f. solitaria).

As características exibidas pelos espécimes estudados estão de acordo com as referidas para D. solitarium (KOMÁRKOVÁ-LEGNEROVÁ \& ELORANTA, 1992; KOMÁREK \& ZAPOMELOVÁ, 2008), no entanto, foram identificados como D. cf. solitarium por não terem sido observados acinetos.

Material examinado: HAS 104134, HAS 104350. 
Dolichospermum viguieri (Denis et Frémy) Wacklin, Hoffmann et Komárek, Fottea, v. 9, n. 1, p. 62.2009.

Basônimo: Anabaena viguieri Denis et Frémy, Bull. Soc. Bot. limn. Normandie, Sér. 7, v. 6, p.122. 1924 .

(Figs. 28C, 33C)

Tricomas solitários, retos ou curvos, não atenuados, sem envelope mucilaginoso; células em forma de barril ou esféricas, 5,0-6,5 $\mu \mathrm{m}$ diâm., 4,0-6,5 $\mu \mathrm{m}$ compr.; células apicais esféricas; conteúdo celular verde-azulado, granuloso; heterócitos esféricos, 6,8-7,5 $\mu \mathrm{m}$ diâm.; acinetos elípticos, solitários, distantes dos heterócitos, 9,0-12,5 $\mu \mathrm{m}$ diâm., 16,5-22,0 $\mu \mathrm{m}$ compr.

Os caracteres morfológicos e métricos dos espécimes analisados estão de acordo com os originalmente descritos para D. viguieri (DENIS \& FRÉMY, 1923), exceto pelas dimensões registradas para os acinetos, que se mostraram sensivelmente maiores que os referidos pelos autores. Entretanto, as variações métricas obtidas nas populações estudadas concordam com os mencionados por Franceschini (1992) para populações encontradas nos lagos Açorianos e Guaíba, Porto Alegre, Rio Grande do Sul, identificados como D. affinis Lemmermann f. viguieri (Denis et Frémy) Wacklin et al.

Komárek (1958) classificou D. viguieri como uma forma de D. affinis por considerar que as características que distinguem esses dois táxons são fases de transição de uma única espécie, distinguindo-as em nível de forma. Enquanto D. viguieri desenvolve tricomas solitários, D. affinis apresenta tanto tricomas solitários como em fascículos.

Adicionalmente, Watanabe (1992), a partir de estudos com populações japonesas, considerou os dois táxons como espécies distintas, baseado na forma dos acinetos e na atenuação dos tricomas em $D$. affinis.

D. viguieri também difere de $D$. affinis, por não apresentar envelope mucilaginoso em torno dos tricomas.

Material examinado: HAS 104209, HAS 104213, HAS 104218, HAS 104436. 
Tabela 20: Principais características comparativas entre as espécies de Dolichospermum com tricomas restos, documentadas no presente trabalho.

\begin{tabular}{llll}
\hline & D.planctonicum & D. cf. solitarium & D. viguieri \\
\hline Tricomas & $\begin{array}{l}\text { solitários, não } \\
\text { atenuados } \\
\text { presente }\end{array}$ & $\begin{array}{l}\text { solitários, } \\
\text { não atenuados } \\
\text { presente }\end{array}$ & $\begin{array}{l}\text { solitários, } \\
\text { não atenuados } \\
\text { ausente }\end{array}$ \\
$\begin{array}{l}\text { Células } \\
\text { Forma }\end{array}$ & $\begin{array}{l}\text { esféricas ou em forma } \\
\text { de barril }\end{array}$ & esféricas & $\begin{array}{l}\text { esféricas ou em forma } \\
\text { de barril }\end{array}$ \\
$\begin{array}{l}\text { Diâmetro } \\
\text { Comprimento }\end{array}$ & $10,0-14,0$ & $7,5-9,0$ & $5,0-6,5$ \\
Células apicais & $8,0-11,0$ & $7,8-9,0$ & $4,0-6,5$ \\
Forma & & & \\
Heterócitos & esféricas & esféricas & esféricas \\
Forma & & & \\
Diâmetro & esféricos & esféricos & esféricos \\
Comprimento & $11,5-13,5$ & $7,4-8,3$ & $6,8-7,5$ \\
Acinetos & $11,5-13,5$ & $7,4-8,3$ & $6,8-7,5$ \\
Forma & & não observados & elípticos \\
Diâmetro & elípticos & & $9,0-12,5$ \\
Comprimento & $13,0-16,5$ & & $16,5-22,0$ \\
Posição & $17,0-25,0$ & & distantes dos \\
& distantes dos & & heterócitos \\
Hábitâncton
\end{tabular}

\section{Hydrocoryne Schwabe ex Bornet et Flahault, 1888.}

Espécie tipo: Hydrocoryne spongiosa Schwabe ex Bornet et Flahault, Ann. Sci. nat., Sér. 7, Bot. 5, p. 128. 1888.

Hydrocoryne caracteriza-se por desenvolver talos mucilaginosos micro ou macroscópicos; filamentos com um ou mais tricomas dispostos paralelamente; bainha mucilaginosa firme, incolor, homogênea, até $30 \mu \mathrm{m}$. diâm.; tricomas constritos; células em forma de barril ou mais longas que largas; conteúdo celular homogêneo ou granuloso; células apicais iguais às demais células vegetativas; heterócitos intercalares, em forma de barril a cilíndricos; acinetos solitários, alongados, elípticos ou cilíndricos; reprodução provavelmente por hormogônios.

Hydrocoryne apresenta, obrigatoriamente, mais de um tricoma por bainha. Os acinetos de desenvolvem solitários, no entanto, o gênero é pouco conhecido e suas características taxonômicas precisam ser revisadas. Os filamentos podem apresentar ramificações falsas, entretanto, isso ocorre somente na bainha mucilaginosa. Tais ramificações, sem a fragmentação dos tricomas, também ocorrem em Scytonemataceae e Microchaetaceae.

O gênero é composto por apenas duas espécies, $H$. spongiosa e $H$. neocaledonica Couté, Tell et Thérézién, que crescem em ambientes pantanosos de água doce e em ambientes aerofíticos, respectivamente (GEITLER, 1932; COUTÉ et al., 1999). 
O gênero Hormothamnion é semelhante a Hydrocoryne, sendo que a única diferença entre os gêneros é o tipo de formação dos acinetos: apoheterocíticos em Hormothamnion.

No presente estudo foi registrada a ocorrência de apenas uma espécie não identificada do gênero.

\section{Hydrocoryne sp.}

(Figs. 28D, 34B-C)

Filamentos solitários, flexuosos, ramificados ou não, 12,0-22,0 $\mu \mathrm{m}$ diâm.; bainha mucilaginosa homogênea, firme, incolor, levemente estriada; tricomas organizados paralelamente, 1-4 tricomas por bainha, constritos, 4,8-5,5 $\mu \mathrm{m}$ diâm.; células em forma de barril ou subesféricas, 3,0-4,5 $\mu \mathrm{m}$ compr.; célula apical esférica; conteúdo celular verdeazulado, homogêneo; sem aerótopos; heterócitos intercalares, esféricos ou quadráticos, 6,88,0 $\mu \mathrm{m}$ diâm., 7,5-9,0 $\mu \mathrm{m}$ compr.; acinetos cilíndricos, solitários ou aos pares, de ambos os lados do heterócito, 6,0-9,0 $\mu \mathrm{m}$ diâm., 11,0-20,0 $\mu \mathrm{m}$ compr.

O gênero possui apenas duas espécies descritas (KOMÁREK \& HAUER, 2009). Os espécimes analisados diferem de $H$. spongiosa por apresentarem tricomas com diâmetros maiores que os referidos para a espécie (3,0-4,0 $\mu \mathrm{m}$ diâm.). As dimensões dos heterócitos de $H$. spongiosa também são menores que os observados no presente estudo (4,0 $\mu$ m diâm.).

Hydrocoryne sp. difere de $H$. neocaledonica, tanto em relação às características morfológicas e métricas, quanto em relação ao ambiente onde ocorrem. $H$. neocaledonica exibe filamentos maiores $(28,0-30,0 \mu \mathrm{m}$ diâm.), tricomas com diâmetros superiores $(5,5-6,0$ $\mu \mathrm{m})$ e ocorrem em ambientes aerofíticos.

A população observada difere das duas espécies que compõem o gênero Hydrocoryne, tendo sido registrado apenas no plâncton e, provavelmente, trata-se de uma nova espécie para a ciência.

Material examinado: HAS 104134.

Subfamília Nostocoideae (Borzi) Komárek et Anagnostidis, 1989.

\section{CHAVE PARA IDENTIFICAÇÃO DOS GÊNEROS ENCONTRADOS}

1. Filamentos solitários Aulosira

1. Filamentos coloniais Nostoc 


\section{Aulosira Kirchner ex Bornet et Flahault, 1888.}

Espécie-tipo: Aulosira laxa Kirchner ex Bornet et Flahault, Ann. Sci. Nat., Sér. 7, Bot. 7, p. 256. 1888.

O gênero Aulosira é caracterizado por desenvolver filamentos solitários ou em grupos, raramente formando massas; bainha mucilaginosa firme, incolor, homogênea, margem evidente; tricomas constritos, não atenuados, metaméricos; células cilíndricas ou em forma de barril, mais ou menos isodiamétricas a mais longas que largas; conteúdo celular homogêneo ou granuloso; aerótopos facultativos; células apicais arredondadas; heterócitos esféricos, ovais ou cilíndricos; acinetos geralmente alongados, ovais a cilíndricos, raramente esféricos; reprodução por hormogônios ou por acinetos.

O gênero é composto principalmente por espécies metafíticas, que crescem em ambientes não poluídos. Muitas espécies são importantes componentes da microflora dos solos de plantações de arroz. Quase todas as espécies ocorrem em áreas geograficamente limitadas, principalmente em regiões tropicais (KOMÁREK \& HAUER, 2009).

A estrutura do filamento de Aulosira é semelhante à de Nodularia, pois ambos apresentam tricomas envolvidos por uma bainha firme, com margem evidente e extremidades abertas. No entanto, esses gêneros podem ser distinguidos pela forma das células que são, obrigatória e claramente, mais curtas que largas a discoides em Nodularia, enquanto Aulosira apresenta tricomas com células em forma de barril, mais ou menos isodiamétricas ou mais longas que largas (KOMÁREK \& ANAGNOSTIDIS, 1989). A formação dos acinetos nos dois gêneros é semelhante: apoheterocítico, próximos aos heterócitos ou distantes deles, às vezes em fileiras.

Originalmente, Aulosira foi classificado como próximo ao gênero Microchaete, pois, segundo Geitler (1942), os filamentos de ambos os gêneros são similares nas porções centrais. No entanto, o desenvolvimento dos filamentos nestes gêneros é diferente: os acinetos se desenvolvem apoheterociticamente e os filamentos são sempre isopolares em Aulosira, enquanto que em Microchaete, os filamentos são sempre polarizados.

No presente estudo foi identificada apenas uma espécie de Aulosira, A. laxa.

Aulosira laxa Kirchner, ex Bornet et Flahault, Ann. Sci. Nat., Sér. 7, Bot. 7, p. 256. 1888.

(Figs. 28E, 34A)

Filamentos retos ou curvos, 5,4-7,5 $\mu \mathrm{m}$ diâm.; bainha mucilaginosa incolor, firme, homogênea; tricomas constritos; células em forma de barril, 4,5-6,0 $\mu \mathrm{m}$ diâm., 3,0-4,5 $\mu \mathrm{m}$ 
compr.; conteúdo celular verde azulado, homogêneo; heterócitos intercalares, esféricos a

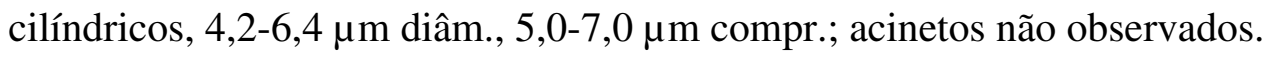

Os espécimes analisados estão de acordo com a literatura consultada (BORNET \& FLAHAULT, 1886-1888; GEITLER, 1932).

A população observada apresentou valores de diâmetro celular que ampliam o intervalo referido por Bornet \& Flahault (1886-1888), no entanto, estão de acordo com as populações observadas para o estado de São Paulo por Sant’Anna \& Azevedo (1995).

No presente estudo, Aulosira laxa foi observada tanto no plâncton como no metafíton.

Material examinado: HAS 104092, HAS 104105, HAS 104112, HAS 104117, HAS 104125, HAS 104127, HAS 104147, HAS 104180, HAS 104381.

\section{Nostoc Vaucher ex Bornet et Flahault, 1886-1888.}

Espécie-tipo: Nostoc commune Vaucher ex Bornet et Flahault, Ann. Sci. nat., Sér. 7, Bot.7, p. 203. 1886-1888.

O gênero Nostoc caracteriza-se por desenvolver talos micro ou macroscópicos, gelatinosos, membranosos ou coriáceos, amorfos ou esféricos, superfície lisa ou rugosa; colônias filamentosas, achatadas; filamentos irregularmente enrolados, esparsa ou densamente aglomerados na mucilagem colonial; tricomas envoltos por mucilagem e bainha mucilaginosa ampla, fina, mucilaginosa, incolor, amarela ou acastanhada; tricomas não atenuados, fortemente constritos; células cilíndricas, em forma de barril ou esféricas; heterócitos solitários, intercalares e terminais, esféricos, ovais, elípticos; acinetos ovais, maiores que as células vegetativas; reprodução através de hormogônios, fragmentação das colônias ou pela produção de acinetos.

Nostoc exibe um ciclo de vida especial, durante o qual cada estágio apresenta suas próprias características morfológicas (KOMÁREK \& ANAGNOSTIDIS, 1989).

Ocorrem em ambientes terrestres ou aquáticos de água doce. Apresentam ampla distribuição geográfica e algumas espécies são importantes componentes de solos subpolares. Poucas espécies crescem endofiticamente em fungos, briófitas e plantas vasculares.

Além de Nostoc, o gênero Wollea Bornet et Flahault também se caracteriza por desenvolver colônias gelatinosas macroscópicas. As colônias de Wollea são alongadas e cilíndricas (BORNET \& FLAHAULT, 1886), enquanto, em Nostoc, elas são variáveis. Os gêneros também diferem quanto à disposição dos tricomas na colônia que, em Wollea, são dispostos mais ou menos paralelamente, e ao tipo de formação dos acinetos, paraheterocíticos em Wollea. 
Elenkin (1935) dividiu Nostoc em quatro gêneros baseado na morfologia da colônia (Amorphonostoc Elenkin, Sphaeronostoc Elenkin, Stratonostoc e Nematonostoc Elekin). No entanto, essa classificação não foi muito aceita (DESIKACHARY, 1959; STARMACH, 1966; BOURRELLY, 1985) devido ao fato de muitas espécies desenvolverem colônias morfologicamente variadas, de acordo com a fase do ciclo de vida.

No presente estudo foram identificadas duas espécies, Nostoc spongiaeforme e $N$. cf. piscinale.

\section{Chave de identificação das espécies encontradas}

1. Tricomas com células esféricas ou em forma de barril N. cf. piscinale

1. Tricomas com células ovais ou cilíndricas N. spongiaeforme

Nostoc cf. piscinale Kützing, Phyc. gen., 208. 1843.

(Figs. 29A, 34E)

Colônias esféricas a alongadas, 56,0-140,0 $\mu \mathrm{m}$ diâm., 79,0-220,0 $\mu \mathrm{m}$ compr.; mucilagem incolor, firme, homogênea; tricomas flexuosos, frouxamente emaranhados; células em forma de barril a esféricas, 4,0-5,5 $\mu \mathrm{m}$ diâm.; 4,0-5,5 $\mu \mathrm{m}$ compr.; conteúdo verde-azulado, homogêneo ou finamente granuloso; heterócitos terminais esféricos ou ovais, intercalares esféricos, 5,5-7,0 $\mu \mathrm{m}$ diâm., 5,5-7,5 $\mu \mathrm{m}$ compr.; acinetos não observados.

As características morfológicas e métricas dos espécimes analisados estão de acordo com a população de $N$. piscinale descrita por (BORNET \& FLAHAULT, 1886-1888). Embora os espécimes apresentem características que correspondem a Nostoc piscinale, os mesmos foram identificados como $N$. cf. piscinale por não terem sido observados acinetos, importantes na identificação das espécies do gênero.

Embora Nostoc seja principalmente perifítico e também comum em ambientes terrestres úmidos, no presente trabalho, Nostoc cf. piscinale foi observado no plâncton e no metafíton de lagoas rasas e com muita vegetação, fato que pode explicar sua ocorrência em tais locais.

Material examinado: HAS 104117, HAS 104125, HAS 104131, HAS 104147, HAS 104174.

Nostoc spongiaeforme Agardh, Syst. Alg., 22. 1824.

(Figs. 29B, 34D)

Colônias esféricas a alongadas, 25,0-65,0 $\mu \mathrm{m}$ diâm., 30,0-97,0 $\mu \mathrm{m}$ compr.; mucilagem incolor, firme, homogênea; tricomas flexuosos, frouxamente emaranhados; células ovais a 
cilíndricas com extremidades arredondadas, 4,0-5,0 $\mu \mathrm{m}$ diâm.; 5,0-7,0 $\mu \mathrm{m}$ compr.; conteúdo verde-azulado, homogêneo; heterócitos terminais esféricos ou ovais, intercalares esféricos, ovais ou elípticos, 5,5-6,0 $\mu \mathrm{m}$ diâm., 5,5-8,0 $\mu \mathrm{m}$ compr.; acinetos esféricos a elípticos, em série, distantes dos heterócitos, 6,0-8,5 $\mu \mathrm{m}$ diâm., 7,0-11,0 $\mu \mathrm{m}$ compr., episporo liso, incolor.

Nostoc spongiaeforme caracteriza-se por apresentar tricomas com células alongadas. Outra espécie que desenvolve tricomas com células mais longas que largas é N. carneum, no entanto, esta difere de $N$. spongiaeforme por apresentar células com diâmetro menor (3,0-4,0 $\mu \mathrm{m})$ e arredondadas ou em forma de barril.

A população analisada apresentou características morfológicas e métricas que estão de acordo com as descritas para N. spongiaeforme (GEITLER, 1932).

Material examinado: HAS 104174.

\section{MASTIGOCLADACEAE Geitler, 1925.}

Mastigocladaceae caracteriza-se por desenvolver filamentos unisseriados, sem distinção entre ramo principal e secundários; ramificações do tipo "T", "V" e "Y"; heterócitos intercalares ou ausentes; reprodução através de hormogônios, hormocitos ou acinetos, excepcionalmente, através de nanócitos.

A família é composta por 14 gêneros divididos em duas subfamílias, baseadas na morfologia da porção apical dos tricomas. Mastigocladoideae, que abrange nove gêneros, apresenta tricomas com ápices mais ou menos cilíndricos, com células arredondadas, enquanto Brachytrichioideae, composta por cinco gêneros, desenvolve tricomas com extremidades atenuadas, às vezes formando pelos (ANAGNOSTIDIS \& KOMÁREK, 1990).

Segundo a classificação proposta por Anagnostidis \& Komárek (1990), a divisão das cianobactérias heterocitadas com ramificações verdadeiras em famílias, baseia-se em características morfológicas tais como: estrutura dos filamentos, definida principalmente pelo tipo de divisão celular em diferentes planos; tipos de ramificações; presença ou ausência dos heterócitos, bem como sua disposição nos filamentos.

Com base nas características citadas acima, apenas três famílias são bem delimitadas (Chlorogloeopsaceae, Borzinemataceae e Nostochopsaceae). Entre as demais famílias de Stigonematales, inclusive Mastigocladaceae, existem morfotipos intermediários, dificultando a delimitação (ANAGNOSTIDIS \& KOMÁREK, 1990). 
Segundo Hoffmann et al. (2005), os gêneros que compõem Mastigocladaceae foram classificados nas famílias Hapalosiphonaceae (5) e Symphyonemataceae (9).

No presente estudo, foram identificadas três espécies pertencentes a apenas um gênero de Mastigocladaceae: Hapalosiphon.

\section{Hapalosiphon Nägeli ex Bornet et Flahault, 1886.}

Espécie-tipo: Hapalosiphon pumilus Kirchner ex Bornet et Flahault, Ann. Sci. Nat. Bot. Sér. 7 , v. 5 , p. 54.1886.

O gênero Hapalosiphon caracteriza-se por apresentar talos mucilaginosos livres ou presos no substrato; filamentos irregularmente curvos, unisseriados; ramificações preferencialmente unilaterais (“T”) e semelhantes ao filamento principal, raramente mais estreitas; bainha mucilaginosa fina, firme, incolor, homogênea, raramente lamelada; células cilíndricas ou em forma de barril; conteúdo celular homogêneo ou granuloso; heterócitos intercalares, excepcionalmente laterais, cilíndricos ou em forma de barril; acinetos raros e solitários; reprodução através de hormogônios.

Muitas espécies vivem em águas paradas, podendo ocorrer livres, emaranhadas em outras cianobactérias ou algas, ou como epífitas, tanto em regiões tropicais como temperadas.

Hapalosiphon e Fischerella (Bornet et Flahault) Gomont são gêneros próximos. Segundo Frémy (1930) e Geitler (1932), a distinção entre esses dois gêneros é baseada no hábitat, tipo de talo, estrutura do filamento e posição dos heterócitos. Outro gênero morfologicamente semelhante ao Hapalosiphon é Westiella Borzi. A principal característica que distingue os dois gêneros é a presença de hormocistos em Westiella.

No presente estudo foram identificadas três espécies pertencentes ao gênero em questão: Hapalosiphon arboreus, H. stuhlmannii e Hapalosiphon sp.

\section{Chave para identificação das espécies encontradas}

1. Organismos epífitos

Hapalosiphon $\mathrm{sp}$.

1. Organismos não epífitos

2. Ramo principal e ramos secundários iguais H. arboreus

2. Ramo principal e ramos secundários distintos H. hibernicus 
Hapalosiphon arboreus West et G. S. West, J. Linn. Soc. Bot., v. 30, p. 272. 1894.

(Figs.30A-B, 35E-F)

Filamentos isolados; filamento principal reto ou curvo, 6,5-9,5 (12,5) $\mu \mathrm{m}$ diâm.; bainha mucilaginosa homogênea, incolor, firme, estreita; tricomas constritos, unisseriados; células subesféricas, quadráticas ou cilíndricas, 4,0-8,0 $\mu \mathrm{m}$ diâm., 4,0-9,0 $\mu \mathrm{m}$ compr.; conteúdo celular verde-azulado, homogêneo ou granuloso; filamentos secundários simples ou geminados, usualmente perpendiculares ao filamento principal, retos ou curvos, curtos, até 137,0 $\mu \mathrm{m}$ compr., 5,0-7,5 $\mu \mathrm{m}$ diâm.; células quadráticas a cilíndricas, 3,5-5,5 $\mu \mathrm{m}$ diâm., 4,012,0 $\mu \mathrm{m}$ compr.; heterócitos intercalares, subquadráticos a cilíndricos, 4,5-6,5 $\mu \mathrm{m}$ diâm., 5,09,8 $\mu \mathrm{m}$ compr.; hormogônios não observados.

Os espécimes analisados apresentam características morfológicas e métricas de acordo com as citadas para a espécie (FRÉMY, 1930; GEITLER, 1932).

Hapalosiphon welwitschii West et G. S. West é a espécie morfologicamente mais próxima de H. arboreus, com hábito e morfologia semelhantes. Segundo Geitler (1932), as duas espécies diferem pelo diâmetro do filamento principal, que é menor em $H$. welwitschii (5,5-7,5 $\mu \mathrm{m})$, embora haja uma pequena sobreposição.

Embora as populações observadas tenham apresentado filamentos com diâmetros que podem pertencer tanto a $H$. arboreus e $H$. welwitschii, grande parte dos valores concentra-se dentro do intervalo referido para $H$. arboreus, tendo a população sido identificada como tal.

$\mathrm{Na}$ área de estudo, H. arboreus foi observada ocorrendo tanto no plâncton como no metafíton e constitui no primeiro registro da espécie para o Rio Grande do Sul.

Material examinado: HAS 104124, HAS 104134, HAS 104195, HAS 104202, HAS 104207, HAS 104209, HAS 104220, HAS 104416, HAS 104431.

Hapalosiphon hibernicus West et G. S. West, Die Pflanzenwelt Ost-Afrikas, 10. 1894.

(Fig. 31A-B)

Filamentos emaranhados ou isolados; filamento principal curvo ou flexuoso, 6,0-10,0 $\mu \mathrm{m}$ diâm.; bainha mucilaginosa homogênea, incolor, firme, estreita; tricomas constritos, unisseriados ou, raramente, 2 séries de células; células subquadráticas a cilíndricas, raramente subesféricas, 4,0-5,5 $\mu \mathrm{m}$ diâm., 4,0-10,0 $\mu \mathrm{m}$ compr.; conteúdo celular verde-azulado, homogêneo ou granuloso; filamentos secundários simples ou geminados, usualmente perpendiculares ao filamento principal, curvos ou flexuosos, longos, até $2 \mathrm{~mm}$ compr., 5,5-8,5 $\mu \mathrm{m}$ diâm.; células quadráticas a cilíndricas, 2,0-4,0 $\mu \mathrm{m}$ diâm., 7,0-30,0 $\mu \mathrm{m}$ compr.; 
heterócitos intercalares, cilíndricos, 4,5-5,5 $\mu \mathrm{m}$ diâm., 10,0-15,0 $\mu \mathrm{m}$ compr.; hormogônios não observados.

Com base em obras clássicas como Frémy (1930) e Geitler (1932), os espécimes observados podem ser identificados tanto como $H$. stuhlmannii Hieronymus como $H$. hibernicus. Segundo esses autores, as características que diferem as espécies de Hapalosiphon é, principalmente, o diâmetro do filamento principal. No entanto, esta característica não é suficiente para diferenciar as duas espécies, pois ambas apresentam valores que se sobrepõem.

A identificação das populações observadas como $H$. hibernicus baseou-se principalmente no diâmetro celular, pois, segundo Geitler (1932), H. stuhlmannii apresenta células com diâmetros maiores que as registradas nas populações observadas (5,0-8,0 $\mu \mathrm{m})$.

H. hibernicus difere das populações identificadas como H. arboreus, principalmente por apresentarem filamentos secundários morfologicamente distintos dos filamentos principais, enquanto em $H$. arboreus, não é observada uma diferenciação acentuada. Em $H$. hibernicus, as células dos filamentos secundários são mais estreitas e longas.

No presente estudo, H. hibernicus foi observada tanto no plâncton quanto no metafíton, e constitui a primeira citação da espécie para o estado do Rio Grande do Sul.

Material examinado: HAS 104202, HAS 104230, HAS 104232, HAS 104234, HAS 104435.

\section{Hapalosiphon sp.}

(Figs. 31C, 35A-D)

Filamentos isolados, epifíticos, raramente livres; filamento principal reto ou curvo, prostrado, 5,5-7,5 $\mu \mathrm{m}$ diâm.; bainha mucilaginosa homogênea, incolor, firme, estreita ou inconspícua; tricomas constritos, unisseriados; células subesféricas, subquadráticas ou irregulares, 4,0-7,0 $\mu \mathrm{m}$ diâm., 4,0-7,0 $\mu \mathrm{m}$ compr.; conteúdo celular verde-azulado, homogêneo ou granuloso; filamentos secundários simples ou geminados, usualmente perpendiculares ao filamento principal, retos ou curvos, prostrados ou não, 5,0-6,2 $\mu \mathrm{m}$ diâm.; células subquadráticas a cilíndricas, subesféricas ou irregulares, 4,0-6,0 $\mu \mathrm{m}$ diâm., 4,0-7,0 $\mu \mathrm{m}$ compr.; heterócitos intercalares, subquadráticos, subesféricos ou ovais, 5,0-6,5 $\mu \mathrm{m}$ diâm., 7,08,5 $\mu$ m compr.; hormogônios não observados.

A população identificada como Hapalosiphon sp. é morfologicamente muito semelhante a $H$. arboreus, no entanto, apresenta filamento levemente mais estreito e bainha mucilaginosa delicada, às vezes inconspícua. 
Os espécimes assemelham-se a $H$. welwitschii, apresentando características morfológicas e métricas que correspondem às referidas para a espécie por Geitler (1932). Entretanto, a população não foi identificada como $H$. welwitschii por exibir hábito diferente.

Os espécimes identificados como Hapalosiphon sp. são organismos epífitos, sendo raramente encontrados livres. Os filamentos observados foram encontrados aderidos em vegetais aquáticos.

Nas áreas estudadas, Hapalosiphon sp. foi registrada tanto no plâncton como no metafíton e possivelmente trata-se de uma espécie nova para a ciência.

Material examinado: HAS 104213, HAS 104227, HAS 104445.

Tabela 21: Principais características comparativas entre as espécies de Hapalosiphon documentadas no presente trabalho.

\begin{tabular}{|c|c|c|c|}
\hline & H. arboreus & H. hibernicus & Hapalosiphon sp. \\
\hline Filamentos & isolados & $\begin{array}{l}\text { emaranhados ou } \\
\text { isolados }\end{array}$ & epifíticos \\
\hline \multicolumn{4}{|l|}{ Filamentos principais } \\
\hline Diâmetro $(\mu \mathrm{m})$ & $6,5-9,5(12,5)$ & $6,0-10,0$ & $5,5-7,5$ \\
\hline Células & $\begin{array}{l}\text { quadráticas ou } \\
\text { cilíndricas }\end{array}$ & $\begin{array}{l}\text { subquadráticas a } \\
\text { cilíndricas, raramente } \\
\text { subesféricas }\end{array}$ & $\begin{array}{l}\text { subesféricas, } \\
\text { subquadráticas ou } \\
\text { irregulares }\end{array}$ \\
\hline \multicolumn{4}{|l|}{ Tricomas } \\
\hline Diâmetro $(\mu \mathrm{m})$ & $4,0-8,0$ & $4,0-5,5$ & $4,0-7,0$ \\
\hline Comprimento $(\mu \mathrm{m})$ & $4,0-9,0$ & $4,0-10,0$ & $4,0-7,0$ \\
\hline \multicolumn{4}{|c|}{ Filamentos secundários } \\
\hline Diâmetro $(\mu \mathrm{m})$ & $5,0-7,5$ & $5,5-8,5$ & $5,0-6,2$ \\
\hline Células & $\begin{array}{l}\text { quadráticas a } \\
\text { cilíndricas }\end{array}$ & $\begin{array}{l}\text { células quadráticas a } \\
\text { cilíndricas }\end{array}$ & $\begin{array}{l}\text { subesféricas, } \\
\text { subquadráticas ou } \\
\text { irregulares }\end{array}$ \\
\hline \multicolumn{4}{|l|}{ Tricomas } \\
\hline Diâmetro $(\mu \mathrm{m})$ & $3,5-5,5$ & $2,0-4,0$ & $4,0-6,0$ \\
\hline Comprimento $(\mu \mathrm{m})$ & $4,0-12,0$ & $7,0-30,0$ & $4,0-7,0$ \\
\hline Heterócitos & $\begin{array}{l}\text { intercalares, } \\
\text { subquadráticos a } \\
\text { cilíndricos }\end{array}$ & $\begin{array}{l}\text { intercalares, } \\
\text { cilíndricos }\end{array}$ & $\begin{array}{l}\text { intercalares, } \\
\text { subquadráticos, } \\
\text { subesféricos ou ovais }\end{array}$ \\
\hline Diâmetro $(\mu \mathrm{m})$ & $4,5-6,5$ & $4,5-5,5$ & $5,0-6,5$ \\
\hline Comprimento $(\mu \mathrm{m})$ & $5,0-9,8$ & $10,0-15,0$ & $7,0-8,5$ \\
\hline Conteúdo celular & $\begin{array}{l}\text { verde-azulado, } \\
\text { homogêneo ou } \\
\text { granuloso }\end{array}$ & $\begin{array}{l}\text { verde-azulado, } \\
\text { homogêneo ou } \\
\text { granuloso }\end{array}$ & $\begin{array}{l}\text { verde-azulado, } \\
\text { homogêneo ou } \\
\text { granuloso }\end{array}$ \\
\hline Hábitat & plâncton e metafíton & plâncton e metafíton & epifítico \\
\hline
\end{tabular}




\section{STIGONEMATACEAE Agardh $e x$ Bornet et Flahault, 1886.}

Stigonemataceae caracteriza-se por desenvolver filamentos unisseriados ou multisseriados, com distinção entre ramo principal e ramos secundários; heterócitos intercalares ou ausentes; reprodução através de hormogônios ou hormocistos.

A família é composta por três gêneros _ Homoeoptyche Skuja, Pulvinularia Borzi, Stigonema Agardh ex Bornet et Flahault (ANAGNOSTIDIS \& KOMÁREK, 1990).

Segundo Hoffmann et al. (2005), a família é composta por nove gêneros: Capsosira, Cyanobotrys , Desmosiphon, Doliocatella, Homoeoptyche, Nematoplaca, Pulvinularia, Stauromatinema e Stigonema.

No presente estudo, foi identificada apenas uma espécie pertencente ao gênero Stigonema.

\section{Stigonema Agardh ex Bornet et Flahault, 1886.}

Espécie-tipo: Stigonema mamillosum Agardh ex Bornet et Flahault, Ann. Sci. Nat. Bot. 7, v. 5, p. 62.1886.

O gênero Stigonema caracteriza-se por apresentar talos mucilaginosos, livres ou presos no substrato; filamentos irregularmente curvos, unisseriados ou multisseriados; ramificações em ambos os lados do filamento principal ("T" ou "V"); filamentos secundários distintos dos filamentos principais em estágios iniciais e indistintos em filamentos maduros; bainha mucilaginosa fina ou espessa, incolor, lamelada, amarelada ou amarronzada; tricomas formados por várias séries de células em forma de barril ou irregularmente arredondadas, conectadas por poros; conteúdo celular verde-azulado ou verde oliva, usualmente com um único grânulo proeminente; heterócitos intercalares, solitários, raramente laterais, semelhante às células vegetativas vizinhas; acinetos não conhecidos; reprodução através de hormogônios terminais ou laterais, raramente por conídios e hormocistos. Algumas espécies possuem os filamentos constituídos por grupos de células, envolvidos por bainha comum, apresentando aspecto compacto.

As espécies de Stigonema ocorrem em vários biótopos ao redor do mundo, normalmente aderidas ao substrato ou no solo. Muitas espécies são aerofíticas, sendo encontradas em troncos de árvores, rochas úmidas. Podem ser encontradas em ambientes aquáticos, preferencialmente não poluídos, lênticos ou lóticos, ocorrendo no metafíton ou aderidos em rochas submersas. 
No presente estudo foi identificada apenas uma espécie pertencente ao gênero em questão: S. ocellatum.

Stigonema ocellatum (Dillwyn) Thuret ex Bornet et Flahault, Ann. Sci. nat., Sér. 7, Bot. 5, p. 69. 1886.

Basônimo: Conferva atro-virens Dillwuyn, Brit. Conf. 25. 1803.

(Fig. 36A-F)

Filamentos emaranhados ou isolados; filamento principal prostrado, flexuoso, 18,542,0 $\mu \mathrm{m}$ diâm.; bainha mucilaginosa ampla, firme, homogênea ou lamelada, incolor nas partes jovens, amarela a castanha, ocasionalmente mais escuras ao redor das células; tricomas constritos, unisseriados ou, raramente, 2 séries de células, 7,5-29,0 $\mu \mathrm{m}$ diâm.; células subesféricas, subquadráticas ou oblongas, 6,0-19,0 $\mu \mathrm{m}$ diâm., 5,5-20,0 $\mu \mathrm{m}$ compr.; conteúdo celular verde-azulado a verde-amarelado, homogêneo ou granuloso; filamentos secundários esparsos, eretos, flexuosos, 12,0-27,0 m diâm.; ápices cilíndricos, não dilatados; tricomas unisseriados, raramente com duas séries de células, 3,5-23,5 $\mu$ m diâm.; células com 3,5-17,5 $\mu \mathrm{m}$ diâm., 4,0-20,0 $\mu \mathrm{m}$ compr.; heterócitos intercalares ou laterais, subquadráticos, subesféricos a oblongos, 8,0-16,0 $\mu \mathrm{m}$ diâm., 6,5-13,5 $\mu \mathrm{m}$ compr.; hormogônios abundantes, terminais, constritos, não atenuados, raramente dilatados, 7,5-18,0 $\mu \mathrm{m}$ diâm., até 260,0 $\mu \mathrm{m}$ compr.; hormocistos e conídios não observados.

As características morfológicas e métricas dos espécimes analisados estão de acordo com as referidas para S. ocellatum (FRÉMY, 1930; GEITLER, 1932).

Stigonema ocellatum é morfologicamente semelhante a $S$. paniforme Bornet et Flahault, no entanto, esta última apresenta filamento principal mais estreito $(35-40 \mu \mathrm{m})$, células mais ou menos discoides e hormogônios dilatados (FRÉMY, 1930), enquanto $S$. ocellatum, bem como os espécimes analisados, apresentam filamento principal mais largo, células subesféricas e hormogônios não atenuados, às vezes, levemente dilatados e com bainha mucilaginosa com lamelas levemente divergentes.

Segundo Geitler (1932), S. ocellatum é uma espécie amplamente distribuída, provavelmente cosmopolita, ocorrendo em ambientes aquáticos, aerofíticos e terrestres úmidos. No Brasil, a sua ocorrência já foi documentada em vários trabalhos: Möbius (1895), Bicudo \& Bicudo (1969), Campos (1986), Drouet (1938), Thomasson (1971), Senna (1982), Silva \& Sant'Anna (1996).

No presente estudo, S. ocellatum foi encontrada tanto no plâncton como no metafíton, constituindo no primeiro registro da espécie no Rio Grande do Sul.

Material examinado: HAS 104232, HAS 104234. 


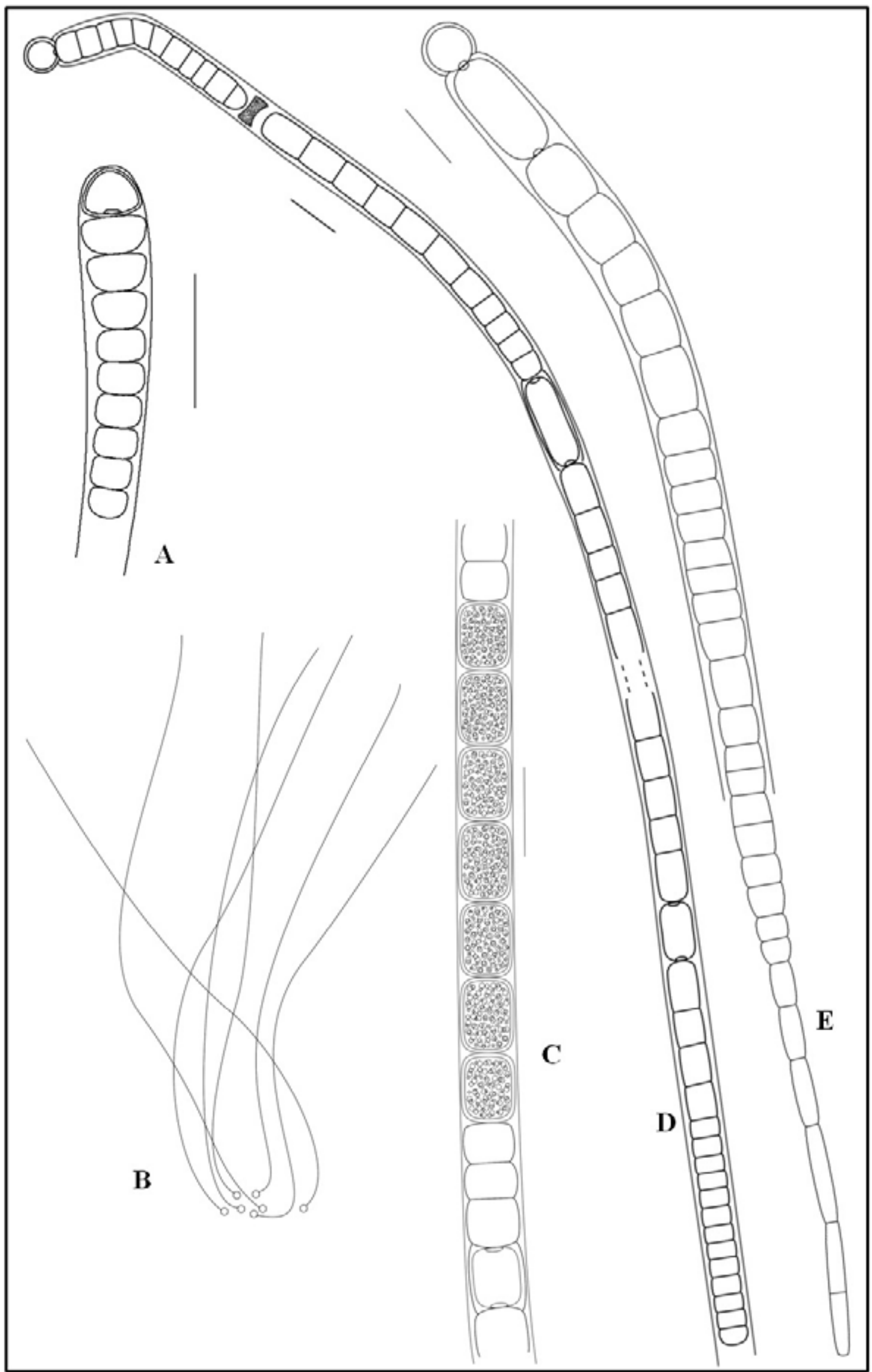

Fig. 23: A-E. A. Calothrix brevissima G. S. West; B-D. Microchaete violacea Frémy. B. disposiçăo dos filamentos; C. acinetos; D. filamento; E. Calothrix scytonemicola Tilden. Escalas: $\mathrm{A}, \mathrm{C}, \mathrm{E}=10 \mu \mathrm{m} ; \mathrm{D}=20 \mu \mathrm{m}$. 


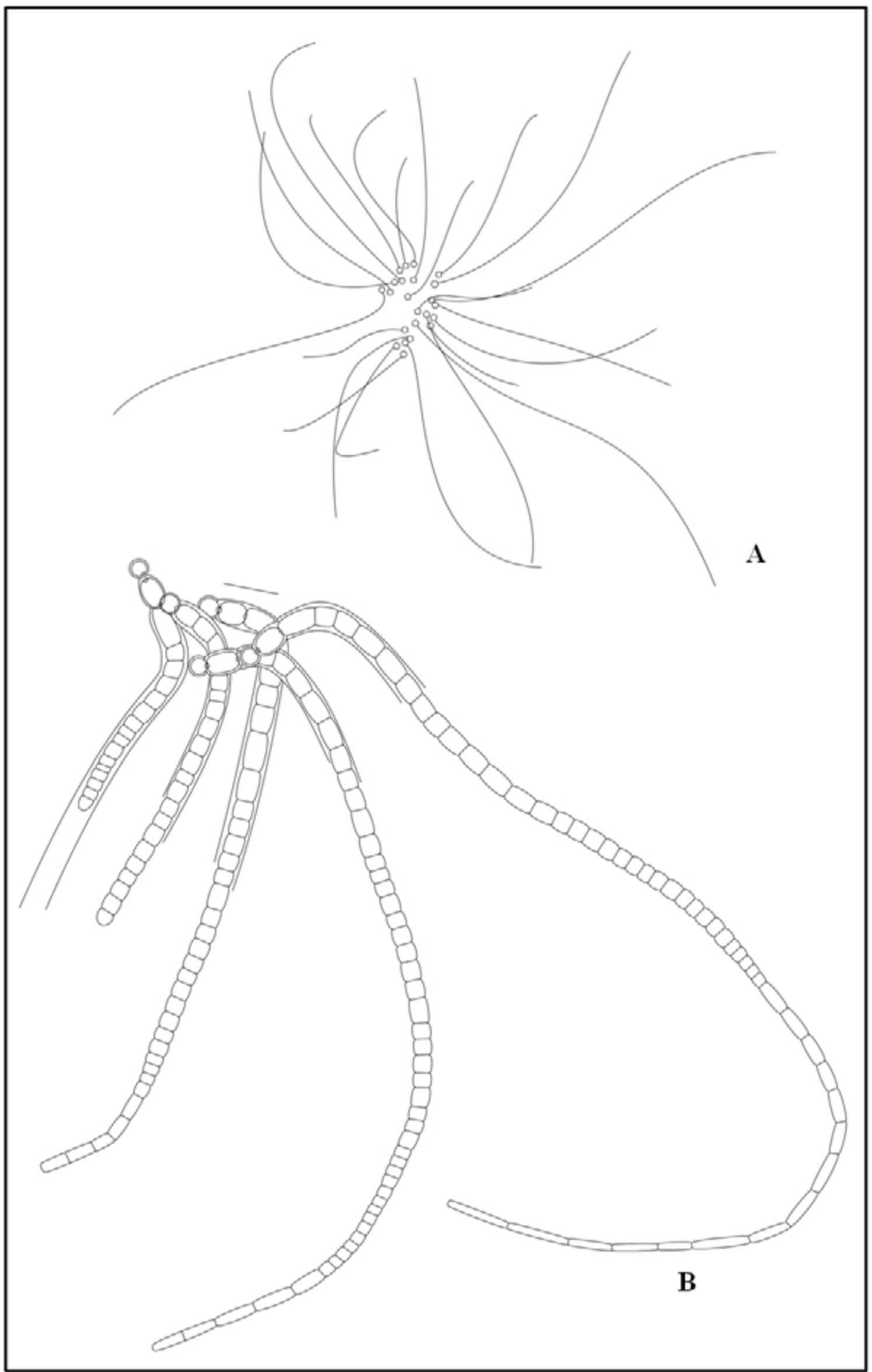

Fig. 24: A-B. Gloeotrichia longicauda Schmidle. A. disposição dos filamentos; B. detallhe dos filamentos. Escala: $20 \mu \mathrm{m}$. 

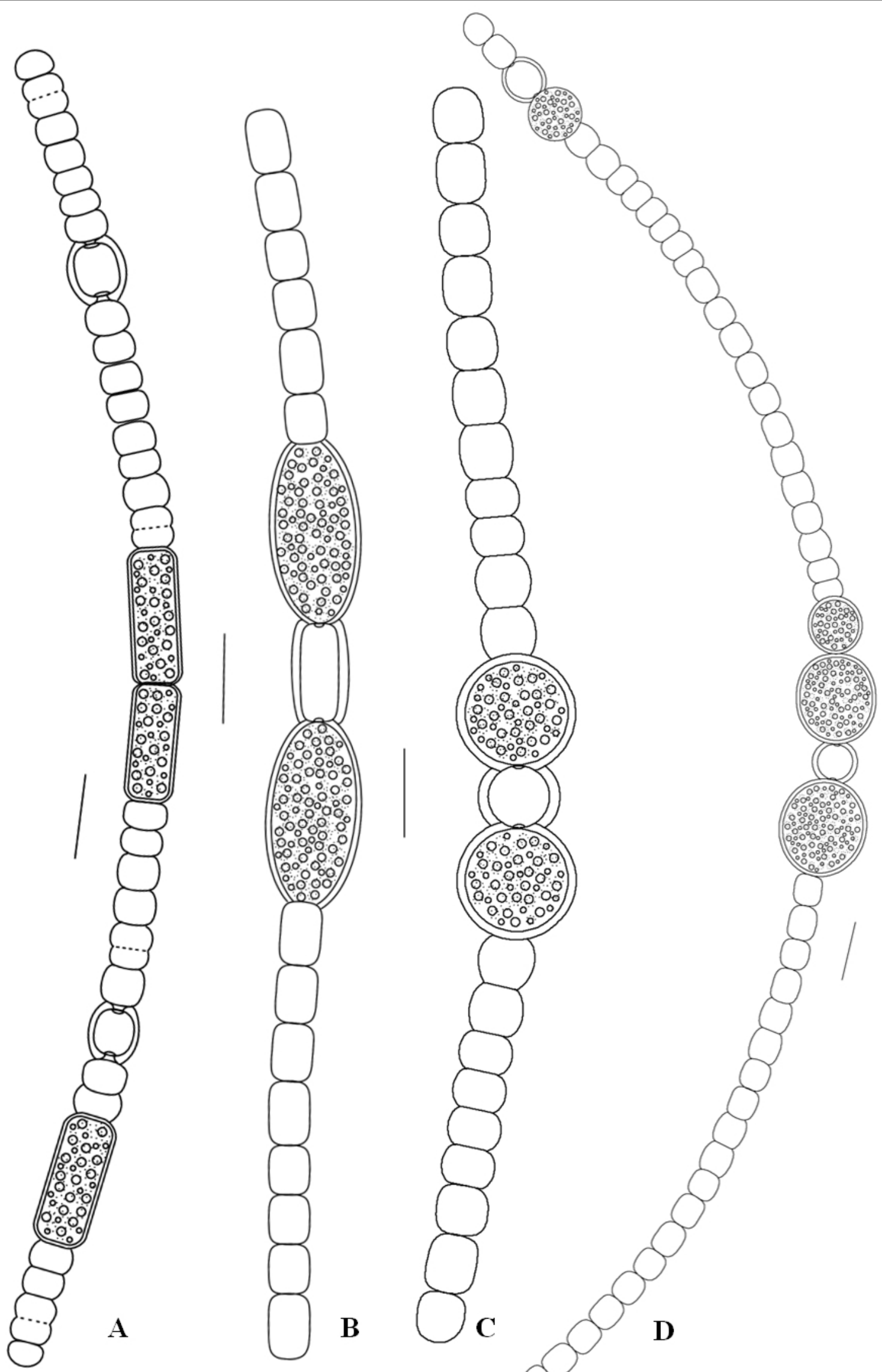


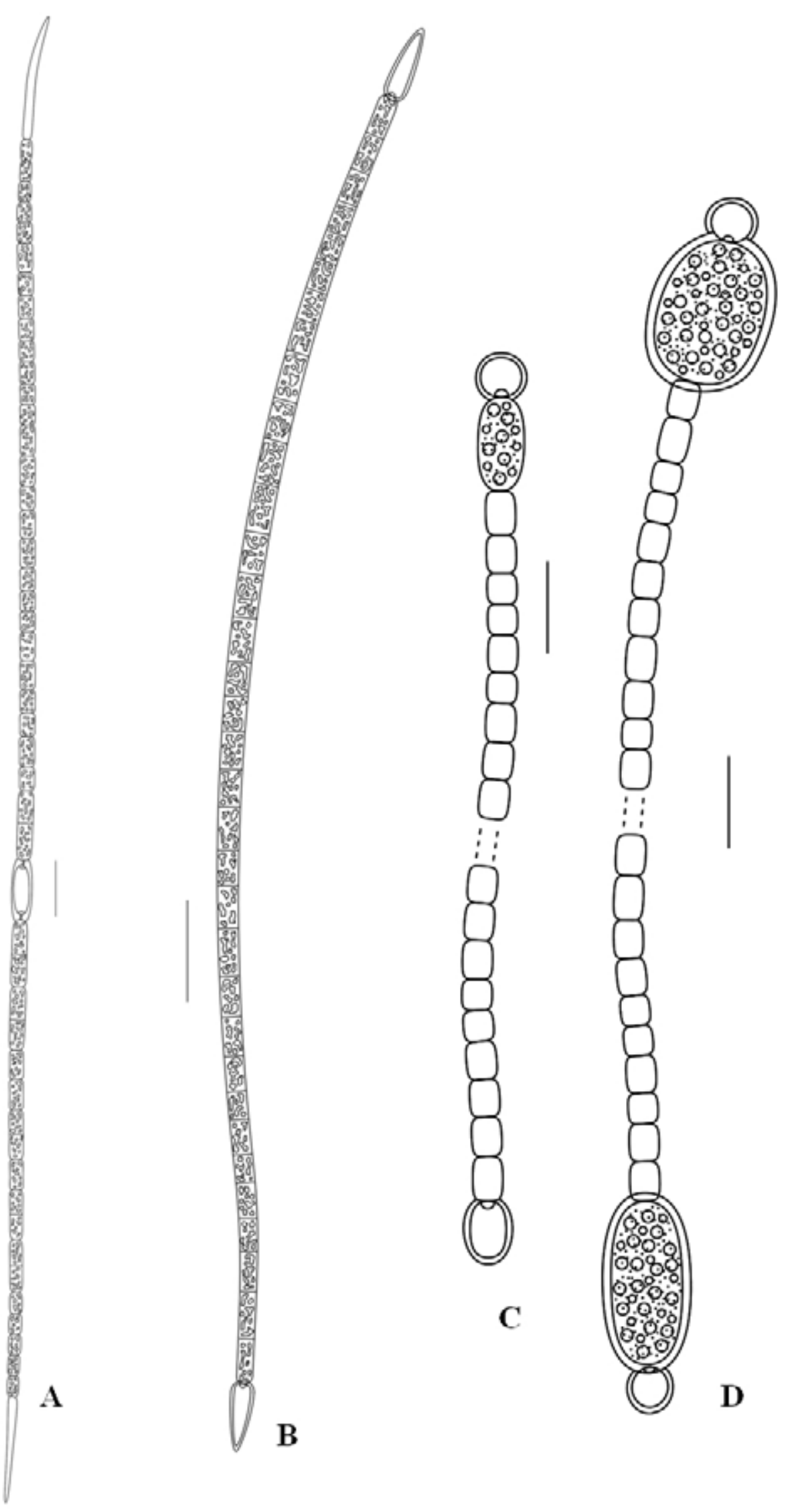

Fig. 26: A-D. A. Cuspidothrix issatschenkoi (Usacev) Rajaniemi et al.; B. Cylindrospenmopsis raciborskii (Wolosynska) Seenayya et Subba Raju; C-D. Cylindrospermuın mucicola Kützing ex Bornet et Flahault. Escalas: $10 \mu \mathrm{m}$. 


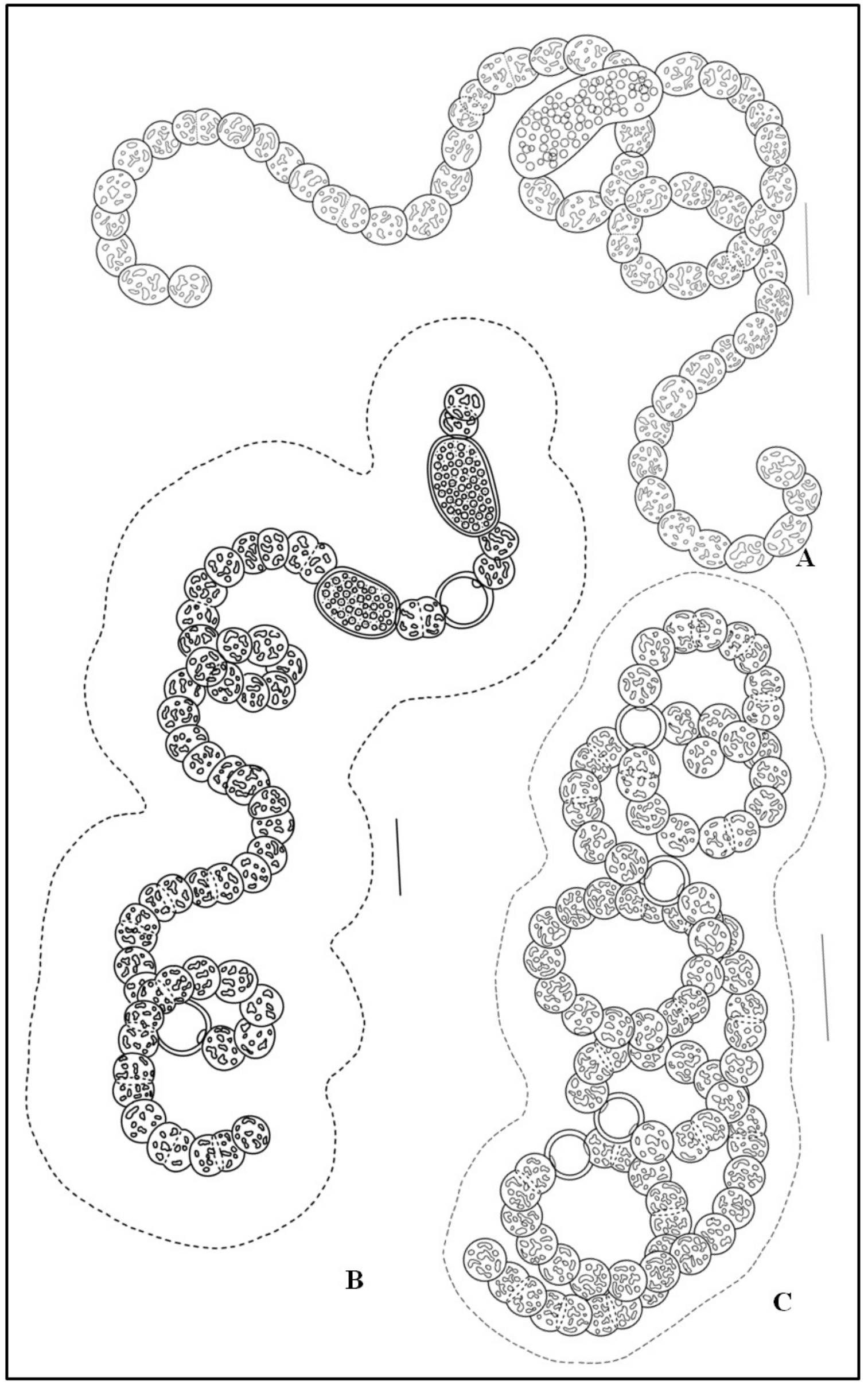

Fig. 27: A-C. A. Dolichospenmum flos-aquae (Lyngby) Wacklin et al.; B. D. crassum (Komárková-Legnerová) Wacklin et al.; C. D. spiroides (Klebahn) Wacklin et al. Escalas: $20 \mu \mathrm{m}$. 


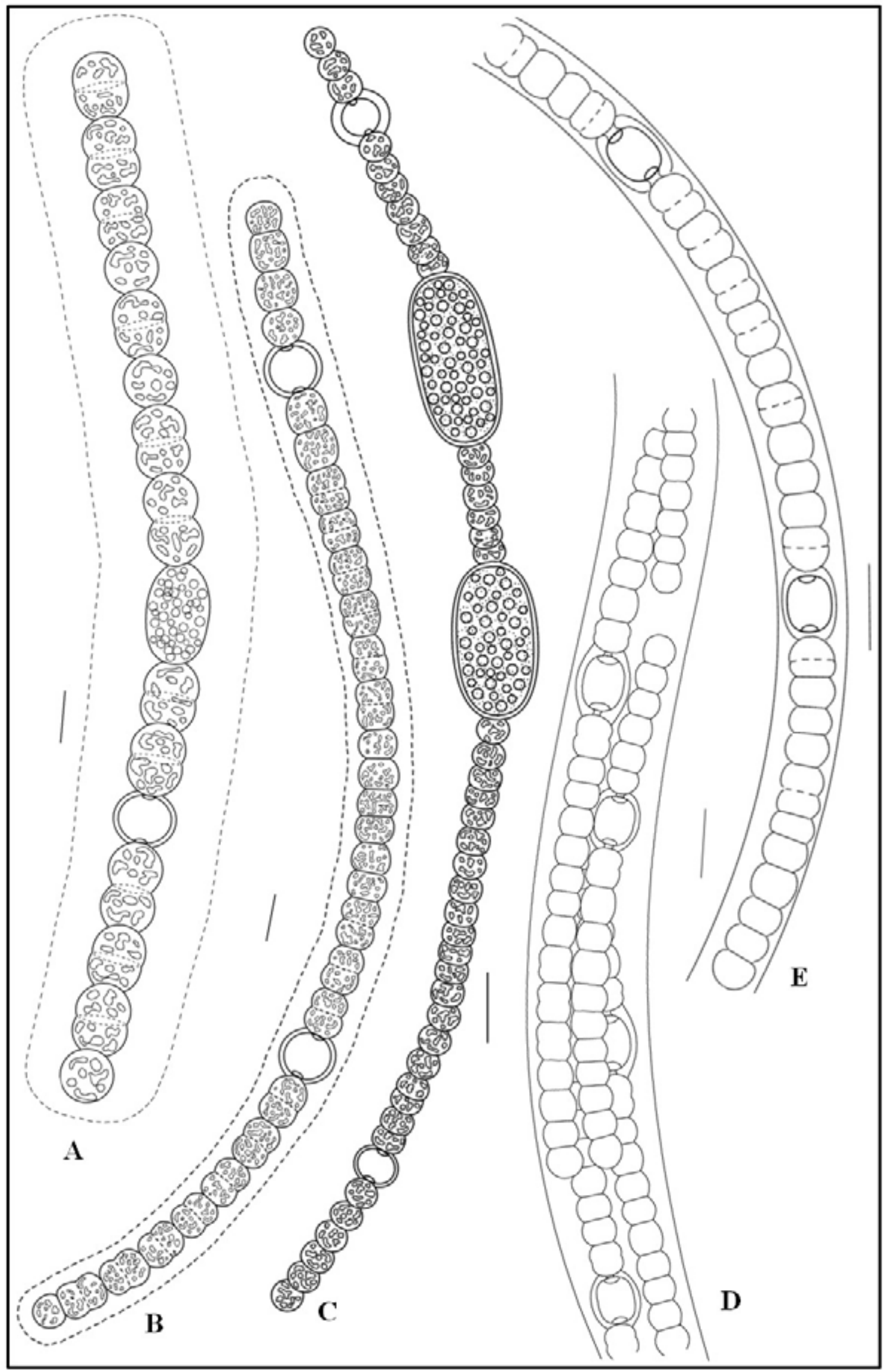

Fig. 28: A-E. A. Dolichospernumn planctonicum (Brunnthaler) Wacklin et al.; B. Dolichospernum cf solitarium (Klebahn) Wacklin et al.; C. D. viguieri (Denis et Frémy) Wacklin et al.; D. Hydroconne sp.; E. Aulosira laxa Kirchner ex Bomet et Flahault. Escalas: $10 \mu \mathrm{m}$. 


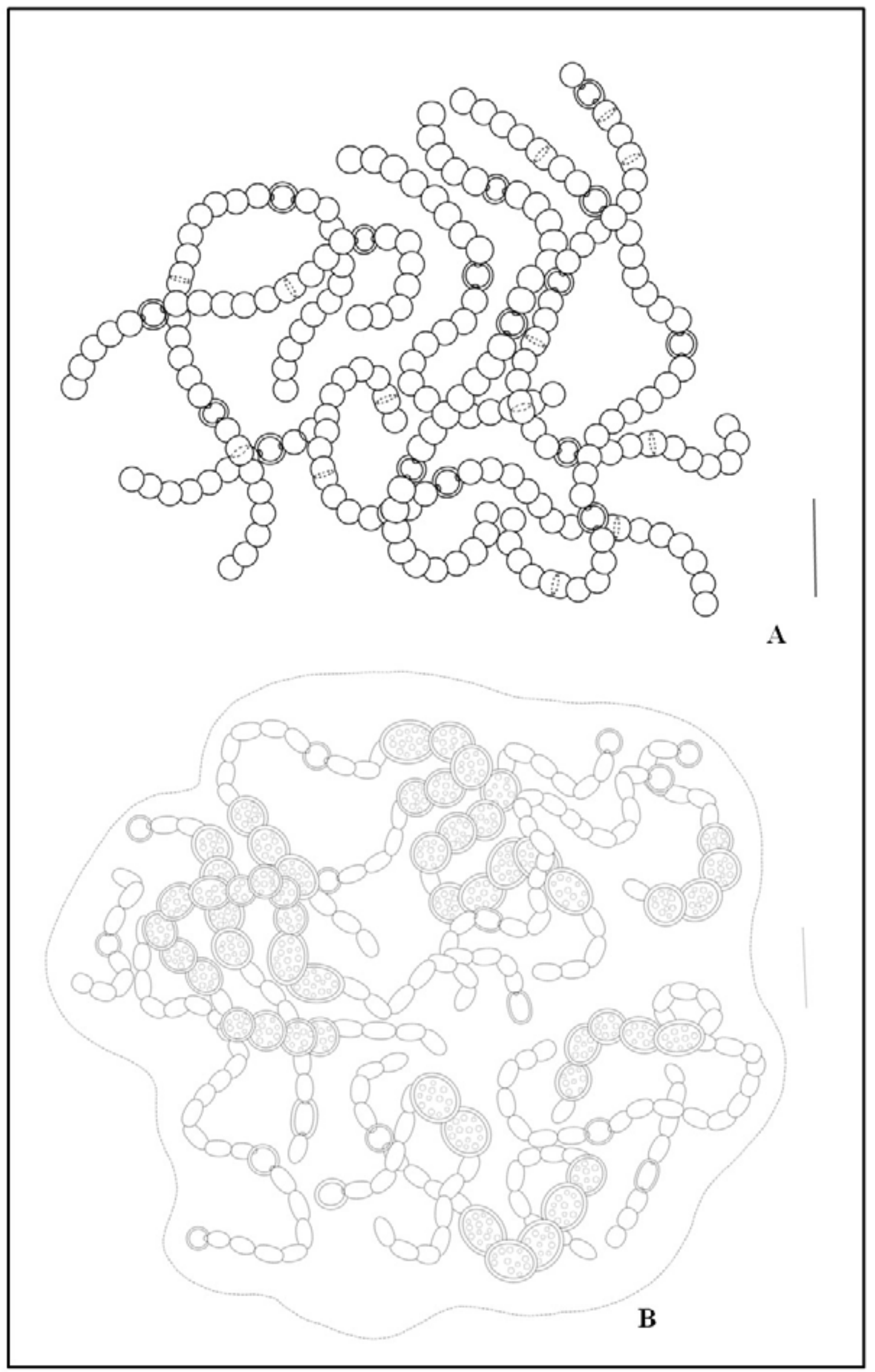

Fig. 29: A-B. A. Nostoc cf. piscinale Kützing ex Bornet et Flahault; B. N. spongiaeforme Agarh ex Bornet et Flahault. Escalas: $20 \mu \mathrm{m}$. 


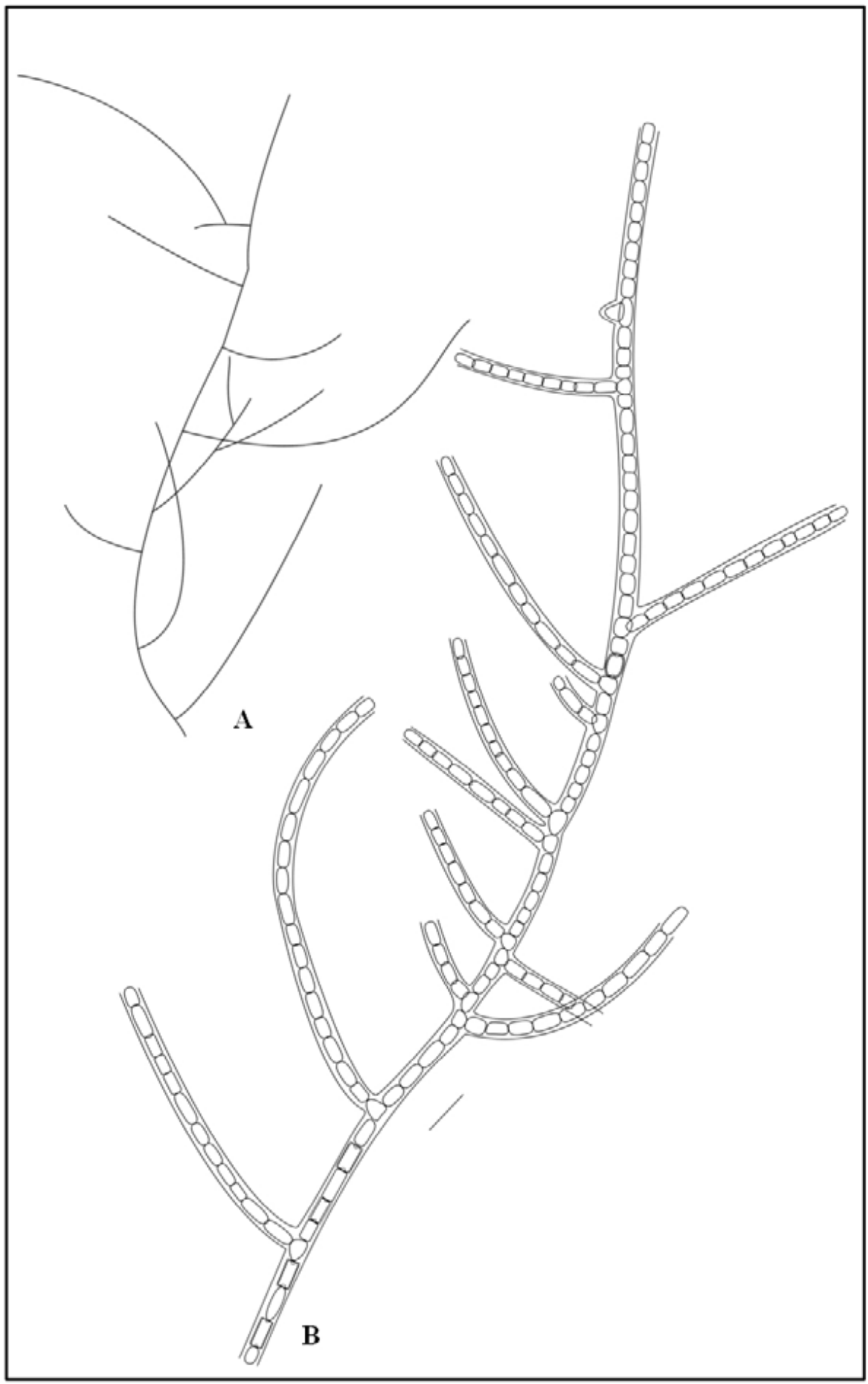

Fig. 30: A-B. Hapalosiphon arboreus W. et G. S. West. A. aspecto geral de um filamento; B. filamento. Escalas: $20 \mu \mathrm{m}$. 


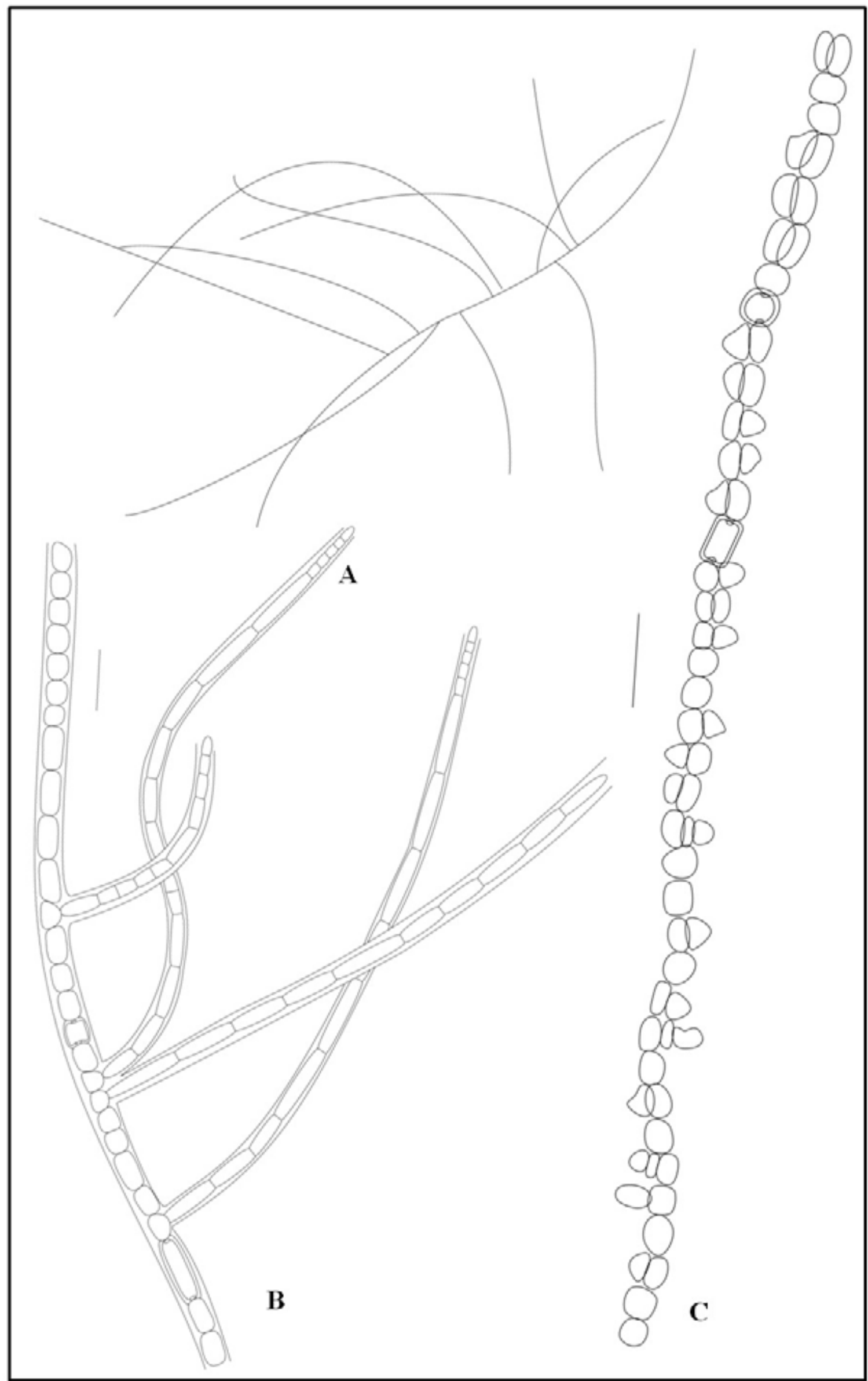

Fig. 31: A-C. A-B. Hapalosiphon hibenicus W. et G. S. West. A. aspecto geral de um filament; B. filamento; C. Hapalosiphon sp. Escalas: $20 \mu \mathrm{m}$. 


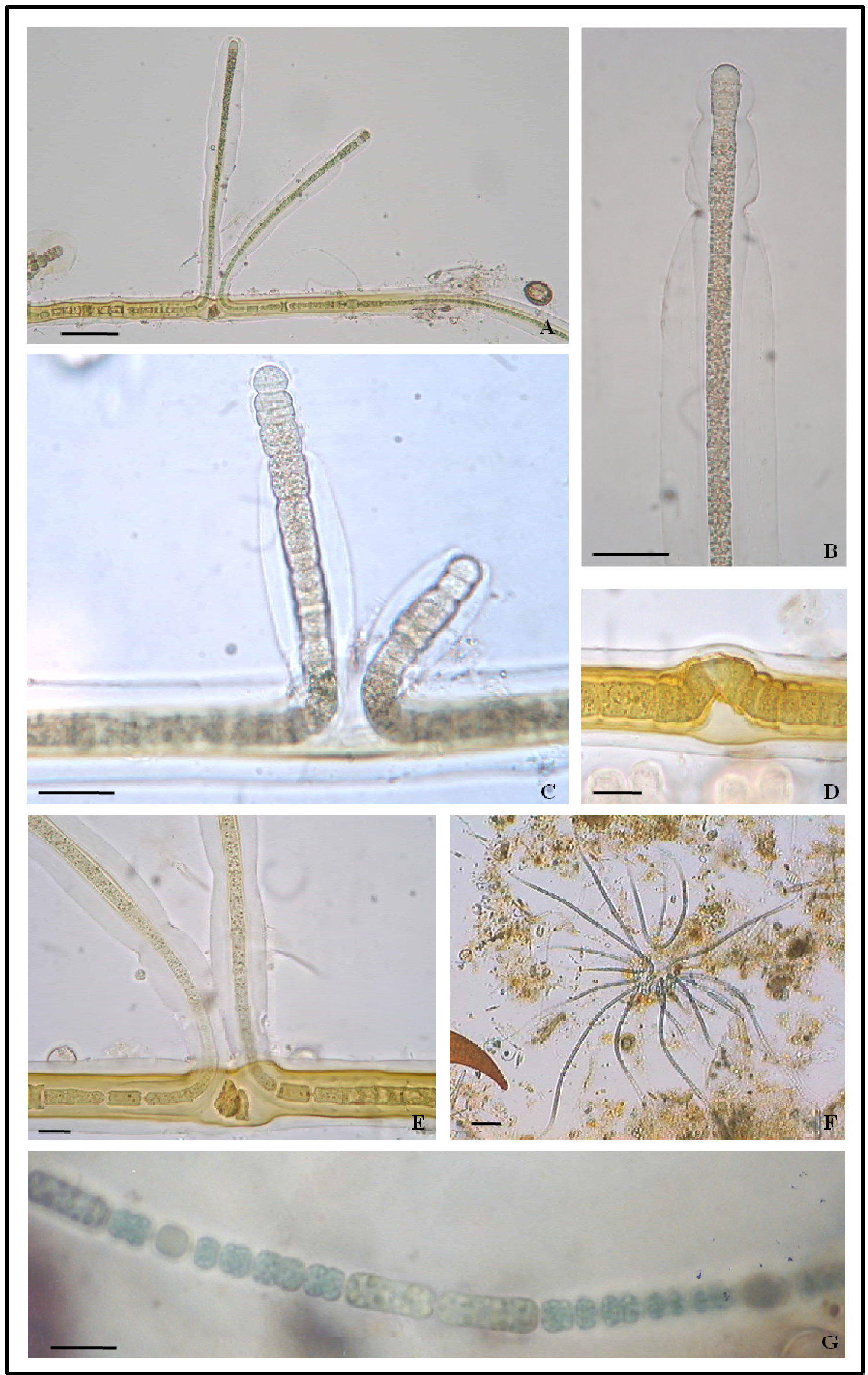

Fig. 32: A-G. A-E. Scrtonema mirabile (D)illwyn) Bomet: F. Gloeonthia longicata Sclumidle: G. Anabaena inatequalis (Kutzing) Bomet et Flahault Escalas: $\mathrm{A}=50 \mu \mathrm{m}: \mathrm{B}-\mathrm{C}=\mathbf{2 0}$

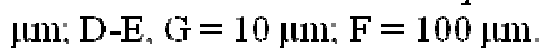




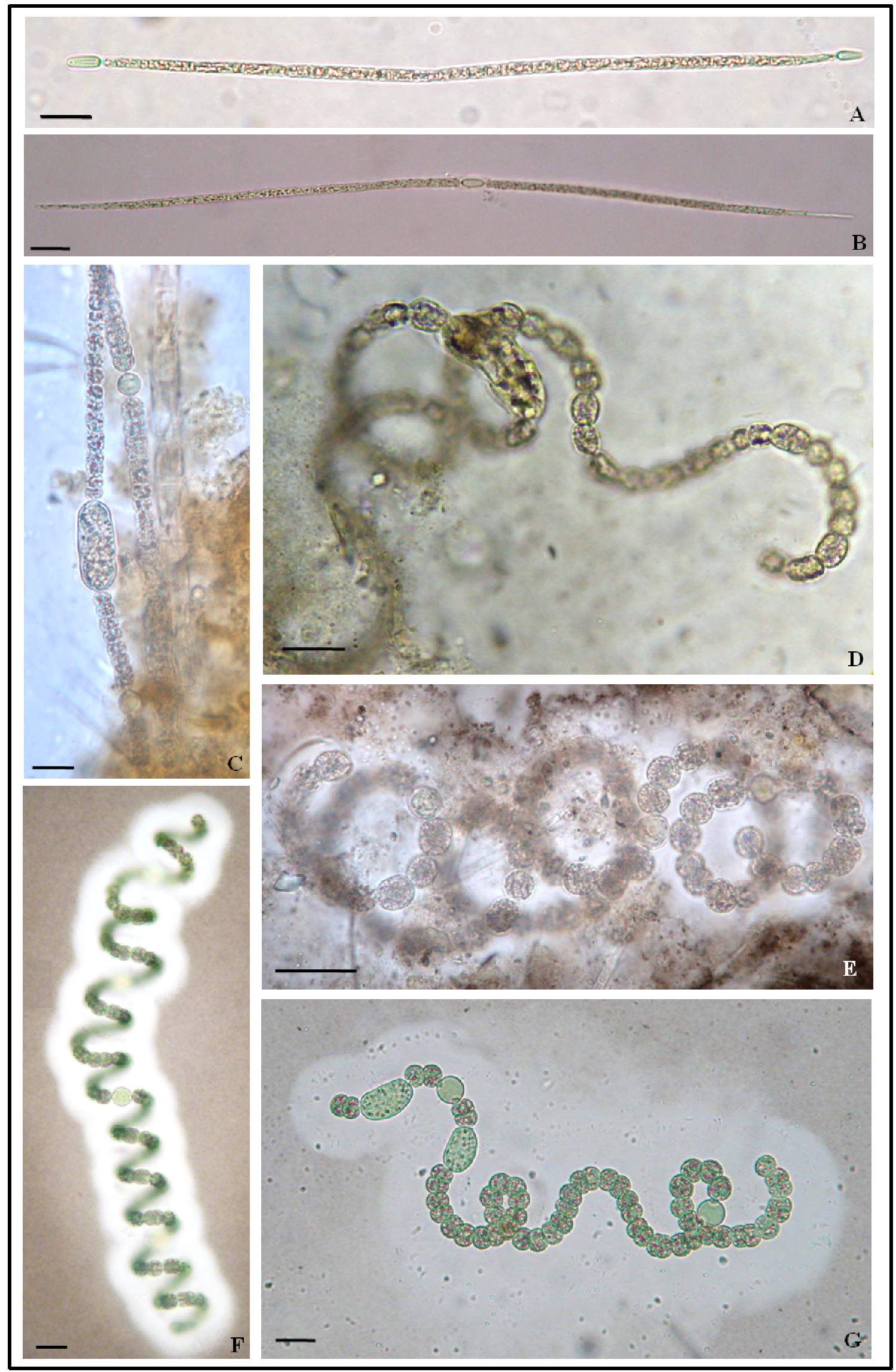

Fig. 33: A-G. A. Cuspidothrix issatschenhoi (Usacev) Rajaniemi et al.; B. Cylindrospermopsis raciborshii (Wolosynska) Seenayya et Subba Raju: C. Dohichospermmm riguteri (Denis et Fremy) Waclilin et al.: D. D) flos-aquace (Lyngby) Waclilin et al.: E. D) spiroides (Klebalun) Waclilin et al.; F-G. I). crasstm (Komathova-Legnerova) Waclilin et al. Escalas: A. E-G $=20$ $\mu \mathrm{m} ; \mathrm{B}-\mathrm{D})=10 \mu \mathrm{m}$. 


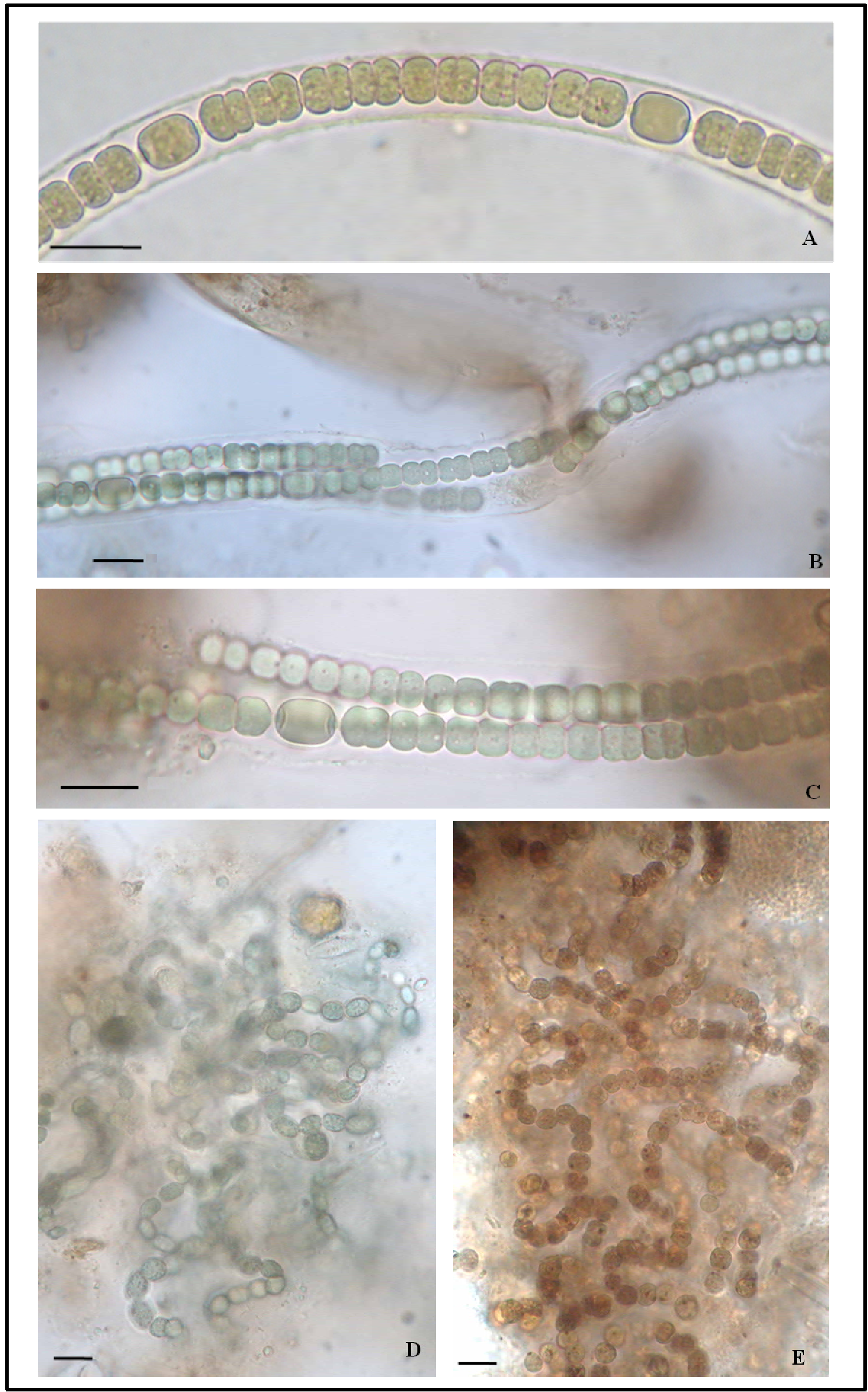

Fig. 34: A-E. A. Allosina lawa Kirclunel ex Bomet et Flahault: B-C. Hydroconthe sp.: D. Nostoc spongicefonme Agardh ex Bomet et Flahault: E. $N$. cf. piscimale Kützing ex Bomet et Flahault. Escalas: $10 \mu \mathrm{m}$. 

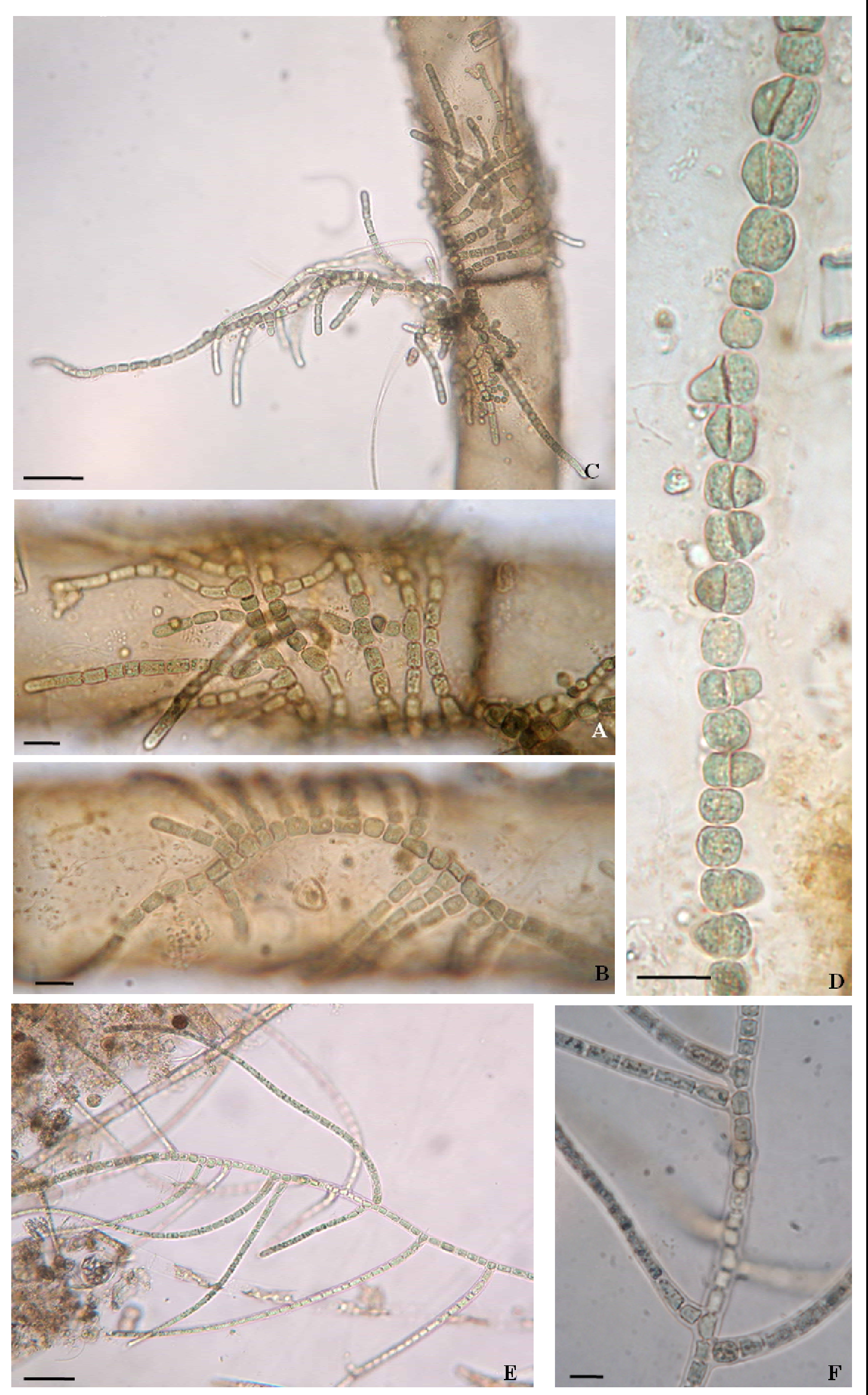

Fig. 35: A-F. A-D. Hapalosiphon sp. E-F. H. aborets W. et G. S. West. Escalas: B-C, D. F $=10 \mu \mathrm{m}$ : $A, E=50 \mu \mathrm{m}$. 


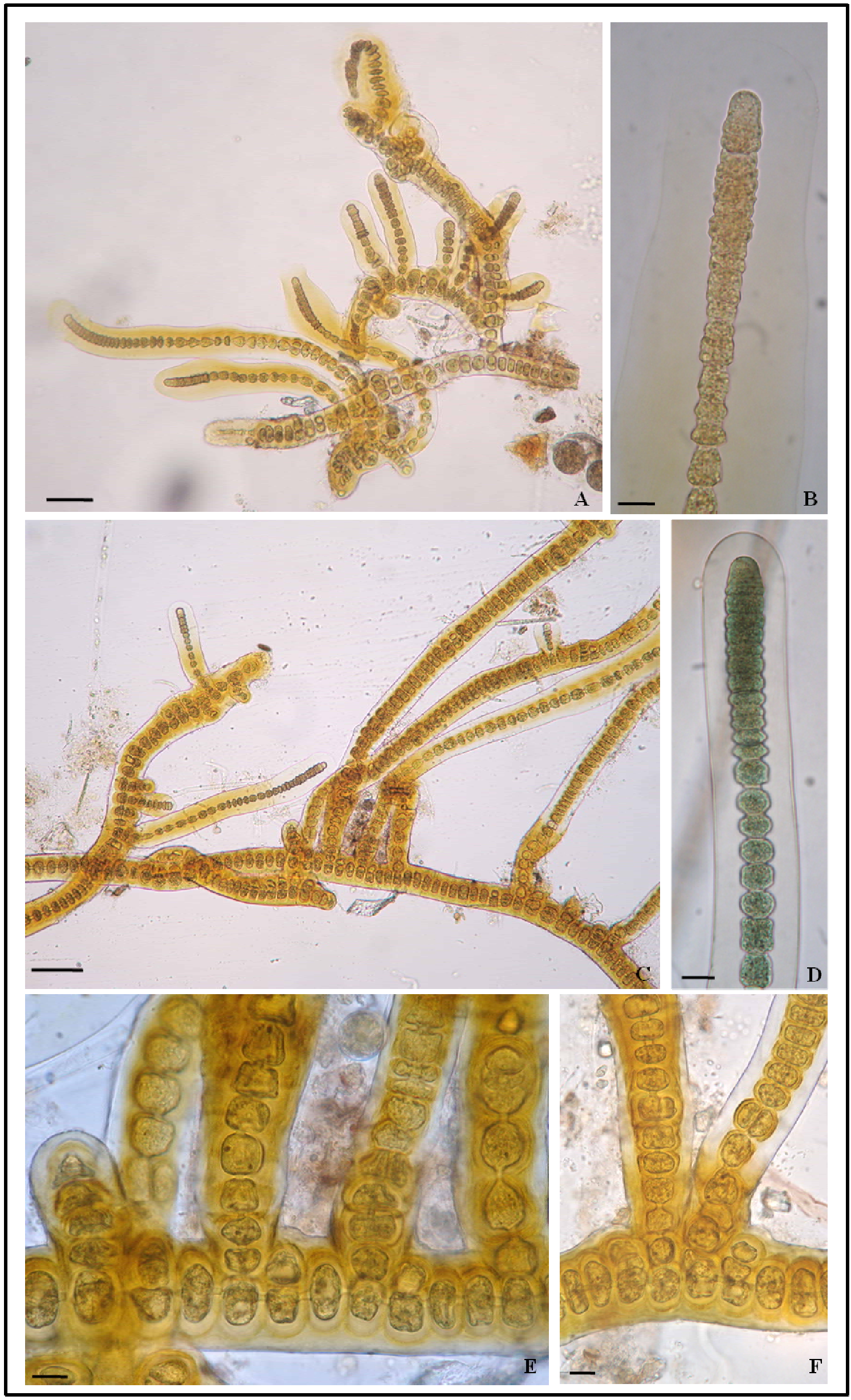

Fig. 36: A-F. Stigonema ocellatmm (D)illwyn) Thuret ex Bomet et Flahault. Escalas: A. C $=50$ jum: B. $\mathrm{D})-\mathrm{F}=10 \mathrm{\mu m}$. 


\section{ASPECTOS ECOLÓGICOS}

A ocorrência das 92 espécies de cianobactérias encontradas apresentou ampla variação entre os ambientes amostrados (Tabela 22), embora em todos os locais estudados tenham sido encontradas populações representativas do grupo.

Geitlerinema splendidum foi a espécie mais amplamente distribuída, ocorrendo em 11 dos 15 ambientes analisados, seguindo-se Phormidium tergestinum (Kützing) Anagnostidis et Komárek, registrada em 10 ambientes, enquanto 33 espécies tiveram ocorrência registrada em apenas um ambiente dos 15 ambientes amostrados. A lagoa dos Gateados foi o local com maior número de espécies de ocorrência exclusiva, 15.

Os valores de riqueza variaram de 0 a 24 por ponto de amostragem $(12,4 \pm 7,7)$ e de 3 a 45 por ambiente amostrado $(17,9 \pm 11,6)$.

A maior riqueza específica foi registrada na área da lagoa do Casamento, com 79 espécies (48 exclusivas), enquanto na área dos butiazais de Tapes foram registradas 44 espécies (13 exclusivas). Foram observados 31 táxons específicos comuns às duas grandes áreas.

$\mathrm{Na}$ grande área da lagoa do Casamento, a lagoa dos Gateados apresentou maior riqueza, 45 espécies, seguida da lagoa do Casamento, com 40 espécies, e do sangradouro, com 23. Na área dos butiazais de Tapes, a lagoa do Charutão apresentou maior riqueza, 20 espécies, seguida do açude da fazenda São Miguel, com 18 espécies, e da lagoa Redonda, com 16.

As cianobactérias ocorreram sob diferentes condições de temperatura, condutividade, $\mathrm{pH}$, profundidade e Secchi (Tabela 23).

Os maiores valores de temperatura foram registrados no mês de dezembro na lagoa do Charutão $\left(34^{\circ} \mathrm{C}\right)$ e no banhado de Sphagnum $\left(32,5^{\circ} \mathrm{C}\right)$ e o menor valor foi registrado no banhado dos Gateados, no mês de maio $\left(15^{\circ} \mathrm{C}\right)$. O valor médio de temperatura foi de $20,3^{\circ} \mathrm{C}$ $\left( \pm 5,1^{\circ} \mathrm{C}\right)$.

Os valores de condutividade variaram amplamente nos ambientes estudados, apresentando valor médio igual a $108,9\left( \pm 134,4 \mu \mathrm{S} . \mathrm{cm}^{-1}\right)$. O pH não apresentou grande variação, mas o maior valor $(8,8)$ foi registrado na lagoa do Casamento, em maio, e o menor $(4,3)$ no banhado de Sphagnum, em dezembro; o pH médio dos ambientes amostrados foi de $6,6( \pm 0,7)$. 
A lagoa do Casamento apresentou maiores valores de profundidade $(3,5 \mathrm{~m})$ e Secchi $(0,83 \mathrm{~m})$, com valores médios globais de $1,3 \mathrm{~m}( \pm 0.9 \mathrm{~m})$ e $0,5 \mathrm{~m}( \pm 0,5 \mathrm{~m})$, respectivamente.

Os valores para a correlação de Spearman entre as variáveis ambientais e a riqueza de espécies não foram estatisticamente significativos. Embora os valores de condutividade tenham variado bastante, não mostraram influência aparente na composição florística. Em relação ao $\mathrm{pH}$, embora também não tenha sido observada influência significativamente do $\mathrm{pH}$ na riqueza de espécies, o ambiente com menor valor (banhado de Sphagnum) foi o que apresentou menor riqueza (3 espécies), corroborando com o fato das cianobactérias serem consideradas neutroalcalinas e ocorrerem preferencialmente em ambientes com $\mathrm{pH}$ superior a 6,0 (WHITTON \& POTTS, 2000b).

A diferença da composição florística entre todas as comunidades de cianobactérias dos ambientes estudados foi medida por meio da diversidade beta $(\beta w)$ e foi igual a 4,13 . A grande área da lagoa do Casamento apresentou diversidade beta menor $(2,20)$ que a da área dos butiazais de Tapes $(2,67)$, mostrando que, apesar da menor riqueza da área dos butiazais de Tapes, as comunidades de cianobactérias são mais heterogêneas. O mesmo parâmetro também foi mensurado comparando-se pares de ambientes, utilizando-se o índice de Jaccard (Tabela 24). Os ambientes que apresentaram maior similaridade na composição de espécies foram a lagoa do Casamento e o banhado dos Gateados e a lagoa do Casamento e o sangradouro $(1-\mathrm{Cj}=0,63)$. Os ambientes com menos similaridade foram a lagoa do Capivari e a lagoa das Capivaras, a lagoa do Capivari e o banhado de Sphagnum, a lagoa do Capivari e o arroio Araçá e o banhado de Sphagnum e o banhado entre dunas $(1-\mathrm{Cj}=1,0)$.

As análises realizadas (Fig. 37) revelaram baixa similaridade na composição de espécies entre os ambientes amostrados, até mesmo entre os que compõem a área da lagoa do Casamento, fato não esperado, devido à interligação entre todos os corpos d'água desta região durante a estação chuvosa. No entanto, os ambientes pertencentes à área dos butiazais de Tapes posicionaram-se distantes uns dos outros e sem comunicação, podendo isto, explicar a baixa similaridade entre os ambientes amostrados. Portanto, a heterogeneidade na composição florística ressalta a necessidade de preservação das áreas estudadas, garantindo a sobrevivência de diferentes comunidades de cianobactérias.

Assim, os organismos e comunidades considerados no presente estudo representam importantes elementos no funcionamento dos sistemas ecológicos, pois fazem parte da base da cadeia alimentar e estão vinculados a processo biogeoquímicos relevantes. 
$\stackrel{\infty}{g}$

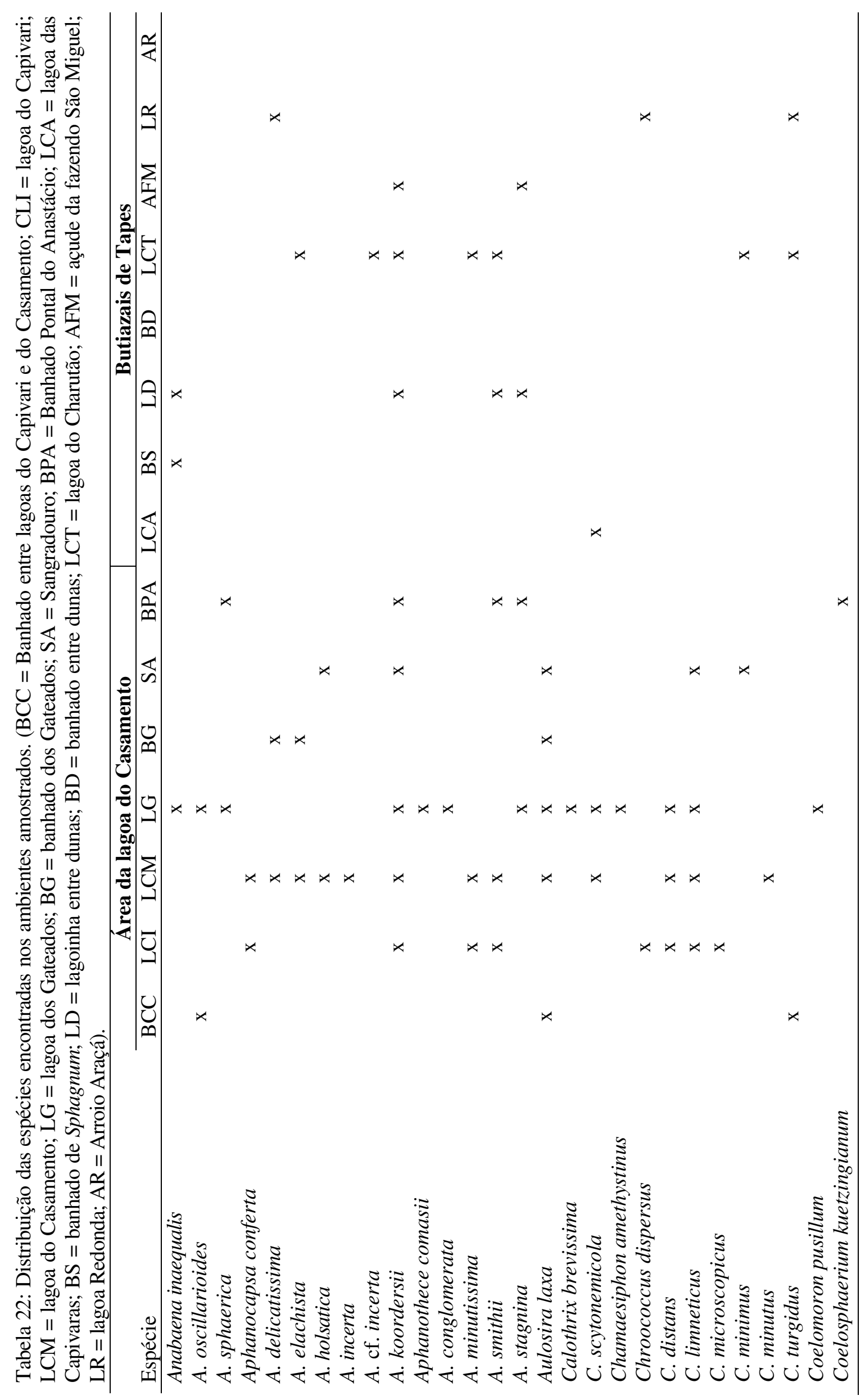




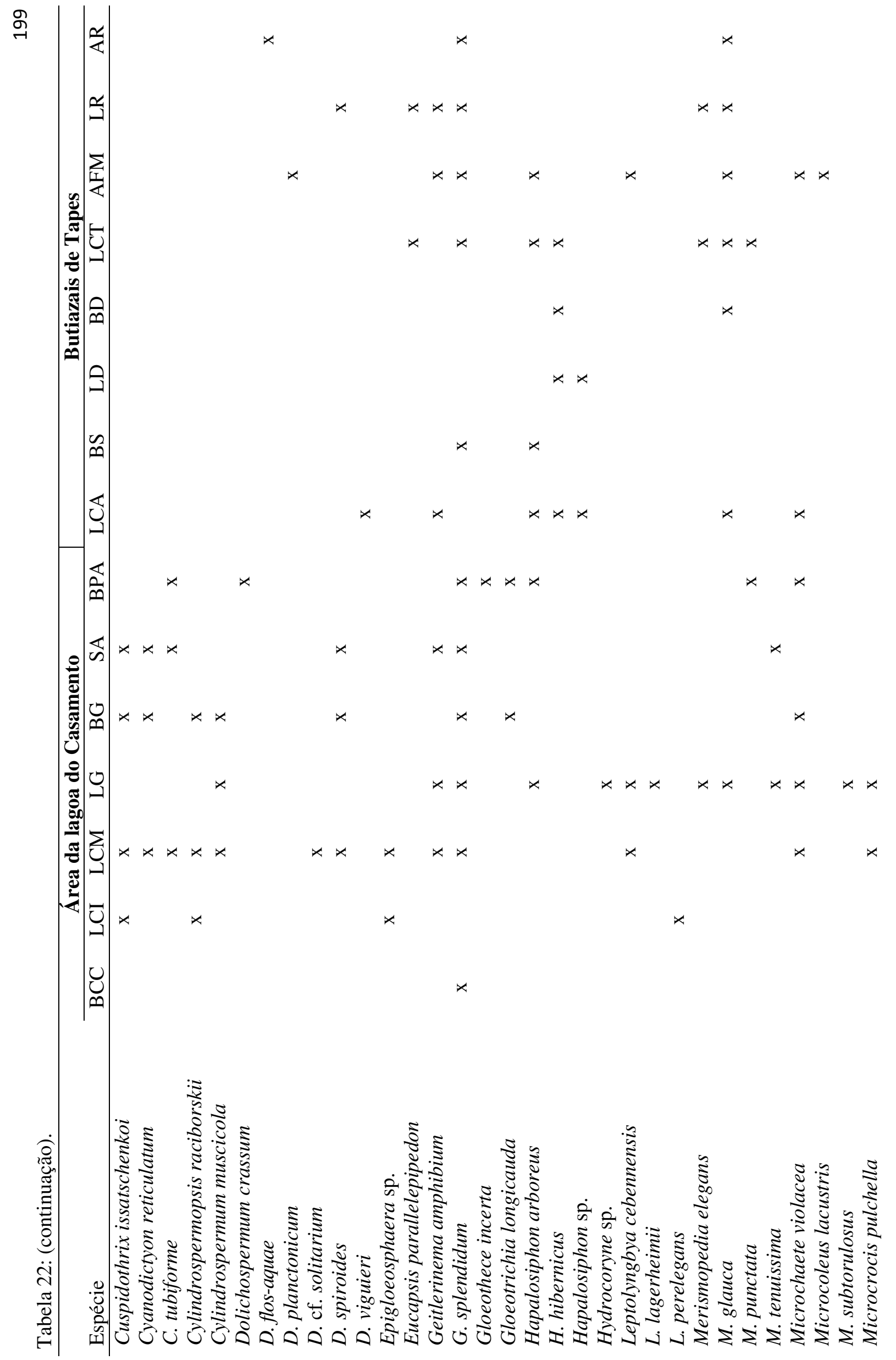


웅

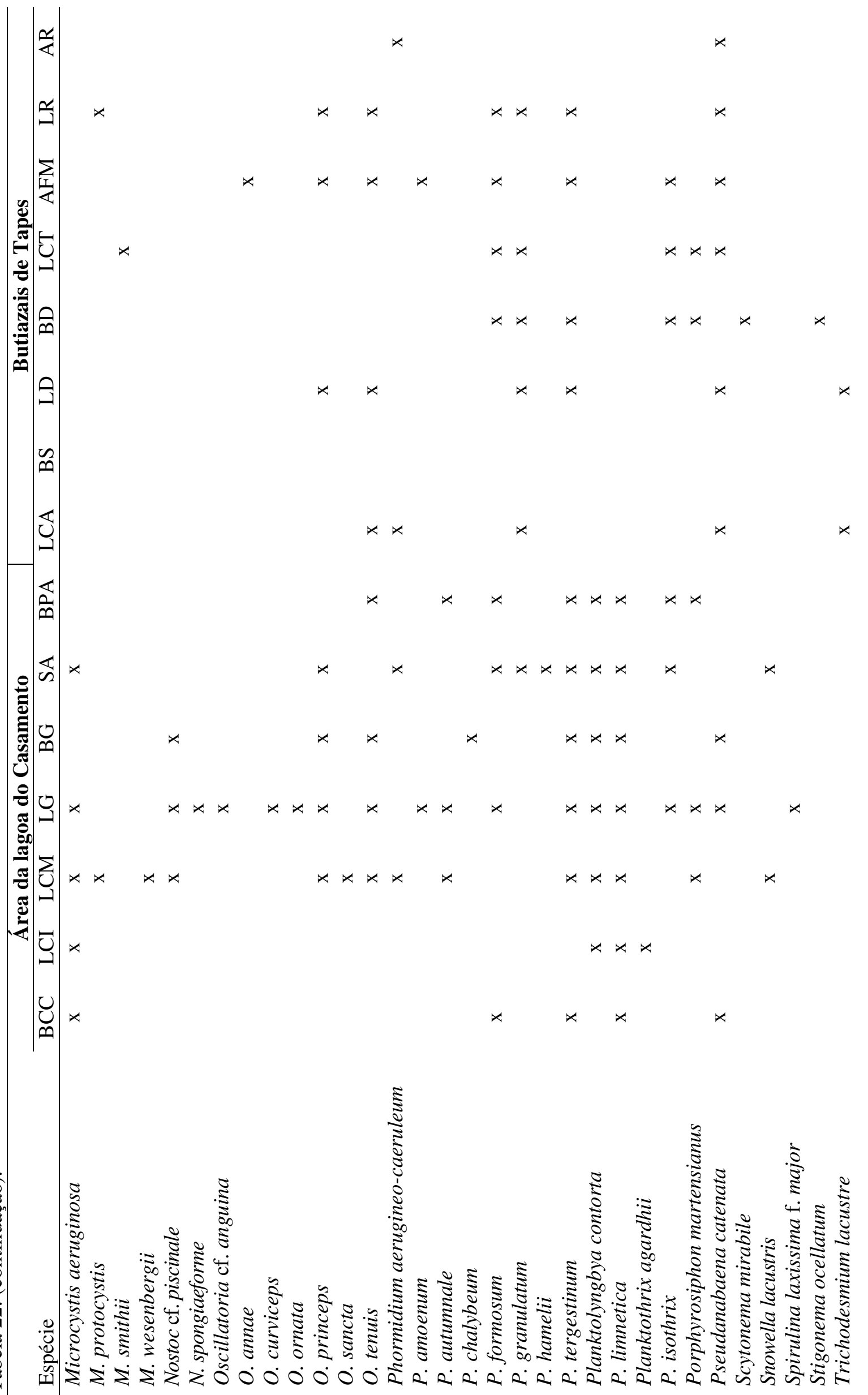


Tabela 23: Fatores abióticos selecionados dos ambientes onde os organismos foram coletados. $(\mathrm{BCC}=$ Banhado entre lagoas do Capivari e do Casamento; CLI = lagoa do Capivari; LCM = lagoa do Casamento; LG = lagoa dos Gateados; BG = banhado dos Gateados; $\mathrm{SA}=$ Sangradouro; BPA = Banhado Pontal do Anastácio; LCA = lagoa das Capivaras; BS = banhado de Sphagnum; $\mathrm{LD}=$ lagoinha entre dunas; $\mathrm{BD}=$ banhado entre dunas; LCT = lagoa do Charutão; AFM = açude da fazendo São Miguel; LR = lagoa Redonda; AR = Arroio Araçá).

\begin{tabular}{ccccc}
\hline Ambientes & $\mathrm{pH}^{1}$ & $\begin{array}{c}\text { Condutividade }^{2} \\
\left(\mu{\left.\mathrm{S} . \mathrm{cm}^{-1}\right)}^{\text {Profundidade }}{ }^{3}\right.\end{array}$ & $\begin{array}{c}\text { Secchi }^{4} \\
(\mathrm{~m})\end{array}$ \\
\hline BCC & 6,6 & 81 & 0,2 & 0,15 \\
LCI & 6,7 & 107 & 2,7 & 0,35 \\
LCM & 7,4 & 84,4 & 1,9 & 0,43 \\
LG & 6,6 & 388,6 & 1,2 & 0,41 \\
BG & 6,5 & 133,5 & 0,75 & 0,1 \\
SA & 6,2 & 11,2 & 2,1 & 0,5 \\
BPA & 6,6 & $*$ & 0,45 & 0,25 \\
LCA & 6,4 & 27,3 & 2 & 1,8 \\
BS & 5,4 & 39,1 & $*$ & 0,8 \\
LD & 6,4 & 30,4 & 0,8 & $*$ \\
BD & 6,1 & 51,2 & $*$ & 0,25 \\
LCT & 7,1 & 24 & 1,3 & $*$ \\
AFM & $*$ & $*$ & $*$ & 0,55 \\
LR & 6,6 & 14,3 & 0,65 & $*$ \\
AR & $*$ & $*$ & $*$ & \\
\hline
\end{tabular}

${ }^{1} \mathrm{pH}=$ Média dos valores de $\mathrm{pH}$ encontrados nos ambientes amostrados.

${ }^{2}$ Média dos valores de condutividade encontrados nos ambientes amostrados.

${ }^{3}$ Média dos valores de profundidade encontrados nos ambientes amostrados.

${ }^{4}$ Média dos valores de Secchi encontrados nos ambientes amostrados.

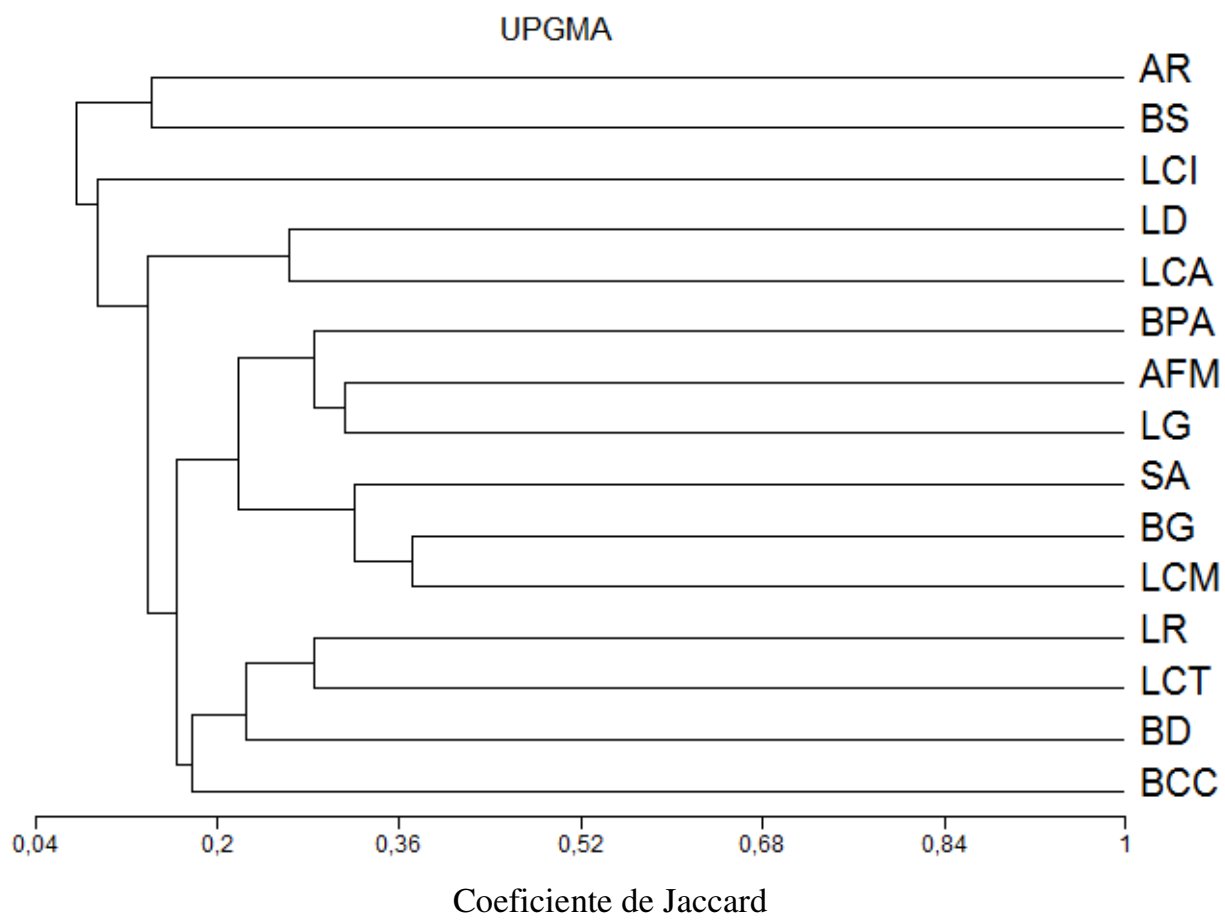

Fig. 37: Dendrograma com base em matriz qualitativa (presença/ausência de espécies) nos 15 ambientes amostrados. 
Tabela 24: Valores de diversidade beta, mensurados a partir do inverso do índice de Jaccard. $(\mathrm{BCC}=$ Banhado entre lagoas do Capivari e do Casamento; CLI = lagoa do Capivari; LCM = lagoa do Casamento; LG = lagoa dos Gateados; BG = banhado dos Gateados; $\mathrm{AS}=$ Sangradouro; BPA = Banhado Pontal do Anastácio; LCA = lagoa das Capivaras; BS = banhado de Sphagnum; LD = lagoinha entre dunas; $\mathrm{BD}=$ banhado entre dunas; LCT = lagoa do Charutão; AFM = açude da fazendo São Miguel; LR = lagoa Redonda; $\mathrm{AR}=$ Arroio Araçá)

\begin{tabular}{llllllllllllllll}
\hline & BCC & LCI & LCM & LG & BG & SA & BPA & LCA & BS & LD & BD & LCT & AFM & LR & AR \\
\hline BCC & 0,0 & 0,91 & 0,89 & 0,83 & 0,78 & 0,77 & 0,85 & 0,95 & 0,91 & 0,89 & 0,87 & 0,86 & 0,83 & 0,75 & 0,83 \\
LCI & 0,0 & 0,73 & 0,89 & 0,87 & 0,82 & 0,88 & 1,0 & 1,0 & 0,92 & 1,0 & 0,91 & 0,97 & 0,97 & 1,0 \\
LCM & & 0,0 & 0,69 & 0,63 & 0,63 & 0,78 & 0,90 & 0,98 & 0,89 & 0,96 & 0,89 & 0,84 & 0,83 & 0,95 \\
LG & & & 0,0 & 0,79 & 0,76 & 0,73 & 0,86 & 0,93 & 0,86 & 0,90 & 0,84 & 0,69 & 0,83 & 0,37 \\
BG & & & & 0,0 & 0,76 & 0,79 & 0,92 & 0,95 & 0,85 & 0,96 & 0,92 & 0,81 & 0,75 & 0,91 \\
AS & & & & & 0,0 & 0,81 & 0,91 & 0,96 & 0,87 & 0,86 & 0,84 & 0,79 & 0,78 & 0,92 \\
BPA & & & & & & 0,0 & 0,90 & 0,91 & 0,82 & 0,85 & 0,76 & 0,72 & 0,88 & 0,96 \\
LCA & & & & & & & 0,0 & 0,93 & 0,68 & 0,84 & 0,82 & 0,76 & 0,79 & 0,80 \\
BS & & & & & & & & 0,0 & 0,93 & 1,0 & 0,90 & 0,89 & 0,94 & 0,86 \\
LD & & & & & & & & & 0,0 & 0,83 & 0,81 & 0,75 & 0,78 & 0,94 \\
BD & & & & & & & & & & 0,0 & 0,74 & 0,83 & 0,81 & 0,92 \\
LCT & & & & & & & & & & & 0,0 & 0,77 & 0,71 & 0,86 \\
AFM & & & & & & & & & & & & 0,0 & 0,69 & 0,85 \\
LR & & & & & & & & & & & & & 0,0 & 0,83 \\
AR & & & & & & & & & & & & & & 0,0 \\
\hline
\end{tabular}




\section{CONSIDERAÇÕES FINAIS}

Os resultados obtidos mostram a ocorrência de 92 espécies de cianobactérias, pertencentes a 39 gêneros, nos sistemas lacustres das áreas da lagoa do Casamento e dos Butiazais de Tapes, Planície Costeira do estado do Rio Grande do Sul.

A subclasse Synechococcophycidae foi representada por 34 espécies (37\%), Oscillatoriophycidae por 33 (36\%) e Nostocophycidae por $25(27 \%)$.

Os táxons específicos identificados na subclasse Synechococcophycidae, pertencem à ordem Synechococcales (Synechococcaceae [9], Merismopediaceae [15] e Chamaesiphonaceae [1]) e à ordem Pseudanabaenales (Pseudanabaenaceae [9]); os táxons pertencentes à subclasse Oscillatoriophycidae estão divididos nas ordens Chroococcales (Microcystaceae [5] e Chroococcaceae [7]) e Oscillatoriales (Phormidiaceae [13] e Oscillatoriaceae [8]); os táxons pertencentes à subclasse Nostochophycidae pertencem à ordem Nostocales (Scytonemataceae [1], Rivulariaceae [3], Microchaetaceae [1], Nostocaceae [16], Mastigocladaceae [3] e Stigonemataceae [1]).

Phormidium foi o gênero que apresentou o maior número de táxons específicos identificados, oito espécies (9\%), seguido de Aphanocapsa, Chroococcus e Oscillatoria, com sete espécies (8\% cada um) e Dolichospermum, com seis espécies (6\%).

Entre as espécies identificadas, $24(26 \%)$ são citadas pioneiramente para o estado do Rio Grande do Sul: Anabaena sphaerica Bornet et Flahault, Aphanocapsa elachista West et. G. S. West, Aulosira laxa Kirchner ex Bornet et Flahault, Calothrix scytonemicola Tilden, Chamaesiphon amethystinus (Rostafinski) Lemmermann, Chroococcus minimus (Keissler) Lemmermann, Coelomoron pusillum (Van Goor) Komárek, Coelosphaerium kuetzingianum Nägeli, Cyanodictyon tubiforme Cronberg, Gloeothece incerta Skuja, Gloeotrichia longicauda Schmidle, Hapalosiphon arboreus W. et G. S. West, H. hibernicus West et G. S. West, Leptolyngbya cebennensis (Gomont) Umezaki et M. Watanabe, Microchaete violacea Frémy, Microcoleus lacustris (Rabenhorst) Farlow ex Gomont, M. subtorulosus Gomont ex Gomont, Nostoc cf. piscinalis Kützing ex Bornet et Flahault, Oscillatoria cf. anguina Bory ex Gomont, O. curviceps Agardh ex Gomont, Phormidium amoenum Kützing ex Anagnostidis et Komárek, P. formosum (Bory ex Gomont) Anagnostidis et Komárek, Scytonema mirabile (Dillwyn) Bornet e Stigonema ocellatum (Dillwyn) Thuret ex Bornet et Flahault. 
Os táxons Epigloeosphaera sp., Hapalosiphon sp. e Hydrocoryne sp. não apresentam afinidade com qualquer tipo morfológico já descrito, constituindo-se, provavelmente, novidades para a ciência.

Geitlerinema splendidum foi a espécie documentada no maior número de ambientes estudados, ocorrendo em 11 dos 15 ambientes analisados no presente estudo. Seguiu-se Phormidium tergestinum (Kützing) Anagnostidis et Komárek, registrada em 10 ambientes. Das 92 espécies identificadas, 49 (53\%) foram encontradas somente em lagoas, cinco (6\%) somente em banhados, enquanto 38 (41\%) foram observadas tanto em lagoas como em banhados. Além disso, 33 espécies foram observadas em apenas um dos 15 ambientes amostrados, destacando-se a lagoa dos Gateados, com 15 espécies de ocorrência exclusiva.

A maior riqueza específica foi registrada na grande área da lagoa do Casamento, com 79 espécies (48 exclusivas), enquanto na grande área dos butiazais de Tapes foram registradas 44 espécies (13 exclusivas). Foram observados 31 táxons específicos tanto na área da lagoa do Casamento como na área dos butiazais de Tapes.

Entre todos os ambientes amostrados, a lagoa dos Gateados apresentou maior riqueza, 45 espécies, seguida da lagoa do Casamento, com 40 espécies.

Com base na particularidade florística dos diferentes ambientes estudados, destaca-se a importância da preservação desses sistemas, também visando a manutenção da elevada biodiversidade das cianobactérias que compõem as comunidades aquáticas locais. 


\section{REFERÊNCIAS BIBLIOGRÁFICAS}

ADAMS, D. G. Symbiotic Interations. In: WHITTON, B. A.; POTTS, M. (Ed.) The ecology of Cyanobacteria. Their diversity in time and space. Dordrecht: Kluwer Academic, 2000. cap. 19 , p. 523-561.

ANAGNOSTIDIS, K. Geitlerinema, a new genus of osillatorialean cyanophytes. Pl. Syst. Evol., Vienna, 164, p. 33-46. 1989.

ANAGNOSTIDIS, K.; KOMÁREK, J. Modern approach to the classification system of cyanophytes. 1 - Introduction. Algological Studies, Stuttgart, v. 38-39, p. 291-302. 1985.

Modern approach to the classification system of cyanophytes 3 - Oscillatoriales. Arch. Hydrobiol./Suppl. v. 80, n. 1-4, Algol. Studies, Stuttgart, v. 50-53, p. 327-472, 1988.

Modern approach to the classification system of cyanophytes 5 - Stigonematales. Algol. Studies, Stuttgart, v. 79, p. 1-73, 1990.

ASENCIO, A. D; ABOAL, M. Cyanophytes from Andragulla abrigo (Murcia, SE Spain) and their environmental conditions. Algol. Studies, Stuttgart, v. 83, p. 55-72, 1996.

AYRES, M.; AYRES, M. J.; AYRES, D. L.; SANTOS, A. S. BioEstat 4.0: aplicações estatísticas nas áreas das ciências biomédicas. Belém: Sociedade Civil Mamirauá, Brasília, Ministérios da Ciêncie a Tecnologia; Belém Imprensa Oficial do Estado do Pará, 2005. 324p.

AZEVEDO, M. T. P. Edaphic blue-green algae from the São Paulo Botanical Garden, Brazil. Algol. Studies, Stuttgart, v. 64, p. 503-526, 1991.

AZEVEDO, M. T. P.; NOGUEIRA, N. M. C.; SANT'ANNA, C. L. Criptógamas no Parque Estadual das Fontes do Ipiranga, São Paulo, SP. Algas, 8: Cyanophyceae. Hoehnea, São Paulo, v. 23, n. 1, p. 1-38, 1996.

AZEVEDO, M.T.P.; SANT'ANNA, C.L.; SENNA, P.A.C.; KOMÁREK, J. and KOMÁRKOVÁ, J. Contribution to the microflora of chroococcalean cyanoprokaryotes from São Paulo State, Southeast Brazil. Hoehnea, São Paulo, v. 30, n. 3, p.285-295, 2003. 
AZEVEDO, M. T. P; SOUZA, C. A.; MENEZES, M. Synechococcaceae (Cyanophyceae/Cyanobacteria) from a tropical brackish water lagoon, Brazil. Algol. Studies, Stuttgart, v. 94, p. 45-61, 1999.

BAETA NEVES, M. H. B. Flora ficológica da lagoa hipersalina de Araruama (Estado do Rio de Janeiro - Brasil) 2. Cyanophyceae. Publicação do Instituto de Pesquisa da Marinha, Rio de Janeiro, n. 149, p. 1-15, 1983.

Estudo das cianofíceas marinhas bentônicas da região de Cabo Frio (Rio de Janeiro, Brasil) I - Chroococcales. Hoehnea, São Paulo, v. 18, n. 1, p. 191-204, 1991.

Estudo das cianofíceas marinhas bentônicas da região de Cabo Frio (Rio de Janeiro, Brasil) II - Hormogonae. Revta bras. Biol., Rio de Janeiro, v. 52, n. 4, p. 641659, 1992.

BAKER, P. D. et al. Preliminary evidence of toxicity associated with the benthic cyanobacterium Phormidium in south Australia. Environm. Toxicol., New York, v. 16, n. 6, p. 506-511, 2001.

BECKER, F. G.; RAMOS, R. A.; MOURA, L. A. Introdução. In: Biodiversidade do

Rio Grande do Sul: regiões da lagoa do Casamento e dos Butiazais de Tapes, planície costeira do Rio Grande do Sul. Brasília, 2007. Cap. 1, p. 10-19.

BERG, K. et al. Observations of toxic blue-green algae (cyanobacteria) in some Scandinavian lakes. Acta vet. scand., Copenhagen, v. 27, p. 440-452, 1987.

BICUDO, C. E. M.; BICUDO, R. M. T. Algas da Lagoa das Prateleiras, Parque Nacional do Itatiaia, Brasil. Rickia, São Paulo, v. 4, p. 1-40, 1969.

BICUDO, C. E. M.; VENTRICE, M. R. 1968. Algas do brejo da Lapa, Parque Nacional do Itatiaia, Brasil. In: CONGRESSO NACIONAL DE BOTÂNICA, 19., 1968, Fortaleza: Anais... Fortaleza: Sociedade Botânica do Brasil. 1968. p. 3-30.

BITTENCOURT-OLIVEIRA, M.; MOLICA, R. J. R. Cianobactéria invasora - Aspectos moleculares e toxicológicos da Cylindrospermopsis raciborskii no Brasil. Revista Biotecnologia, Ciência e Desenvolvimento, Brasília, v. 30, p. 82-90, 2003.

BOONE, D. R.; CASTENHOLZ, R. W.; GARRITY, G. M. Bergey's manual of systematic bacteriology. 2 ed. New York: Springer-Verlag, 2001, v. 1, 721p. 
BORNET, E.; FLAHAULT, C. Révision des Nostocacées hétérocystées, contenues dans les principaux herbiers de France. Ann. Sci. nat. Bot., Paris, v. 1, sér. 3, p. 323-381; sér. 4, p. 343-373; ser. 5, p. 51-129; sér.. 7, p. 177-262, 1886-1888.

BOROWITZKA, M. A. Microalgae as source of pharmaceuticals and other biologically active compounds. J. Appl. Phycol., Dordrecht, v. 7, n. 1, p. 3-15, 1995.

BOURRELLY, P. Les algues d'eau douce: initiation à la systématique. Les algues bleues et rouges. Paris: Boubée. v. 3, 512p, 1970a.

$\frac{}{1970 b .}$. Note sur la famille des Oscillatoriacées. Schweiz. Z. Hydrol., Paris, v. 32, p. 519-522,

Les algues d'eau douce: III. Paris: Boubée. 606p, 1985.

BRANCO, C. W. C. A comunidade planctônica e a qualidade da água no lago Paranoá, Brasília, DF, Brasil. 1991. 341 f. Dissertação (Mestrado em Ecologia), Departamento de Ecologia, Universidade de Brasília, Brasília.

BRANCO, L. H. Z; NECCHI, O. Jr.; BRANCO, C. C. Z. Cyanophyte flora from Cardoso Island mangroves, São Paulo State, Brazil. 1. Chroococcales. Algol. Studies, Stuttgart, v. 80, p. $99-111,1996$.

BRANCO, L. H. Z.; PEREIRA, J. L. Evaluation of macroalgal communities along a gradient of organic pollution in a tropical stream. Arch. Hydrobiol., Stuttgart, v. 115, p. 147-161, 2002 .

BRANCO, L. H. Z. et al. Cyanophyte flora from Cardoso Island mangroves, São Paulo State, Brazil. 2. Oscillatoriales. Algol. Studies, Stuttgart,v. 84, p. 39-52, 1997.

BRANCO, L. H. Z. et al. Cyanophyceae from lotic ecosystems of São Paulo State, southeastern Brazil. Algol. Studies, Stuttgart, v. 94, p. 63-87, 1999.

BRASIL. Avaliação e Ações Prioritárias para Conservação da Biodiversidade das Zonas Costeira e Marinha. Fundação BIO-RIO, Secretaria do Estado de Ciência, Tecnologia e Meio Ambiente do Pará, Instituto de Desenvolvimento Econômico e Meio Ambiente do Rio Grande do Norte, Sociedade Nordestina de Ecologia et al. Brasília, MMA/SBF. 2002, 72p. 
BRIAND, J. F.; ROBILlOT, C.; QUIBLIER-LLOBERAS, C.; BERNARD, C. A perennial bloom of Planktothrix agardhii (Cyanobacteria) in a shallow eutrophic French lake: limnological and microcystin production studies. Arch. Hydrobiol. Stuttgart, v. 153, n. 4, p. 605-622, 2002.

BUCKA, H.; WILK-WOZNIAK, E. A contribution to the knowledge of some potentially toxic cyanobacteria species forming blooms in water bodies - chosen examples. Oceanol. Hydrobiol. Studies, Gdansk, v. 34, n. 3, p. 43-53, 2005.

BUELL, H. F. The taxonomy of a community of blue-green algae in a Minnesota pond. Bull. Tor. Bot. Club., v. 65, n. 6, p. 377-396, 1938.

BURGER, M. I.; RAMOS, R. A. Áreas importantes para a conservação na planície costeira do Rio Grande do Sul. In: BECKER, F. G.; RAMOS, R. A.; MOURA, L. A. Biodiversidade do Rio Grande do Sul: regiões da lagoa do Casamento e dos Butiazais de Tapes, planície costeira do Rio Grande do Sul. Brasília, 2007. Cap. 4, p. 46-57.

BURGER-WIERSMA, T.; STAL, L. J.; MUR, L. R. Prchlorothrix hollandica gen. nov. sp. nov., a filamentous oxygenic photoautotrophic prokaryote containing chlorophylls a and $b$ : assignment to Prochlorothricaceae fam. Nov. and order Prochlorales Florenzano, Balloni and Materassi, 1986, with emendation of the ordinal description. Int. J. Syst. Bacteriol., London v. 39, p. 250-257, 1989.

CASTENHOLZ, R. W. Cyanobacteria. Oxygenic phothosynthetic bacteria. In: BOONE, D. R.; CASTENHOLZ, R. W. (Ed.). Bergey's manual of systematic bacteriology. 2. ed. New York: Springer-Verlag, 2001. P. 473-599.

CALLEGARO, V. L. M.; ROSA, Z. M.; WERNER, V. R. Comunidades fitoplanctônicas das lagoas de Tramandaí e do Armazém, Rio Grande do Sul, Brasil. Iheringia, Sér. Bot., Porto Alegre, n. 28, p. 3-16, 1981.

CAMPOS, I. F. P. Estudo qualitativo das Nostocophyceae (Cyanophyceae) da lagoa Bonita, Brasília, DF. 1986. 155 f. Dissertação (Mestrado EM Ciências Biológicas Botânica) - Setor de Ciências Biológicas, Universidade Federal do Paraná, Curitiba.

CHORUS, I.; BARTRAM, J. Toxic cyanobacteria in water, a guide to public health consequences, monitoring and management. London: E \& FN Spon. 1999.

COHEN, Y.; JORGENSEN, B. B.; REVSBECH, N. P.; POPLAWSKI, R. Adaptation to hydrogen sulfide of oxygenic and anoxygenic photosynthesis among cyanobacteria. Appl. Environ. Microbiol., Washington, v. 51, n.2, p. 398-407, 1986. 
COMPÈRE, P. Algues du Sahara et de la région du lac Tchad. Bull. Jard. Bot. Natl. Belgique, Bruxelles, v. 37, n. 2, p. 109-288, 1967.

Algaes de La région Du lac Tchad. II - Cyanophycées. Cah ORSTOM, Sér Hydrobiol., v. 8, 3-4, p. 165-198, 1974.

COUTÉ, A.; TELL, G.; THÉREZIÉN, Y. Aerophytic cyanophyceae from New Caledonia. Cryptogamie Algologie. Paris, v. 20, n. 4. p. 301-344, 1999.

CRONBERG, G. Cyanodictyon tubiforme, a new chroococcal blue-green alga from Lake Börringesjön, Scania, Sweden. Arch. Hydrobiol./Suppl., Stuttgart, v. 80, n. 1-4, p. 191-194, 1998.

CRONBERG, G.; KOMÁREK, J. Planktic Cyanoprokaryotes found in South Swedish lakes during the XIIth International Symposium on Cyanophyte Research, 1992. Algolog. Studies, Sttutgart, v. 75, p. 323-352, 1994.

DAVIS, P. A.; DENT, M.; PARKER, J.; REYNOLDS, C. S.; WALSBY, A. E. The annual cycle of growth rate and biomass change in Planktotrhix spp. in Blelham Tarn, English Lake District. Freshwater Biology, Oxford, v. 48, p. 852-867, 2003.

DENIS, M.; FRÉMY, P. Une nouvelle Cyanophycee heterocystée: Anabaena viguieri. Bull. Soc. linn. Normandie, sér. 7, Caen, v. 7, 1923.

DESIKACHARY, T. V. Cyanophyta. New Delhi, Indian Council of Agricultural Research. 686p. 1959.

DROUET, F. Revision of the classification of the Oscillatoriaceae. Philadelphia: The Academy of Natural Sciences, 1968. 370 p. (Monograph 15).

. The Brazilian Myxophyceae, 2. Am. J. Bot., Lancaster, v. 25, n. 9, p. 657-666, 1938.

Revision of the classification of the Nostocaceae with cylindrical trichomes. New York:. Hafner, 1973. 292p.

Revision of the classification of the Nostocaceae with constricted trichomes. Nova Hedwigia, Weinheim, v.57, p. 1-258, 1978.

Revision of the Stigonemataceae with a summary of the classification of blue-green algae. Nova Hedwigia, Weinheim, v.66, p. 1-221, 1981. 
DROUET, F.; DAILY, W. A. Revision of the coccoid Myxophyceae. Butler University Botanical Studies, Indianopolis. v. 12, p. 1-222, 1956.

DUMANS, A. Biotreatment of fishfarm effluents using the cyanobacteria Phormidium bohneri. Aquacult. Eng., Oxford, v. 7, n. 5, p. 68, 1988.

EHRENBERG, C. G. Die Infusionsthierchen als vollkommene Organismen. v.2. Leipzig: Engelmann, 1838. 612p.

ELENKIN, A. A. Ob osnovnych principach sistemy Cyanophyceae. [About the main principles of the system of Cyanophyceae]. Sov. Bot. v. 4, p. 51-83, 1935.

Monographia algarum cyanophycearum aquis dulcium et terrestrium in finibus URSS inventarum [Sinezelenye vodorosli SSSR], Pars spec. v. 2, n.. 1-2, 1908p., Izd. Na SSSR, Moskva-Leningrad, 1938-1949.

ERHARD, M.; DÖHREN, H.; JUNGBLUT, P. R. Rapid identification of the new anabaenopeptin G from Planktothrix agardhii HUB 011 using matrix-assisted laser desorption/ionization time-of-flight mass spextrometry. Rapid Commun. Mass Spec., v. 13, n. 5, p. 337-343, 1998.

ESTEVES, F. A. Fundamentos de Limnologia. 2.ed. Rio de Janeiro: Interciência, 1998. 602 p.

FALCHINI, L.; SPARVOLI, E.; TOMASELLI, L. 1996. Effect of Nostoc (cyanobacteria) inoculation on the structure and stability of clay soils. Biol. Fertil. Soils, Heidelberg, v. 23, p. 246-252.

FASTNER, J.; ERHARD, M.; CARMICHAEL, W. W.; SUN, F.; RINEHART, K. L.; RÖNICKE, H.; CHORUS, I. Characterization and diversity of microcystins in natural blooms and strains of the genera Microcystis and Planktohrix from German freshwater. Arch. Hydrobiol., Stuttgart, v. 145, n. 2, p. 147-163, 1999.

FONSECA, I.A. and RODRIGUES, L. Cianobactérias perifíticas em dois ambientes lênticos da planície de inundação do alto Rio Paraná, PR, Brasil. Revista Brasil. Bot., São Paulo, v. 28 , n. 4, p. 821-834, 2005.

FRANCESCHINI, I. M. Levantamento das Nostocophyceae do rio Seco, Torres, Rio Grande do Sul, Brasil. 1983. 157 f. Dissertação (Mestrado em Ciências Biológicas Botânica) - Instituto de Biociências, Universidade Federal do Rio Grande do Sul, Porto Alegre.

Flora de Cyanophyceae do Rio Seco, Torres, Rio Grande do Sul, Brasil. Napaea, Porto Alegre, v. 7, p. 1-39, 1990. 
Algues d'eau douce de Porto Alegre, Brésil (les Diatomophycées exclues). Biblioteca Phycologica. J. Cramer (ed.), Berlin - Stuttgart, v. 92, p. 1-82, 1992.

FRÉMY, P. Les Cyanophycées de Côtes d'Éurope. Mém. Soc. natn Sci. nat. Math. Cherbourg. v. 41, p. 1-234, 1929-1933.

Les Myxophycées de l'Afrique équatoriale française. Arch. Bot. Mém., Caen, v. 3, n. 2, p. 1-493, 1930.

GARDNER, N. L. New Myxophyceae from Porto Rico. Mem. N. Y. bot. Gdn., New York, v. 7, p.1-444, 1927.

GARCIA-PICHEL, F.; CASTENHOLZ, R. W. Comparative anoxygenic photosynthetic capacity os seven strains of a thermophilic cyanobacterium. Arch. Microbiol., New York, v. 153, n. 4, p. 344-351, 1990.

GEITLER, L. Cyanophyceae. In: PASCHER'S Süsswasser-Flora. 12. Jena, Gustav FischerVerlag, 450p. 1925.

Cyanophyceae. In: Rabenhorst's Kryptogamenflora von Deutschland, Österreich und der Schweiz. 2. Aufl. Leipzig, Akademische. Verlagsgesellschaft. v. 14, 1196p. 1932.

Schizophyta (Klasse Schizophyceae). In: ENGLER \& PRANTL. Nat. Planzenfam., 1942. v. 1b, 232 p.

GIOVANNONI, S.J.; TURNER, S.; OLSEN, G.J.; BARNS, S.; LANE, D.J. ; PACE, N.R. Evolutionary Relationships among Cyanobacteria and Green Chloroplasts. J. Bacteriol., Washington, v. 170, n. 8, p. 3584-3592, 1988.

GOMONT, M. M. Monographie des Oscillariées (Nostocacées homocystées). Ann. Sci. nat. Bot., sér. 7, Paris, v. 15, p. 263-368; v. 16, p. 91-264; 1892.

GOLD-MORGAN, M., MONTEJANO, G.; KOMÁREK, J. Freshwater epiphytic Chamaesiphonaceae from Central Mexico. Algolog. Studies, Stuttgart, v. 83, p. 257-271. 1996. 
GORHAM, E. 1996. Wetlands: na essential component of curricula in limnology. In: COMMITTEE ON INLAND AQUATIC ECOSYSTEMS; WATER SCIENCE AND TECHNOLOGY BOARD; COMMISSION ON GEOSCIENCES, ENVIRONMENT AND RESOURCES (Eds.). Freshwater Ecosystems: revitalizing educational programs in limnology. Washington: National Academy, p. 234-246.

GRAHAM, L.E. \& WILCOX, L.W. Algae. Upper Saddle River: Prentice Hall, 2000, 700p.

GUARRERA, S. A. Algas de agua dulce nuevas para Argentina - II Cyanophyta de Chubut. Darwiniana, Buenos Aires, v. 2, n. 1, 1977.

GUARERRA, S. A.; ECHENIQUE, R. O.; CASCO, M. A.; LABOLLITA, H. A. Las algas del sistema del rio Limay (Republica Argentina). I- Cyanophyta: 2- Hormogonales (1). Revista Mus. La Plata, Bot., La Plata, v. 34, n. 101, p. 269-305, 1995.

GUARRERA, S. A. et al. Fitoplancton de las aguas superficiales de la provincia de Buenos Aires. I. Area de la pampa deprimida. Rev. Mus. La Plata, Sec. Bot., La Plata, v. 10, n.49, p. 223-331, 1968.

GUGGER, M.F.; HOFFMANN, L. Polyphyly of true branching cyanobacteria (Stigonematales). Int. J. Syst. Evol. Microbiol., London, v. 54, p. 349-357, 2004.

GUGGER, M.; LYRA, C.; HENRIKSEN, P.; COUTÉ, A.; HUMBERT, J. and SIVONEN, K. Phylogenetic comparison of the cyanobacterial genera Anabaena and Aphanizomenon. Inter. J. Syst. Evol. Microbiol., Spencers Wood, v. 52, p. 1867-1880, 2002a.

GUGGER, M.; LYRA, C; SUOMINEM, I.; TSITKO, I.; HUMBERT, J. F.; SALKINOJASALONEN, M.; SIVONEN, K. Cellular fatty acids as chemotaxonomic markers of the genera Anabaena, Aphanizomenon, Microcystis, Nostoc and Planktothrix (Cyanobacteria). Inter. J. Syst. Evol. Microbiol., Spencers Wood, v. 52, p. 1007-1015, 2002 b.

HALSTVEDT, C. B.; ROHRLACK, T.; ANDERSEN, T.; SKULBERG, O.; EDVARDSEN, B. Seasonal dynamics and depth distribution of Planktothrix spp. in Lake Steinsfjorden (Norway) related to environmental factors. J. Plankton Research, Oxford, v. 29, n. 5, p. 471482, 2007.

HAWKINS, P. R. et al. Severe hepatotoxicity caused by the tropical cyanobacterium (bluegreen algae) Cylindrospermopsis raciborskii (Woloszynska) Seenaya and Subba Raju isolated from domestic water supply reservoir. Applied and Environmental Microbiology, Wasington, v. 50, n. 5, p.1292-1295, 1985. 
HINDÁK, F; ZAGORENKO, G. F. Contribution to the knowledge of the species composition of summer phytoplankton of lake Hubsugul, Mongolia. Folia Geobot. Phytotax., Praha, v. 27, p. 419-439, 1992.

HOFFMANN, L.; KOMÁREK, J.; KASTOVSKY, J. System of cyanoprokaryotes (cyanobacteria) - state in 2004. Algolog. Studies, Sttutgart, v. 117, p. 95-115, 2005.

HOICZYK, E.; BAUMEISTER, W. Envelope Structure of Four Gliding Filamentous Cyanobacteria. J. Bacteriol., Washington, v. 177, n. 9, p. 2387-2395, 1995.

HUSZAR, V. L. M.; ESTEVES, F. A. Considerações sobre o fitoplâncton de rede de 14 lagoas costeiras do Estado do Rio de Janeiro, Brasil. Acta Limnol. Brasil., São Carlos, v.2, p. 323-345, 1988.

HUSZAR, V. L. M.; MENEZES, M.; FERNANDES, V. O. Fitoplâncton de rede da Lagoa Cabiúnas, Macaé, Estado do Rio de Janeiro, Brasil: uma contribuição a seu conhecimento. Bolm Mus. nac. Rio de J., Bot., Rio de Janeiro, n. 78, p. 1-43, 1989.

HUSZAR, V. L. M.; SILVA, L. H. S. Comunidades fitoplânctônicas de quatro lagoas costeiras do Norte do Estado do Rio de Janeiro, Brasil. Acta Limnol. Brasil., São Carlos, v. 4, p. 291-314, 1992.

JOOSTEN, A. M. T. Flora of the blue-green algae of the Netherlands - I. the nonfilamentous species of inland waters. Utrecht: KMNV Publishing, 2006. 239p.

KAAS, H. HENRIKSEN, P. Saxitoxins (PSP toxins) in Danish lakes. Wat. Res., Oxford, v. 34, p. 2089-2097, 2000.

KIM, B. C.; KIM, E. K.; PYO, D. J.; PARK, H. D.; HEO, W. M. Toxic cyanobacterial blooms in Korean lakes. J. KSWQ, v. 11, p. 231-237, 1995.

KOMÁREK, J. Die taxonomische Revision der planktischen Blaualgen der Tschechoslowakei. In: KOMÁREK, J.; ETTL, H. (Ed.) Algologische Studien. Praga: Tschechoslowakischen Akademie der Wissenschaften, 1958. 206 p.

A review of water-bloom forming Microcystis species, with regard to population from Japan. Algolog. Studies, Sttutgart, v. 64, p. 115-127, 1991. 
Studies on the Cyanophytes (cyanoprokaryotes) of Cuba 10. New and little known chroococcalean species. Folia Geobot. Phytotax., Praha, v. 30, p. 81-90, 1995.

. Coccoid and colonial Cyanobacteria. In: WEHR, J. D.; SHEATH, R. G. (Ed.) Fresh water algae of North America, Ecology and Classification. San Diego: Academic Press, 2003a, 59-116p.

Problem of the taxonomic category "species" in cyanobacteria. Algol. Studies, Stuttgart, v. 109, p. 281-297, 2003b.

Cyanobacterial Taxonomy: current problems and prospects for the integration of traditional and molecular approaches. Algae, Ceské Budejovice, v. 21, n. 4, p. 349-375, 2006.

Phenotype diversity of the cyanobacterial genus Leptolyngbya in the maritime Antarctic. Pol. Polar Res., Gdansk, v. 28, n. 3, p. 211-231, 2007. 2008.

The cyanobacterial genus Macrospermum. Fottea, Olomouc, v. 8, n. 1, p. 79-86,

KOMÁREK, J.; ANAGNOTIDIS, K. Modern approach to the classification system of cyanphytes 2 - Chroococcales. Arch. Hydrobiol./Suppl. v. 73, n. 2, Algolog. Studies, Sttutgart, v. 43, p. 157-226, 1986.

Modern approach to the classification system of cyanophytes 4 - Nostocales. Arch.

Hydrobiol./Suppl. v. 82, n. 3, Algol. Studies, Stuttgart, v. 56, p. 247-345, 1989.

. Nomenclatural novelties in chroococcalean cyanoprokaryotes. Preslia, Praha, n. 67, p. $15-23,1995$.

KOMÁREK, J.; ANAGNOSTIDIS, K. Cyanoprokaryota 1. Teil: Chroococcales. In: ETTL, H.; GÄRTNER, G.; HEYNIG, H.; MOLLENHAUER, D. (eds.) Süßwasserflora von Mitteleuropa 19/1, Gustav Fischer, Jena-Sttutgart-Lübeck-Ulm, 1998. 548 p.

Cyanoprokaryota 1. Teil: Oscillatoriales. In: BÜDEL, B.; KRIENITZ, L.; GÄRTNER, G; SCHAGERL, M. (Edes.). Süßwasserflora von Mitteleuropa 19/2, Heidelberg: Elsevier/Spektrum Akademischer Verlag, 2005. 759p. 
KOMÁREK, J. \& AZEVEDO, M. T. de P. Geitlerinema unigranulatum, a common tropical cyanoprokaryote from freshwater reservoirs in Brazil. Algol. Studies Stuttgart, v. 99, p. 3952. 2000.

KOMÁREK, J.; CRONBERG, G. Some chroococcalean and oscillatorialean Cyanoprokaryotes from southern African lakes, ponds and pools. Nova Hedwigia, Stuttgart, v. 73, n. 1-2, p. 129-160, 2001.

KOMÁREK J. \& HAUER T. (2009): CyanoDB.cz - On-line database of cyanobacterial genera. - Word-wide electronic publication, Univ. of South Bohemia \& Inst. of Botany AS CR, http://www.cyanodb.cz. Acesso em 06.agosto.2009

KOMÁREK, J.; HINDÁK, F. Taxonomic review of natural populations of cyanophytes from Gomphosphaeria-complex. Arch. Hydrobiol./Suppl. v. 80, n. 1-4, Algol. Studies, Stuttgart, v. 50-53, p. 203-225, 1988.

The genus Eucapsis (Cyanophyta/Cyanobacteria) in Czechoslovakia. Acta hydrobiol, Kraków, v. 31, n. 1/2, p. 25-34, 1989.

KOMÁREK, J. and KASTOVSKY, J. Coincidences of structural and molecular characters in evolutionary lines of cyanobacteria Algol. Studies, Sttutgart, v. 109, n. 4, p. 305-325. 2003.

KOMÁREK, J.; KLING, H. Variation in six planktonic cyanophyte genera in lake Victoria (East Africa). Algolog. Studies, Sttutgart, v. 61, p. 21-45, 1991.

KOMÁREK, J.; KOMÁRKOVÁ, J. Review of the European Microcystis-morphospecies (Cyanoprokariotes) from nature. Czech Phycol., Olomouc, v. 2, p. 1-24, 2002.

Phenotype diversity of the cyanoprokaryotic genus Cylindrospermum (Nostocales): review 2002. Czech Phycol., Olomouc, v. 3, p. 1-30, 2003.

KOMÁREK, J.; KOMÁRKOVÁ, J. Taxonomic review of the cyanoprokaryotic genera Planktothrix and Planktothricoides. Czech Phycol., Olomouc, v. 4, p. 1-18, 2004.

Diversity of Aphanizomenon-like, cyanobacteria. Czech Phycology, Bohemia, v. 6, p.1-32, 2006.

KOMÁREK, J.; KOMÁRKOVÁ-LEGNEROVÁ. Contribution to the knowledge of planktic cyanoprokaryotes from central Mexico. Preslia, Praha, v. 74, p. 207-233, 2002. 
KOMÁREK, J.; KOVÁCIK, L. Trichomes structure of four Aphanizomenon taxa (Cyanophyceae) from Czechoslovakia, with notes on the taxonomy and delimitation of the genus. Pl. Syst. Evol., Suppl., Vienna, n. 164, p. 47-64, 1989.

KOMÁREK, J. ZAPOMELOVÁ, E. Planktic morphospecies of the cyanobacterial genus Anabaena $=$ subg. Dolichospermum -1 . part: coiled types. Fottea, Olomouc, v. 7, n. 1, p. 131, 2007.

Planktic morphospecies of the cyanobacterial genus Anabaena = subg. Dolichospermum - 2. part: straight types. Fottea, Olomouc, v. 8, n. 1, p. 1-14, 2008.

KOMÁRKOVÁ, J.; LAUDARES-SILVA, R.; SENNA, P.A.C. Extreme morphology of Cylindrospermopsis raciborskii (Nostocales, Cyanobacteria) in the lagoa do Peri, a freshwater coastal lagoon, Santa Catarina, Brazil. Algol. Studies, Stuttgart, v. 94, p. 207-222, 1999.

KOMÁRKOVÁ-LEGNEROVÁ. Epigloeosphaera, a new cyanphyte genus from Nordic lake. Algolog. Studies, Sttutgart, v. 62, p. 7-12, 1991.

KOMÁRKOVÁ-LEGNEROVÁ, J.; CRONBERG, G. New and recombined filamentous cyanophytes from lakes in South Scania, Sweden. Algol. Studies, Stuttgart, v. 67, p. 2131, 1992.

Planktic blue-green algae from lakes in South Scania, Sweden. Part I. Chroococcales. Algol. Studies, Stuttgart, v. 72, p. 13-51, 1994.

KOMÁRKOVÁ-LEGNEROVÁ, J.; ELORANTA, P. Planktic blue-green algae (Cyanophyta) from Central Finland (Jyväskylä region) with special reference to the genus Anabaena. Algol. Studies, Stuttgart, v. 67, p. 103-133, 1992.

KOMÁRKOVÁ-LEGNEROVÁ, J.; TAVERA, R. Cyanoprokaryota (Cyanobacteria) in the phytoplankton of lake Catemaco (Vera Cruz, México). Algol. Studies, Stuttgart, v. 83, p. 403-422, 1996.

KOVACH, W.L. MVSP - A multivariate statistical package for Windows, versão 3.0. Pentranh, Wales, United Kingdom: Kovach Computing Services, 1998.

KREITLOW, S.; MUNDT, S.; LINDEQUIST, U. Cyanobacteria - a potential source of new biologically active substances. J. Biotech., v. 70, p. 61-63, 1999.

LEMMERMANN, E. Algen I. Kryptogamenflora, Leipzig, v. 3, p. 1-256, 1907. 
LILLEHEIL, G.; ANDERSEN, R. A.; SKULBERG, O. M.; ALEXANDER, J. Effects of a homoanatoxin-a-containing extract from Oscillatoria Formosa (Cyanophyceae/ Cyanobacteria) on neuromuscular transmission. Toxicon, Oxford, v. 35, n. 8, p. 1275-1289, 1997.

MAGURRAN, A. E. Ecological diversity and its measurement. Princeton: Princeton University Press, 1988. 179p.

McGREGOR, G. B. Freshwater Cyanoprokaryota of North-Eastern Australia. I: Oscillatoriales. Canberra: Goanna Print, 2007, 124p.

MILLER, S. R. Diversity of the cosmopolitan termophile Mastigocladus laminosus at global, regional and local scale. In: SECKBACH, J. (Ed.). Algae and Cyanobacteria in Extreme Environments. Dordrecht: Springer, 2007. cap. 5, p. 401-412.

OREN, A. Diversity of organic osmotic compounds and osmotic adaptation in Cyanobacteria and Algae. In: SECKBACH, J. (Ed.). Algae and Cyanobacteria in Extreme Environments. Dordrecht: Springer, 2007. cap. 6, p. 641-655.

MIYASHITA, H.; IKEMOTO, H.; KURANO, N. ADACHI, K.; CHIHARA, M.; MIYACHI, S. Chlorophyll $d$ as a major pigment. Nature, London, 383: 402, 1996.

MÖBIUS, M. Ueber einige brasilianische Algen. Nova Hedwigia, Weinheim, v. 34, p. 173-180, 1895.

NEHRING, S. Mortality of dogs associated with a mass development of Nodularia spumigena (Cyanophyceae) in a brackish lake at the German North Sea coast. J. Plankton Res., Oxford, v. 13, p. 867-872, 1993.

NIMER, E. Clima. In: IBGE. Geografia do Brasil: região sul. SERGRAF-IBGE, Rio de Janeiro, 1977. p. 35-79.

OLIVEIRA, B. A. D. Contribuição ao estudo taxonômico das cianofíceas heterocitadas continentais do estado do Rio de Janeiro, Brasil. 1976. 104 f. Dissertação (Livre-Docência) Departamento de Botânica do Museu Nacional, Universidade Federal do Rio de Janeiro, Rio de Janeiro.

OLIVEIRA, M. D. de; TRAIN, S.; RODRIGUES, L. C. Levantamento preliminar do fitoplâncton (exceto Zygnemaphyceae) do Rio Paraná, no Município de Porto Rico, Paraná, Brasil. Revista UNIMAR, Maringá, v. 16, p. 155-174, 1994. (Suplemento 3). 
ONODERA, H.; OSHIMA, Y.; HENRIKSEN, P.; YASUMOTO, T. Confirmation of anatoxin-a(s), in the cyanobacterium Anabaena lemmermannii, as the cause of bird kills in Danish lakes. Toxicon, Oxford, v. 35, p. 1645-1648, 1997.

OREN, A. A proposal for further integration of the cyanobacteria under the Bacteriological Code. Int. J. Syst. Evol. Microbiol., London, v. 54, p. 1895-1902, 2004.

OREN, A.; SHILO, M. Anaerobic heterotrophic dark metabolism in the cyanobacterium Oscillatoria limnetica: sulfur respiration and lactate fermentation. Arch. Microbiol., Bimonthly, v. 122, p. 77-84, 1979.

PADAN, E.; COHEN, Y. Anoxygenic photosynthesis. In: CARR, N. G.; WHITTON, B. A. (Ed.) The Biology of Cyanobacteria. Berkeley: University of California Press, 1982. cap. 9, p. 215-235.

PAERL, H. W. Marine plankton. In: WHITTON, B. A.; POTTS, M. (Ed.) The ecology of Cyanobacteria. Their diversity in time and space. Dordrecht: Kluwer Academic, 2000. cap. 5, p. 121-148.

PADISÁK, J. Cylindrospermopsis raciborskii (Woloszynska) Seenayya et Subba Raju, an expanding, highly adaptive cyanobacterium: worldwide distribution and review of its ecology. Arch. Hydrobiol./Suppl. v. 107, Monogr. Stud., Stuttgart, v. 4, p. 563-593, 1997.

PANDI, M.; SHASHIREKHA, V. C.; SWAMY, M. Bioabsorption of chromium from reton chrome liquor by cyanobacteria. Microbiol. Res., Amsterdam, v. 164, p. 420-428, 2009.

PERES, C. K. Macroalgas de ambientes lóticos da Serra da Prata, leste do estado do Paraná: flora, distribuição ambiental e dinâmica temporal. 2007. 77f. Dissertação (Mestrado em Ciências Biológicas - Botânica) - Universidade Federal do Paraná, Curitiba.

PÉREZ, M. C.; MAIDANA, N. I.; COMAS, A. Phytoplankton composition of the Ebro River estuary, Spain. Acta Bot. Croat., Zagreb, v. 68, n. 1, p. 11-27, 2009.

PRESCOTT, G. W. Algae of the western Great Lake área; with na illustrates key to the genera of desmids and freshwater diatoms. 4 ed. Dubuque, Iowa: W.M.C. Broun, 1970. 977p.

RABENHORST, L. Flora europaea algarum: algae aquaedulcis et submarine. sect. 2, 319p. 1865 . 
RAJANIEMI, P.; HROUZEK, P.; KASTOVSKÁ, K.; WILLAME, R.; RANTALA, A.; HOFFMANN, L. KOMÁREK, J. and SIVONEN, K. Phylogenetic and morphological evaluation of the genera Anabaena, Aphanizomenon, Trichormus and Nostoc (Nostocales, Cyanobacteria). Inter. J. Syst. Evol. Microbiol., London, v. 55, p. 11-26, 2005a.

RAJANIEMI, P.; KOMÁREK, J.; WILLAME, R.; HROUZEK, P.; KASTOVSKÁ, K.; HOFFMANN, L. and SIVONEN, K. Taxonomic consequences from the combined molecular and phenotype evaluation of selected Anabaena and Aphanizomenon strains. Algol. Studies, Stuttgart, v. 117, p. 371-391, 2005 b.

RAMOS, R. A.; PASQUALETTO, A. I.; BALBUENO, R. A.; PINHEIRO, E. S. Paisagem, uso e cobertura da terra. In: BECKER, F. G.; RAMOS, R. A.; MOURA, L. A. Biodiversidade do Rio Grande do Sul: regiões da lagoa do Casamento e dos Butiazais de Tapes, planície costeira do Rio Grande do Sul. Brasília, 2007. Cap. 5, p. 60-83.

RAVEN, J. A.; ALLEN, J. F. Genomics and chloroplast evolution: what did cyanobacteria do for plants? Gen. Biol., Dundee, v. 4, n. 3, (article 209), 2003.

ROSA, Z. M. et al. Ficoflora de ambientes lênticos - estudo preliminar da região de Charqueadas, Rio Grande do Sul, Brasil, com vistas à avaliação ambiental. Acta bot. bras. Porto Alegre, v. 1, n. 2, p. 165-188, 1987.

SAKER, M. L.; NEILAN, B. A.; GRIFFITHS, D. Two morphological forms of Cylindrospermopsis raciborskii (Cyanobacteria) isolated from Solomon Dam, Palm Island, Queensland. J. Phycol., San Marcos, v. 35, p. 599-606, 1999.

SANT'ANNA, C. L. Flora de Cyanophyceae associada a briófitas, Município de Campina Verde, MG. Rickia, São Paulo, n. 11, p. 129-142, 1984.

. Scytonemataceae (Cyanophyceae) from the state of São Paulo, southern Brazil. Nova Hedwigia, Stuttgart, v. 46, n. 3-4, p. 519-539, 1988.

Two new taxa of Anabaena and other Nostocaceae from São Paulo State, Southeastern Brazil. Algol. Studies, Stuttgart, v. 64, p.527-545, 1991.

Cyanophyceae/Cyanobacteria diversity in Brazil. In: BiCudo, C.E.M. \& MENEZES, N.A. Biodiversity in Brazil: a first approach. São Paulo: CNPq, 1996, cap. 1, p. 1-4.

Cyanophyceae marinhas bentônicas da região de Ubatuba, SP, Brasil. Hoehnea, São Paulo, v. 24, n. 2, p. 57-74, 1997. 
SANT'ANNA, C. L.; AZEVEDO, M. T. P. Oscillatoriaceae (Cyanophyceae) from São Paulo State, Brazil. Nova Hedwigia, Stuttgart, v. 60, n. 1-2, p. 19-58, 1995.

SANT'ANNA, C.L.; AZEVEDO, M.T.P.; SENNA, P.A.C.; KOMÁREK, J. and KOMÁR'KOVÁ, J. Planktic Cyanobacteria from São Paulo State, Brazil: Chroococcales. Revista Brasil. Bot., São Paulo, v. 27, n. 2, p. 213-227, 2004.

SANT'ANNA, C. L.; AZEVEDO, M. T. P.; SORMUS, L. Fitoplâncton do lago das Garças, Parque Estadual das Fontes do Ipiranga, São Paulo, SP, Brasil: estudo taxonômico e aspectos ecológicos. Hoehnea, São Paulo, v. 16, p. 89-131, 1989

SANT'ANNA, C. L.; BICUDO, R. M. T.; PEREIRA, H. A. S. L. Nostocophyceae (Cyanophyceae) do Parque Estadual da Ilha do Cardoso, Estado de São Paulo, Brasil. Rickia, São Paulo, n. 10, p. 1-27, 1983.

SANT'ANNA, C. L.; PEREIRA, H. A. S. L.; BICUDO, R. M. T. Contribuição ao conhecimento das Cyanophyceae da Parque Estadual das Fontes do Ipiranga, São Paulo, Brasil. Revta bras. Biol., Rio de Janeiro, v. 38, n. 2, p. 321-337, 1978.

SANT'ANNA, C. L.; SILVA, S. M. F.; BRANCO, L. H. Z. Cyanophyceae da Gruta-queChora, Município de Ubatuba, Estado de São Paulo, Brasil. Hoehnea, São Paulo, n. 18, v. 2, p. 75-97, 1991.

SANT'ANNA, C. L. et al. Cianofíceas marinhas bentônicas das praias de Peruíbe e dos Sonhos, município de Itanhaén, SP, Brasil, 1. Rickia, São Paulo, n. 12, p. 89-112, 1985.

SANT'ANNA et al. Cianofíceas marinhas bentônicas das praias de Peruíbe e dos Sonhos, Município de Itanhaém, SP, Brasil, III. Revta bras. Biol., Rio de Janeiro, v. 55, n. 3, p. 389407, 1995.

SCHOPF, J. W. The Fossil Record: Tracing the Roots of the Cyanobacterial Lineage. In: WHITTON, B. A.; POTTS, M. (Ed.) The ecology of Cyanobacteria. Their diversity in time and space. Dordrecht: Kluwer Academic, 2000. cap. 2, p. 13-35.

SCHOPF, J. W.; WALTER, M. R. Origin and early evolution of Cyanobacteria: The geological evidence. In: CARR, N. G.; WHITTON, B. A. (Ed.) The Biology of Cyanobacteria. Berkeley: University of California Press, 1982. cap. 21, p. 543-670. 
SENNA, P. A. C. Cyanophyceae da lagoa de estabilização de São Carlos, Estado de São Paulo, Brasil. 1979. 116 f. Dissertação (Mestrado em Botânica) - Instituto de Biociências, Universidade de São Paulo, São Paulo.

Nostocophyceae do município de São Paulo, Estado de São Paulo, Brasil. 1982. 249 f. Tese (Doutorado em Ciências) - Instituto de Biociências, Universidade de São Paulo, São Paulo.

SENNA, P. A. C. Nostocophyceae (Cyanophyceae) da represa do Descoberto, Distrito Federal. Brasil. Revta bras. Biol., Rio de Janeiro, v. 48, n. 4, p. 683-696, 1988.

Estudo das Nostocophyceae (Cyanophyceae) do Distrito Federal: lagoas Joaquim Medeiros e dos Carás, 2. Revta bras. Biol., Rio de Janeiro, v. 52, n. 3, p. 461-479, 1992.

Cyanophyceae from the eastern region of Distrito Federal, Brazil, 2. Bull. Jard. Bot. Natl. Belgique, Bruxelles, v. 65, p. 73-102. 1996.

SENNA, P. A. C.; FERREIRA, L. V. Nostocophyceae (Cyanophyceae) da Fazenda Água Limpa, Distrito Federal, Brasil, I - Famílias Chroococcaceae e Oscillatoriaceae. Rev. bras. Bot., São Paulo, v. 9, p. 91-108, 1986.

SENNA, P. A. C.; PERES, A. C.; KOMÁREK, J. Coelomoron tropicalis, a new cyanoprokaryotic species from São Paulo State, Brazil. Nova Hedwigia, Stuttgart, v. 67, n. 1-2, p. 93-100, 1998.

SHASHIREKHA, V.; PANDI, M.; MAHADESWARA, S. Bioremediation of tannery effluents and chromium containing wastes using cyanobacteiral species. JALCA, v. 100, n. 11, p. 419-426, 2005.

SILVA, S. M. F.; SANT'ANNA, C. L. Stigonemataceae (Cyanophyceae) do estado de São Paulo, Brasil: gênero Stigonema Bornet et Flahault. Hoehnea, São Paulo, v. 23, n. 2, p. 33-58, 1996.

SIVONEN, K.; JONES, G. Cyanobacterial toxins. In: CHORUS, I.; BARTRAM, J. Toxic cyanobacteria in water, a guide to public health consequences, monitoring and management. London: E \& FN Spon, 1999. cap. 3, p. 41-112.

SKUJA, H. Grundzüge der Algenflora und Algenvegetation der Fjeldgegenden um Abisko in Schwedisch-Lappland. Nova Acta r. Soc. Sci. upsal., Uppsala, v. 18, n. 3, p.1-465, 1964. 
STANIER, R. Y.; SISTROM, W. R.; HANSEN, T. A. WHITTION, B. A.; CASTENHOLZ, R. W.; WHITTENBURY, R.; GHERNA, R. L.; TRÜPER, H. G. Proposal to place the nomenclature of the cyanobacteria (blue-green algae) under the rules of the International Code of Nomenclature of Bacteria. Int. J. Syst. Bacteriol., Washington, v. 28, p. 335-336, 1978.

STARMARCH, K. Cyanophyta - sinice, Glaucophyta - glaukofity. Flora slodkow. Polski, Pwn Warszawa. v. 2, p. 1-808. 1966.

STEFANIAK, K.; KOKOCINSKI, M.; MESSYASZ, B. Dynamics of Planktothrix agardhii (Gom.) Anagn. et Kom. blooms in polimictic lake Laskownicki and Grylewskie (Wielkopolska region) Poland. Oceanol. Hydrobiol. Studies, Gdansk, v. 34, n. 3, p. 125-136, 2005.

STRӨM, K. M. Algological notes V-IX. Nytt Mag. Naturv., Kristiania, v. 61, p. 127-138, 1923.

THOMASSON, K. Amazonian algae. Mém. Inst. colon. Belge Sci. nat., Sér. 10, Bruxelles, v. 86, n. 1, p. 1-57, 1971.

THURET. G. Essai de classification des Nostochinées. Ann. Sci. nat. Bot., Paris, v. 1, sér. 6, p. 372-382, 1875.

TOMAZELLI, L. J.; DILLENBURG, S.R.; VILLWOCK, J. A. Late Quaternary geological history of Rio Grande do Sul coastal plain, southern Brazil. Revista Brasileira de Geociências, São Paulo, v. 30, n. 3, p.

474-476. 2000.

TOMAZELLI, L. J.; VILWOCK, J. A. O Cenozóico no Rio Grande do Sul: Geologia da Planície Costeira. In: HOLZ, M.; De ROS, L. F. Geologia do Rio Grande do Sul. Porto Alegre, SIGO/UFRGS, 2000. Cap. 13, p. 375-406. (o livro não tem numero de capítulos)

TORGAN, L. C. Estrutura e dinâmica da comunidade fitoplanctônica na laguna dos Patos, Rio Grande do Sul, Brasil, em um ciclo anual. 1997. 284 f. Tese (Doutorado em Ciências Biológicas-Ecologia e Recursos Naturais) - Centro de Ciências Biológicas e da Saúde, Universidade Federal de São Carlos, São Carlos.

TORGAN, L. C.; BUSELATO, T. C.; FERRAZ, G. C. Floração de Aphanizomenon flos-aque (L.) Ralfs ex Born. et Flah. (Cyanophyceae) na represa de Itaúba, Rio Grande do Sul, Brasil. Iheringia, sér. Bot., Porto Alegre, n. 26, p. 45-64, 1981. 
TORGAN, L. C.; PAULA, M. C. F. de. Geitlerinema amphibium (Ag. ex Gom.) Anagn. (Cyanophyta-Pseudanabaenaceae) em um lago no sul do Brasil. Iheringia, sér. Bot., Porto Alegre, n. 45, p. 75-87, 1994.

TUCCI, A.; SANT'ANNA, C. L.; GENTIL, R. C.; AZEVEDO, M. T. P. Fitoplâncton do lago das Garças, São Paulo, Brasil: um reservatório urbano eutrófico. Hoehnea, São Paulo, v. 33, n. 2, p. 147-175, 2006.

TURNER, S. Molecular systematics of oxygenic photosynthetic bacteria. Plant. Syst. Evol., Vienna, v. 11, p. 13-52, 1997.

UHERKOVICH, G. Algen aus einigen Gewässern Amazoniens. Amazoniana, Kiel, v. 7, n. 2, p. 191-219, 1981.

URBACH, E.; ROBERTSON, D.; CHISHOLM, S. W. Multiple evolutionary origins of prochlorophytes within the cyanobacterial radiation. Nature, v. 355, p. 267-270, 1992.

VanGOOR, A. C. J. Zur Kenntnis der Oscillatoriaceen. Recl Trav. bot. néerl, Gronique, v. 15, p. 254-262. 1918.

VASCONCELOS, V. M. Cyanobacterial toxins in Portugal: effects on aquatic animals and risk for human health. Braz. J. Med. Biol. Res., Ribeirão Preto, v. 32, p. 249-254, 1999.

VEZIE, C.; BRIENT, L.; SIVONEN, K.; BETRU, G.; LEFEUVER, J. C.; SALKINOJASALONEN, M. Occurrence of microcystins containing cyanobacterial blooms in freshwaters of Brittany (France). Arch. Hydrobiol., Stuttgart, v. 139, p. 401-413, 1997.

VIEIRA, J. M. S.; AZEVEDO, M. T. P.; AZEVEDO, S. M. F. O.; HONDA, R. Y.; CORREAA, B. Microcystin production by Radiocystis fernandoi (Chroococcales, Cyanobacteria) isolated from a drinking water reservoir in the city of Belém, PA, Brazilian Amazonia region. Toxicon, Oxford, v. 42, n. 7, p. 709-713, 2003.

VILLWOCK, J. A.; TOMAZELLI, L. J. Planície Costeira do Rio Grande do Sul: gênese e paisagem atual. In: BECKER, F. G.; RAMOS, R. A.; MOURA, L. A. Biodiversidade do Rio Grande do Sul: regiões da lagoa do Casamento e dos Butiazais de Tapes, planície costeira do Rio Grande do Sul. Brasília, Distrito Federal. 2007. Cap. 2, p. 20-33.

VILLWOCK, J. A.; TOMAZELLI, L. J.; LOSS, E. L.; DEHNARDT, E. A.; HORN, N. O.; BACHI, F. A.; DEHNARDT, B. A. Geology of the Rio Grande do Sul Coastal Province. In: 
RABASSA, J. Quaternary of South America and Antartic Peninsula. A.A.Balkema, Rotterdan. 1986. Cap. 2, p. 79-97.

VONSHAK, A.; TOMASELLI, L. Arthrospira (Spirulina): Systematics and Ecophysiology. In: WHITTON, B. A.; POTTS, M. (Ed.) The ecology of Cyanobacteria. Their diversity in time and space. Dordrecht: Kluwer Academic, 2000. cap. 18, p. 505-522.

WACKLIN, P.; HOFFMANN, L.; KOMÁREK, J. Nomenclatural validation of the genetically revised cyanobacterial genus Dolichospermum (Ralfs ex Bornet et Flahault) comb. nova. Fottea, Olomouc, v. 9, n. 1, p. 59-64, 2009.

WAECHTER, J. L. Aspectos ecológicos da vegetação de restinga no Rio Grande do Sul, Brasil. Comum. Mus. Ciênc. PUCRS, Sér. Bot., Porto Alegre, v. 33, p. 49-68. 1985.

WATANABE, M. Studies on planktonic blue-green algae 4. Some Anabaena species with straight trichomes in Japan. Bull. natn. Sci. Mus., Ser. B (Botany), Tokyo, v. 18, n.4, p. 123137, 1992.

WATANABE, I; ITO, R.; KONISHI, C. Effects of nitrogen-fixing blue-green algae on the growth of rice plants. Nature, London, v. 168, p. 748-749. 1951.

WATANABE, M.; KOMÁREK, J. Bleu-green algae from Kathmandu. Cryptog. Himalayas, Tsukuba, v. 1, p. 1-20, 1988.

WERNER, V. R. Cyanophyceae (=Nostocophyceae) planctônicas da Lagoa de Tramandaí e da Lagoa do Armazém, Rio Grande do Sul, Brasil: contribuição à taxonomia. 1984. 118 f. Dissertação (Mestrado em Ciências Biológicas - Botânica) - Instituto de Biociências, Universidade Federal do Rio Grande do Sul, Porto Alegre.

Cianofíceae planctônicas da Lagoa de Tramandaí e da Lagoa do Armazém, Rio Grande do Sul, Brasil. Iheringia, sér. Bot., Porto Alegre, n. 37, p. 33-70, 1988.

Cyanophyceae/Cyanobacteria no sistema de lagoas e lagunas da planície costeira do estado do Rio Grande do Sul, Brasil. 2002. 363 f. Tese (Doutorado em Ciências Biológicas-Biologia Vegetal) - Instituto de Biociências, Universidade Estadual Paulista "Júlio de Mesquita Filho", Rio Claro.

WERNER, V. R.; ROSA, Z. M. Cyanophyceae da Estação ecológica do Taim, Rio Grande do Sul, Brasil. Revta bras. Biol., Rio de Janeiro, v. 52, n. 3, p. 481-502, 1992. 
WERNER, V. R.; SANT'ANNA, C. L. Morphological variability in Gloeotrichia natans Rabenhorst ex Bornet et Flahault (Cyanophyceae, Nostocales) from southern Brazil. Revta bras. Biol., Rio de Janeiro v. 58, n. 1, p. 79-84, 1998.

A new species of Aphanothece (Cyanophyceae, Chroococcales) from a shallow coastal lagoon, south Brazil. Nova Hedwigia, Stuttgart v. 70, n. 1-2, p. 113-125. 2000.

Ocurrence of the rare genus Microcrocis P. Richter (Chroococcales, cyanobacteria) in a coastal lagoon from southern Brazil. Revista Brasil. Bot., São Paulo, v. 29, n. 1, p. 183186, 2006.

WESCHENFELDER, J.; CORRÊA, I.C.S. and ALIOTA, S. Elementos arquiteturais do substrato da Lagoa dos Patos revelados por sísmica de alta resolução. Pesquisas em Geociências, Porto Alegre, v. 32, n. 2, p. 57-67. 2005.

WHITTAKER, R. H. Evolution and measurement of species diversity. Taxon, Vienna, v. 21, p. 213-251, 1972.

WHITTON, B. A. Soils and Rice-fields. In WHITTON, B. A.; POTTS, M. (Ed.) The ecology of Cyanobacteria. Their diversity in time and space. Dordrecht: Kluwer Academic, 2000. cap. 8, p. 233-255.

WHITTON, B. A.; POTTS, M. The ecology of Cyanobacteria. Their diversity in time and space. Dordrecht: Kluwer Academic, 2000a. 669p.

WHITTON, B. A.; POTTS, M. Introduction to the Cyanobacteria. In: (Ed.) The ecology of Cyanobacteria. Their diversity in time and space. Dordrecht: Kluwer Academic, 2000b. cap. 1, p. 1-11.

WILlAME, R.; BOUTTE, C.; GRUBISIC, S.; WILMOTTE, A; KOMÁREK, J.; HOFFMANN, L. Morphological and molecular characterization of planktonic cyanobacteria from Belgium and Luxembourg. J. Phycol., San Marcos, v. 42, p. 1312-1332, 2006.

WILMOTTE, A. Molecular Evolution and Taxonomy of the Cyanobacteria. In BRYANT, D. A. (Ed.). The Molecular Biology of Cyanobacteria. London: Kluwer Academic Publishers.1994. cap. 1, p.1-25.

WILMOTTE, A.; GOLUBIC,S. Morphological and genetic criteria in the taxonomy of Cyanobaphyta/Cyanobacteria. Arch. Hydrobiol./Algol. Studies, Stuttagart, v. 64, p. 1-24, 1991. 
YACUBSON, S. Algas de ambientes acuaticos continentals, nuevas para Venezuela (Cyanophyta; Chlorophyta). Boletin del Centro de Investigaciones biologicas, Maracaibo, n. 3, p. 1-87, 1969.

YÉPRÉMIAN, C.; GUGGER, M.F.; BRIAND, E.; CATHERINE, A.; BERGER, C.; QUIBLIER, C.; BERNARD, C. Microcystin ecotypes in a perennial Planktothrix agardhii bloom. Water Research, Oxford, v. 45, n. 19, p. 4446-4456, 2007.

YUAN, M., CARMICHAEL, W.W.; HILBORN, E.D. Microcystin analysis in human sera and liver from human fatalities in Caruaru, Brazil 1996. Toxicon, Oxford, v. 48, p. 627 - 640, 2006.

YUNES, J. S. et al. Toxic blooms of Cyanobacteria in the Patos lagoon estuary. Journal of Aquatic Ecosystem Health., v. 5, p. 223-229, 1996.

YUNES, J. S. et al. Microcystis aeruginosa growth stages and the occurrence of microcystins in Patos Lagoon, southern Brazil. In: REGUERA, B., et al.. Harmful Algae. p. 18-21. Xunta de Galicia and Intergovernmental Oceanografic Comission of UNESCO. 1998.

ZAPOMELOVÁ, E.; HISEM, D.; KOHÁKOVÁ, K.; HROUZEK, P.; JEZBEROVA, J.; KOMÁRKOVÁ, J. KORELUSOVA, J.; ZNACHOR, P. 2008. Experimental comparison of phenotypical plasticity and growth demands of two strains from the Anabaena circinalis/A. crassa complex (cyanobacteria). J. Plankton Research, Oxford, v. 30, n. 11, p. 1257-1269, 2008.

ZAR, J. H. Biostatistical analysis. Upper Saddle River: Prentice-Hall, 1996. 662p. 


\section{ÍNDICE ALFABÉTICO DOS TÁXONS ESPECÍFICOS IDENTIFICADOS}

Anabaena inaequalis (Kützing) Bornet et Flahault............................................................... 157

A. oscillarioides Bory ex Bornet et Flahault ...................................................................... 158

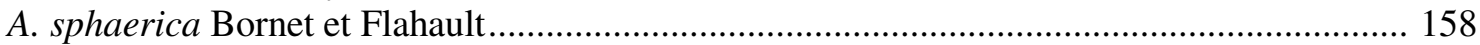

Aphanocapsa conferta (W. et G. S. West) Komárková-Legnerová ......................................... 50

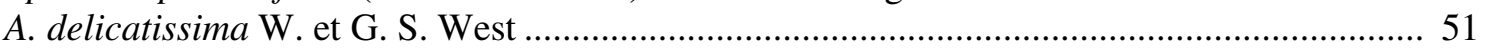

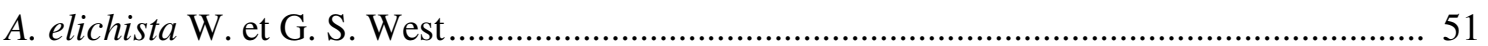

A. holsatica (Lermmermann) Cronberg et Komárek..................................................................... 52

A. incerta (Lemmermann) Cronberg et Komárek ................................................................... 52

A. cf. incerta (Lemmermann) Cronberg et Komárek .................................................................. 53

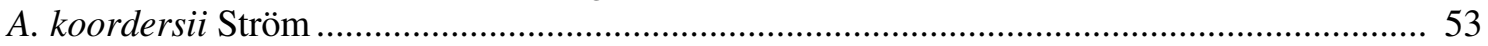

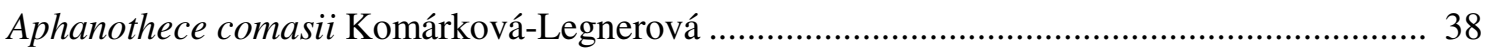

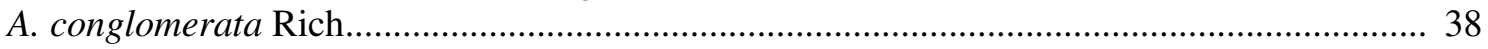

A. minutissima (W. West) Komárková-Legnerová et Cronberg ............................................... 39

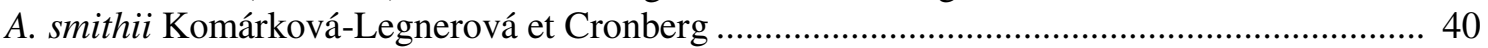

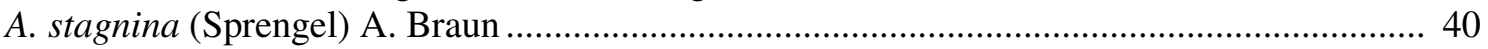

Aulosira laxa Kirchner ex Bornet et Flahault....................................................................... 172

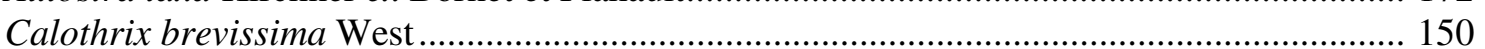

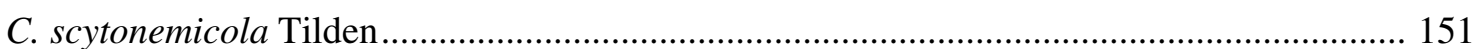

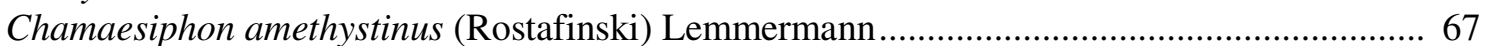

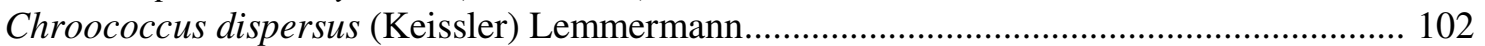

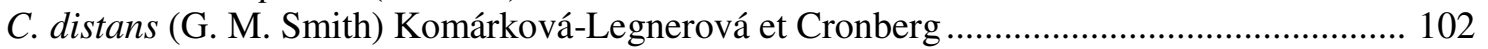

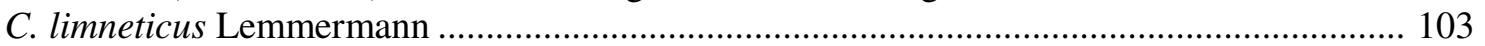

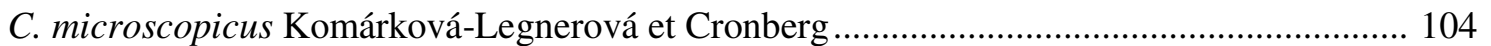

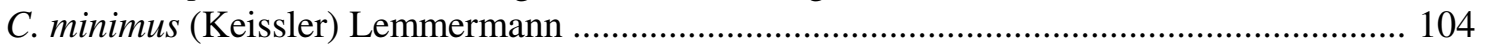

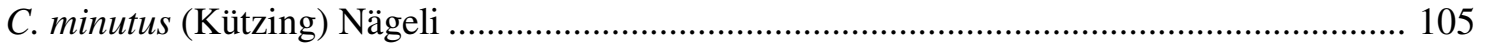

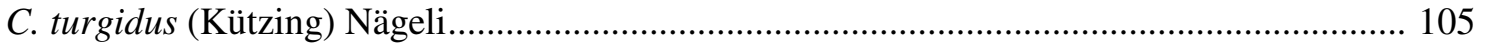

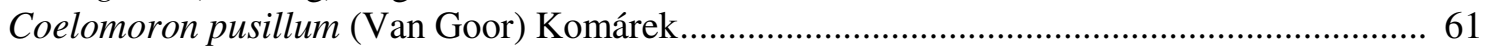

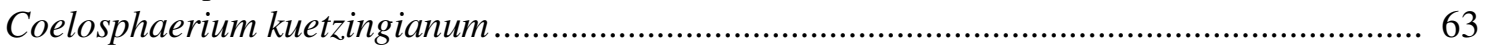

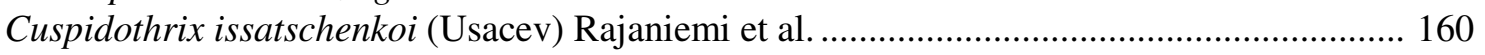

Cyanodictyon reticulatum (Lemmermann) Geitler ...................................................................... 43

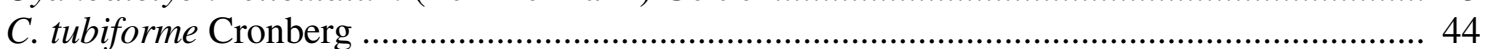

Cylindrospermopsis raciborskii (Wolosynska) Seenayya et Subba Raju ................................ 161

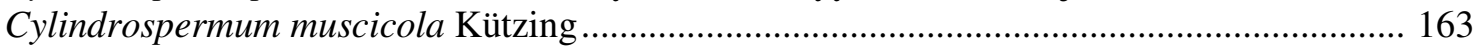

Dolichospermum crassum (Lemmermann) Wacklin et al...................................................... 164

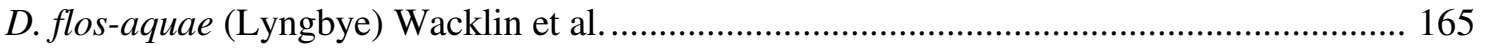

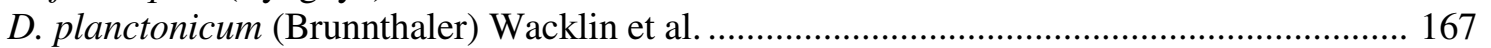

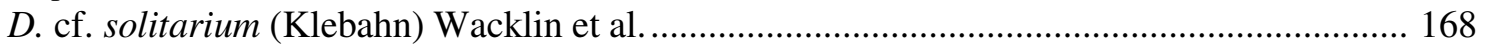

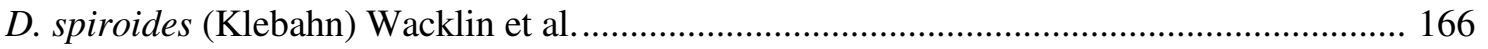

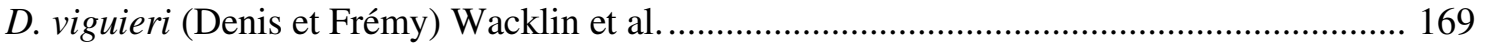

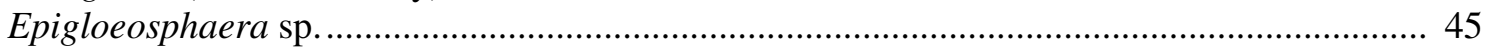

Eucapsis parallelepipedon (Schmidle) Komárek et Hindák ......................................................... 94

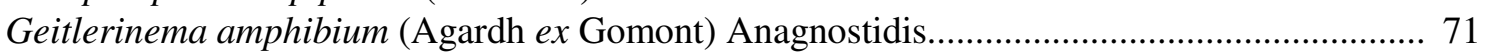

G. splendidum (Greville ex Gomont) Anagnostidis ............................................................. 72

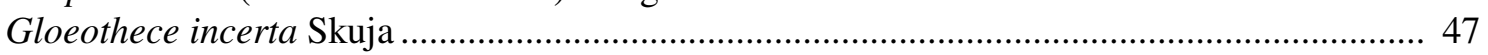

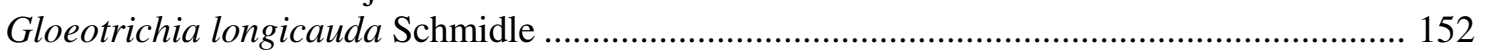

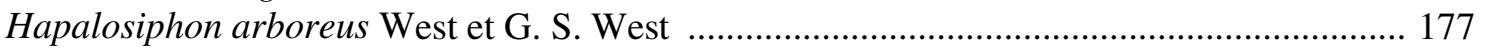

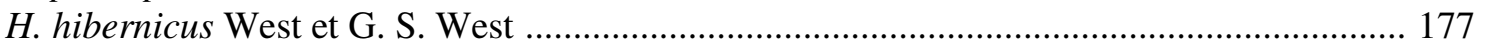




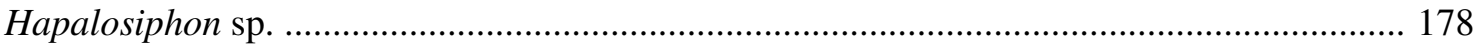

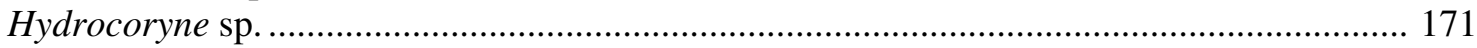

Leptolyngbya cebennensis (Gomont) Umezaki et M. Watanabe ............................................. 75

L. lagerheimii (Gomont) Anagnostidis et Komárek................................................................. 75

L. perelegans (Lemmermann) Anagnostidis et Komárek …….................................................. 76

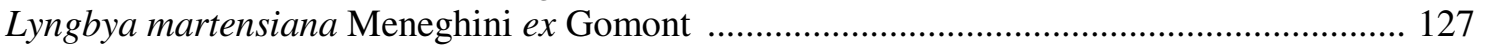

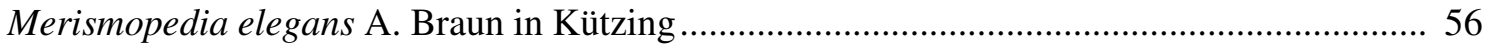

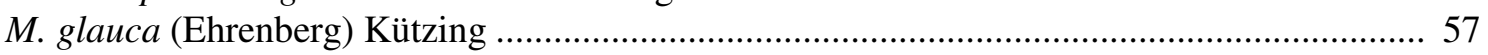

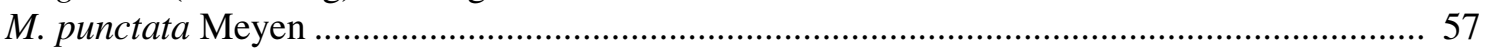

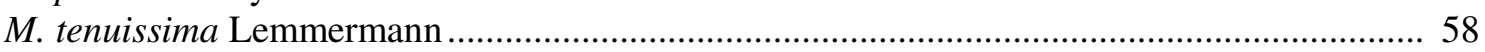

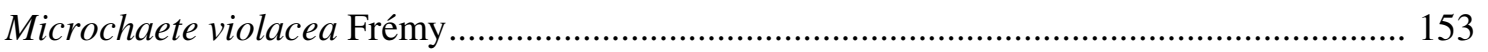

Microcoleus lacustris (Rabenhorst) Farlow ex Gomont ........................................................ 110

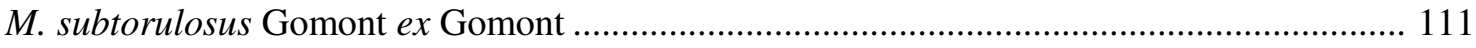

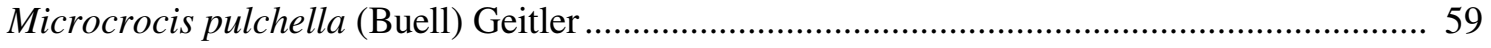

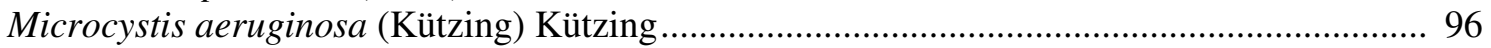

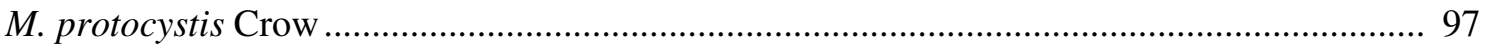

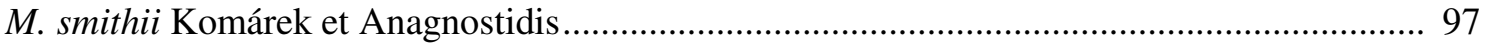

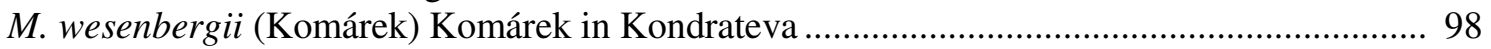

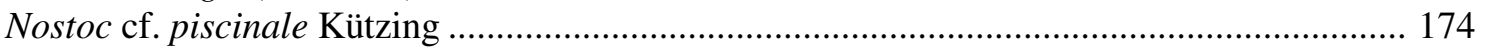

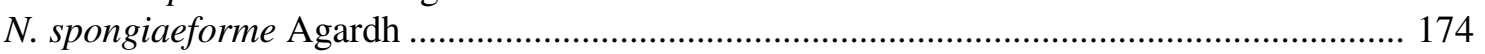

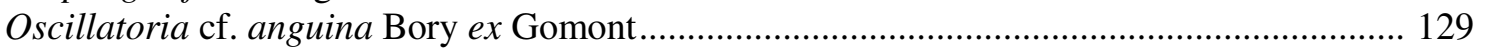

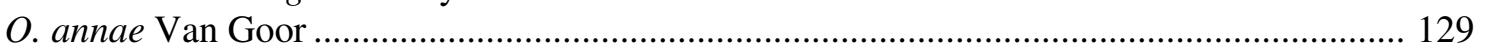

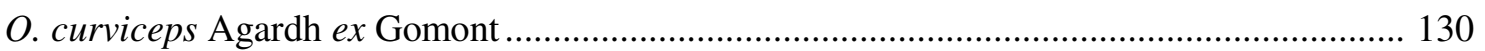

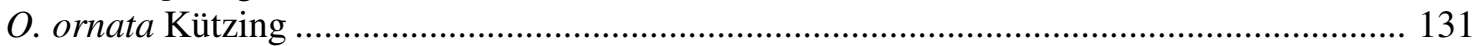

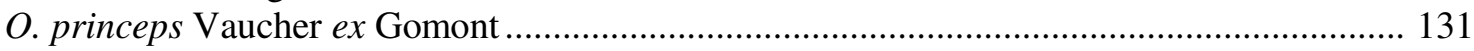

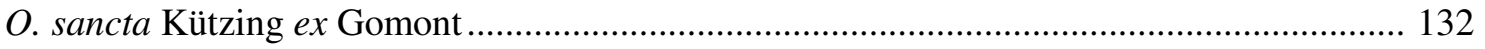

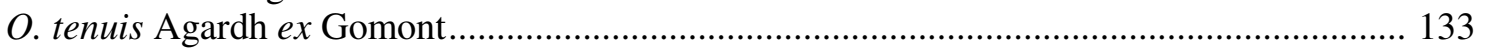

Phormidium aerugineo-caeruleum (Gomont) Anagnostidis et Komárek ................................ 115

P. amoenum Kützing ex Anagnostidis et Komárek................................................................ 115

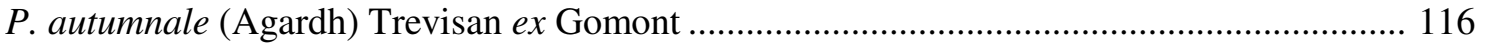

P. chalybeum (Mertens ex Gomont) Anagnostidis et Komárek ............................................... 117

P. formosum (Bory ex Gomont) Anagnostidis et Komárek ..................................................... 117

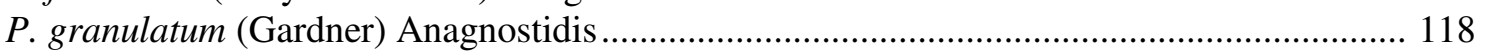

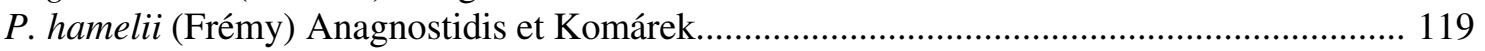

P. tergestinum (Kützing) Anagnostidis et Komárek ................................................................ 119

Planktolyngbya contorta (Lemmermann) Anagnostidis et Komárek ........................................ 78

P. limnetica (Lemmermann) Komárková-Legnerová et Cronberg ......................................... 79

Planktothrix agardhii (Gomont) Anagnostidis et Komárek...................................................... 123

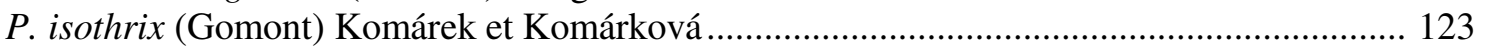

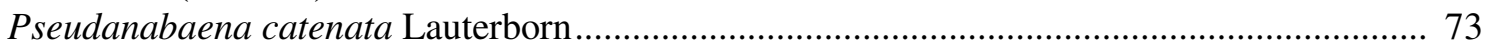

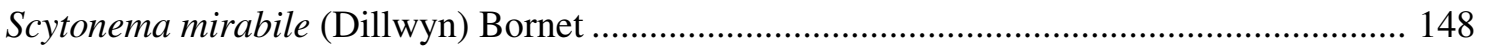

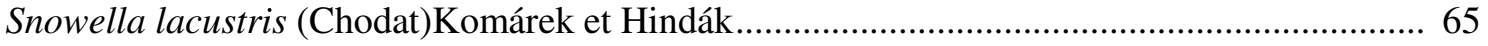

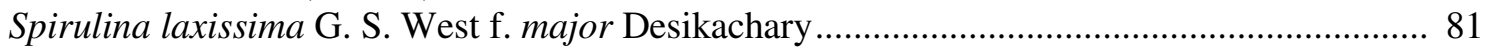

Stigonema ocellatum (Dillwyn) Thuret ex Bornet et Flahault ................................................ 181

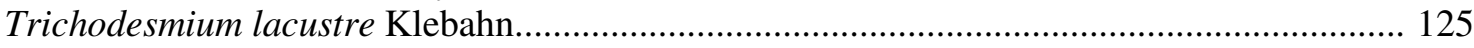

